\title{
Synthesis of five- and six-membered cyclic organic peroxides: Key transformations into peroxide ring-retaining products
}

\author{
Alexander O. Terent'ev ${ }^{* 1, \S}$, Dmitry A. Borisov ${ }^{1}$, Vera A. Vil' ${ }^{1}$ \\ and Valery M. Dembitsky ${ }^{1,2}$
}

\author{
Review \\ Address: \\ ${ }^{1} \mathrm{~N}$. D. Zelinsky Institute of Organic Chemistry, Russian Academy of \\ Sciences, Leninsky Prospect 47, Moscow, 119991, Russia and \\ ${ }^{2}$ Institute for Drug Research, P.O. Box 12065, Hebrew University, \\ Jerusalem 91120, Israel \\ Email: \\ Alexander O. Terent'ev* - alterex@yandex.ru \\ * Corresponding author \\ $\S$ Tel +7-916-385-4080 \\ Keywords: \\ cyclic peroxides; 1,2-dioxanes; 1,2-dioxenes; 1,2-dioxolanes; \\ ozonides; 1,2,4,5-tetraoxanes; 1,2,4-trioxanes; 1,2,4-trioxolanes
}

\author{
Beilstein J. Org. Chem. 2014, 10, 34-114. \\ doi:10.3762/bjoc.10.6 \\ Received: 17 August 2013 \\ Accepted: 16 November 2013 \\ Published: 08 January 2014 \\ Associate Editor: T. P. Yoon \\ () 2014 Terent'ev et al; licensee Beilstein-Institut. \\ License and terms: see end of document.
}

\begin{abstract}
The present review describes the current status of synthetic five and six-membered cyclic peroxides such as 1,2-dioxolanes, 1,2,4trioxolanes (ozonides), 1,2-dioxanes, 1,2-dioxenes, 1,2,4-trioxanes, and 1,2,4,5-tetraoxanes. The literature from 2000 onwards is surveyed to provide an update on synthesis of cyclic peroxides. The indicated period of time is, on the whole, characterized by the development of new efficient and scale-up methods for the preparation of these cyclic compounds. It was shown that cyclic peroxides remain unchanged throughout the course of a wide range of fundamental organic reactions. Due to these properties, the molecular structures can be greatly modified to give peroxide ring-retaining products. The chemistry of cyclic peroxides has attracted considerable attention, because these compounds are used in medicine for the design of antimalarial, antihelminthic, and antitumor agents.
\end{abstract}

\section{Introduction}

Approaches to the synthesis of five and six-membered cyclic peroxides, such as 1,2-dioxolanes I, 1,2,4-trioxolanes (ozonides) II, 1,2-dioxanes III, 1,2-dioxenes IV, 1,2,4-trioxanes $\mathbf{V}$, and 1,2,4,5-tetraoxanes VI, published from 2000 to present are reviewed. These compounds are widely used in synthetic and medicinal chemistry (Figure 1).
In the last decade, two reviews on this rapidly progressing field were published by McCullough and Nojima [1] and Korshin and Bachi [2] covering earlier studies. There are several review articles on medicinal chemistry of peroxides, where the problems of their synthesis are briefly considered. In addition to these reviews other publications dealing with this subject 


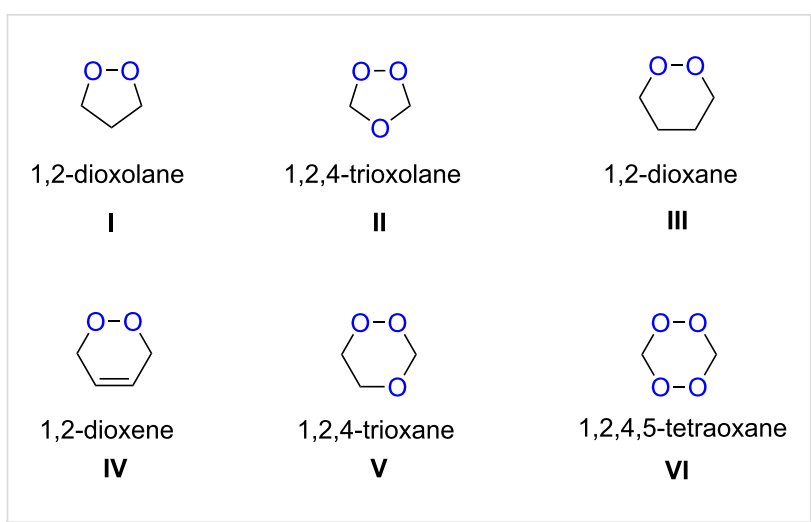

Figure 1: Five and six-membered cyclic peroxides.

appeared: Tang et al. [3], O'Neill, Posner and colleagues [4,5], Masuyama et al. [6], Van Ornum et al. [7], Jefford [8,9], Dembitsky et al. [10-15], Opsenica and Šolaja [16], Muraleedharan and Avery [17], and other [18-27] including dissertations [28-32].

Reviews published earlier on the chemistry of ozone [33-36] and on the chemistry and biological activity of natural peroxides, and cyclic peroxides [37-46] are closely related to this review. Generally speaking, state-of-the-art approaches to the synthesis of cyclic peroxides are based on three key reagents: oxygen, ozone, and hydrogen peroxide. These reagents and their derivatives are used in the main methods for the introduction of the peroxide group, such as the singlet-oxygen ene reaction with alkenes, the $[4+2]$-cycloaddition of singlet oxygen to dienes, the Mukaiyama-Isayama peroxysilylation of unsaturated compounds, the Kobayashi cyclization, the nucleophilic addition of hydrogen peroxide to carbonyl compounds, the ozonolysis, and reactions with the involvement of peroxycarbenium ions.

Each part of the review deals with a particular class of the above-mentioned peroxides in accordance with an increase in the number of oxygen atoms and the ring size. In the individual sections, the data are arranged mainly according to the common key step in the synthesis of the cyclic peroxides. Examples of the synthesis of peroxide derivatives via modifications of functional groups, with the peroxide bond remaining unbroken, are given in the end of each chapter. In most cases, the syntheses of compounds having high biological activity are considered.

Currently, the rapid progress in chemistry of organic peroxides is to a large degree determined by their high biological activity. In medicinal chemistry of peroxides, particular emphasis is given to the design of compounds having activity against causative agents of malaria and helminth infections. The World Health Organization (WHO) considers malaria as one of the most dangerous social diseases. Worldwide, 300-500 million cases of malaria occur each year, and 2 million people die from it $[47,48]$.

Due to a high degree of resistance in malaria to traditional drugs as quinine, chloroquine, and mefloquine, an active search for other classes of new drugs is performed. In this respect, organic peroxides play a considerable role. In medicinal chemistry of peroxides, artemisinin a natural peroxide exhibiting high antimalarial activity, is the most important drug in use for approximately 30 years. Artemisinin was isolated in 1971 from leaves of annual wormwood (Artemesia annua) [49-51]; the 1,2,4trioxane ring $\mathbf{V}$ is the key pharmacophore of these drugs. A series of semi-synthetic derivatives of artemisinin were synthesized: artesunate, artemether, and artemisone (Figure 2). Currently, drugs based on these compounds are considered as the most efficacious for the treatment of malaria [52-76].

The discovery of arterolane, a synthetic 1,2,4-trioxolane, is a considerable success in the search for easily available synthetic peroxides capable of replacing artemisinin and its derivatives in medical practice. Currently, this compound is currently in phase III clinical trials [77-81].

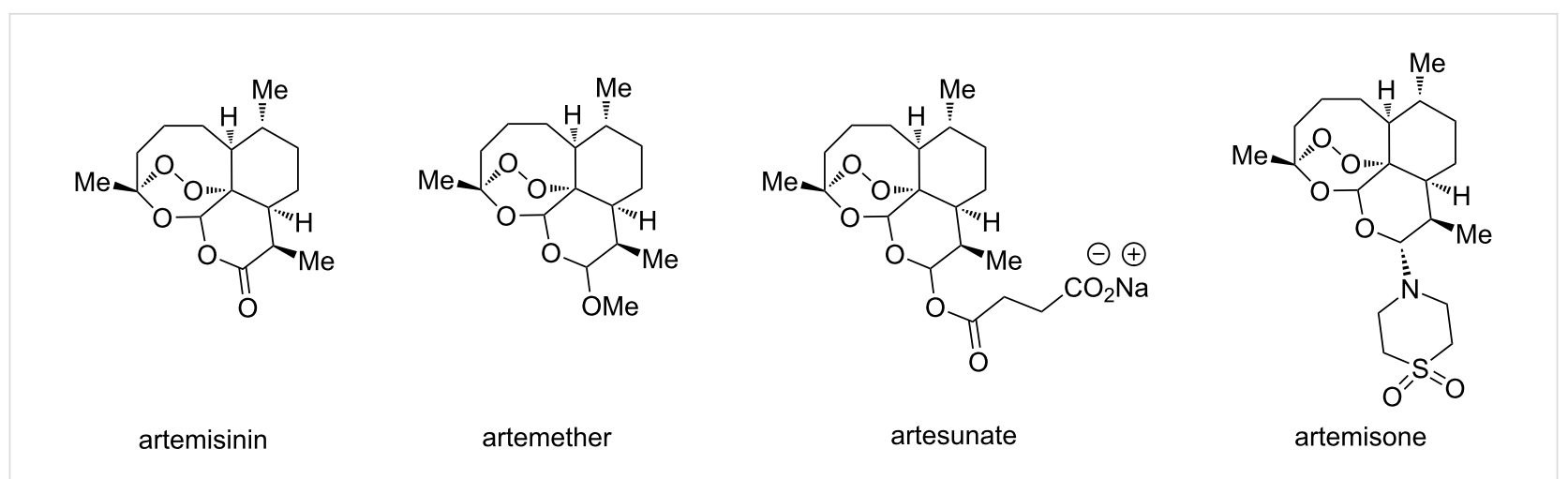

Figure 2: Artemisinin and semi-synthetic derivatives. 
The mechanism of antimalarial action of peroxides is unusual for pharmaceutical chemistry. According to the commonly accepted mechanism, peroxides diffuse into Plasmodiuminfected erythrocytes, and the heme iron ion of the latter reduces the peroxide bond to form a separated oxygen-centered radical anion, which rearranges to the $\mathrm{C}$-centered radical having a toxic effect on Plasmodium [82-87].

In the course of the large-scale search for synthetically accessible and cheap antimalarial peroxides (compared with natural and semi-synthetic structures), it was found that structures containing 1,2-dioxolane [88-90], 1,2,4-trioxolane [91-101], 1,2-dioxane [102-112], 1,2-dioxene [113-119], 1,2,4-trioxane [120-127] or 1,2,4,5-tetraoxane rings [128-146] exhibit pronounced activity, and in some cases, even superior to that of artemisinin.

Another important field of medicinal chemistry of organic peroxides includes the search for antihelminthic drugs. For example, compounds containing 1,2-dioxolane [147], 1,2,4trioxolane [148-152], 1,2,4-trioxane [153-158] or bridged 1,2,4,5-tetraoxane [159] moieties show activity against Schistosoma. Schistosomiasis is one of the most widespread helminthic diseases; 800 million people are at risk of acquiring this infection [160-174].

Additionally, based on synthetic peroxides, several compounds exhibiting antitumor activity were synthesized. These compounds contain 1,2-dioxolane [10-15,175-178], 1,2-dioxane [10-15,112,178-181], 1,2-dioxene [114,182-185] or 1,2,4trioxane $[10-15,175,176]$ rings. More than 300 peroxides are known to have a toxic effect on cancer cells [10-15,73,186206].

Synthetic peroxides exhibit also other activities. For example, compounds containing the 1,2,4-trioxane ring are active against Trichomonas [207], compounds with the 1,2-dioxane ring show antitrypanosomal and antileishmanial activities [208-212], and compounds containing the 1,2-dioxene ring possess fungicidal [210,213-224] and antimycobacterial activities [128-131,225228]. The present review covers literature relating to 5- and 6-membered cyclic peroxide chemistry published between 2000 and 2013.

\section{Review}

\section{Synthesis of 1,2-dioxolanes}

The modern approaches to the synthesis of 1,2-dioxolanes are based on the use of oxygen and ozone for the formation of the peroxide moiety, the Isayama-Mukaiyama peroxysilylation, and reactions involving peroxycarbenium ions. Syntheses employing hydrogen peroxide and the intramolecular Kobayashi cyclization are less frequently used.

\subsection{Use of oxygen for the peroxide ring formation}

The singlet-oxygen ene reaction with alkenes provides an efficient tool for introducing the hydroperoxide function. The reaction starts with the coordination of oxygen to the double bond followed by the formation of hydroperoxides presumably by a stepwise or concerted mechanism [229,230]. The oxidation of $\alpha, \beta$-unsaturated ketones $\mathbf{1} \mathbf{a}-\mathbf{c}$ by singlet oxygen affords 3-hydroxy-1,2-dioxolanes 3a-c via the formation of $\beta$-hydroperoxy ketones 2a-c (Scheme 1) [231].

Dioxolane 6 was synthesized in $36 \%$ yield by the reaction of oxygen with hydroperoxide 4 in the presence of di-tert-butyl peroxalate (DTBPO) followed by the treatment of the reaction mixture with acetic anhydride and pyridine at room temperature (Scheme 2).

It should be emphasized that a mixture of dioxolanes $\mathbf{5}$ and $\mathbf{6}$ in a ratio of 7:3 is formed already in the first step [232].

The photooxygenation of oxazolidines $7 \mathbf{a}-\mathbf{d}$ through the formation of hydroperoxides 8a-d gives spiro-fused oxazolidinecontaining dioxolanes 9a-d in low yields (12-30\%) (Scheme 3) [233].<smiles>[R]C([R])/C(C)=C1\CCOCCC1=O</smiles>

1a-c

a: $n=1 ; \mathrm{R}=\mathrm{R}^{\prime}=\mathrm{CH}_{3}$

b: $n=1 ; \mathrm{R}=\mathrm{H} ; \mathrm{R}^{\prime}=\mathrm{CH}_{3}$

c: $n=2 ; \mathrm{R}=\mathrm{R}^{\prime}=\mathrm{H}$

p-RB: polymer-based Rose Bengal<smiles>[R]C([R])C(C)(O)C1=CC[Te]CCC1=O</smiles>

2a-c<smiles>[R]C([R])[C@]1(C)OO[C@]2(O)CC[Te]CC=C12</smiles>

3a-c 


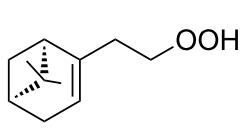

4

\section{1) $\mathrm{O}_{2}, \mathrm{DTBPO}$, benzene \\ 2) $\mathrm{Ac}_{2} \mathrm{O} /$ pyridine}

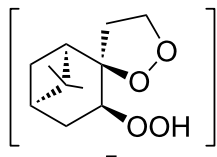

5

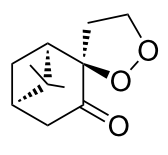

6

Scheme 2: Synthesis of dioxolane 6

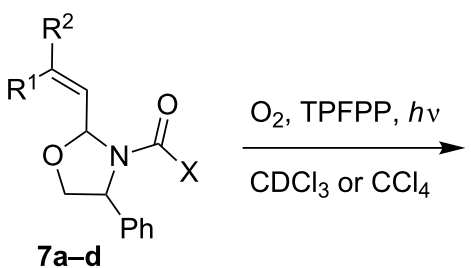

TPFPP $=5,10,15,20$-tetrakis (pentafluorophenyl)porphine

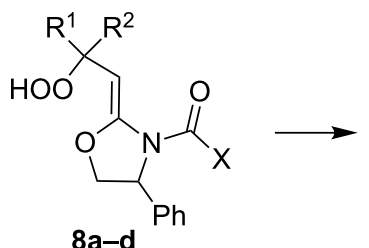

7-9 $R^{1} R^{2} X$<smiles>[X]C(=O)N1C([R])COC12CC([R])([R])OO2</smiles>

9a-d

Yield 9, \%

a MeMet-BuO- 25

b MeMePh 4

c MeMeNMePh 30

d EtMe NHPh 12

Scheme 3: Photooxygenation of oxazolidines $7 \mathbf{a}-\mathbf{d}$ with formation of spiro-fused oxazolidine-containing dioxolanes $9 \mathbf{a}-\mathbf{d}$.

The reaction was performed in a temperature range from -10 to $-5{ }^{\circ} \mathrm{C}$. The conversion of oxazolidines 7 and the yields of dioxolanes 9 were determined by ${ }^{1} \mathrm{H}$ NMR spectroscopy.

An efficient method for the synthesis of 1,2-dioxolanes is based on the oxidation of cyclopropanes by oxygen in the presence of transition-metal salts as the catalysts. The reactions of bicycloalkanols $\mathbf{1 0 a}-\mathbf{e}$ with singlet oxygen in the presence of catalytic amounts of $\mathrm{Fe}$ (III) acetylacetonate produce peroxides 12a-e, which can also be synthesized starting from silylated bicycloalkanols $\mathbf{1 1 a}-\mathbf{e}$ with the use of $\mathrm{Cu}(\mathrm{II})$ acetylacetonate (Scheme 4, Table 1) [234].

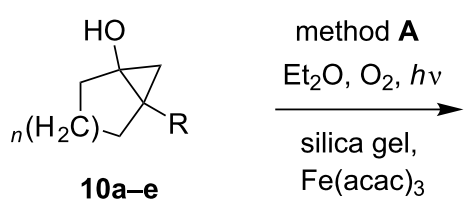<smiles>[R]C1([R])CCCCC1(O)OO</smiles>

$\frac{\text { method B }}{\text { 1) } \mathrm{EtOH}, \mathrm{ClSiMe}_{3}(2 \%)}$

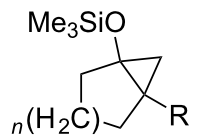

11a-e

Scheme 4: Oxidation of cyclopropanes $10 a-e$ and $11 a-e$ with preparation of 1,2-dioxolanes 12a-e.

Table 1: Structures and yields of dioxolanes 12a-e.

Bicycloalkanol 10a-e, silylated bicycloalkanol $11 \mathrm{a}-\mathrm{e}$

1,2-Dioxolane 12a-e

\begin{tabular}{|c|c|c|c|c|c|c|}
\hline & \multirow[b]{2}{*}{$\mathrm{R}$} & \multirow[b]{2}{*}{$n$} & \multicolumn{2}{|l|}{ Method $A^{a}$} & \multicolumn{2}{|l|}{ Method $B^{b}$} \\
\hline & & & Reaction time, $\mathrm{h}$ & Yield, \% & Reaction time, $\mathrm{h}$ & Yield, \% \\
\hline $\mathbf{a}$ & $\mathrm{CH}_{3}$ & 1 & 3 & 35 & 5 & 54 \\
\hline b & $\mathrm{C}_{4} \mathrm{H}_{9}$ & 1 & 3 & 55 & 3.5 & 84 \\
\hline c & $\mathrm{C}_{6} \mathrm{H}_{13}$ & 1 & 3 & 68 & - & - \\
\hline d & $\mathrm{CH}_{2} \mathrm{Ph}$ & 1 & 3 & 50 & 5 & 78 \\
\hline e & $\mathrm{CH}_{3}$ & 2 & 36 & 54 & 6 & 80 \\
\hline
\end{tabular}

${ }^{a} \mathrm{Et}_{2} \mathrm{O}, \mathrm{O}_{2}, h v$, silica gel, $\mathrm{Fe}(\mathrm{acac})_{3}(4 \mathrm{~mol} \%)$

${ }^{\mathrm{b}} \mathrm{EtOH}, \mathrm{O}_{2}, h v, \mathrm{Cu}(\mathrm{acac})_{2}(4 \mathrm{~mol} \%)$. 
Similarly, the reactions of silylated bicycloalkanols 13a-c with oxygen in the presence of the catalyst $\mathrm{VO}(\mathrm{acac})_{2}$ yielded dioxolanes 14a-c, which made it possible to perform the oxidation without irradiation (Scheme 5, Table 2) [235].<smiles>[R]C1CCCC2([R])CC12O[SiH3]</smiles>

$13 a-c$

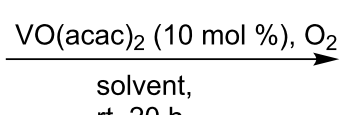

$\mathrm{rt}, 20 \mathrm{~h}$

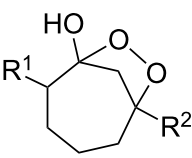

$14 a-c$
Scheme 5: $\mathrm{VO}(\mathrm{acac})_{2}$-catalyzed oxidation of silylated bicycloalkanols 13a-c.

Table 2: Structures and yields of dioxolanes 14a-c.

Silylated bicycloalkanol

13a-c

\begin{tabular}{|c|c|c|c|c|}
\hline & $\mathrm{R}^{1}$ & $\mathrm{R}^{2}$ & Solvent & $\begin{array}{l}\text { Yield } \\
14 a-c, \\
\%\end{array}$ \\
\hline \multirow{2}{*}{$\mathbf{a}$} & \multirow{2}{*}{$\mathrm{H}$} & \multirow{2}{*}{$\mathrm{Me}$} & $\mathrm{EtOH}$ & 45 \\
\hline & & & $\mathrm{CF}_{3} \mathrm{CH}_{2} \mathrm{OH}$ & 86 \\
\hline b & $\mathrm{H}$ & $\mathrm{Bn}$ & $\mathrm{CF}_{3} \mathrm{CH}_{2} \mathrm{OH}$ & 43 \\
\hline c & $\mathrm{Me}$ & $\mathrm{Me}$ & $\mathrm{CF}_{3} \mathrm{CH}_{2} \mathrm{OH}$ & 43 \\
\hline
\end{tabular}

This reaction gives $\beta$-hydroxyketones as by-products that are formed as a result of the decomposition of dioxolanes $\mathbf{1 4}$.

Cyclopropanols $\mathbf{1 5 a}-\mathbf{g}$ are readily oxidized by molecular oxygen in the presence of $\mathrm{Mn}(\mathrm{II})$ abietate or acetylacetonate (Scheme 6) [236].

Presumably, the reaction proceeds via the intermediate formation of $\mathrm{O}$ - and C-centered radicals $16 \mathbf{a}-\mathbf{g}$ and $\mathbf{1 7} \mathbf{a}-\mathbf{g}$, respectively. According to this method, dioxolanes $\mathbf{1 8 a}-\mathbf{g}$ (exist in equilibrium with the open form $19 \mathbf{a}-\mathbf{g}$ ) were synthesized in $60-80 \%$ yields.

Like hydroxycyclopropanes, aminocyclopropanes are transformed into 1,2-dioxolanes. For example, $\mathrm{N}$-cyclopropyl- $\mathrm{N}$ phenylamines 20a-c form dioxolanes $21 \mathbf{a}-\mathbf{c}$ in the presence of atmospheric oxygen (Table 3 ). It was found that the reaction rate substantially increases in the presence of catalytic amounts of $\left[(\text { phen })_{3} \mathrm{Fe}(\mathrm{III})\left(\mathrm{PF}_{6}\right)_{3}\right]$ or equimolar amounts of benzoyl peroxide or di-tert-butyl peroxide. The possible mechanism of the oxidation is shown in Scheme 7 [237].

According to the ${ }^{1} \mathrm{H}$ NMR data, dioxolanes 21a-c are formed under the above-mentioned conditions in almost quantitative yields; the yields based on the isolated product were not higher than $80 \%$ [237].

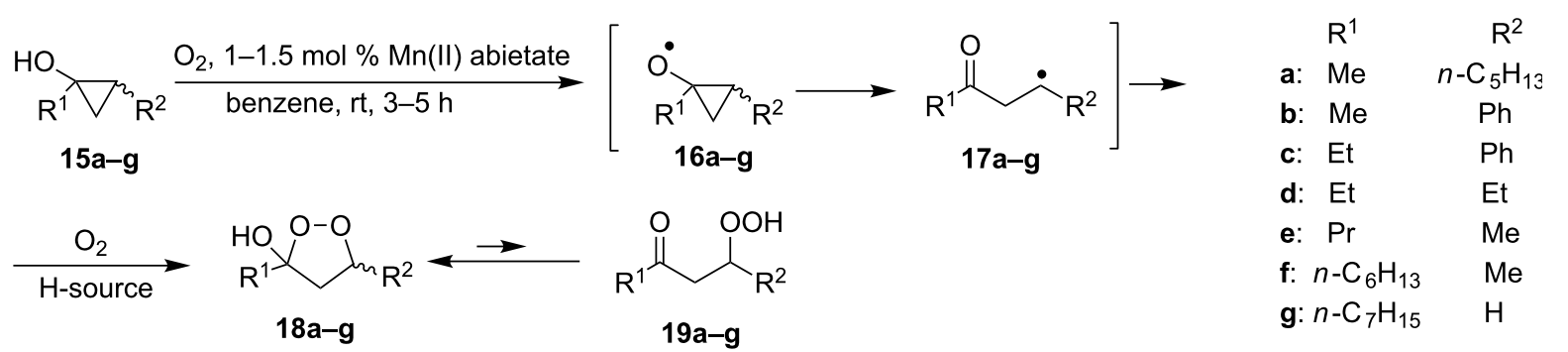

Scheme 6: Mn(II)-catalyzed oxidation of cyclopropanols $15 \mathbf{a}-\mathbf{g}$.

Table 3: Peroxidation of $N$-cyclopropyl- $N$-phenylamines $20 a-c$ to form 3-(1,2-dioxalanyl)- $N$-phenylamines 21a-c.

Dioxolane 21a-c

\begin{tabular}{|c|c|c|c|}
\hline & $\mathrm{R}^{1}$ & $\mathrm{R}^{2}$ & Reaction conditions \\
\hline $\mathbf{a}$ & $\mathrm{H}$ & $\mathrm{H}$ & $\begin{array}{l}\text { 1. }(\mathrm{BzO})_{2}(1 \mathrm{~mol} / 1 \mathrm{~mol} 2 \mathbf{2 0 a}), \mathrm{CHCl}_{3} \text {, dark, }-20{ }^{\circ} \mathrm{C}, 3 \text { days. } \\
\text { 2. }(t-\mathrm{BuO})_{2}(1 \mathrm{~mol} / 1 \mathrm{~mol} \mathrm{20a}), \mathrm{CHCl}_{3}, \mathrm{UV}(254 \mathrm{~nm}) \text {, ambient temperature, aerobic, } 2 \mathrm{~h} \text {. } \\
\text { 3. }\left[(\text { phen })_{3} \mathrm{Fe}(\mathrm{III})\left(\mathrm{PF}_{6}\right)_{3}\right](0.6 \% \mathrm{~mol}), \mathrm{CHCl}_{3}, \text { ambient temperature, aerobic, } 1 \mathrm{~h} \text {. }\end{array}$ \\
\hline b & Me & $\mathrm{H}$ & 1. $\left(t-\mathrm{BuO}_{2}(1 \mathrm{~mol} / 1 \mathrm{~mol} \mathbf{2 0 b}), \mathrm{CHCl}_{3}, \mathrm{UV}(254 \mathrm{~nm})\right.$, ambient temperature, aerobic, $2 \mathrm{~h}$. \\
\hline c & $\mathrm{H}$ & $\mathrm{Me}$ & $\begin{array}{l}\text { 1. }(t-\mathrm{BuO})_{2}(1 \mathrm{~mol} / 1 \mathrm{~mol} 20 \mathrm{c}), \mathrm{CHCl}_{3}, \mathrm{UV}(254 \mathrm{~nm}) \text {, ambient temperature, aerobic, } 2 \mathrm{~h} \text {. } \\
\text { 2. }\left[(\text { phen })_{3} \mathrm{Fe}(\mathrm{III})\left(\mathrm{PF}_{6}\right)_{3}\right](0.6 \% \mathrm{~mol}), \mathrm{CHCl}_{3}, \text { ambient temperature, aerobic, } 1 \mathrm{~h} \text {. }\end{array}$ \\
\hline
\end{tabular}




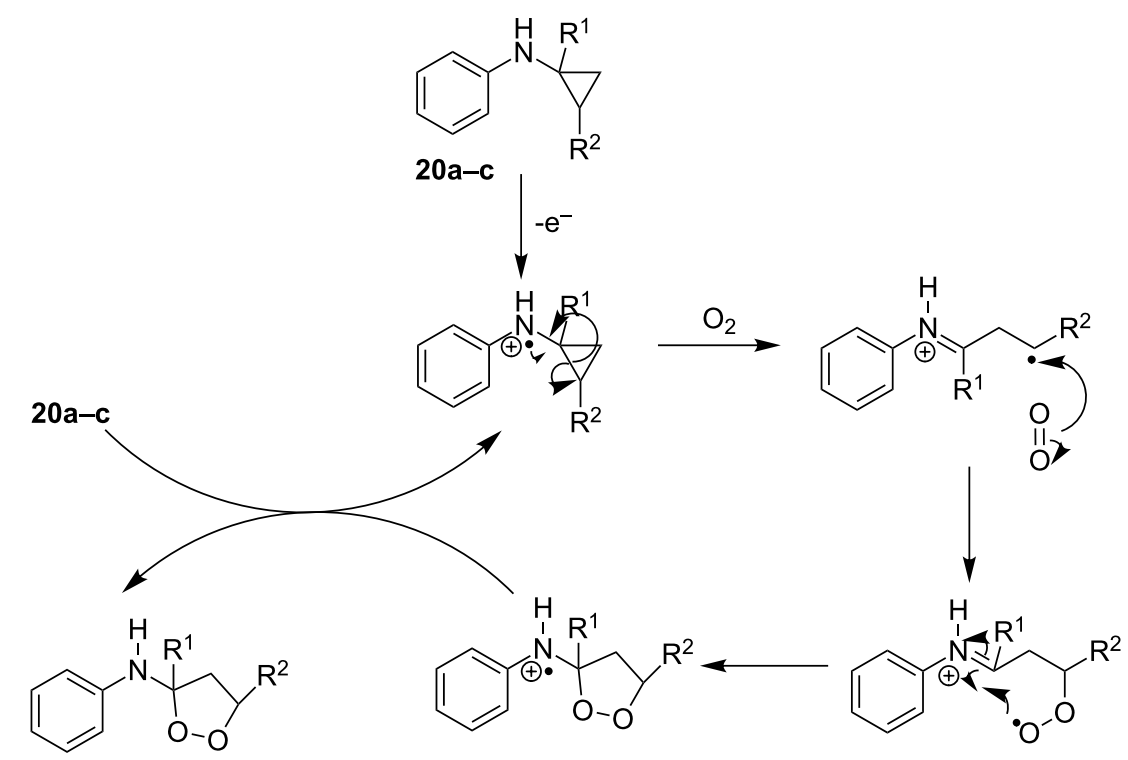

21a-c

Scheme 7: Oxidation of aminocyclopropanes 20a-c.

Structurally similar 3-ethyl-6a-methyl-6-(4-phenoxyphenyl)hexahydro[1,2]dioxolo[3,4-b]pyrroles 24a and 24b were synthesized from (Z)- $N$-(hex-3-enyl)- $N$-(4-phenoxyphenyl)acetamide (22). It was suggested that aminocyclopropane $\mathbf{2 3}$ is formed in situ, which is subsequently oxidized in air on silica gel (Scheme 8) [238]. The total yield of both isomers $\mathbf{2 4}$ was $31 \%$.

Trifluoromethyl-containing dioxolane $\mathbf{2 5}$ (Figure 3) was synthesized according to this method in $40 \%$ yield [239].

A series of 1,2-dioxolanes $\mathbf{2 7 a - e}$ containing various functional groups $\mathrm{R}$ were prepared by the oxidation of cyclopropanes 26a-e (Scheme 9, Table 4).

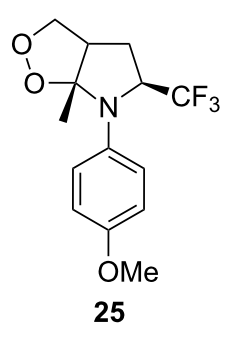

Figure 3: Trifluoromethyl-containing dioxolane 25.

The reaction was performed in the presence of $\mathrm{Ph}_{2} \mathrm{Se}_{2}$ (10 mol \%) and azobisisobutyronitrile (AIBN, $8 \mathrm{~mol} \%$ ) in air under irradiation for two days. The product was purified by<smiles>CC/C=C\CCN(C(C)=O)c1ccc(Oc2ccccc2)cc1</smiles>

22
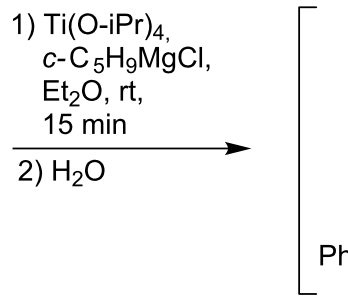
$\mathrm{PhO}$

23<smiles>CCC1OOC2(C)C1CCN2c1ccc(Oc2ccccc2)cc1</smiles>

$56: 44$

24a

$24 b$ 


Scheme 9: Synthesis of 1,2-dioxolanes 27a-e by the oxidation of cycloproper

flash chromatography to obtain a mixture of cis and trans isomers, whose ratio depends primarily on the nature of the substituent in cyclopropanes 26a-e [240].

The oxidation of methylenecyclopropanes $\mathbf{2 8 a}$ and $\mathbf{2 8 b}$ under photoinduced electron-transfer conditions is described by a similar scheme (Scheme 10).

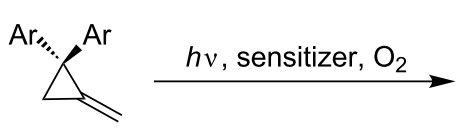

28a

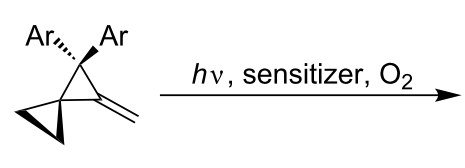

$28 b$

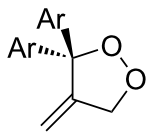

$29 a$
Scheme 10: Photoinduced oxidation of methylenecyclopropanes 28
The reaction was performed in acetonitrile or in a mixture of toluene and acetonitrile with the use of 9,10-dicyanoanthracene (DCA), 1,2,4,5-tetracyanobenzene (TCNB), or $N$-methyl-quinolinium tetrafluoroborate $\left(\mathrm{NMQ}^{+} \mathrm{BF}_{4}^{-}\right)$as sensitizers. Under these conditions, dioxolane 29a was obtained in quantitative yield $\left({ }^{1} \mathrm{H}\right.$ NMR data), the yield of $\mathbf{2 9 b}$ was not reported [241].

Under irradiation in the presence of oxygen, 1,5-bis(4methoxyphenyl)bicyclo[3.1.0]hexane (30) and 1,5-bis(4methoxyphenyl)-6,7-diazabicyclo[3.2.1] oct-6-ene (31) were transformed into bicyclic dioxolane 33. It was suggested that both reactions proceed via the formation of 1,3-radical cation 32 (Scheme 11).

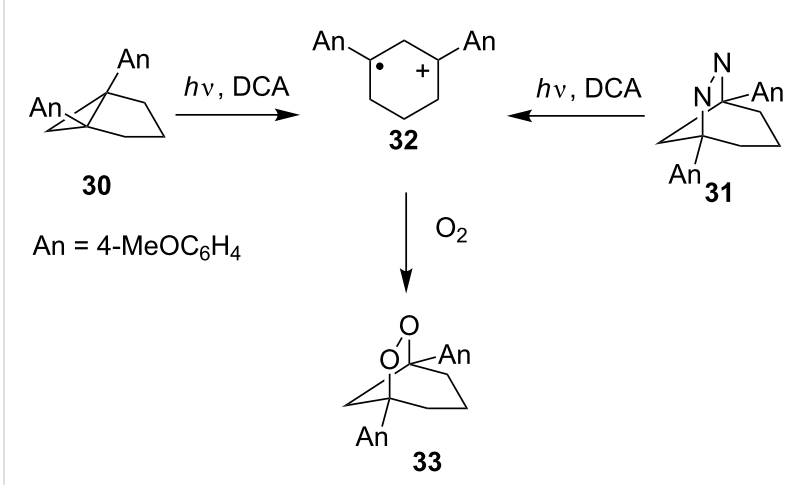

Scheme 11: Irradiation-mediated oxidation.

Dioxolane 33 was synthesized in the highest yields (91\% from 30 and 100\% from 31) in acetonitrile with the use of 9,10dicyanoanthracene (DCA) as the sensitizer [242].

After irradiation of diazene 34 in an argon matrix at $10 \mathrm{~K}$, biradical 35 was detected by IR spectroscopy and the reaction of the latter with oxygen at $10 \mathrm{~K}$ proceeded regioselectively to give dioxolane 36 (Scheme 12) [243].

Bicyclic peroxide 2-heptyl-3,4-dioxabicyclo[3.3.0]oct-1(8)-ene was prepared by a similar process [244].

The oxidation of arylacetylenes $37 \mathbf{a}-\mathbf{h}$ with atmospheric oxygen in the presence of catalytic amounts of $\mathrm{Mn}(\mathrm{OAc})_{3}$ in an 


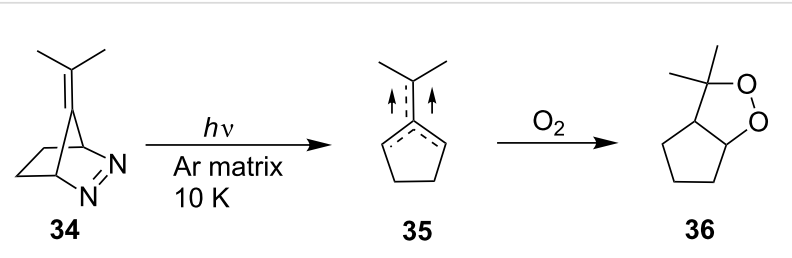

Scheme 12: Application of diazene 34 for dioxolane synthesis.

excess of acetylacetone afforded dioxolanes $\mathbf{3 8 a}-\mathbf{h}$ in moderate yields (34-64\%) (Scheme 13, Table 5) [245].<smiles>[R17]C(=O)CC(C)=O</smiles>

Scheme 13: $\mathrm{Mn}(\mathrm{OAc})_{3}$-catalyzed cooxidation of arylacetylenes $37 \mathrm{a}-\mathbf{h}$ and acetylacetone with atmospheric oxygen.

\begin{tabular}{|c|c|c|c|}
\hline $37 a-h$ & $\mathrm{R}^{1}$ & $\begin{array}{l}\text { Yield 38a-h, } \\
\%\end{array}$ & $\begin{array}{l}\text { Yield 39a-h, } \\
\%\end{array}$ \\
\hline $\mathbf{a}$ & $\mathrm{Ph}$ & 45 & 5 \\
\hline b & $4-\mathrm{MeC}_{6} \mathrm{H}_{4}$ & 52 & 7 \\
\hline c & $4-\mathrm{MeOC}_{6} \mathrm{H}_{4}$ & 64 & 2 \\
\hline d & $4-\mathrm{ClC}_{6} \mathrm{H}_{4}$ & 38 & 2 \\
\hline e & $4-\mathrm{FC}_{6} \mathrm{H}_{4}$ & 41 & 6 \\
\hline $\mathbf{F}$ & 1-naphthyl & 54 & 6 \\
\hline g & 2-naphthyl & 52 & 8 \\
\hline h & $3,4-(\mathrm{MeO})_{2} \mathrm{C}_{6} \mathrm{H}_{3}$ & 34 & 11 \\
\hline
\end{tabular}

The reaction was performed at $23{ }^{\circ} \mathrm{C}$ in glacial acetic acid in air; the $37 /$ acetylacetone $/ \mathrm{Mn}(\mathrm{OAc})_{3}$ molar ratio was $1 / 10 / 10$. The reaction gave oxiranes 39 as by-products, which can also be synthesized in quantitative yields by the treatment of dioxolanes 38 with silica gel in methanol [245].

\subsection{Peroxidation of alkenes with the $\mathrm{Co}(\mathrm{II}) / \mathrm{Et}_{3} \mathrm{SiH} /$ $\mathrm{O}_{2}$ system (Isayama-Mukaiyama reaction)}

Peroxysilylation of alkenes with molecular oxygen in the presence of triethylsilane catalyzed by cobalt(II) diketonates was described for the first time by S. Isayama and T. Mukaiyama in 1989 [246,247]. Currently, this approach is one of the main methods for the preparation of peroxides from alkenes.

Compounds (oxidized by the Isayama-Mukaiyama reaction) containing a reaction center that can be subjected to the attack by a peroxide radical, are able to undergo intramolecular cyclization to form the 1,2-dioxolane ring. For example, the $\operatorname{Co}(\operatorname{modp})_{2}$-catalyzed peroxysilylation $(\operatorname{modp}=$ 1-morpholino-5,5-dimethyl-1,2,4-hexanetrionate) of (2-vinylcyclopropyl)benzene (40) affords triethyl(1-(5-phenyl-1,2-dioxolan-3-yl)ethylperoxy)silane (41) in 37\% yield (Scheme 14).

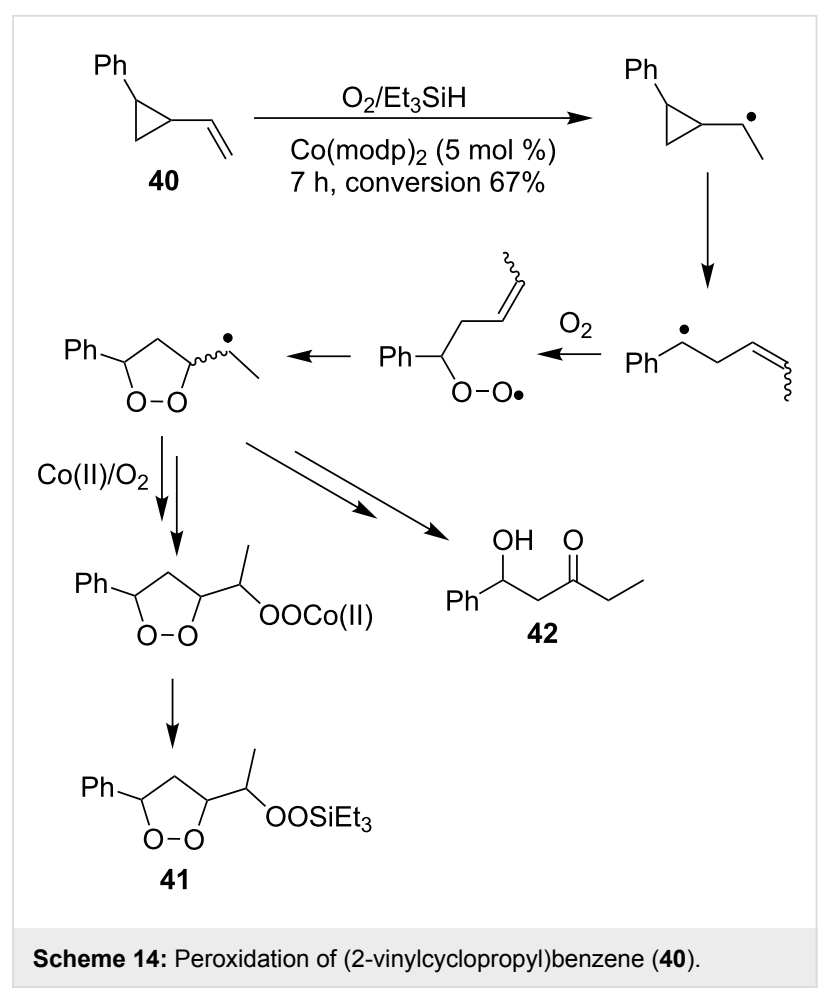

The reaction was carried out in 1,2-dichloroethane at room temperature, and the reaction products were separated by column chromatography. 1-Hydroxy-1-phenylpentan-3-one (42) was isolated as a by-product in $16 \%$ yield [248].

The peroxidation of 1,4-dienes $43 \mathbf{a}, \mathbf{b}$ with the $\operatorname{Co}(\operatorname{modp})_{2} /$ $\mathrm{Et}_{3} \mathrm{SiH} / \mathrm{O}_{2}$ system according to a similar reaction scheme gave dioxolanes 44a,b. Acetophenone (45) was obtained as the by-product (Scheme 15, Table 6) [249].

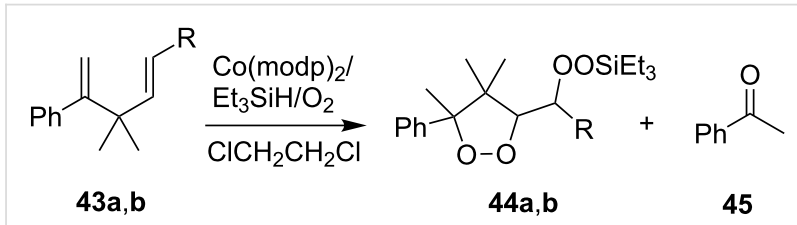

Scheme 15: Peroxidation of 1,4-dienes 43a,b

The desilylation of the initially formed silicon peroxide followed by cyclization of the hydroperoxide accompanied by the attack on the electrophilic center is another example of the use 


\begin{tabular}{|cccccc|}
\hline $\begin{array}{c}\text { Table 6: Synthesis of dioxolanes } \\
\text { 1,4-Diene, } \mathbf{b .} \\
\mathbf{4 3}\end{array}$ & $\mathrm{R}$ & $\begin{array}{c}\text { Reaction } \\
\text { time, } \\
\mathrm{h}\end{array}$ & $\begin{array}{c}\text { Conversion, } \\
\%\end{array}$ & Yield, $\%$ \\
\hline & & & & 44 & 45 \\
\hline a & H & 4.5 & 47 & 27 & 49 \\
b & COOEt & 2 & 44 & 56 & 22 \\
\hline
\end{tabular}

of the Isayama-Mukaiyama reaction for the synthesis of cyclic peroxides. In some cases, the reaction with 1,5-dienes 46a-d produces, along with 1,2-dioxanes 51 (desilylation products of the corresponding 1,2-dioxanes 48), 1,2-dioxolanes (52b,d) as a result of cyclization of the corresponding peroxysilyl epoxides 49. In these reactions, unsaturated triethylsilyl peroxides 47 are formed as by-products, which are desilylated during hydrolysis to give the unsaturated hydroperoxides $\mathbf{5 0}$ (Scheme 16, Table 7) [249].

1,2-Dioxolanes can be produced from oxetanes $\mathbf{5 3 a}, \mathbf{b}$ containing a double bond in the side chain according to a similar scheme. The first step afforded peroxysilanes $\mathbf{5 4 a}, \mathbf{b}$, which upon treatment with aqueous HF gave the target dioxolanes 55a,b (Scheme 17) [250].

A similar way to 1,2-dioxolanes used an oxirane cycle for the stages of ring opening followed by 1,2-dioxolane ring closing [251].

The synthesis of spirodioxolane $\mathbf{5 9}$ involved the peroxysilylation of 1,3-dicyclohexenylpropan-2-yl acetate (56) catalyzed by cobalt complexed with 2,2,6,6-tetramethylheptane-3,5-dione $\left(\mathrm{Co}(\mathrm{THD})_{2}\right)$ as the first step giving 1,3-bis(1-(triethylsilylperoxy)cyclohexyl)propan-2-yl acetate $(\mathbf{5 7})$ that was subse-

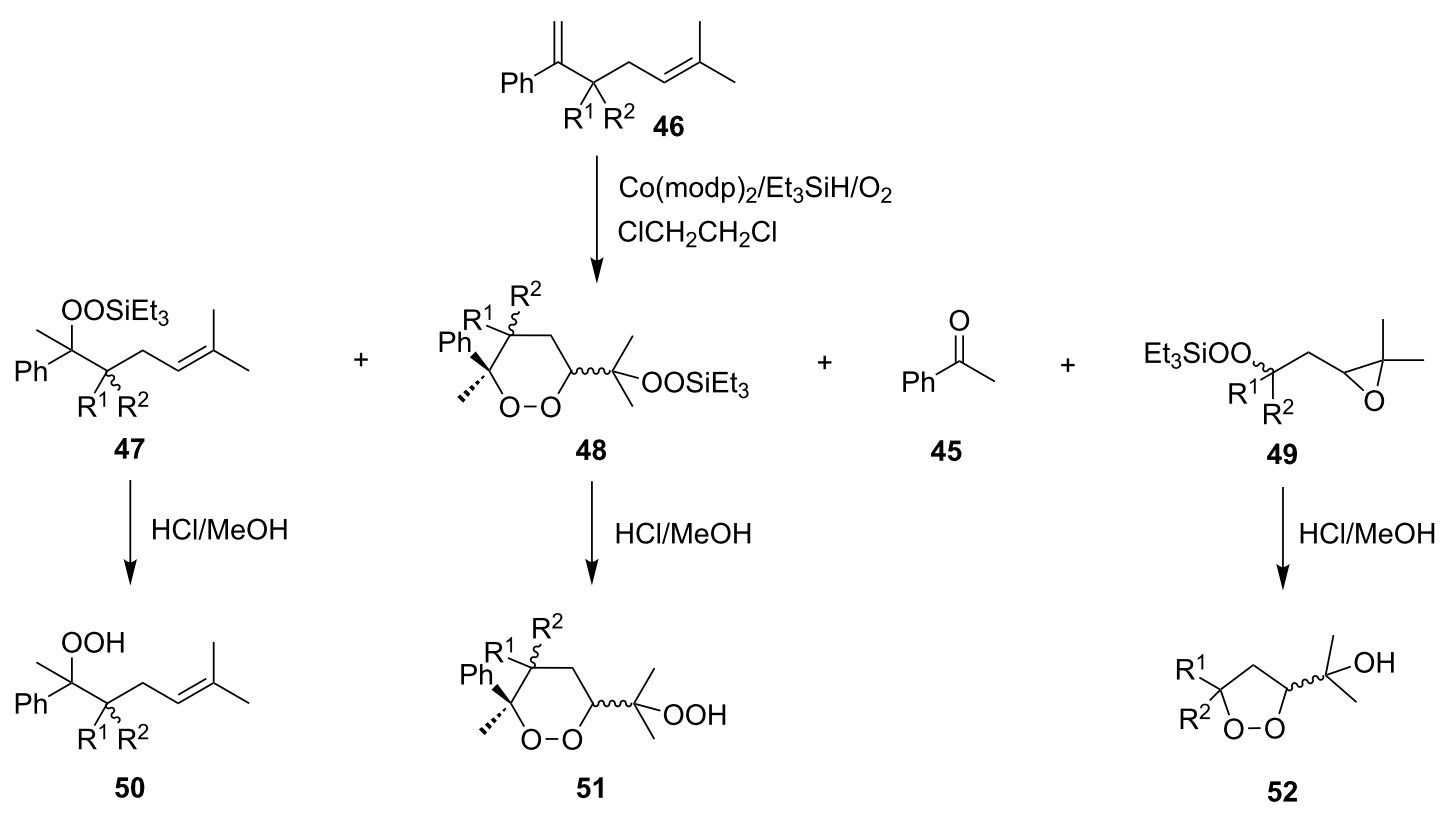

Scheme 16: Peroxidation of 1,5-dienes 46.

Table 7: Peroxidation of 1,5-dienes 46

\begin{tabular}{|c|c|c|c|c|c|c|c|c|c|}
\hline \multirow{2}{*}{ Diene 46} & \multirow{2}{*}{$\mathrm{R}^{1}$} & \multirow{2}{*}{$\mathrm{R}^{2}$} & \multirow{2}{*}{ Reaction time, $\mathrm{h}$} & \multirow{2}{*}{ Conversion, \% } & \multicolumn{5}{|c|}{ Yield $^{a}, \%$} \\
\hline & & & & & 45 & 49 & 50 & 51 & 52 \\
\hline $\mathbf{a}$ & $\mathrm{H}$ & $\mathrm{H}$ & 6 & 82 & 4 & - & 13 & 31 & - \\
\hline b & $\mathrm{H}$ & $\mathrm{Me}$ & 2.5 & 83 & 36 & - & 12 & 13 & 33 \\
\hline C & $\mathrm{H}$ & $\mathrm{Ph}$ & 3.5 & 75 & 57 & 38 & 7 & 27 & - \\
\hline d & $\mathrm{Me}$ & $\mathrm{Me}$ & 3 & 84 & 51 & - & - & 31 & 26 \\
\hline
\end{tabular}

aThe yields are given based on the converted dienes $46 a-d$. 


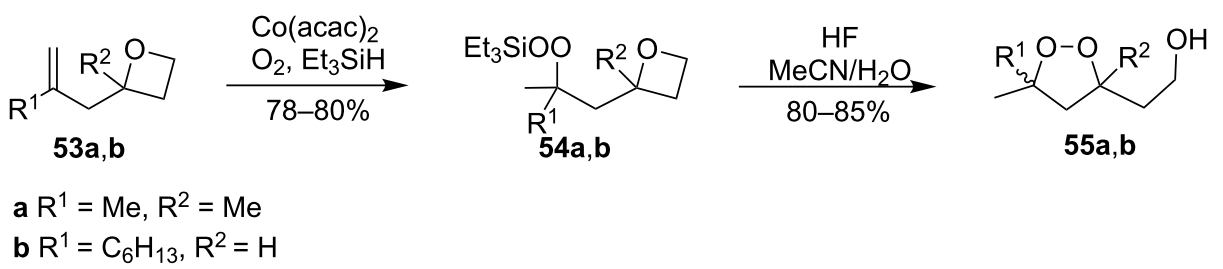

Scheme 17: Peroxidation of oxetanes 53a,b.

quently transformed into the carbonyl-containing diperoxide (1,3-bis(1-(triethylsilylperoxy)cyclohexyl)propan-2-one) (58) in two steps. The latter was treated with $p-\mathrm{TsOH}$ to give the target peroxide 59 (Scheme 18) [252].

\subsection{The use of ozone. Peroxycarbenium ions in the} 1,2-dioxolanes synthesis

The ozonolysis of unsaturated compounds is a reliable and facile method for the introduction of the peroxide functional group. As in the above-considered studies, the intramolecular cyclization of ozonolysis products can be performed with the use of the hydroperoxide group provided that there is an appropriate electrophilic center.

The reaction of oxetanes $\mathbf{6 0 a}, \mathbf{b}$ with ozone in methanol produced 3-alkoxy-1,2-dioxolanes 62a,b. The analysis of the reaction mixture (TLC, NMR) confirmed that cyclic peroxides are formed immediately in the reaction mixture rather than in the course of the treatment or purification of the reaction products. It was suggested that the reaction proceeds via the formation of hydroperoxy acetals 61a,b (Scheme 19) [250].

The ozonolysis of 9-methyleneheptadecane-7,11-diylbis(methanesulfonate) (63) gave 9-oxoheptadecane-7,11-diylbis(methanesulfonate) (64). The latter reacted with $\mathrm{H}_{2} \mathrm{O}_{2}$ in the presence of sulfuric acid (or iodine) as the catalyst to form 9,9dihydroperoxyheptadecane-7,11-diyl-bis(methanesulfonate) $\mathbf{6 5}$, and the replacement of the mesyl groups in the latter compound afforded 3,8-dihexyl-1,2,6,7-tetraoxaspiro[4.4]nonane (66, Scheme 20). The yield of dioxolane $\mathbf{6 6}$ was $36 \%$ based on $\mathbf{6 3}$ [252].

The treatment of 3,3'-(cyclohexa-3,6-diene-1,3-diyl)dipropan-1ol (67) and 4,4'-(cyclohexa-3,6-diene-1,3-diyl)dibutan-2-ol (69)<smiles>CC(=O)OC(CC1=CCCCC1)CC1=CCCCC1</smiles>

56<smiles>C1CCC2(CC1)CC1(CC3(CCCCC3)OO1)OO2</smiles>

59
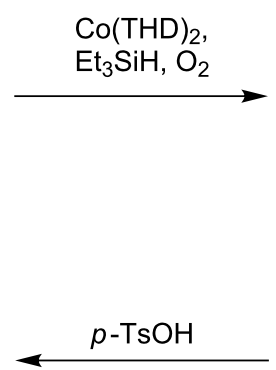

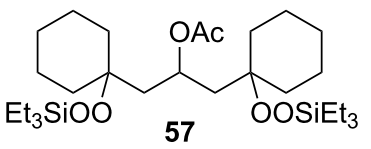

1. $\mathrm{iBu}_{2} \mathrm{AlH}$

2. Dess-Martin periodinane

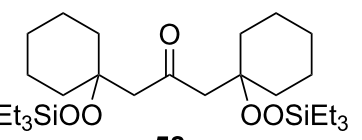

58

Scheme 18: Peroxidation of 1,6-diene 56.

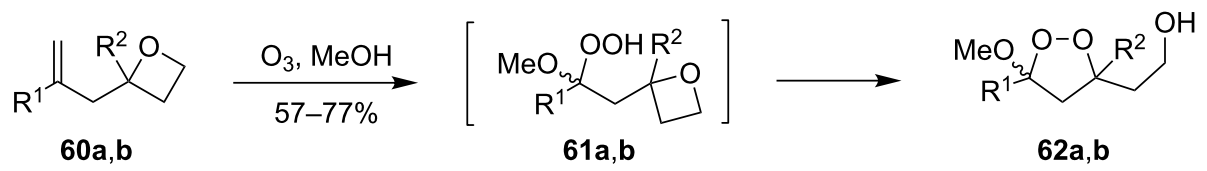

a $\mathrm{R}^{1}=\mathrm{Me}, \mathrm{R}^{2}=\mathrm{Me}$

b $\mathrm{R}^{1}=\mathrm{C}_{6} \mathrm{H}_{13}, \mathrm{R}^{2}=\mathrm{H}$ 


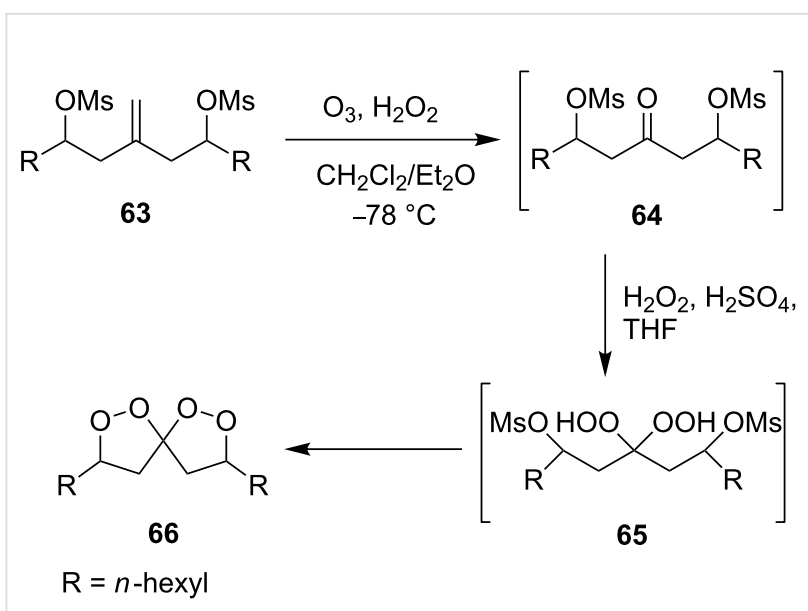

Scheme 20: Synthesis of spiro-bis(1,2-dioxolane) 66 .

with ozone in $\mathrm{MeOH} / \mathrm{CH}_{2} \mathrm{Cl}_{2}$ followed by the addition of a catalytic amount of $p$-TsOH lead to the intramolecular peroxyketalization that proceeds through the formation of the peroxycarbenium ion (shown in Scheme 21 for the ozonolysis of $\mathbf{6 7}$ as an example) to give finally dispiro-1,2-dioxolanes: $1,8,12,13$ tetra-oxadispiro-[4.1.4.2] tridecane $\mathbf{6 8}$ (yield 67\%) and two isomers of 2,9-dimethyl-1,8,12,13-tetraoxadispiro[4.1.4.2]tridecane 70 and 71 (combined yield 72\%) (Scheme 21) [253].

The spirohydroperoxydioxolanes, 5-hydroperoxy-2',3'-dihydrospiro[[1,2]dioxolane-3,1'-indene] (75a) and 5-hydroperoxy3',4'-dihydro-2' $H$-spiro[[1,2]dioxolane-3,1'-naphthalene] (75b), were synthesized by the ozonolysis of 1-allyl-1-hydroperoxy2,3-dihydro- $1 H$-indene (72a) and 1-allyl-1-hydroperoxy1,2,3,4-tetrahydronaphthalene (72b), respectively, in an $\mathrm{Et}_{2} \mathrm{O} /$ $\mathrm{CF}_{3} \mathrm{CH}_{2} \mathrm{OH}$ system $(2: 1)$. The reaction proceeds via the formation of ozonide $\mathbf{7 3}$ followed by elimination of formaldehyde to give peroxycarbenium ion $\mathbf{7 4}$ that undergoes cyclization via the attack of the hydroperoxide group on the carbon center of peroxycarbenium ion 74 (Scheme 22) [254].

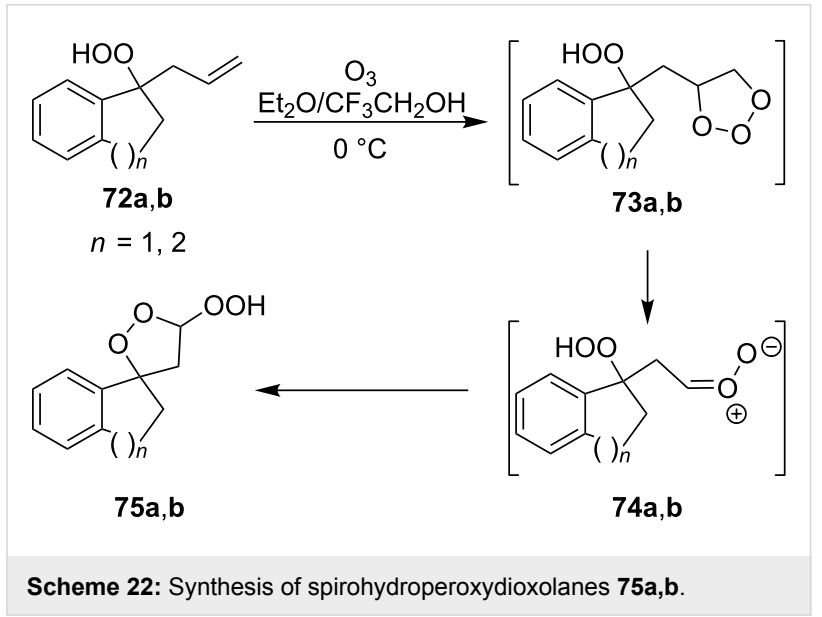

Spirohydroperoxydioxolane 75a $(n=1)$ was obtained in $71 \%$ yield (the diastereoisomeric ratio was $1: 1)$; the yield of $\mathbf{7 5 b}(n=$ 2) was $21 \%$ (the diastereoisomeric ratio was $1: 1$ ).

5'-Hydroperoxyspiro[chromane-2,3'-[1,2]dioxolane] (77, yield $18 \%$ ) and (3S,5S)-3,5-dihydroperoxy-3-(3-phenylpropyl)-1,2dioxolane (79, yield 22\%) (Scheme 23) were synthesized in a similar way starting from 2-allyl-2-hydroperoxychromane (76) and (4,4-dihydroperoxyhept-6-enyl)benzene (78), respectively [254].

An oxidative rearrangement takes place in the reaction of azepino[4,5- $b$ ] indole $\mathbf{8 0}$ with ozone. The addition of ozone to the endocyclic double bond (molozonide 81) and the formation of the Criegee intermediate are followed by a 1,3-dipolar interaction of the peroxycarbenium ion with the double bond (82) to form dioxolane 83 . The yield was not lower than $48 \%$ but no exact yield was reported (Scheme 24) [255].

The peroxycarbenium ions produced by the decomposition of 1,2,4-trioxolanes can be trapped with allyltrimethylsilane. For example, the $\mathrm{SnCl}_{4}$-mediated fragmentation of ozonides 84a-I

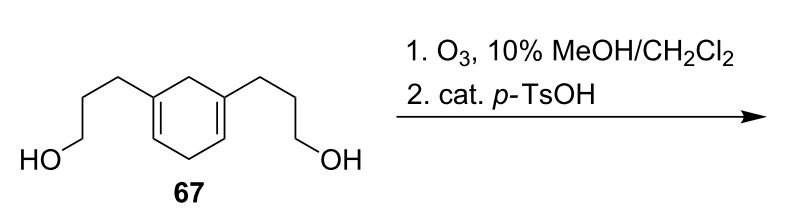<smiles>CC(O)CCC1=CCC=C(CCC(C)O)C1</smiles>

69

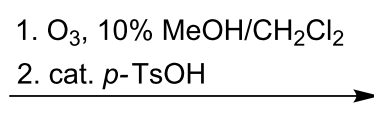

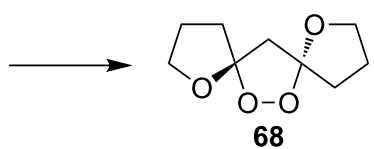

$\mathrm{X}=\mathrm{OH}$ or $\mathrm{OOH}$ or $\mathrm{OMe}$

70

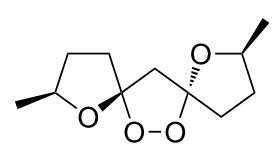<smiles>C[C@H]1CC[C@]2(C[C@@]3(CC[C@@H](C)O3)OO2)O1</smiles>

71

Scheme 21: Synthesis of dispiro-1,2-dioxolanes 68, 70, 71. 


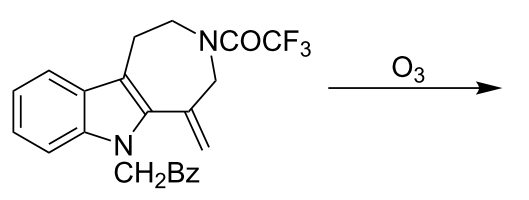

80

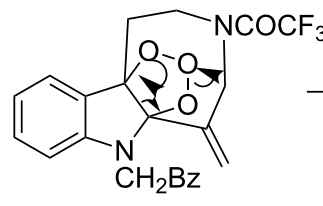

81

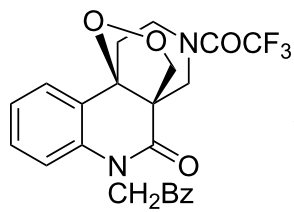

83

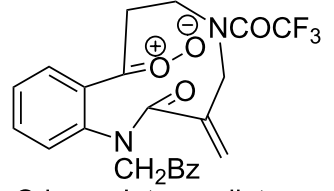

Criegee Intermediate

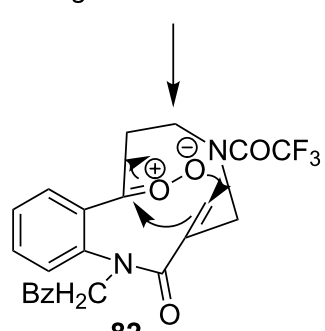

Scheme 24: Ozonolysis of azepino[4,5-b]indole $\mathbf{8 0 .}$<smiles>C=CCC1(O)CCc2ccccc2O1</smiles>

76<smiles>C=CCC(O)(O)CCCc1ccccc1</smiles>

78

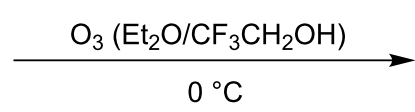

$\frac{\mathrm{O}_{3}\left(\mathrm{Et}_{2} \mathrm{O} / \mathrm{CF}_{3} \mathrm{CH}_{2} \mathrm{OH}\right)}{0^{\circ} \mathrm{C}}$<smiles>OC1CC2(CCc3ccccc3O2)OO1</smiles>

77

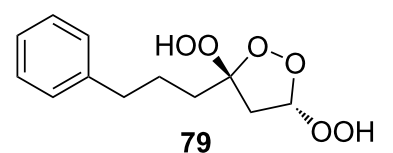

Scheme 23: Synthesis of spirohydroperoxydioxolane 77 and dihydroperoxydioxolane 79 .

in the presence of allyltrimethylsilane in dichloromethane gives a complex mixture of products $\mathbf{8 5}-\mathbf{9 4}$, including dioxolanes 86a-i, 87i, 90j-l, and 91j (Scheme 25, Table 8) [256].

Treatment of the bicyclic ozonide 1-methyl-6,7,8trioxabicyclo[3.2.1] octane $\mathbf{8 4 m}$, with $\mathrm{SnCl}_{4}$ in the presence of allyltrimethylsilane produces a mixture of two cis diastereomers and two trans diastereomers (in a ratio of 35:35:15:15) of 7-(3-methyl-5-((trimethylsilyl)methyl)-1,2-dioxolan-3-yl)hept1 -en-4-ol 95 in a total yield of $48 \%$ (Scheme 26) [256].

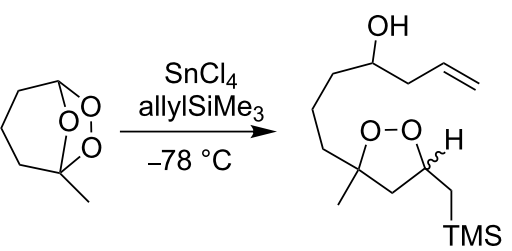

$84 m$

Scheme 26: $\mathrm{SnCl}_{4}$-mediated fragmentation of bicyclic ozonide $\mathbf{8 4 m}$ in the presence of allyltrimethylsilane.

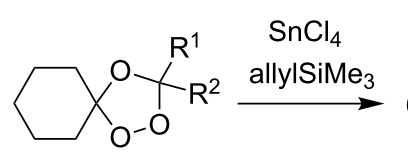

$84 a-i$<smiles>O=C1CCCCO1</smiles>

85<smiles>CC(C)CC1CC2(CCCCC2)OO1</smiles>

86<smiles>[R]C(=O)[R17]C=CCC([R1])([R])O</smiles>

87

88

89

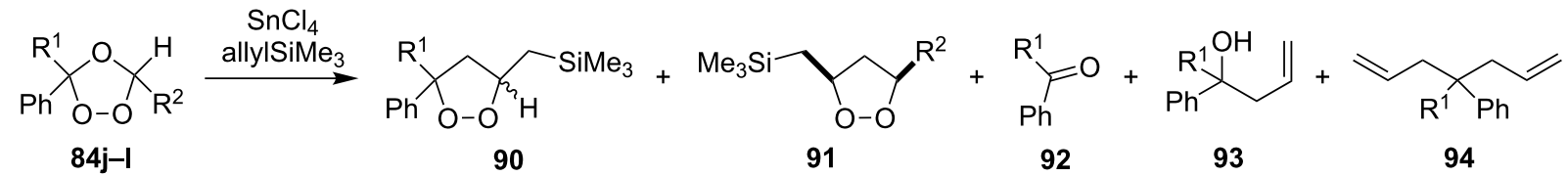


Table 8: The $\mathrm{SnCl}_{4}$-mediated fragmentation of ozonides $84 \mathrm{a}-\mathrm{I}$ in the presence of allyltrimethylsilane.

Yield, \%

\begin{tabular}{|c|c|c|c|c|c|c|c|c|}
\hline Ozonide 84 & $\mathrm{R}^{1}$ & $\mathrm{R}^{2}$ & $T,{ }^{\circ} \mathrm{C}$ & Lactone 85 & Dioxolane 86 & Dioxolane 87 & Ketone 88 & Alcohol 89 \\
\hline $\mathbf{a}$ & \multicolumn{2}{|c|}{$-\left(\mathrm{CH}_{2}\right)_{4}-$} & -78 to 0 & 11 & 50 & - & 88a (traces) & - \\
\hline b & \multicolumn{2}{|c|}{$-\left(\mathrm{CH}_{2}\right)_{5^{-}}$} & -78 to 0 & 17 & 57 & - & $\mathbf{8 8 b}$ (traces) & - \\
\hline c & \multicolumn{2}{|c|}{$-\left(\mathrm{CH}_{2}\right)_{6-}^{-}$} & -78 to 0 & 39 & 24 & - & 88c (traces) & - \\
\hline d & $\mathrm{CH}_{3}$ & $\mathrm{Ph}$ & -78 to 0 & 25 & 61 & - & 88d (93\%) & - \\
\hline e & $\mathrm{C}_{4} \mathrm{H}_{9}$ & $\mathrm{C}_{4} \mathrm{H}_{9}$ & -78 to 0 & 40 & 14 & - & $88 \mathrm{e}(70 \%)$ & 75 \\
\hline$f$ & $\mathrm{H}$ & $\mathrm{C}_{8} \mathrm{H}_{17}$ & -78 & - & 56 & - & - & 50 \\
\hline g & $\mathrm{H}$ & $\mathrm{Ph}$ & -78 & - & 79 & - & - & 13 \\
\hline h & $\mathrm{H}$ & $\mathrm{H}$ & -78 & - & 10 & - & - & - \\
\hline i & $\mathrm{CH}_{3}$ & $\mathrm{C}\left(\mathrm{CH}_{3}\right)_{3}$ & -78 to 0 & 31 & 21 & 9 (cis) & - & - \\
\hline Ozonide 84 & $\mathrm{R}^{1}$ & $\mathrm{R}^{2}$ & $T,{ }^{\circ} \mathrm{C}$ & $\begin{array}{l}\text { Dioxolane } 90 \\
\text { (cis:trans) }\end{array}$ & Dioxolane 91 & $\begin{array}{l}\text { Carbonyl } \\
\text { compound } 92\end{array}$ & Alcohol 93 & Alkene 94 \\
\hline j & $\mathrm{H}$ & $\mathrm{C}_{3} \mathrm{H}_{7}$ & -78 & $15(1: 1)$ & 7 & 39 & 93j (20\%) & - \\
\hline k & $\mathrm{H}$ & $\mathrm{H}$ & -78 & $15(1: 1)$ & - & 22 & 93j (24\%) & - \\
\hline I & $\mathrm{CH}_{3}$ & $\mathrm{H}$ & -78 & $9(1: 1)$ & - & 43 & - & 2.5 \\
\hline
\end{tabular}

These syntheses of dioxolanes involve the formation of the peroxycarbenium ion as the key step. The reaction of the latter with allyltrimethylsilane followed by the intramolecular cyclization finally leads to the dioxolane ring.

Dioxolanes 99-102 are produced from alkoxyhydroperoxides 96a-g (ozonolysis products of alkenes) in a similar way. The first step results in the formation of peroxycarbenium ions $\mathbf{9 7}$, which are trapped with allyltrimethylsilane under the formation of intermediate hydroperoxides 98. Then either cyclic dioxolanes 99-102 or unsaturated compounds 103-107 are formed as the major reaction products depending on the nature of the substituents and the Lewis acid (Scheme 27, Table 9) [257].

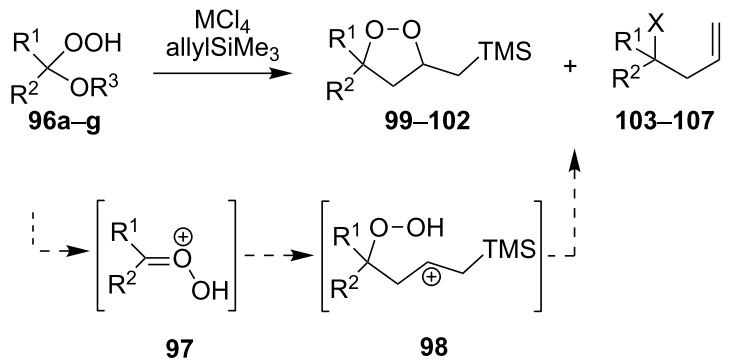

Scheme 27: $\mathrm{MCl}_{4}$-mediated fragmentation of alkoxyhydroperoxides 96 in the presence of allyltrimethylsilane.

\begin{tabular}{|c|c|c|c|c|c|c|}
\hline Hydroperoxide 96 & $\mathrm{R}^{1}$ & $\mathrm{R}^{2}$ & $\mathrm{R}^{3}$ & M & Dioxolane 99-102 (yield, \%) & Alkene 103-107 (X, yield, \%) \\
\hline $\mathbf{a}$ & Me & $\mathrm{Me}$ & $\mathrm{Me}$ & $\mathrm{Ti}$ & $99(31)$ & - \\
\hline b & $\mathrm{Me}$ & $\mathrm{Me}$ & $\left(\mathrm{CH}_{2}\right)_{2} \mathrm{OMe}$ & Sn & $99(56)$ & - \\
\hline b & $\mathrm{Me}$ & $\mathrm{Me}$ & $\left(\mathrm{CH}_{2}\right)_{2} \mathrm{OMe}$ & $\mathrm{Ti}$ & $99(12)$ & $103(-\mathrm{OOH}, 23)$ \\
\hline c & \multicolumn{2}{|c|}{$\begin{array}{l}\text { 4-tert-butyl- } \\
\text { cyclohexylidene }\end{array}$} & $\mathrm{Me}$ & $\mathrm{Ti}$ & - & $104\left(-\mathrm{O}_{2}-, 31\right)$ \\
\hline c & \multicolumn{2}{|c|}{$\begin{array}{l}\text { 4-tert-butyl- } \\
\text { cyclohexylidene }\end{array}$} & $\mathrm{Me}$ & Sn & $100(42)$ & - \\
\hline d & \multicolumn{2}{|c|}{$\begin{array}{l}\text { 4-tert-butyl- } \\
\text { cyclohexylidene }\end{array}$} & $\left(\mathrm{CH}_{2}\right)_{2} \mathrm{OMe}$ & Sn & $100(59)$ & - \\
\hline e & $\mathrm{Me}$ & $\mathrm{BnOCH}_{2}$ & $\mathrm{Me}$ & $\mathrm{Ti}$ & $101(12)$ & $105(=0,62)$ \\
\hline f & $\mathrm{Bu}$ & $\mathrm{H}$ & $\mathrm{Me}$ & $\mathrm{Ti}$ & $102(7)$ & $106(\mathrm{OMe}, 63)$ \\
\hline g & $\mathrm{Bu}$ & $\mathrm{H}$ & $\left(\mathrm{CH}_{2}\right)_{2} \mathrm{OMe}$ & $\mathrm{Ti}$ & $102(15)$ & $\begin{array}{l}107\left(\mathrm{O}\left(\mathrm{CH}_{2}\right)_{2} \mathrm{OMe}\right. \\
\text { the yield was not determined })\end{array}$ \\
\hline
\end{tabular}




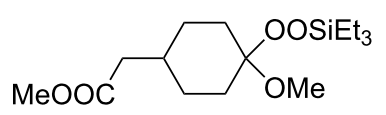

108<smiles>C=C1C2CC3CC1CC3C2</smiles>

109

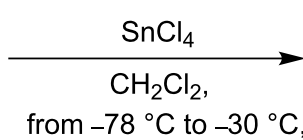

$12 \mathrm{~h}$

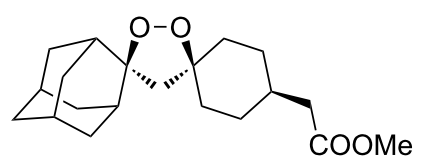

110

Scheme 28: $\mathrm{SnCl}_{4}$-catalyzed reaction of monotriethylsilylperoxyacetal 108 with alkene 109.

The reaction of trialkylsilylperoxyacetals with alkenes in the presence of Lewis acids also proceeds through the formation of peroxycarbenium ions. For example, the reaction of methyl 2-(4-methoxy-4-(triethylsilylperoxy)cyclohexyl)acetate (108) with 2-methyleneadamantane (109) produced adamantane-2-spiro-3', 8'-methoxycarbonylmethyl1 ',2'-dioxa-spiro[4.5]decane (110) in 40\% yield (Scheme 28) [258].

The use of easily accessible triethylsilylperoxyacetals $\mathbf{1 1 1}$ as the starting materials for the generation of silylperoxycarbe- nium ions 112 enabled the synthesis of 1,2-dioxolanes containing various functional groups 113-130 in good yields by the reactions with alkenes (Scheme 29, Table 10) $[88,90,259]$.

\subsection{Methods for the synthesis of 1,2-dioxolanes} from hydrogen peroxide and hydroperoxides

This section deals with reactions, in which hydrogen peroxide or hydroperoxides are used for the construction of the fivemembered peroxide ring. In all syntheses, the final (key) step involves the intramolecular cyclization of hydroperoxide with

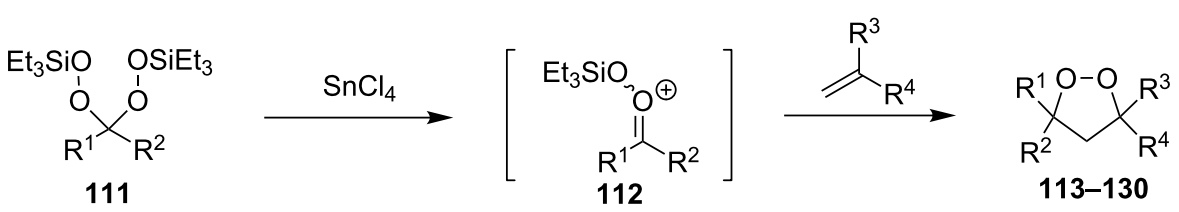

Scheme 29: $\mathrm{SnCl}_{4}$-catalyzed reaction of triethylsilylperoxyacetals 111 with alkenes.

Table 10: Structures and yields of 1,2-dioxolanes 113-130.

Structure

Yielda $^{\mathrm{a}}, \%$

Product

Structure

Yield $^{\mathrm{a}}$, \%

113<smiles>CC1(CCOc2ccccc2)C[C@]2(CC[C@@H](Br)CC2)OO1</smiles>

80<smiles>CC1CCCC2(C1)CC(C)(CCOc1ccccc1)OO2</smiles>

72

123

114<smiles>CC1(CCOc2ccccc2)CC(C)(CCc2ccccc2)OO1</smiles>

57

124<smiles>CC1(CCO)CC(C)(CCc2ccccc2)OO1</smiles>

67

125

117
122<smiles></smiles><smiles>CC1(CCO)C[C@]2(CC[C@@H](Br)CC2)OO1</smiles>
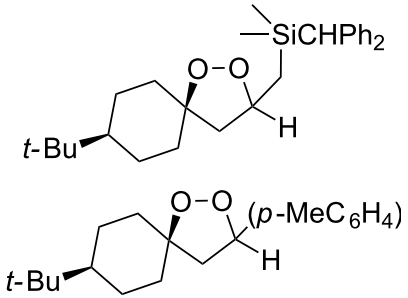

126<smiles>CC1(CC(C)(C)[Si](C)(C)c2ccccc2)C[C@]2(CC[C@H](C(=O)c3ccccc3)CC2)OO1</smiles> 
Table 10: Structures and yields of 1,2-dioxolanes 113-130. (continued)

118<smiles>CCOC(=O)CCC1(C)CC2(CCC(C(C)(C)C)CC2)OO1</smiles>

34<smiles>CC1(CCOCc2ccccc2)CC2(CCCCC2)OO1</smiles>

46

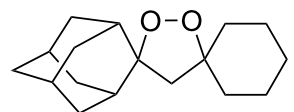

74

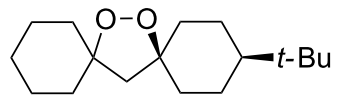

127<smiles>CC1CCC2(CC1)CC(C)(CCOc1ccccc1)OO2</smiles>

128<smiles>CC1CCCC2(C1)CC(C)(CCO)OO2</smiles>
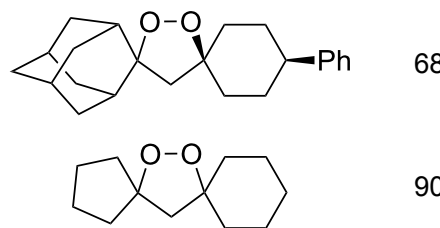

90

aReagents and conditions: $\mathrm{SnCl}_{4}\left(1.0-2.0\right.$ equiv), alkene (1.0-3.0 equiv), $\mathrm{CH}_{2} \mathrm{Cl}_{2}$, from $-78{ }^{\circ} \mathrm{C}$ to $25^{\circ} \mathrm{C}, 2-24 \mathrm{~h}$.

the attack on the electrophilic center (an activated double bond or a carbon atom of a keto or ester group).

The desilylation of tert-butyldimethylsilylperoxy ketones 131a,b with HF followed by cyclization and subsequent reaction with monomethylethylene glycol afforded dioxolanes 132a,b in 75 and $88 \%$ yield, respectively. The intermediate hydroxydioxolanes 131'a,b were used in the second step without isolation (Scheme 30) [260]. A series of analogues of plakinic acids were synthesized by the modification of the peroxyketal moiety of dioxolanes 132a and 132b [260].
The monoperoxy ketal moiety of 4-(2-methoxypropan-2ylperoxy)nonan-2-one (133) was used for the generation of the hydroperoxide group. The intramolecular cyclization afforded 3-methyl-5-pentyl-1,2-dioxolan-3-ol (134), which could be easily reacted with monomethylethylene glycol to form 3-(2methoxyethoxy)-3-methyl-5-pentyl-1,2-dioxolane (135). Allylation of the latter produced 3-allyl-3-methyl-5-pentyl-1,2-dioxolane (136) in 47\% yield (Scheme 31) [261].

The asymmetric peroxidation of methyl vinyl ketones 137a-e with 9-amino-9-deoxyepiquinine $\mathbf{1 3 8}$ and $\mathrm{CCl}_{3} \mathrm{COOH}$ afforded

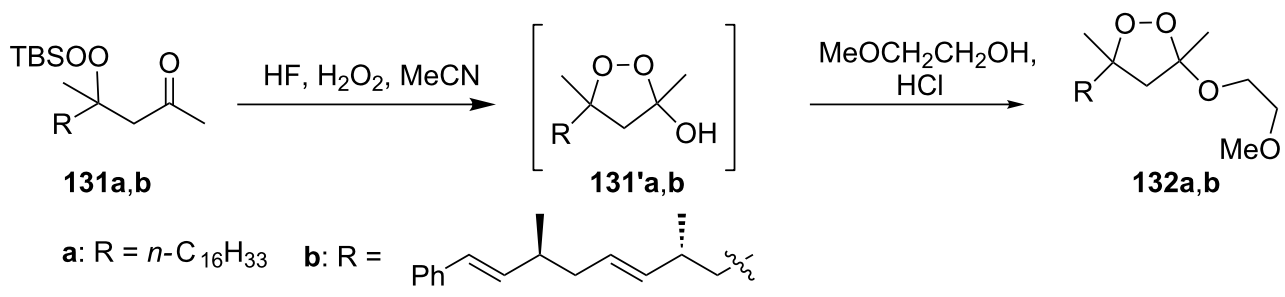

Scheme 30: Desilylation of tert-butyldimethylsilylperoxy ketones $131 \mathbf{a}, \mathbf{b}$ followed by cyclization.

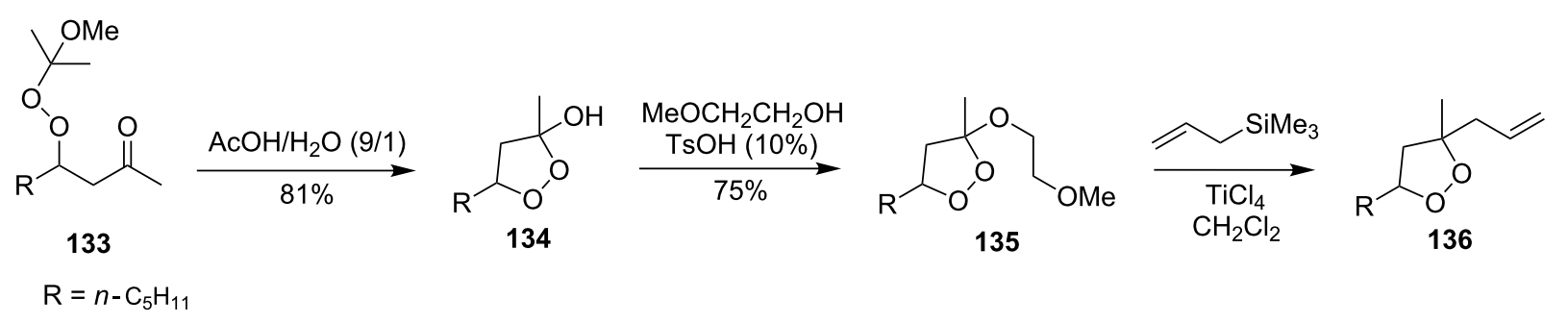




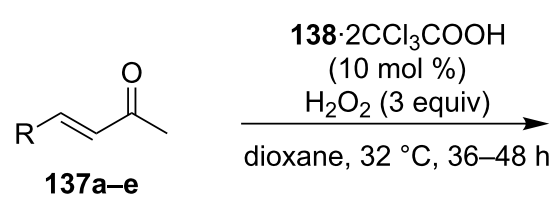

$137 \mathrm{a}-\mathrm{e}$<smiles>[R]C1CC(C)(O)OO1</smiles>

$139 a-e$

$R$<smiles>COc1ccc2nccc(C(N)C3CC4CCN3CC4)c2c1</smiles>

138

139a

$139 \mathrm{~b}$

139c

$139 d$

$\mathrm{iC}_{6} \mathrm{H}_{13} \quad 65$

$\mathrm{PhCH}_{2} \mathrm{CH}_{2} \quad 68$

$\mathrm{CH}_{2}=\mathrm{CHCH}_{2} \quad 69$

139 e

$\mathrm{iBu}$

cyclohexyl

hydroxydioxolanes 139a-e with high enantiomeric excess (ee 94-95\%) (Scheme 32) [262].

The Kobayashi synthesis of 1,2-dioxolanes represents an intramolecular version of the Michael reaction, in which the hydroperoxide group acts as the nucleophile. Generally, the reaction is performed in fluorinated alcohols $\left(\mathrm{CF}_{3} \mathrm{CH}_{2} \mathrm{OH}\right.$ or $\left.\left(\mathrm{CF}_{3}\right)_{2} \mathrm{CHOH}\right)$ in the presence of diethylamine or, in some cases, of cesium hydroxide. Initially, the method was proposed for the synthesis of the 1,2-dioxane moiety (examples are considered in the corresponding section) [263]. However, it was shown that this method is also applicable to the preparation of structurally complex 1,2-dioxolanes, such as methyl 2-(5-(5methylfuran-2-yl)-1,2-dioxolan-3-yl)acetate (141) from the furan derivative (E)-methyl 5-hydroperoxy-5-(5-methylfuran-2yl)pent-2-enoate (140) (Scheme 33) [264].

A simple method was developed for the synthesis of cyclopropane-containing oxodioxolanes $143 \mathbf{a}-\mathbf{j}$ and is based on the hydroperoxidation of tertiary alcohols $\mathbf{1 4 2} \mathbf{a}-\mathbf{j}$ in an acidic medium followed by cyclization of the intermediate hydroperoxides through the ester group (Scheme 34) [265].

This method allows for the use of a nonhazardous $30 \%$ hydrogen peroxide solution. However, the authors mentioned that structurally similar tertiary alcohols, without a cyclopropane substituent, are inert under the reported conditions.<smiles>COC(=O)C=CCC(O)c1ccc(C)o1</smiles>

140

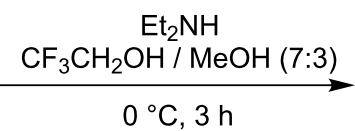

$0{ }^{\circ} \mathrm{C}, 3 \mathrm{~h}$

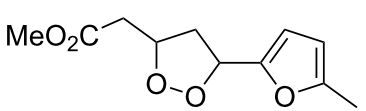

$141,17 \%$

Scheme 33: $\mathrm{Et}_{2} \mathrm{NH}$-catalyzed intramolecular cyclization.

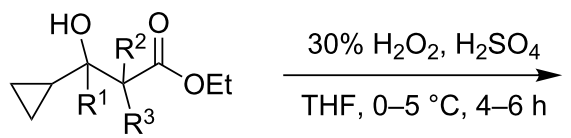

$142 a-j$<smiles>[R]C1([R])C(=O)OOC1([R])C1CC1</smiles>

$143 a-j$

$\begin{array}{lcccc} & \mathrm{R}^{1} & \mathrm{R}^{2} & \mathrm{R}^{3} & \text { Yield, \% } \\ \text { 143a } & \mathrm{Me} & \mathrm{H} & \mathrm{H} & 80 \\ \text { 143b } & \mathrm{Me} & \mathrm{H} & \mathrm{Me} & 38 \\ \text { 143c cyclopropyl } & \mathrm{H} & \mathrm{H} & 69 \\ \text { 143d cyclopropyl } & \mathrm{H} & \mathrm{Me} & 39 \\ \text { 143e cyclopropyl } & \mathrm{H} & \mathrm{Et} & 35\end{array}$

$\begin{array}{ll} & \mathrm{R}^{1} \\ 143 f & \mathrm{Ph} \\ 143 \mathrm{~g} & 4-\text {-chlorophenyl } \\ 143 \mathrm{~h} & \mathrm{Me} \\ 143 \mathrm{i} & \mathrm{Me} \\ 143 \mathrm{j} & \text { cyclopropyl }\end{array}$

$\begin{array}{ccc}\mathrm{R}^{2} & \mathrm{R}^{3} & \text { Yield, \% } \\ \mathrm{H} & \mathrm{H} & 42 \\ \mathrm{H} & \mathrm{H} & 55 \\ \mathrm{H} & \mathrm{Et} & 52 \\ \mathrm{Me} & \mathrm{Me} & 33 \\ \mathrm{Me} & \mathrm{Me} & 30\end{array}$


Haloperoxidation reaction that is accompanied by intramolecular ring closure represents another version of the cyclization reaction. For example, the reaction of bromine with unsaturated hydroperoxide 146 (produced by reaction of 1,4,5,8-tetrahydronaphthalene (144) with singlet oxygen via the formation of 4a-hydroperoxy-1,4,4a,5-tetrahydronapthalene (145) gives hydroperoxide-containing bromonium cation 147 as the intermediate, which undergoes cyclization to form 1,2-dioxolanecontaining 7-bromo-4,5,10,11-tetraoxatetracyclo[7.2.2.1 $\left.1^{3,6} \cdot 0^{3,9}\right]$ tetradec-12-ene (148) (Scheme 35).

The cyclization occurs selectively because the hydroperoxide group in intermediate $\mathbf{1 4 7}$ attacks only one of two possible electrophilic carbon centers [266].

\subsection{1,2-Dioxolane ring formation through oxidation of the allylic position}

1,2-Dioxolane-containing compounds $\mathbf{1 5 0 a - d}$ were synthesized by the oxidation of triterpenes $149 \mathbf{a}-\mathbf{d}$ with $\mathrm{Na}_{2} \mathrm{Cr}_{2} \mathrm{O}_{7} / N$ hydroxysuccinimide (Scheme 36 ). The resulting compounds ex- hibit antitumor activity comparable with that of betulinic acid [175-177].

\subsection{Structural modifications, in which the 1,2-diox- olane ring remains intact}

The possibility of performing the Curtius and Wolff rearrangements to form 1,2-dioxolane ring-retaining products was exemplified by the synthesis of ethyl (3,5,5-trimethyl-1,2-dioxolan-3yl)methylcarbamate (152) and methyl 3-(3,5,5-trimethyl-1,2dioxolan-3-yl)propanoate (154) (through formation of stable diazodioxolane 153) from 2-(3,5,5-trimethyl-1,2-dioxolan-3yl)acetic acid (151) (Scheme 37) [267].

Dioxolane 155 that contains a free hydroxy group was synthesized by the oxidative desilylation of silicon-containing peroxide 124 with $n$ - $\mathrm{Bu}_{4} \mathrm{NF}$ and $\mathrm{H}_{2} \mathrm{O}_{2}$ (Scheme 38) [259].

Dioxolane 158 with the aminoquinoline antimalarial pharmacophore was synthesized in two steps by the oxidation of alcohol 156 with $\mathrm{H}_{5} \mathrm{IO}_{6} / \mathrm{RuCl}_{3}$ followed by amidation of the

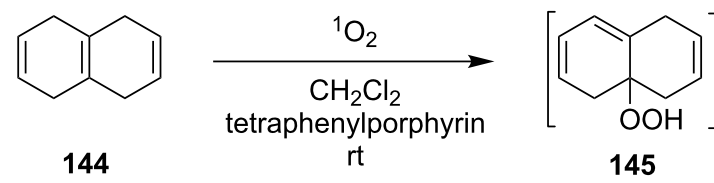

145

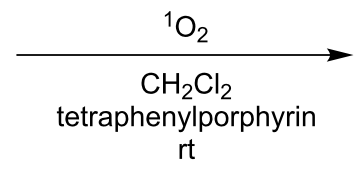

$\mathrm{rt}$

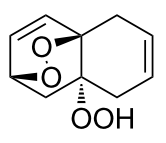

$146,80 \%$

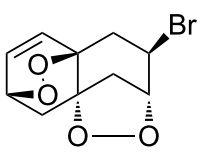

$148,80 \%$

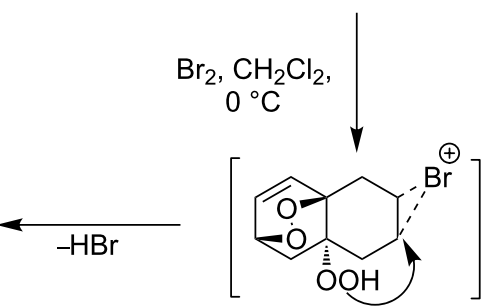

147

Scheme 35: Haloperoxidation accompanied by intramolecular ring closure.

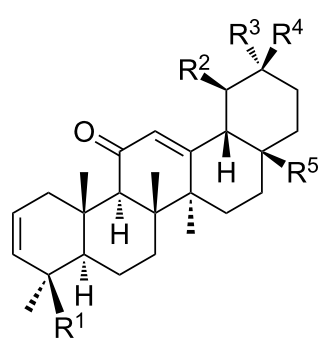

$149 a-d$

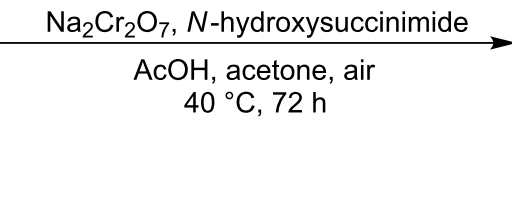
$40^{\circ} \mathrm{C}, 72 \mathrm{~h}$

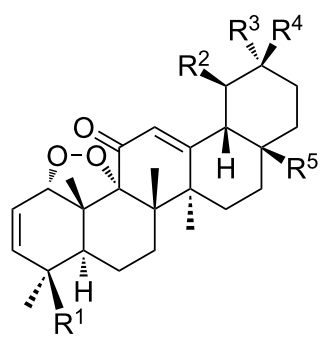

$150 a-d$

a $R^{1}, R^{3}, R^{5}=M e ; R^{4}=$ coOMe; $R^{2}=H ; 53 \%$

b $R^{1}, R^{2}, R^{3}=M e ; R^{5}=$ COOMe; $R^{4}=H ; 48 \%$

c $R^{1}, R^{3}, R^{4}=M e ; R^{5}=$ COOMe; $R^{2}=H ; 45 \%$

d $R^{2}, R^{3}, R^{5}=M e ; R^{4}=H ; R^{1}=$ COOMe $; 45 \%$ 


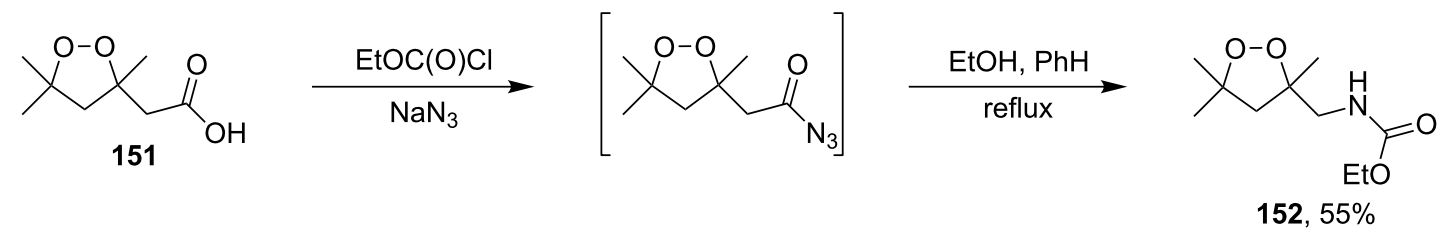

151

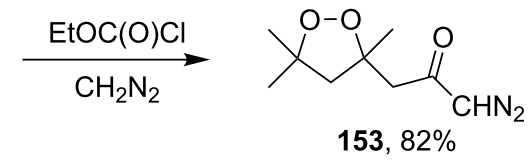

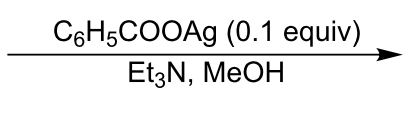

$\mathrm{Et}_{3} \mathrm{~N}, \mathrm{MeOH}$

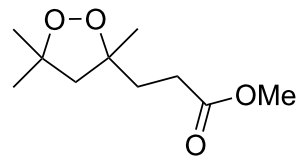

$154,99 \%$

Scheme 37: Curtius and Wolff rearrangements to form 1,2-dioxolane ring-retaining products.<smiles>CC(C)(C)C1CCC2(CCC(CCCCC(c3ccccc3)c3ccccc3)OO2)OO1</smiles>

124

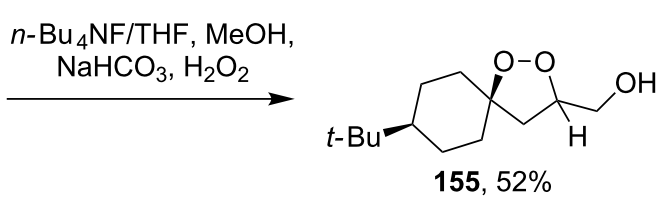

$155,52 \%$

Scheme 38: Oxidative desilylation of peroxide 124.

acid 157 (Scheme 39) [88]. It was shown that compound 158 exhibits antimalarial activity comparable with that of artemisinin [88].

Plakinic acids belong to a large family of natural products, which were shown to be highly cytotoxic toward cancer cells and fungi. Diastereomers of plakinic acid A, 162a and 162b were synthesized starting from dioxolane $((R)-3$ ((2R,3E,6S,7E)-2,6-dimethyl-8-phenylocta-3,7-dienyl)-5-(2methoxyethoxy)-3,5-dimethyl-1,2-dioxolane) (159) [260]. In the first step, dioxolane 159 was treated with (1-(ethylthio)vinyloxy)-trimethylsilane in the presence of $\mathrm{TiCl}_{4}$ to obtain $S$-ethyl 2-((R)-5-((2R,3E,6S,7E)-2,6-dimethyl-8-phenylocta-3,7dienyl)-3,5-dimethyl-1,2-dioxolan-3-yl)-ethanethioate (160). The subsequent reaction with sodium methoxide in methanol produced the corresponding esters $161 \mathrm{a}$ and $161 \mathrm{~b}$, which were hydrolyzed to prepare the target plakinic acids (Scheme 40).

\section{Synthesis of 1,2,4-trioxolanes (ozonides)}

The currently most widely used methods for the synthesis of 1,2,4-trioxolanes are based on reactions of ozone with unsaturated compounds, such as the ozonolysis of alkenes, the crossozonolysis of alkenes with carbonyl compounds, and the crossozonolysis of O-alkylated oximes in the presence of carbonyl compounds (Griesbaum coozonolysis).

\subsection{Ozonolysis of alkenes}

According to the mechanism proposed by R. Criegee [268,269] the ozonolysis of alkenes $\mathbf{1 6 3}$ involves several steps: the 1,3dipolar cycloaddition of ozone to the double bond to form

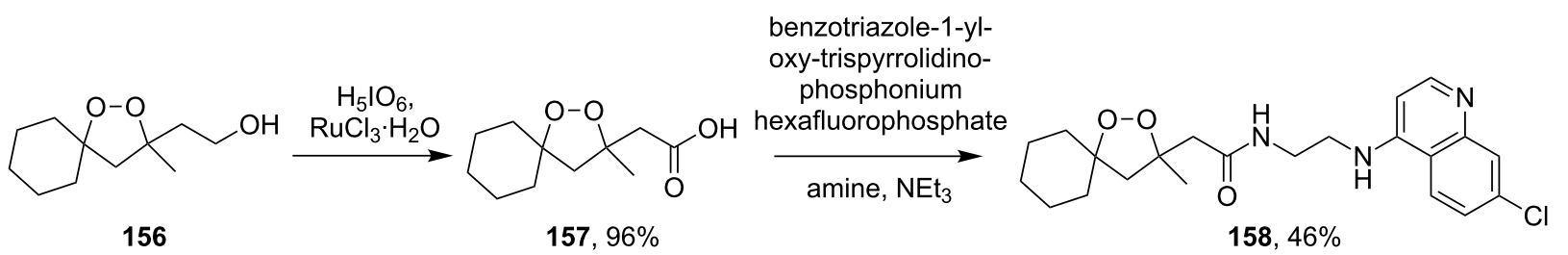



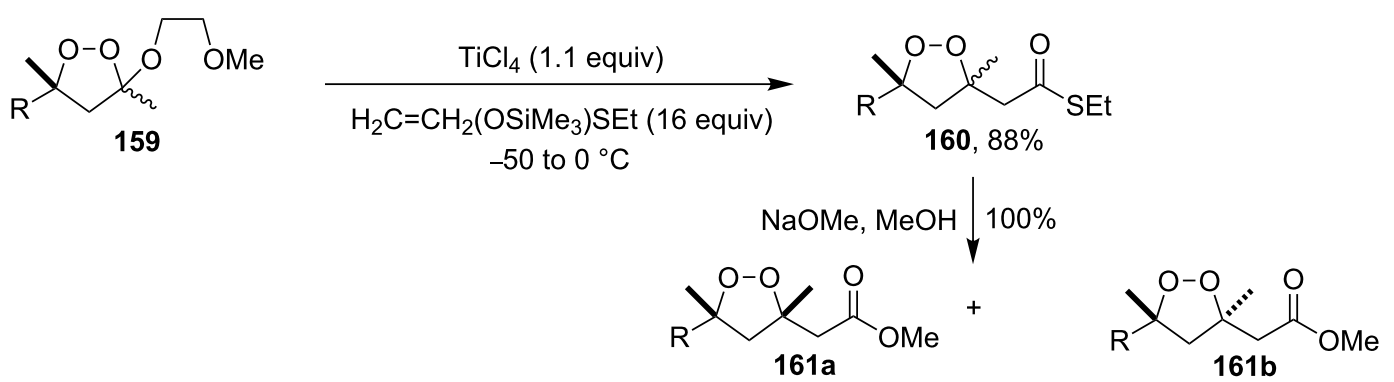

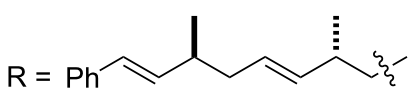

$\mathrm{LiOH}, 30 \% \mathrm{H}_{2} \mathrm{O}_{2}$,

THF

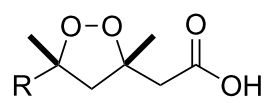

162a, $92 \%$
$\mathrm{LiOH}, 30 \% \mathrm{H}_{2} \mathrm{O}_{2}$,

THF<smiles>[R]C1(C)C[C@](C)(CC(=O)O)OO1</smiles>

162b, $91 \%$

Scheme 40: Diastereomers of plakinic acid A, 162a and 162b.

unstable 1,2,3-trioxolane 164 (so-called molozonide) that is followed by its decomposition to a peroxycarbenium ion and a carbonyl compound (Criegee intermediates). The 1,3-dipolar cycloaddition of the intermediates with each other form the 1,2,4-trioxolane 165 (Scheme 41, Table 11). Generally, the ozonolysis is performed in aprotic solvents at low temperatures and in some cases, on polymeric substrates. Since various compounds containing a $\mathrm{C}=\mathrm{C}$ group are easily available, a wide range of functionalized 1,2,4-trioxolanes can be synthesized in moderate to high yields.

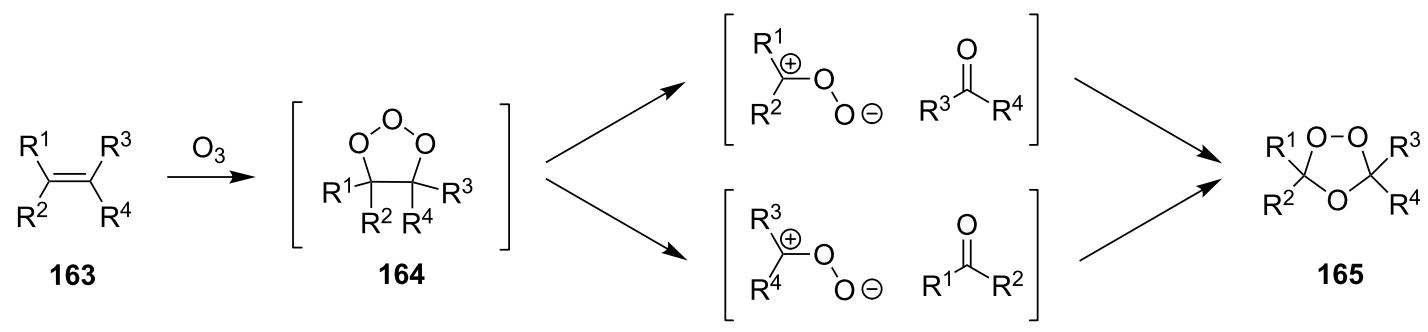

Criegee intermediates

Scheme 41: Ozonolysis of alkenes.

Table 11: Examples of 1,2,4-trioxolanes produced by the ozonolysis of alkenes.

Alkene 163


Table 11: Examples of 1,2,4-trioxolanes produced by the ozonolysis of alkenes. (continued)

$$
\begin{array}{ll} 
& \text { hexane, }-78{ }^{\circ} \mathrm{C} \\
&
\end{array}
$$<smiles>C=CC[C@](C)(NCc1ccccc1)[C@@H](OC)C(C)[Ge](C)(C)C</smiles>

isooctane $/ \mathrm{CCl}_{4},-78^{\circ} \mathrm{C}, 1 \mathrm{~h}$<smiles>C=CCC1CCCC(=O)C1</smiles><smiles>C=CCC1CCC(=O)C1</smiles>

$\mathrm{CH}_{2} \mathrm{Cl}_{2},-78{ }^{\circ} \mathrm{C}$

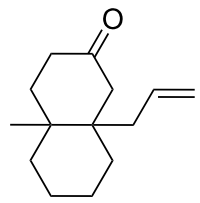

$\mathrm{CH}_{2} \mathrm{Cl}_{2},-78^{\circ} \mathrm{C}$<smiles>C=CCC(C)(C)CC(C)=O</smiles>

$\mathrm{CH}_{2} \mathrm{Cl}_{2},-78{ }^{\circ} \mathrm{C}$<smiles>C=CCCCC(C)=O</smiles>

$\mathrm{CH}_{2} \mathrm{Cl}_{2},-78{ }^{\circ} \mathrm{C}$

$$
\begin{aligned}
& \mathrm{CH}_{2} \mathrm{Cl}_{2},-78^{\circ} \mathrm{C} \\
& \langle\mathrm{O}\rangle=\begin{array}{l}
\text { pentane, } \\
-78^{\circ} \mathrm{C}
\end{array}
\end{aligned}
$$

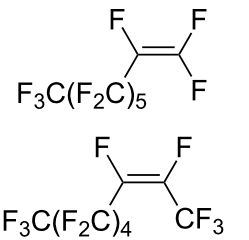<smiles>FC(=C(F)C(F)(F)C(F)(F)C(F)(F)C(F)(F)F)C(F)(F)C(F)(F)F</smiles>
freon- $113,15-20^{\circ} \mathrm{C}, 2 \mathrm{~h}$<smiles>[CH2]C1OOC(c2ccccc2)O1</smiles><smiles>c1ccc([C@@H]2OCOO2)cc1</smiles><smiles>CC1(c2ccccc2)OCOO1</smiles>
61<smiles>CO[C@H]([C@@H](C)OC)[C@](C)(CC1([O-])OCOO1)[N+](=O)[O-]</smiles><smiles>O=C1CCCC(CC2OCOO2)C1</smiles><smiles>O=C1CCC(CC2OCOO2)C1</smiles><smiles>CC12CCCCC1(CC1OCOO1)CC(=O)CC2</smiles><smiles>CC(=O)CC(C)(C)CC1OCOO1</smiles><smiles>CC(=O)CCCC1OCOO1</smiles><smiles>c1ccc(CCC2OCOO2)cc1</smiles><smiles>CC1(COc2ccccc2)OCOO1</smiles>
63<smiles>FC(C(F)(F)F)C(F)(F)C1(F)OOC(F)(F)O1</smiles><smiles>FC1(F)OO[Ge](F)(C(F)(F)C(F)(F)F)O1</smiles><smiles>FC(F)(F)C(F)(F)C(F)(F)C1(F)OO[Ge](F)(C(F)(F)C(F)(F)F)O1</smiles>

The yield was not determined

[275]

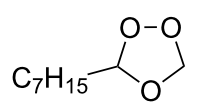

$$
\mathrm{C}_{7} \mathrm{H}_{15}=\quad \mathrm{CH}_{2} \mathrm{Cl}_{2},-78^{\circ} \mathrm{C}
$$


Table 11: Examples of 1,2,4-trioxolanes produced by the ozonolysis of alkenes. (continued)<smiles>CC1=C(C)CC(C)=C(C)C1</smiles>

polymer-based, $-78^{\circ} \mathrm{C}, 8 \mathrm{~h}$<smiles>CC1=C(C)CC2(C)OC2(C)C1</smiles>

polymer-based, $-78^{\circ} \mathrm{C}, 3 \mathrm{~h}$<smiles>c1cc2ccc3cccc4ccc(c1)c2c34</smiles>

$\mathrm{CH}_{2} \mathrm{Cl}_{2},-70{ }^{\circ} \mathrm{C}$

$\left(\mathrm{F}_{3} \mathrm{C}\right)_{2} \mathrm{FCFC}=\mathrm{CFCF}_{3} \quad$ without solvent, -133 to $-43^{\circ} \mathrm{C}$

1) $\mathrm{CH}_{2} \mathrm{Cl}_{2}$,

$-78{ }^{\circ} \mathrm{C}, 15 \mathrm{~min}$.

2) $\mathrm{Me}_{2} \mathrm{~S}, \mathrm{rt}, 6 \mathrm{~h}$

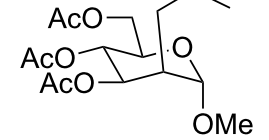

$\mathrm{Me}_{2} \mathrm{~S}, \mathrm{rt}, 6 \mathrm{~h}$

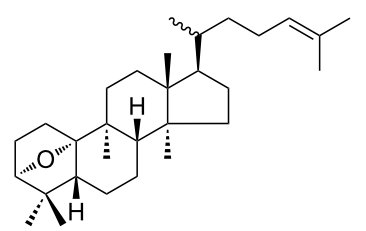

hexane,

$-78^{\circ} \mathrm{C}, 30 \mathrm{~min}$<smiles>C=CC[C@H]1C(=O)N([R6](=O)OC(C)(C)C)[C@@H]1C</smiles>

$\mathrm{CH}_{2} \mathrm{Cl}_{2},-78^{\circ} \mathrm{C}, 20 \mathrm{~min}$<smiles>C=CC(C)CC(C)OC(C)CCCC</smiles>

$\mathrm{CH}_{2} \mathrm{Cl}_{2},-78^{\circ} \mathrm{C}, 2 \mathrm{~h}$<smiles>COC=C1CCOC1=O</smiles>

$\mathrm{CDCl}_{3},-65^{\circ} \mathrm{C}$<smiles>COC(=O)C1=CCCCC1</smiles>

$\mathrm{CFCl}_{3},-70^{\circ} \mathrm{C}$<smiles>C=CCC1C(=O)C(OC)OC2COC(c3ccccc3)O[C@@H]21</smiles><smiles>CC(=O)CC1(C)OOC(C)(CC(C)=O)O1</smiles>

[276]<smiles></smiles>

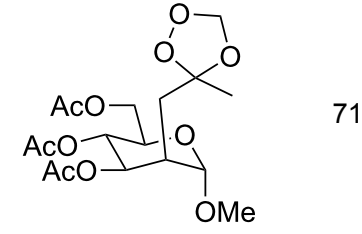

71

6

[280]<smiles>CC1OC2(C)CCC1C2</smiles><smiles>C[C@H]1[C@H](CC2OCOO2)C(=O)N1C(=O)OC(C)(C)C</smiles>

The yield was not determined

[281]<smiles>CC(C)CO[C@@H](C)CC(C)C1OCOO1</smiles><smiles>CC(C)[18O]c1ccccc1</smiles>

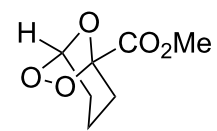

100<smiles>CO[C@H]1O[C@@H]2COC(c3ccccc3)O[C@@H]2[C@H](CC2OCOO2)C1=O</smiles> 
Table 11: Examples of 1,2,4-trioxolanes produced by the ozonolysis of alkenes. (continued)<smiles>C=CC[C@]1(C)C(=O)C(OC)OC2COC(c3ccccc3)OC21</smiles>

$\mathrm{CH}_{2} \mathrm{Cl}_{2},-78^{\circ} \mathrm{C}, 1 \mathrm{~h}$<smiles></smiles>

$$
\mathrm{R}=\mathrm{Me}, \mathrm{Et}, \mathrm{Pr},
$$

iPr, iBu, E<smiles>C=CCCC1(O)CCc2ccccc2O1</smiles><smiles>CC1=CCC(C2COC(C)(C)OC2)C(=O)C1</smiles><smiles>[C+]=[PbH2]</smiles><smiles>C=CCCOC(C)=O</smiles><smiles>C=CCC[C@@H](OCc1ccccc1)C(O)C(F)F</smiles>
$-78^{\circ} \mathrm{C}$

$\mathrm{Et}_{2} \mathrm{O} / \mathrm{CH}_{3} \mathrm{OH},-78^{\circ} \mathrm{C}$

$\mathrm{CH}_{2} \mathrm{Cl}_{2},-78^{\circ} \mathrm{C}$

$\mathrm{CH}_{2} \mathrm{Cl}_{2}, 0^{\circ} \mathrm{C}$

$\mathrm{H}_{2} \mathrm{O} / \mathrm{CH}_{2} \mathrm{Cl}_{2}$,
$0{ }^{\circ} \mathrm{C}$

1) $\mathrm{SiO}_{2}$,

$-78^{\circ} \mathrm{C}$; pentane,

2) $\mathrm{Me}_{2} \mathrm{~S}, \mathrm{MeOH}$<smiles>CO[C@H]1O[C@@H]2CO[C@@H](c3ccccc3)O[C@H]2[C@](C)(C[C@@H]2OCOO2)C1=O</smiles>

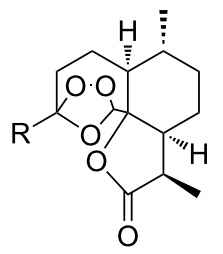

$$
\mathrm{R}=\mathrm{Me}, \mathrm{Et}, \mathrm{Pr},
$$
iPr, iBu, E<smiles>OC1(CCC2OCO2)CCc2ccccc2O1</smiles><smiles>CC1(C)OCC(C2CC3OOC(C)(CC2=O)O3)CO1</smiles><smiles>[PH3+][PH2+]C1OCOO1</smiles><smiles>CC(C)(C)OC[CH]C1OCOO1</smiles><smiles>OC(CCC1OCOO1)C(O)C(F)F</smiles>

\subsection{Cross-ozonolysis of alkenes with carbonyl com-} pounds

The peroxycarbenium ion produced by the decomposition of 1,2,3-trioxolane (molozonide) can react with externally introduced carbonyl compounds to form the corresponding $1,2,4$ - trioxolanes. The pathway of decomposition of 1,2,3-trioxolanes is determined by the structure of the starting alkene 166. In some cases, a high selectivity of the formation of cross-ozonolysis products 1,2,4-trioxolanes (ozonides) 167, can be achieved (Scheme 42, Table 12).

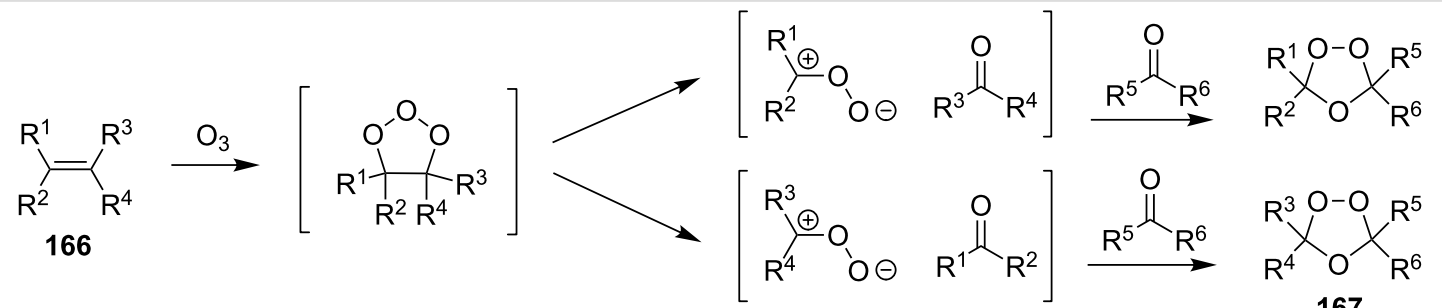

Scheme 42: Cross-ozonolysis of alkenes 166 with carbonyl compounds. 
Table 12: Examples of 1,2,4-trioxolanes synthesized by the cross-ozonolysis of alkenes in the presence of carbonyl compounds.

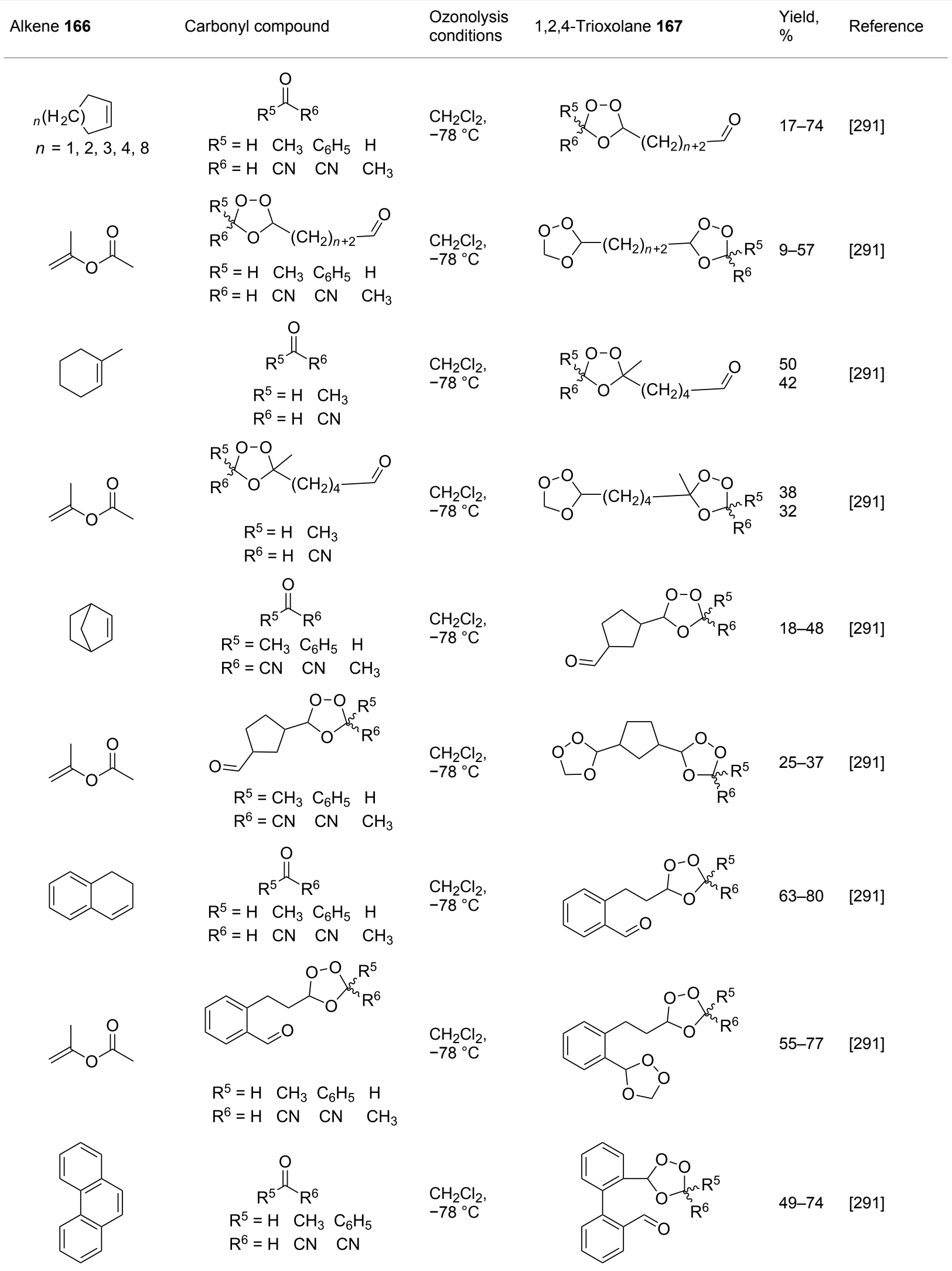




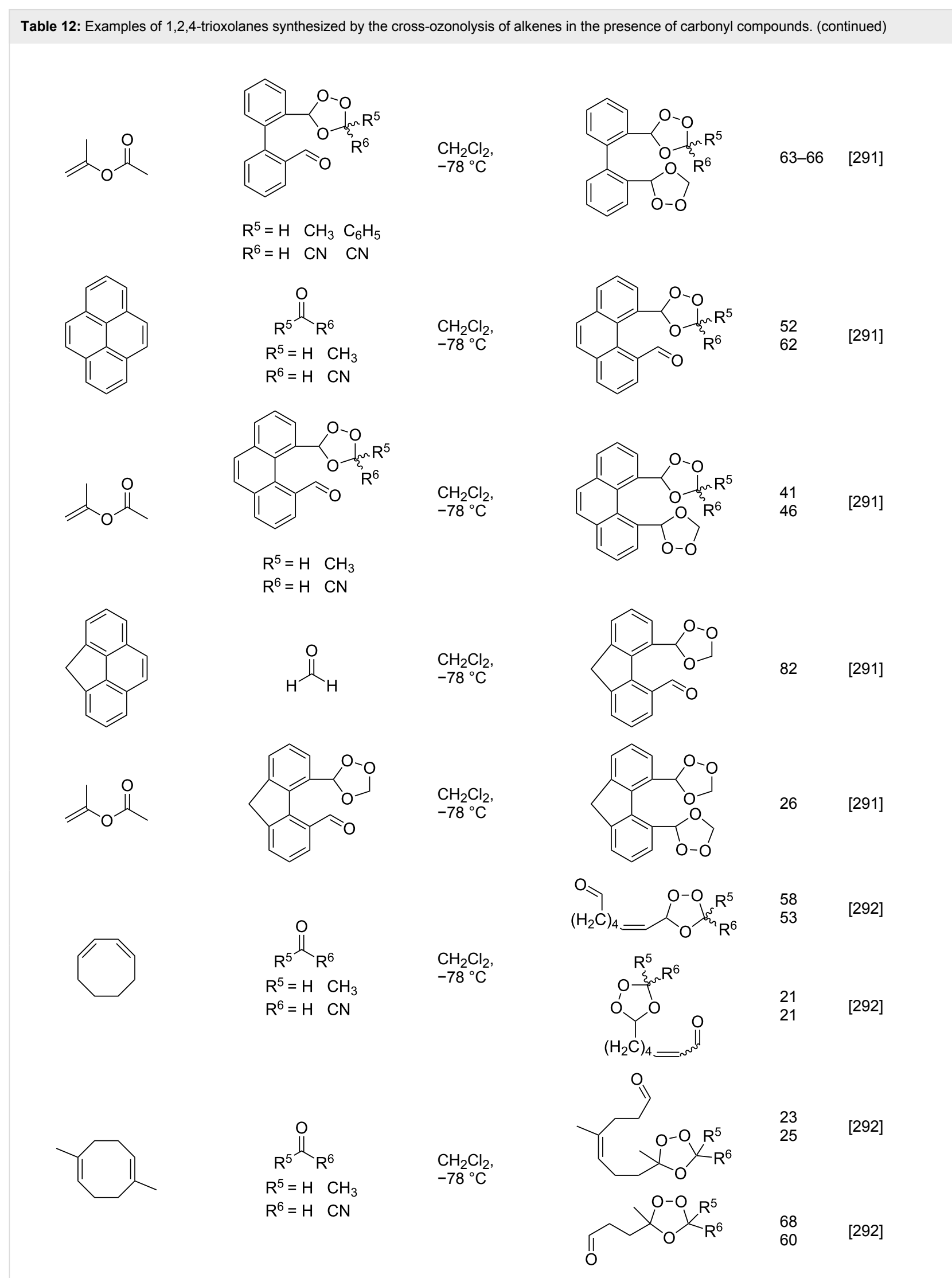


Table 12: Examples of 1,2,4-trioxolanes synthesized by the cross-ozonolysis of alkenes in the presence of carbonyl compounds. (continued)<smiles>C1=CCCC=CCC1</smiles><smiles>[R6]C([R6])=O</smiles>

$\mathrm{R}^{5}=\mathrm{H} \quad \mathrm{CH}_{3}$ $\mathrm{R}^{6}=\mathrm{H} \quad \mathrm{CN}$

$\mathrm{CH}_{2} \mathrm{Cl}_{2}$, $-78^{\circ} \mathrm{C}$<smiles>O=C(c1ccccc1)C(F)(F)F</smiles>

\section{$\mathrm{Et}_{2} \mathrm{O}$,}

$\mathrm{Et}_{2} \mathrm{O}$, $-70{ }^{\circ} \mathrm{C}$<smiles>O=C(c1ccccc1)C(F)(F)F</smiles>

$-70^{\circ} \mathrm{C}$<smiles>CCC=O</smiles>

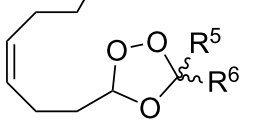

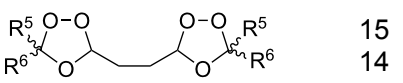
$\overbrace{\mathrm{O}^{2}}^{\mathrm{O}}{ }_{27}^{\mathrm{O}}$

$\stackrel{1}{0}$

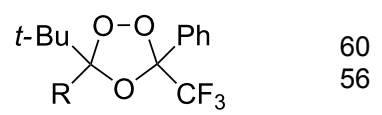

$\mathrm{R}=\mathrm{Me}, \mathrm{iPr}$<smiles>[R]C1([R])CCCC([R])([R])C1=C</smiles>

a $\mathrm{R}^{1}=\mathrm{H} ; \mathrm{R}^{2}=\mathrm{H}$;

$\mathrm{R}^{3}=\mathrm{H}$

b $\mathrm{R}^{1}=\mathrm{H}$;

$\mathrm{R}^{2}=-\left(\mathrm{CH}_{2}\right)_{4^{-}}=\mathrm{R}^{3}$

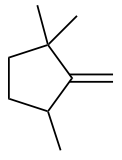

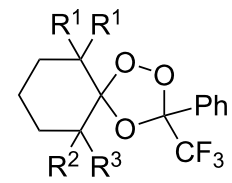

\section{9}<smiles>CC1CCC(C)(C)C12OOC(c1ccccc1)(c1ccccc1)C2(C)C</smiles>

[293]

3]

59

[293]
For the ozonolysis of the bicyclic cyclohexenone, $2,3,4,5,6,7,8,9,10,11,12,13,14,15$-tetradecahydro- $1 H$ benzo[13]annulen-1-one (168), two reaction pathways can be proposed through intermediate $\mathbf{1 6 9}$ to form ozonides $\mathbf{1 7 0}$ and 171. It appeared that the reaction gave only 16,17,18-trioxatricyclo[10.3.2.11,12] octadecan-2-one $\mathbf{1 7 1}$ as two isomers, with the anti isomer in $60 \%$ and the syn isomer in $10 \%$ yield
(Scheme 43) [294]. The structures of these compounds were established by X-ray diffraction [294].

The cross-ozonolysis of enol ethers $\mathbf{1 7 2 a}, \mathbf{b}$ with cyclohexanone enabled the synthesis of 1,2,4-trioxolanes 173a,b containing the easily oxidizable $\mathrm{C}-\mathrm{H}$ fragment in the third position (Scheme 44) [256].<smiles>CCCCCCC1=C(CCC)CCCC1=O</smiles>

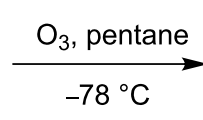

168

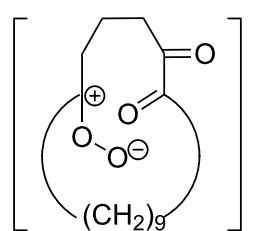

169

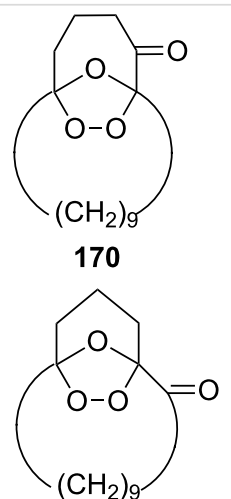

171 


$$
\begin{aligned}
& \underset{\mathrm{HMe}}{\mathrm{R}} \frac{\mathrm{O}}{-70^{\circ} \mathrm{C}} \\
& \text { 172a } \mathrm{R}=\mathrm{C}_{8} \mathrm{H}_{17} \quad 173 \mathrm{a}, 47 \% \\
& 172 b \mathrm{~b}=\mathrm{Ph} \quad 173 \mathrm{~b}, 65 \%
\end{aligned}
$$

Scheme 44: Cross-ozonolysis of enol ethers $172 a, b$ with cyclohexanone.
2.3. Cross-ozonolysis of O-alkyl oximes in the presence of carbonyl compounds (Griesbaum co-ozonolysis)

In 1995, K. Griesbaum and co-workers reported a new type of cross-ozonolysis [295]. This method enables the synthesis of tetrasubstituted ozonides $\mathbf{1 7 6}$ by an ozone-mediated reaction of O-alkyl oximes 174 with ketones 175 (Scheme 45, Table 13). The selective synthesis of ozonides has attracted great interest because it allows the preparation of compounds exhibiting high antiparasitic activity.

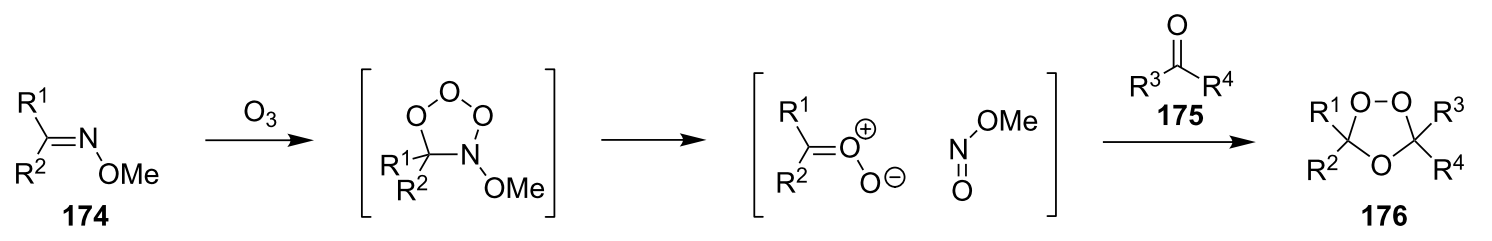

Scheme 45: Griesbaum co-ozonolysis.

Table 13: Examples of ozonides (1,2,4-trioxolanes) synthesized by the Griesbaum method.

$\begin{array}{llll}\text { Oxime } 174 & \text { Ketone } 175 & \begin{array}{l}\text { Ozonolysis } \\ \text { conditions }\end{array} & \text { 1,2,4-Trioxolane } 176 \quad \text { Yield, \% }\end{array}$<smiles>CON=C1CCCCC1</smiles>

$$
\mathrm{R}^{1} \stackrel{\mathrm{O}}{\mathrm{L}_{\mathrm{R}}^{2}}
$$

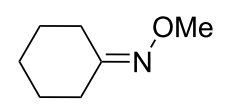

$$
\begin{aligned}
& \mathrm{R}^{1}=-\left(\mathrm{CH}_{2}\right)_{4^{-}}=\mathrm{R}^{2} \\
& \mathrm{R}^{1}=-\left(\mathrm{CH}_{2}\right)_{5^{-}}=\mathrm{R}^{2} \\
& \mathrm{R}^{1}=-\left(\mathrm{CH}_{2}\right)_{6^{-}}=\mathrm{R}^{2} \\
& \mathrm{R}^{1}=\mathrm{CH}_{3} ; \mathrm{R}^{2}=\mathrm{Ph} \\
& \mathrm{R}^{1}=\mathrm{C}_{4} \mathrm{H}_{9} ; \mathrm{R}^{2}=\mathrm{C}_{4} \mathrm{H}_{9}
\end{aligned}
$$<smiles>[R]C1([R])OOC2(CCCCC2)O1</smiles>
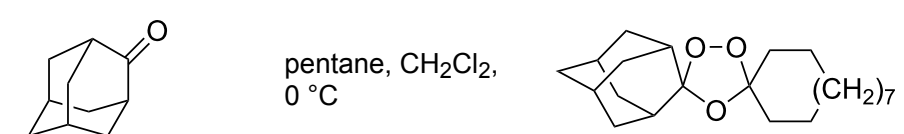

54
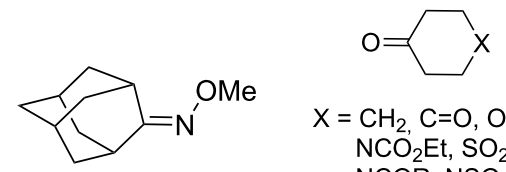

$\mathrm{X}=\mathrm{CH}_{2}, \mathrm{C}=\mathrm{O}, \mathrm{O}$, $\mathrm{NCO}_{2} \mathrm{Et}, \mathrm{SO}_{2}, \mathrm{NCO}_{2} t-\mathrm{Bu}$

pentane, $\mathrm{CH}_{2} \mathrm{Cl}_{2}$, $\mathrm{NCOR}, \mathrm{NSO}_{2} \mathrm{R}$ $0{ }^{\circ} \mathrm{C}$<smiles>[X]CCC12CC3CC4COC(C1)(OO2)C(C4)C3</smiles>

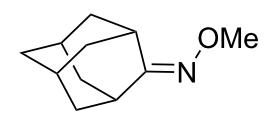

$\mathrm{R}=\mathrm{Alk}, \mathrm{Ar}$

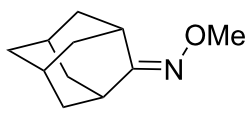<smiles>[R]C1([R])CCC(=O)CC1COCCOCc1ccccc1</smiles>
pentane, $\mathrm{CH}_{2} \mathrm{Cl}_{2}$, $0{ }^{\circ} \mathrm{C}$<smiles>[R]C1([R])CCC2(CC1)OOC1(OC3CC4CC(C3)CC1C4)O2</smiles>

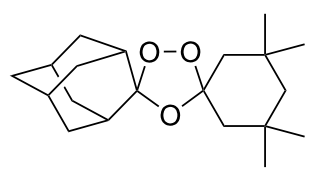


Table 13: Examples of ozonides (1,2,4-trioxolanes) synthesized by the Griesbaum method. (continued)
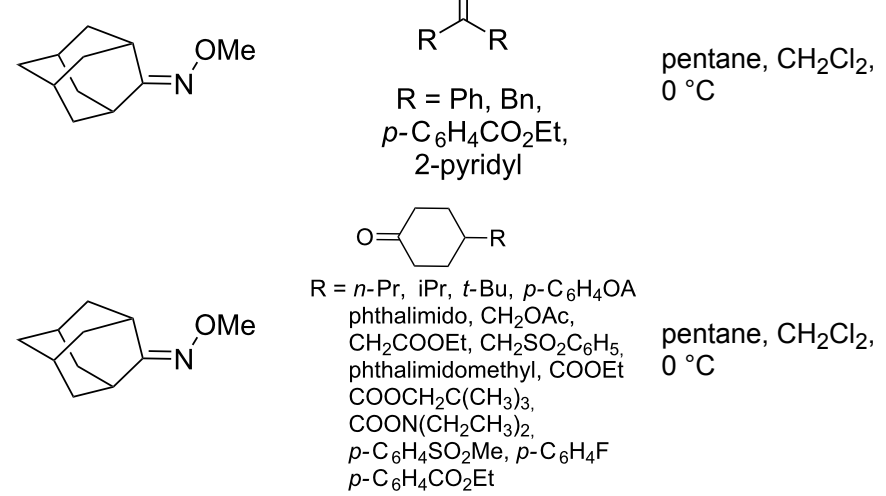

$\mathrm{R}=\mathrm{Ph}, \mathrm{Bn}$, p- $\mathrm{C}_{6} \mathrm{H}_{4} \mathrm{CO}_{2} \mathrm{Et}$,

pentane, $\mathrm{CH}_{2} \mathrm{Cl}_{2}$, $0{ }^{\circ} \mathrm{C}$

$\mathrm{R}=n-\mathrm{Pr}, \mathrm{PPr}, t-\mathrm{Bu}, p-\mathrm{C}_{6} \mathrm{H}_{4} \mathrm{OA}$ phthalimido, $\mathrm{CH}_{2} \mathrm{OAc}$,

$\mathrm{CH}_{2} \mathrm{COOEt} \mathrm{CH}_{2} \mathrm{SO}_{2} \mathrm{C}_{6} \mathrm{H}_{5}$ pentane, $\mathrm{CH}_{2} \mathrm{Cl}_{2}$ phthalimidomethyl, $\mathrm{COOEt} \quad 0^{\circ} \mathrm{C}$ $\mathrm{COOCH}_{2} \mathrm{C}\left(\mathrm{CH}_{3}\right)_{3}$,

$\operatorname{COON}\left(\mathrm{CH}_{2} \mathrm{CH}_{3}\right)_{2}$,

$p-\mathrm{C}_{6} \mathrm{H}_{4} \mathrm{SO}_{2} \mathrm{Me}, p-\mathrm{C}_{6} \mathrm{H}_{4} \mathrm{~F}$

$p-\mathrm{C}_{6} \mathrm{H}_{4} \mathrm{CO}_{2} \mathrm{Et}$<smiles>[R]C1([R])OOC2(O1)C1CC3CC(C1)CC2C3</smiles><smiles>CON=C1CC(C)(C)CC(C)(C)C1</smiles><smiles>CC1(C)COC2(CCC(=O)CC2)OC1</smiles>

pentane, $0^{\circ} \mathrm{C}$<smiles>CON=C1CC2CCC1CC2</smiles><smiles>CC1(C)COC2(CCC(=O)CC2)OC1</smiles>

pentane $0^{\circ} \mathrm{C}$<smiles>O=C1CCC(c2ccccc2)CC1</smiles>

pentane, $\mathrm{CH}_{2} \mathrm{Cl}_{2}$, $0{ }^{\circ} \mathrm{C}$<smiles>CC1(C)COCC2(C1)OOC1(CCC3(CC1)CC(C)(C)C(C)(C)CO3)O2</smiles>

hexane, $\mathrm{CH}_{2} \mathrm{Cl}_{2}$, $0{ }^{\circ} \mathrm{C}$<smiles>CC1(C)COC2(CCC3(CC2)OOC2(CC4CC5CC4CCC52)OO3)OC1</smiles><smiles>O=CCCCc1ccccc1</smiles><smiles>CON=C1CCC(C(C)(C)C)CC1</smiles><smiles>CON=C1CCC(c2ccccc2)CC1</smiles><smiles>O=C(c1ccc(F)cc1)c1ccc(F)cc1</smiles>

pentane, $\mathrm{CH}_{2} \mathrm{Cl}_{2}$,
$0{ }^{\circ} \mathrm{C}$

pentane, $\mathrm{CH}_{2} \mathrm{Cl}_{2}$,
$0{ }^{\circ} \mathrm{C}$<smiles>c1ccc(C2CCC3(CC2)OOC2(CC4CC5CCC4CC52)OO3)cc1</smiles><smiles>CC(C)(C)C1CCC2(CC1)OOC1(CCC(c3ccccc3)CC1)OO2</smiles><smiles>Fc1ccc(C2(c3ccc(F)cc3)OOC3(CCC(c4ccccc4)CC3)O2)cc1</smiles><smiles>CON=C1C2CC3CC(C2)CC1C3</smiles><smiles>CC(=O)OC1(OCCF)CCC(=O)CC1</smiles>
pentane, $\mathrm{CH}_{2} \mathrm{Cl}_{2}$, $0^{\circ} \mathrm{C}$

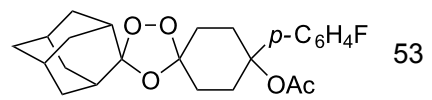<smiles>CON=C1CCC(C(C)(C)C)CC1</smiles><smiles>O=C1CCC(CNP)CC1</smiles>
pentane, $\mathrm{CH}_{2} \mathrm{Cl}_{2}$ $0{ }^{\circ} \mathrm{C}$<smiles>CC(C)(C)C1CCC2(CC1)OOC1(CCC(CN=[NH2+])CC1)OO2</smiles><smiles>CON=C1C2CC3CC1CC(OC(C)=O)(C3)C2</smiles><smiles>COC(=O)CC1CCC(=O)CC1</smiles>

cyclohexane $\mathrm{CH}_{2} \mathrm{Cl}_{2}, 0^{\circ} \mathrm{C}$<smiles>CCCCCCOC(=O)OC1C2CC3CC1CC(C2)C3=NOC</smiles><smiles>COC(=O)CC1CCC(=O)CC1</smiles>

cyclohexane $\mathrm{CH}_{2} \mathrm{Cl}_{2}, 0^{\circ} \mathrm{C}$

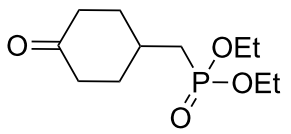

cyclohexane $\mathrm{CH}_{2} \mathrm{Cl}_{2}, 0^{\circ} \mathrm{C}$
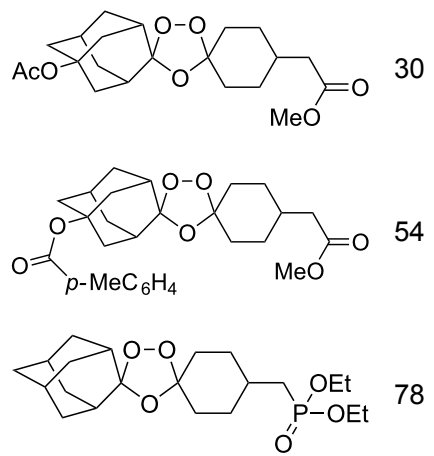

[91-93,96]

$[97,297]$

[258]

aYield was not determined 
The Griesbaum method is widely applicable and allows the selective synthesis of symmetrical and unsymmetrical 1,2,4trioxolanes, which are not accessible by direct ozonolysis of alkenes or the cross-ozonolysis of alkenes or enol ethers in the presence of carbonyl compounds. In addition, this method does not need tetrasubstituted alkenes or enol ethers as starting materials, which are difficult to prepare. Taking into account a wide range of commercially available ketones, it can be concluded that this is the most universal method for the synthesis of 1,2,4-trioxolanes in terms of selectivity and structural diversity of the final products.

\subsection{Other methods for the synthesis of 1,2,4-triox- olanes}

The reactions of aryloxiranes $\mathbf{1 7 7} \mathbf{a}, \mathbf{b}$ with oxygen in the presence of 9,10-dicyanoanthracene (DCA) and biphenyl (BiP) under irradiation produced 1,2,4-trioxolanes 178a and 178b (Scheme 46). It should be noted that the oxirane moiety is oxidized rather than the double bond in these reactions [299].

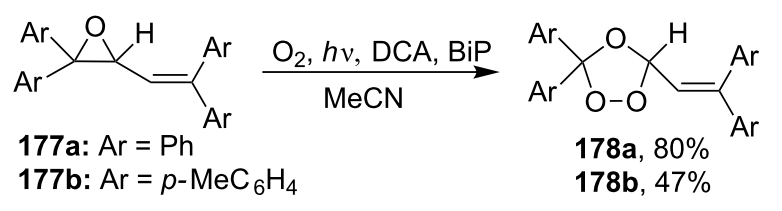

Scheme 46: Reactions of aryloxiranes $177 a, b$ with oxygen.

This unusual result was obtained upon treatment of the hydroxydioxepane, 3-methoxy-3-methyloctahydro-3 $\mathrm{H}$ benzo[c][1,2]dioxepin-9a-ol (179) with TMSOTf/Et ${ }_{3} \mathrm{SiH}$. Thus, the peroxide moiety was not reduced with $\mathrm{Et}_{3} \mathrm{SiH}$, and the reaction produced the bicyclic peroxide, 1-methyl-10,11,12-trioxatricyclo[7.2.1.0 4,9$]$ dodecane (180) containing the 1,2,4-trioxolane moiety, as the major product (Scheme 47) [270].

The same bicyclic peroxide $\mathbf{1 8 0}$ was synthesized in good yield by the reaction of 2-(2-(2-methyl-1,3-dioxolan-2-yl)ethyl)cyclohexanone (181) with hydrogen peroxide in the presence of phosphomolybdic acid (PMA) (Scheme 48) [300].

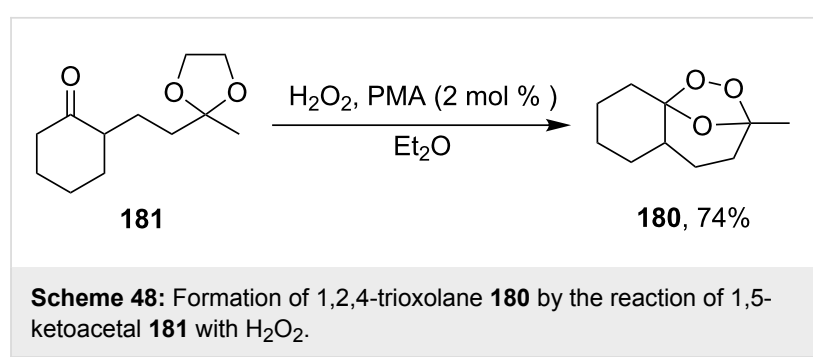

\subsection{Structural modifications, in which 1,2,4-triox- olane ring remains intact}

Scheme 49 shows possible modifications of substituents at the ozonide ring by the reduction of the ester group in cis-adamantane-2-spiro-3' -8' - ethoxycarbonyl-1',2',4' -trioxaspiro[4.5]decane 182 to form the alcohol cis-adamantane-2spiro-3'-8'-hydroxymethyl-1',2',4'-trioxaspiro[4.5]decane $\mathbf{1 8 3}$. The latter was mesylated to 184 (cis-adamantane-2-spiro-3'-8'methanesulfonylmethyl-1',2',4'-trioxa-spiro[4.5]decane), and used in the reaction with sodium 1-methyl- $1 H$-tetrazole-5-thiolate $\mathbf{1 8 5}$ for the synthesis of cis-adamantane-2-spiro-3'-8'-[[(1'methyl-1'H-tetrazol-5' -yl)thio] methyl]-1', 2', 4' trioxaspiro[4.5]decane $\mathbf{1 8 6}$ through nucleophilic substitution of the mesyl group by the thio group of tetrazole 185 (Scheme 49) [297].

Ozonide 188 was synthesized by Mitsunobu reaction of alcohol 183 with pyridin-4-ol (187) (Scheme 50) [93]. It should be emphasized that this method can be applied in spite of the use of triphenylphosphine, which is a strong reducing agent for peroxides.

The alkylation of the sodium salt of alcohol 183 with 2-chloropyrimidine in dimethylformamide gave ozonide 189 (Scheme 51). In this reaction, neither sodium hydride nor sodium salt 183 cleave the ozonide ring to a substantial degree. The resulting 1,2,4-trioxolanes $\mathbf{1 8 8}$ and $\mathbf{1 8 9}$ exhibit high in vitro antimalarial activity comparable with that of artemisinin and in vivo even higher activity than that of artemisinin [93].

Aminoquinoline-containing 1,2,4-trioxalane 191 was synthesized by reductive amination of adamantane-2-spiro-3'-8' -oxo-

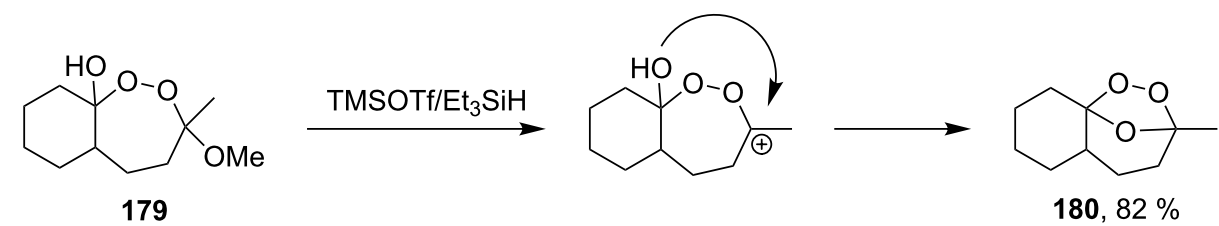

TMSOTf $=$ trimethylsilyl trifluoromethanesulfonate 


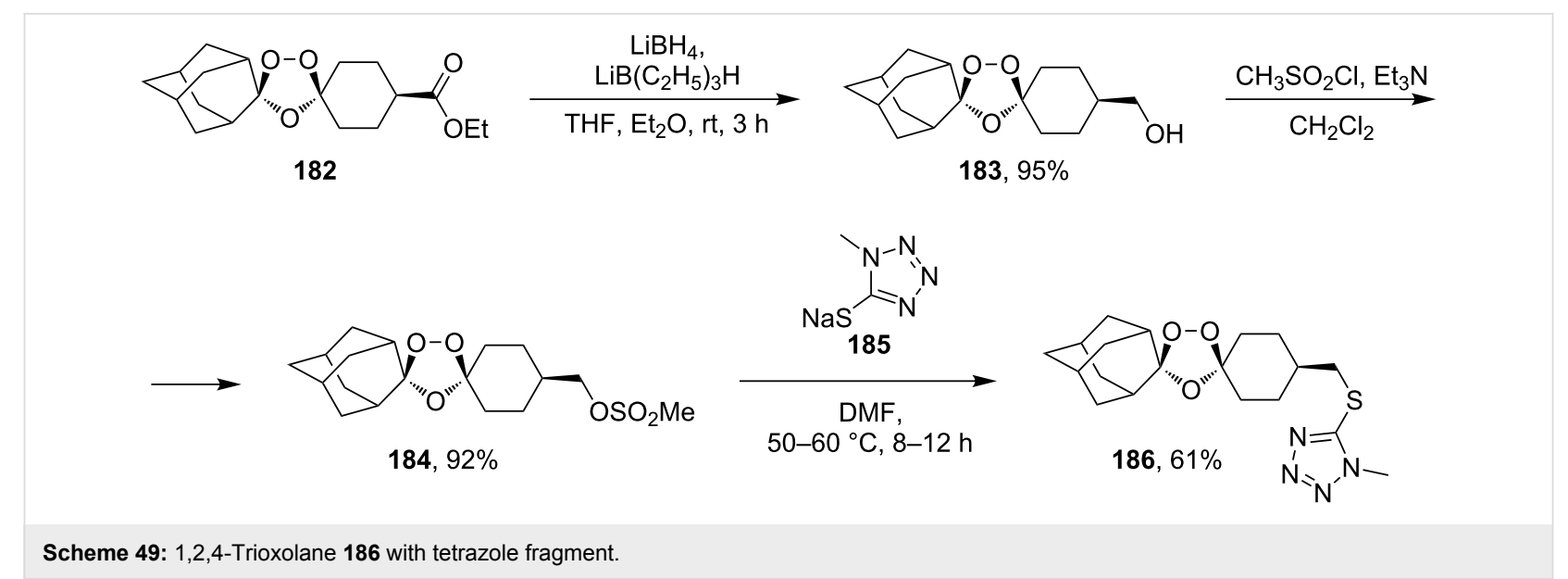

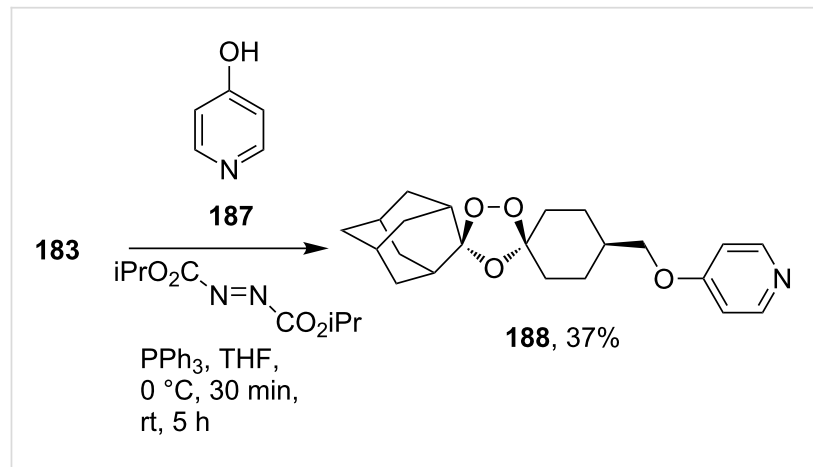

Scheme 50: 1,2,4-Trioxolane 188 with a pyridine fragment.

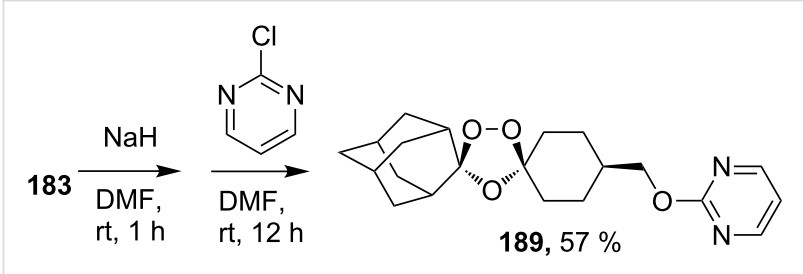

Scheme 51: 1,2,4-Trioxolane 189 with pyrimidine fragment.

1',2',4'-trioxaspiro[4.5]-decane 190 (Scheme 52). Ozonide 191 is an example of a combination of two known antiparasitic pharmacophores, viz. a peroxide and an aminoquinoline moiety [296].
Arterolane is a fully synthetic 1,2,4-trioxalane, also known as OZ277. It has high antimalarial activity and is currently in the final stage of clinical trials. As drug, this compound is used in combination with piperaquine. The synthesis of arterolane is based on the Griesbaum coozonolysis of a mixture of adamantan-2-one $O$-methyloxime (192) and 4-carbomethoxycyclohexanone 193 to form cis-adamantane-2-spiro-3'-8'methoxycarbonylmethyl-1',2',4'-trioxaspiro[4.5]decane 194. The latter is hydrolyzed to cis-adamantane-2-spiro-3'-8'carboxymethyl-1',2',4'-trioxaspiro[4.5]decane 195, followed by mild amidation with the formation of the intermediate ozonide 196 that on treatment with 2-methylpropane-1,2-diamine finally gives the target compound (Scheme 53). The in vitro and in vivo studies showed that arterolane is more active against causative agents of malaria than artemisinin, chloroquine, and mefloquine $[77,78,81]$.

\section{Synthesis of 1,2-dioxanes}

Modern approaches to the synthesis of 1,2-dioxanes are based on reactions with singlet oxygen, the oxidative coupling of carbonyl compounds and alkenes in the presence of manganese and cerium salts, the co-oxidation of alkenes and thiols with oxygen, the Isayama-Mukaiyama peroxidation, the Kobayashi cyclization of hydroperoxides, the reaction of 1,4-diketones with hydrogen peroxide, the intramolecular nucleophilic substitution by the hydroperoxide group, the cyclization with partici-

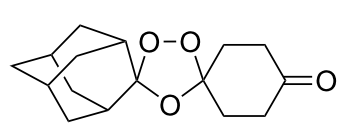

190

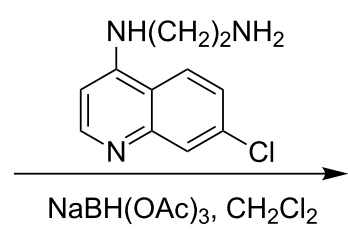

$\mathrm{NaBH}(\mathrm{OAc})_{3}, \mathrm{CH}_{2} \mathrm{Cl}_{2}$

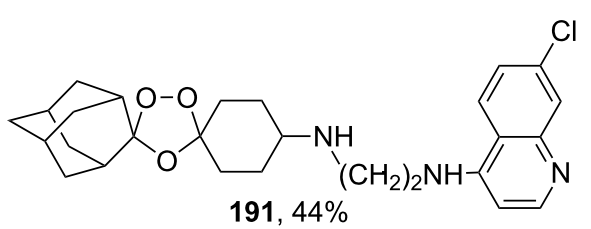

Scheme 52: Synthesis of aminoquinoline-containing 1,2,4-trioxalane 191. 


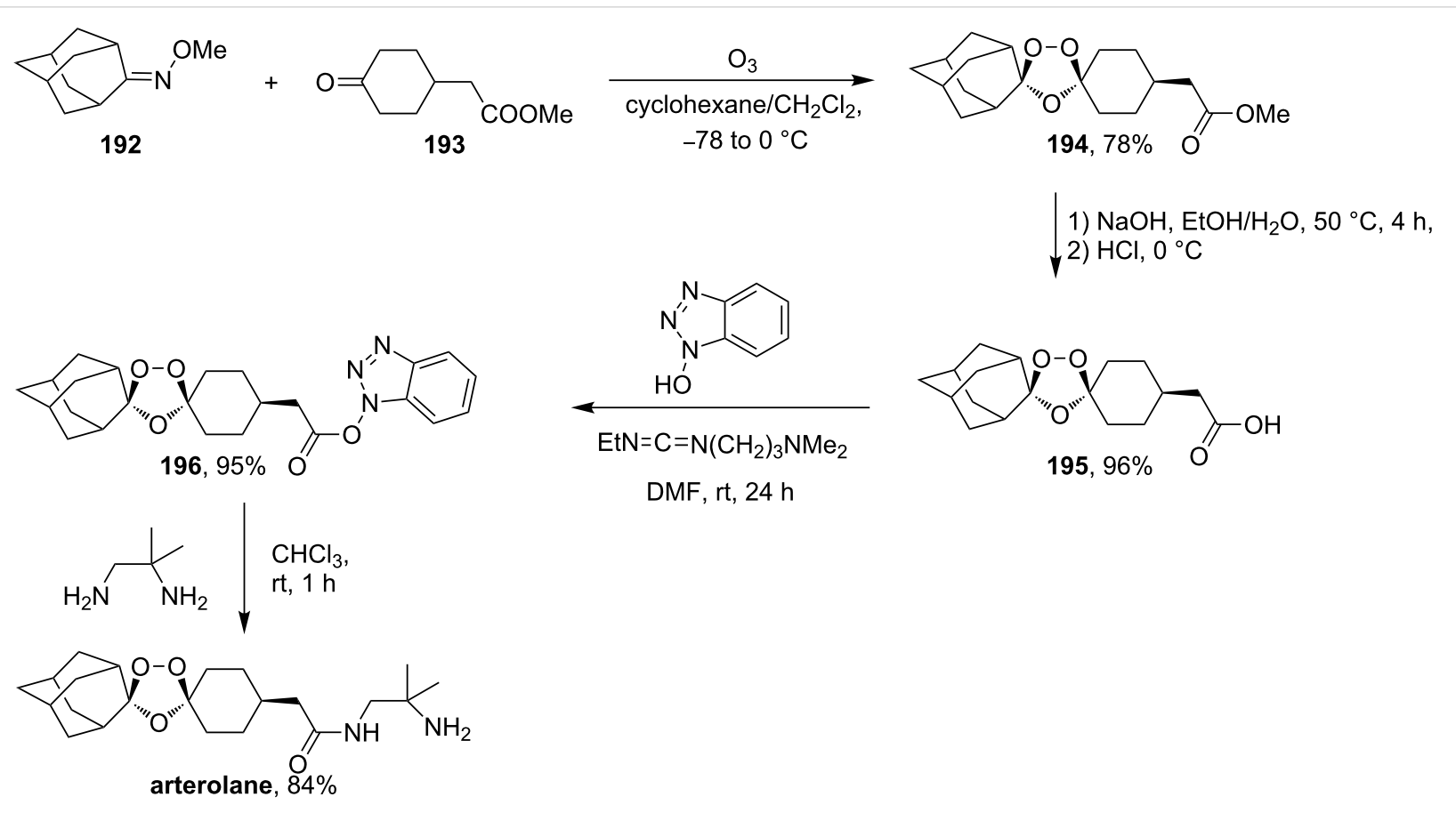

Scheme 53: Synthesis of arterolane.

pation of halogenonium ion donors, acid-mediated rearrangements of peroxides, the palladium-catalyzed cyclization of compounds with $\mathrm{C}=\mathrm{C}$ and $-\mathrm{O}-\mathrm{O}-$ groups, and reactions with the participation of peroxycarbenium ions.

\subsection{Methods for the synthesis of 1,2-dioxanes using singlet oxygen}

The oxidation of diarylheptadienes 197a-c with singlet oxygen in acetonitrile afforded bicyclic peroxides 198a-c in $33-58 \%$ yields. 2,4,6-Triphenylpyrylium tetrafluoroborate was used as the sensitizer for singlet oxygen generation (Scheme 54) [301]

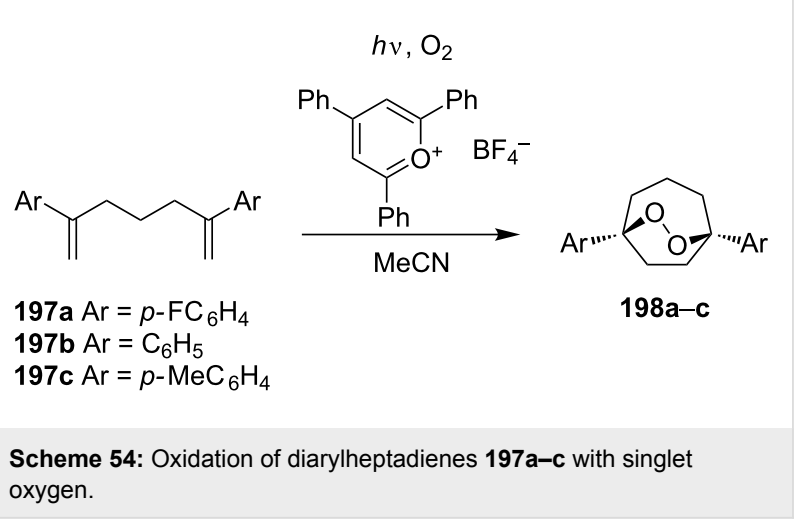

It was found that tris(bipyrazyl)ruthenium(II) $\left[\left(\mathrm{Ru}(\mathrm{bpz})_{3}\left(\mathrm{PF}_{6}\right)_{2}\right]\right.$ is an excellent photocatalyst for the synthesis of 1,2-dioxanes by aerobic photooxygenation of $\alpha, \omega$-dienes [302].
The addition of singlet oxygen to substrate 199 occurs in the last step of the synthesis of natural hexacyclinol peroxide $\mathbf{2 0 0}$ (Scheme 55) [303].

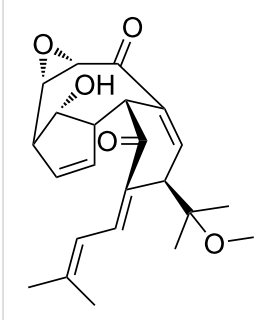

199

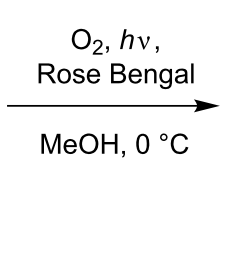

Scheme 55: Synthesis of hexacyclinol peroxide 200

The reactions of 6-methylhept-5-en-2-one (201) and 5 -methylhex-4-enenitrile (203) with singlet oxygen produced 1,2-dioxanes, 3-methyl-6-(prop-1-en-2-yl)-1,2-dioxan-3-ol (202) and 6-(prop-1-en-2-yl)-1,2-dioxane-3-imine (204), containing the hydroxy and imine groups, respectively (Scheme 56) [304].

\subsection{Oxidative coupling of carbonyl compounds and} alkenes in the presence of manganese or cerium

\section{salts}

The synthesis of 1,2-dioxanes $\mathbf{2 0 7}$ is based on the addition of alkene $\mathbf{2 0 5}$ and oxygen to carbonyl compound 206 via the inter- 


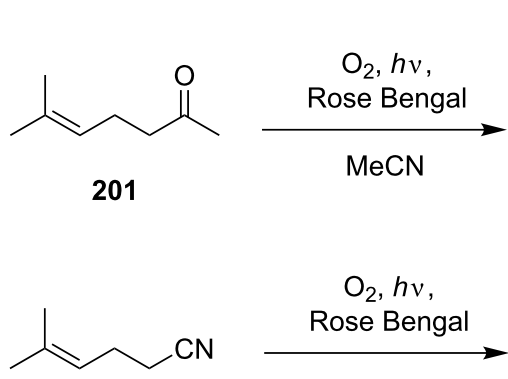

203<smiles>C=C(C)C1CCC(C)(O)OO1</smiles>

202, 53\%<smiles>C=C(C)C1CCC(=N)OO1</smiles>

204, $57 \%$
Scheme 56: Oxidation of enone 201 and enenitrile 203 with singlet oxygen. mediate formation of carbon-centered peroxide radicals. The reaction occurs in the presence of catalytic amounts of manganese or cerium salts, which are involved in a redox cycle. It is assumed that the oxidation of $\beta$-dicarbonyl compounds proceeds through a formation of an enol-containing complex with a metal ion (Scheme 57, Table 14).

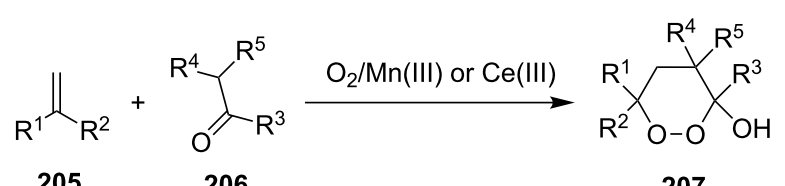

205

206

207

Scheme 57: Synthesis of 1,2-dioxanes 207 by oxidative coupling of carbonyl compounds 206 and alkenes 205.

Table 14: Examples of 1,2-dioxanes 207 synthesized by oxidative coupling of carbonyl compounds 206 and alkenes 205.

$\mathrm{Ph} \curvearrowright$<smiles>O=C1CCCCC1</smiles>

$\mathrm{Mn}(\mathrm{OAc})_{2}, \mathrm{O}_{2}$, $\mathrm{AcOH}, 80^{\circ} \mathrm{C}$, $10 \mathrm{~h}$<smiles>OC12CCCCC1CC(c1ccccc1)OO2</smiles>

67<smiles>[R]C([R])=C</smiles>

$\mathrm{R}^{1}=\mathrm{Ph}, 4-\mathrm{ClC}_{6} \mathrm{H}_{4}$, 4- $\mathrm{MeC}_{6} \mathrm{H}_{4}$, Et $\mathrm{R}^{2}=\mathrm{Ph}, 4-\mathrm{ClC}_{6} \mathrm{H}_{4}$, 4- $\mathrm{MeC}_{6} \mathrm{H}_{4}$, Et, $\mathrm{Me}, \mathrm{H}$<smiles>[R]C(=C)c1ccccc1</smiles>

$\mathrm{R}=\mathrm{H}, \mathrm{Me}$<smiles>[R]C(=C)Pc1ccccc1</smiles>

$\mathrm{R}=\mathrm{H}, \mathrm{Me}$

$\mathrm{Ph} \curvearrowright$

$\mathrm{Ph} \curvearrowright$<smiles>[R4]OC(=O)C1CN(C([R])=O)CCC1=O</smiles>

$\mathrm{R}^{3}=\mathrm{Ph}, \mathrm{Me}, \mathrm{Et}, \mathrm{Et}_{2} \mathrm{~N}$

$\mathrm{Mn}(\mathrm{OAc})_{3}$, air $\mathrm{AcOH}, 23^{\circ} \mathrm{C}$, 0.5-24 h

$$
\mathrm{R}^{4}=\mathrm{Et}, \mathrm{Bu}
$$

$\mathrm{CeCl}_{3} \times 7 \mathrm{H}_{2} \mathrm{O}$, air, $\mathrm{PrOH}$, rt, $16 \mathrm{~h}$<smiles>[R]CC1(C)C([R2])([R2])OOC2(O)CCN(C([R])=O)CC21C</smiles>
20-84 [306]<smiles>[Y]C(=O)C1CCCCC1=O</smiles>
$\mathrm{Y}=\mathrm{OEt}$, OMe $n=0,1,2$<smiles>[X]C1=C(C(C)=O)CC[Y]1=O</smiles>
$\mathrm{X}=\mathrm{O}, \mathrm{NCH}_{2} \mathrm{Ph}$ air, $\mathrm{iPrOH}$, rt, $16 \mathrm{~h}$<smiles>[Y]C1CCC2(O)OOC([R])(c3ccccc3)CC2(C=O)C1</smiles>
42-87 [307]<smiles>[X]C1=CCC2(CC([R])(c3ccccc3)OOC2(C)O)C1=O</smiles>

$\mathrm{CeCl}_{3} \times 7 \mathrm{H}_{2} \mathrm{O}$, air, $\mathrm{iPrOH}$, rt, 14-16 h

$\mathrm{CeCl}_{3} \times 7 \mathrm{H}_{2} \mathrm{O}$ air, iPrOH, rt, 14-16 h<smiles>CCOC(=O)C(CC)C(C)=O</smiles>

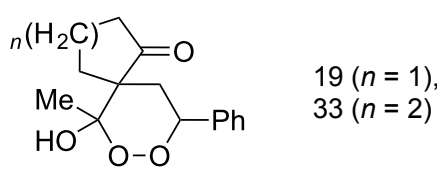

18<smiles>CCOCC1(CC)CC(c2ccccc2)OOC1(C)O</smiles>

$\mathrm{CeCl}_{3} \times 7 \mathrm{H}_{2} \mathrm{O}$, 
Table 14: Examples of 1,2-dioxanes 207 synthesized by oxidative coupling of carbonyl compounds 206 and alkenes 205. (continued)

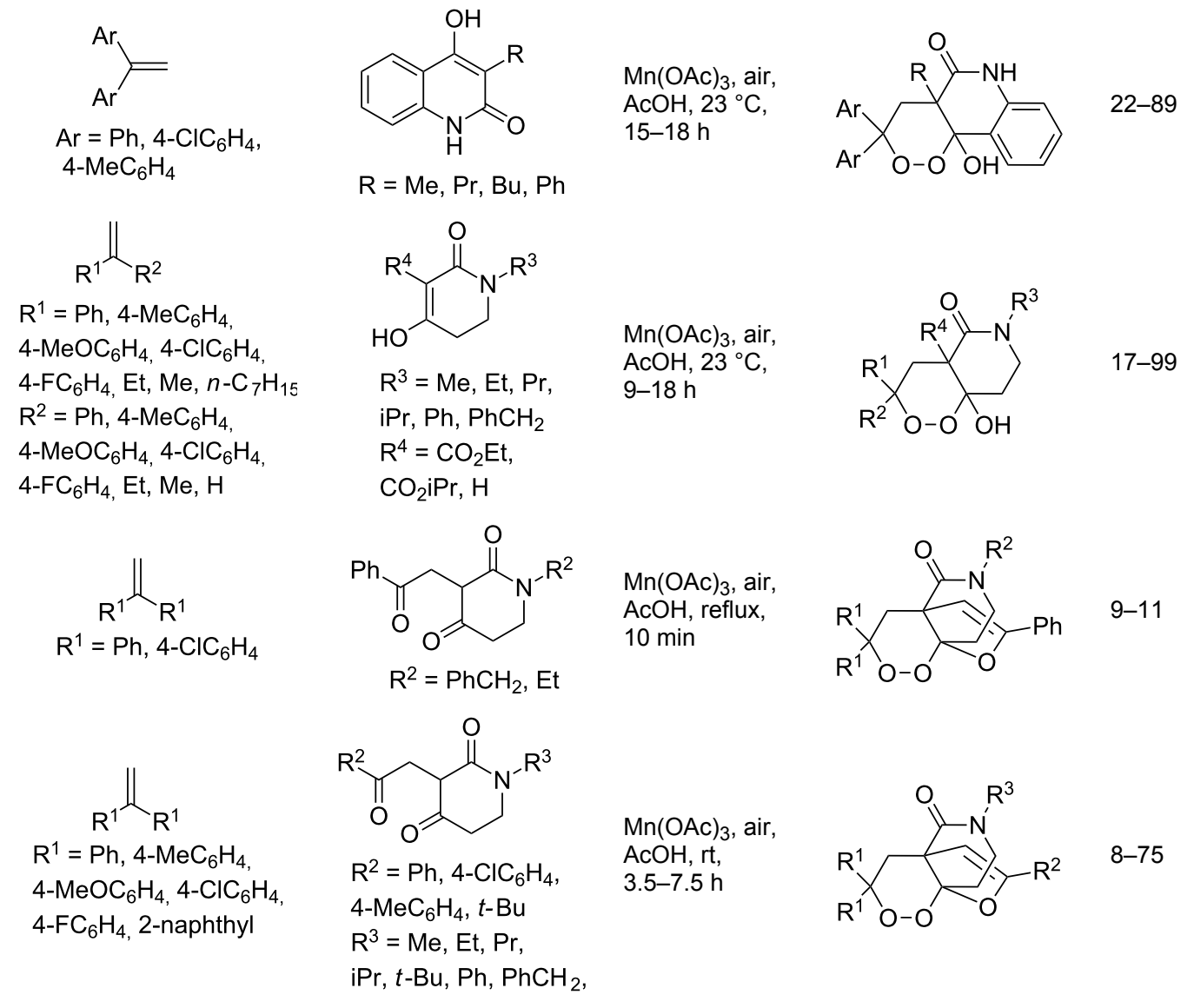

[309]

$\mathrm{AcOH}, 23^{\circ} \mathrm{C}$, $15-18 \mathrm{~h}$

$=\mathrm{Me}, \mathrm{Pr}, \mathrm{Bu}, \mathrm{Ph}$

$\mathrm{AcOH}, 23^{\circ} \mathrm{C}$

$\mathrm{R}^{3}=\mathrm{Me}, \mathrm{Et}, \mathrm{Pr}, \quad 9-18 \mathrm{~h}$

$\mathrm{Pr}, \mathrm{Ph}, \mathrm{PhCH}_{2}$

$\mathrm{R}^{4}=\mathrm{CO}_{2} \mathrm{Et}$

$\mathrm{AcOH}$, reflux,

$10 \mathrm{~min}$

$\mathrm{AcOH}, \mathrm{rt}$

$5-7.5 \mathrm{~h}$

$\mathrm{R}^{3}=\mathrm{Me}, \mathrm{Et}, \mathrm{Pr}$

iPr, $t$-Bu, $\mathrm{Ph}, \mathrm{PhCH}_{2}$
[311]
3.3. Oxidation of 1,5-dienes in the presence of thiols The co-oxidation of 1,4-dienes and thiols (thiol-olefin co-oxygenation, TOCO reaction) was described for the first time by Beckwith and Wagner as a method for the synthesis of sulfur-containing 1,2-dioxolanes [313,314]. More recently, it has been shown that under similar conditions, the oxidation of 1,5-dienes $\mathbf{2 0 8}$ affords the corresponding sulfur-containing 1,2dioxanes 209. The reaction proceeds under oxygen atmosphere in the presence of azobisisobutyronitrile (AIBN) or ditert-butyl peroxalate (DBPO) as radical initiators. The resulting unstable hydroperoxides are reduced with triphenylphosphine to hydroxy derivatives 209 (Scheme 58, Table 15).

The oxidation of acetophenones $\mathbf{2 1 0}$ produces bicyclic 1,2-dioxanes 212 (Scheme 59). It is hypothesized that the reaction gives hydroperoxide $\mathbf{2 1 1}$ as the intermediate, that undergoes rapid cyclization to form the target 1,2-dioxane $\mathbf{2 1 2}$ [317].<smiles>[R]C(=C)C1CC=C(C)C([R])C1</smiles>

208

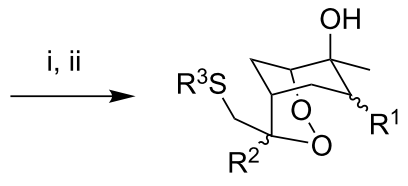

209 


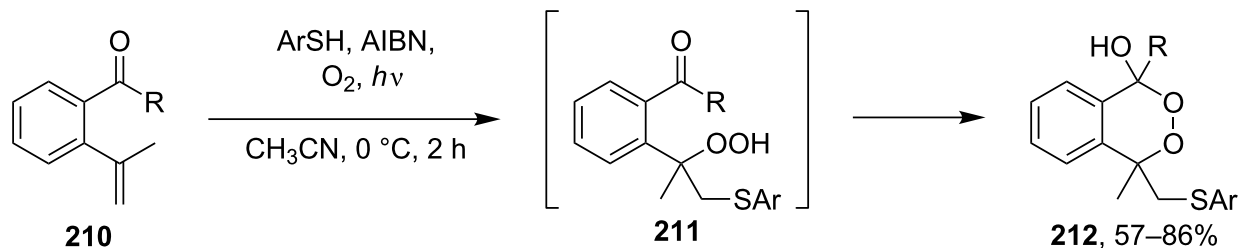

$\mathrm{R}=\mathrm{Me}, t-\mathrm{Bu}$

$\mathrm{Ar}=\mathrm{Ph}, 3,5-\mathrm{Me}_{2} \mathrm{C}_{6} \mathrm{H}_{3}, 4-t-\mathrm{BuC}_{6} \mathrm{H}_{4}, 4-\mathrm{BrC}_{6} \mathrm{H}_{4}, 4-\mathrm{MeOC}_{6} \mathrm{H}_{4}$

Scheme 59: Synthesis of bicyclic 1,2-dioxanes $\mathbf{2 1 2}$ with aryl substituents.

Table 15: Examples of 1,2-dioxanes synthesized by co-oxidation of 1,5-dienes and thiols.

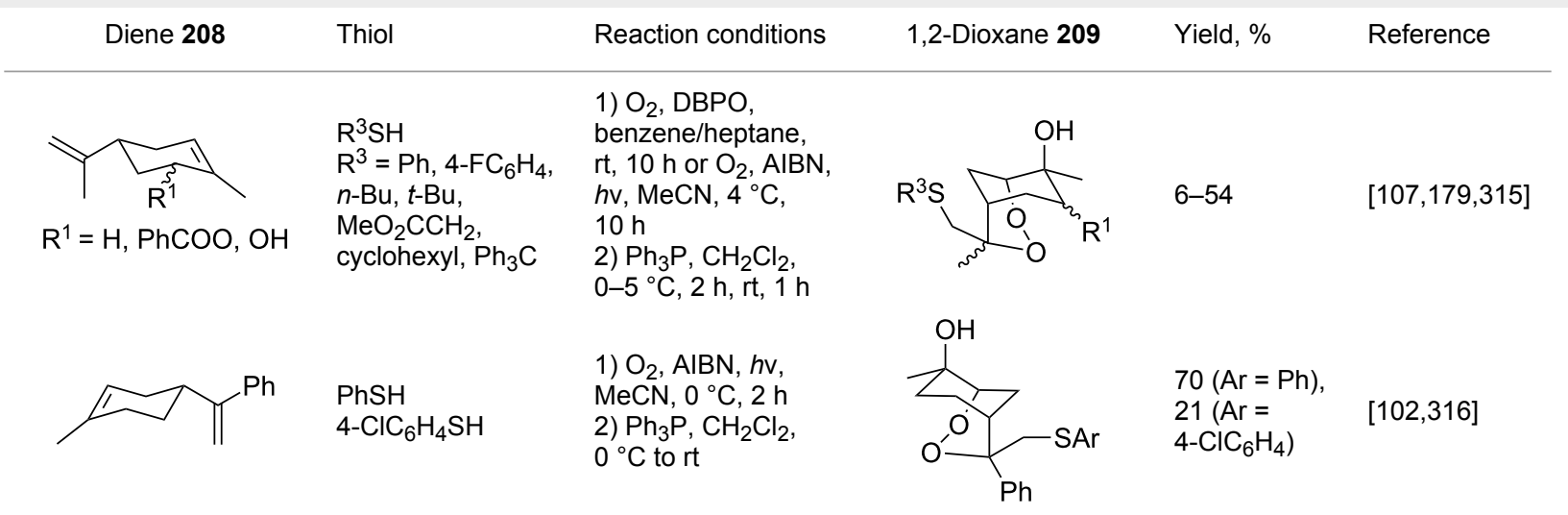

\subsection{Synthesis of 1,2-dioxanes by the Isayama-Mukaiyama method}

The Isayama-Mukaiyama peroxysilylation of 1,5-dienes 213 followed by desilylation under acidic conditions gives hydroperoxide-containing 1,2-dioxanes 214 (Scheme 60, Table 16).

The oxidation of (Z)-ethyl 2-(3-(prop-1-en-2-yl)cyclohexylidene)acetate (215) gives ethyl 2-(4,4-dimethyl-2,3-dioxabicyclo[3.3.1]nonan-1-yl)-2-hydroxyacetate (218) in 29\% yield. The oxidative reaction proceeds presumably with formation of an O-centered radical 216, then a C-centered radical 217 and the latter adds oxygen and is reduced to the hydroxy derivative of 1,2-dioxane 218 (Scheme 61) [318].
An alternative synthesis of a 1,2-dioxane by the Isayama-Mukaiyama method includes the following sequence of reactions: peroxysilylation, desilylation, and recyclization<smiles>[R]C(=C)C([R])([R])C/C=C(/[R])C</smiles>

Scheme 60: Isayama-Mukaiyama peroxysilylation of 1,5-dienes 213 followed by desilylation under acidic conditions.<smiles>C=C(C)C1CCC/C(=C/C(=O)OCC)C1</smiles>

215<smiles>CCOC(=O)C=C1CCCC(C(C)(C)O[O])C1</smiles><smiles>CCOC(=O)CC12CCCC(C1)C(C)(C)OO2</smiles>

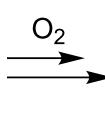

217<smiles>CCOC(=O)C(O)C12CCCC(C1)C(C)(C)OO2</smiles>

218

Scheme 61: Synthesis of bicycle 218 with an 1,2-dioxane ring. 
Table 16: Synthesis of 1,2-dioxanes by the Isayama-Mukaiyama method.

1,5-Diene 213<smiles>[R]C([R])(CC=C(C)C)C(=C)c1ccccc1</smiles>

$R^{1}, R^{2}=H, M e, P h$<smiles>C=C(C)C1CC=C(C)CC1</smiles>

Reaction conditions ${ }^{a}$

1) $\mathrm{Co}(\operatorname{modp})_{2}, \mathrm{O}_{2}, \mathrm{Et}_{3} \mathrm{SiH}$, $\mathrm{ClCH}_{2} \mathrm{CH}_{2} \mathrm{Cl}$,

2-6 h

2) $\mathrm{HCl} / \mathrm{MeOH}$

1) $\mathrm{Co}(\operatorname{modp})_{2}, \mathrm{O}_{2}, \mathrm{Et}_{3} \mathrm{SiH}$, $\mathrm{ClCH}_{2} \mathrm{CH}_{2} \mathrm{Cl}$

$1 \mathrm{~h}$

2) $\mathrm{HCl} / \mathrm{MeOH}$
1,2-Dioxane 214

Yield, \% Reference<smiles>[R]C1([R])CC(C(C)(C)O)OOC1(C)P</smiles>

$13-64$

[249]<smiles>CC1(O)CCC2CC1OOC2(C)C</smiles>

accompanied by a ring opening of oxirane or oxetane (Scheme 62 and Scheme 63).

Cobalt(II) acetylacetonate (acac) or bis-2,2,6,6-tetramethylheptane-3,5-dienoate (thd) were used as the catalyst for the peroxidation of 219. The cyclization of the intermediate peroxide $\mathbf{2 2 0}$ was performed with Amberlyst-15 ion-exchange resin. This approach was used in the multistep synthesis of the natural endoperoxide 9,10-dihydroplakortin, which exhibits antimalarial and anticancer activities as do its structural analogues [320,321].
2-(3,6,6-Trimethyl-1,2-dioxan-3-yl)ethanol (224) was synthesized in a similar way starting with the peroxidation of 2-methyl-2-(3-methylbut-3-enyl)oxetane (222), followed by oxetane-ring opening in triethyl(2-methyl-4-(2-methyloxetan-2yl)butan-2-ylperoxy)silane (223) (Scheme 63) [250].

Dioxanes can also be synthesized by inramolecular cyclizations with the attack on a keto group. The peroxysilylation of the unsaturated ketone 1,5-dicyclohexenylpentan-3-one (225), with the $\mathrm{Co}(\mathrm{thd})_{2} / \mathrm{Et}_{3} \mathrm{SiH} / \mathrm{O}_{2}$ system produced 1,5-bis(1-(triethylsi-

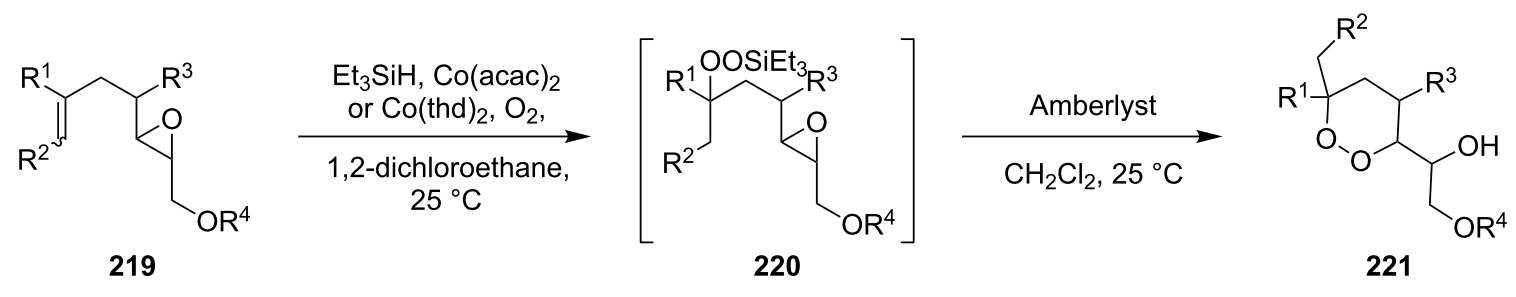

221a $R^{1}=M e, R^{2}=H, R^{3}=E t, R^{4}=A c, 75 \%$

221b $R^{1}=M e, R^{2}=H, R^{3}=E t, R^{4}=C_{3} \mathrm{SO}_{2}, 45 \%$

221c, d R $R^{1}=M e, R^{2}=M e, E t, R^{3}=H, R^{4}=A c, 58-65 \%$

221e,f, $\mathrm{g} \mathrm{R}^{1}=\mathrm{Me}, \mathrm{R}^{2}=n$-BuCHEt, EtCHEt, Et, $\mathrm{R}^{3}=\mathrm{Et}, \mathrm{R}^{4}=\mathrm{Ac}, 36-45 \%$

Scheme 62: Intramolecular cyclization with an oxirane-ring opening.<smiles>C=C(C)CCC1(C)CCO1</smiles>

222

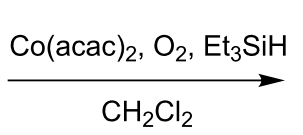

$\mathrm{CH}_{2} \mathrm{Cl}_{2}$

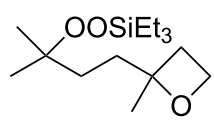

$223,82 \%$
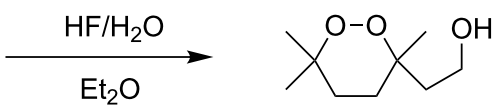

$224,73 \%$ 
<smiles>O=C(CCC1=CCCCC1)CCC1CCCCC1</smiles>

225

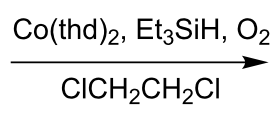

$\mathrm{ClCH}_{2} \mathrm{CH}_{2} \mathrm{Cl}$<smiles>CCOC1(CCC(=O)CCC2(OCC)CCCCC2)CCCCC1</smiles>

226, $72 \%$
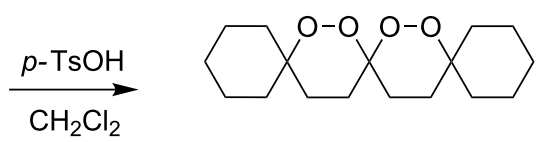

$227,88 \%$

Scheme 64: Intramolecular cyclization with the attack on a keto group.

lylperoxy)cyclohexyl)pentan-3-one (226), which underwent cyclization in the presence of $p$-toluenesulfonic acid to give the spiro-fused 7,8,10,11-tetraoxatrispiro[5.2.2.5.2.2] henicosane 227 (Scheme 64) [252].

\subsection{Synthesis of 1,2-dioxanes by the Kobayashi method}

The synthesis is based on the peroxidation of the carbonyl group of unsaturated ketones $\mathbf{2 2 8}$ with the urea-hydrogen peroxide complex followed by a Michael cyclization of the hydroperoxy acetals $\mathbf{2 2 9}$ under basic conditions. This method is suitable for the efficient synthesis of functionalized 1,2-dioxanes $\mathbf{2 3 0}$ in moderate to high yields (Scheme 65, Table 17). In early studies, scandium(III) triflate was used as the catalyst for the hydroperoxidation of ketones with the $\mathrm{H}_{2} \mathrm{O}_{2}-\mathrm{H}_{2} \mathrm{NCONH}_{2}$ complex. More recently, it was shown that in some cases, cheaper catalysts such as $p$-toluenesulfonic and 10-camphorsulfonic acid can be used for this purpose (Table 17).<smiles>[R]C(=O)CCC=C([R])[R]</smiles>

228

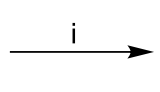<smiles>[R]C([R])=CCCC([R])(O)O</smiles>

229

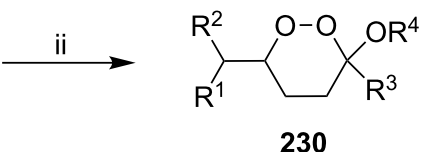

230

Scheme 65: Peroxidation of the carbonyl group in unsaturated ketones 228 followed by cyclization of hydroperoxy acetals 229.

Table 17: Examples of 1,2-dioxanes synthesized by the Kobayashi method<smiles>CCCCCCCC(=O)CCC=CC(=O)OC</smiles>

1) $\mathrm{H}_{2} \mathrm{O}_{2} \cdot \mathrm{H}_{2} \mathrm{NCONH}_{2}$, $\mathrm{Sc}(\mathrm{OTf})_{3}, \mathrm{MeOH}$ 2) $\mathrm{Et}_{2} \mathrm{NH}, \mathrm{CF}_{3} \mathrm{CH}_{2} \mathrm{OH}$, $0{ }^{\circ} \mathrm{C}, 2 \mathrm{~d}$

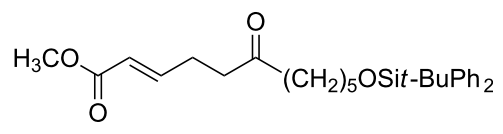

1) $\mathrm{H}_{2} \mathrm{O}_{2} \cdot \mathrm{H}_{2} \mathrm{NCONH}_{2}$, $\mathrm{Sc}(\mathrm{OTf})_{3}, \mathrm{MeOH}$

2) $\mathrm{Et}_{2} \mathrm{NH}, \mathrm{CF}_{3} \mathrm{CH}_{2} \mathrm{OH}$

3) $\mathrm{HF}$, pyridine, THF<smiles>[R]C(=O)C([R2])=CCCC(=O)[SH2]</smiles>

$\mathrm{R}^{1}=\mathrm{OMe}, \mathrm{O} t-\mathrm{Bu}, \mathrm{Me}, \mathrm{Ph}$

1) $\mathrm{H}_{2} \mathrm{O}_{2} \cdot \mathrm{H}_{2} \mathrm{NCONH}_{2}$, $\mathrm{Sc}(\mathrm{OTf})_{3}, \mathrm{MeOH}$ 2) $\mathrm{Et}_{2} \mathrm{NH}, \mathrm{CF}_{3} \mathrm{CH}_{2} \mathrm{OH}$ $\mathrm{R}^{2}=\mathrm{Me}, \mathrm{H}$<smiles>[R]C(=O)CCC=CC(=O)OC</smiles>

1) $\mathrm{H}_{2} \mathrm{O}_{2} \cdot \mathrm{H}_{2} \mathrm{NCONH}_{2}$, $\mathrm{Sc}(\mathrm{OTf})_{3}, \mathrm{MeOH}$

$\mathrm{R}=\mathrm{Ph}, \mathrm{PhCH}_{2}, \mathrm{CH}_{2}=\mathrm{CHCH}_{2} \mathrm{CH}_{2} \mathrm{CH}_{2}$, 2) $\mathrm{Et}_{2} \mathrm{NH}, \mathrm{CF}_{3} \mathrm{CH}_{2} \mathrm{OH}$

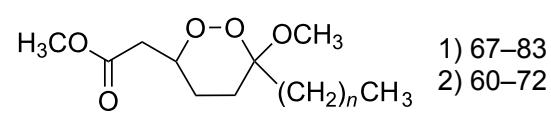

[322,323]

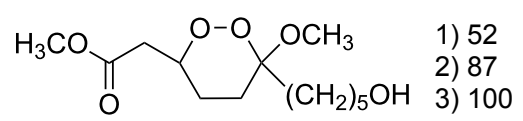<smiles>[R1]C(=O)C([R])C1CCC(C)(OC)OO1</smiles>

8-38 [104-106]<smiles>[R]C1(OC)CCC(CC(=O)OC)OO1</smiles>
28-58 
<smiles>[R]OC(=O)/C=C/CCC(=O)CCCO</smiles>

$\mathrm{R}=\mathrm{Et}, \mathrm{PhCH}_{2}$

Intermediate product $\mathbf{2 2 9}$ has the following structure:<smiles>[R]OC(=O)/C=C/CCC1(O)CCCO1</smiles><smiles>O=C(CCC=C[N+](=O)[O-])CCCO</smiles><smiles>CCOC(=O)C1CC(=O)c2ccccc2C1</smiles>

Intermediate product $\mathbf{2 2 9}$ has the following structure:<smiles>CCOC(=O)C=Cc1ccccc1C1(O)CCCO1</smiles><smiles>[R]C(CCOCC)C(=O)CC/C=C/C(=O)OCC</smiles><smiles>[R]NCCOCCCC</smiles><smiles>[R]C(C)C(=O)CC/C=C/C(=O)OCC</smiles>

$\mathrm{R}=\mathrm{H}, \mathrm{Me}, \mathrm{EtOOCCH}, \mathrm{AcOCH}_{2} \mathrm{CH}_{2}$

1) $\mathrm{H}_{2} \mathrm{O}_{2} \cdot \mathrm{H}_{2} \mathrm{NCONH}_{2}$, p-TsOH, $\mathrm{MeOH}, \mathrm{rt}$, $20 \mathrm{~h}$ 2) $\mathrm{Et}_{2} \mathrm{NH}, \mathrm{CF}_{3} \mathrm{CH}_{2} \mathrm{OH}$, rt, $24 \mathrm{~h}$<smiles>[R]OC(=O)CC1CCC2(CCCO2)OO1</smiles>
1) $54-82$ 2) 52 [325-327] $\mathrm{H}_{2} \mathrm{O}_{2}-\mathrm{H}_{2} \mathrm{NCONH}_{2}$, p- $\mathrm{TsOH}$, 1,2-dimethoxyethane, rt, $11 \mathrm{~h}$<smiles>O=[N+]([O-])CC1CCC2(CCCO2)OO1</smiles>
35

[325-327]

1) $\mathrm{H}_{2} \mathrm{O}_{2} \cdot \mathrm{H}_{2} \mathrm{NCONH}_{2}$, 10-camphorsulfonic acid 1,2-dimethoxyethane, rt, $18 \mathrm{~h}$

2) $\mathrm{Et}_{2} \mathrm{NH}, \mathrm{CF}_{3} \mathrm{CH}_{2} \mathrm{OH}, \mathrm{rt}$, $2 \mathrm{~h}$

1) $\mathrm{H}_{2} \mathrm{O}_{2} \cdot \mathrm{H}_{2} \mathrm{NCONH}_{2}$ $p$-TsOH, EtOH, rt, $10 \mathrm{~h}$

2) $\mathrm{Et}_{2} \mathrm{NH}, \mathrm{CF}_{3} \mathrm{CH}_{2} \mathrm{OH}, \mathrm{rt}$, $12 \mathrm{~h}$

1) $\mathrm{H}_{2} \mathrm{O}_{2} \cdot \mathrm{H}_{2} \mathrm{NCONH}_{2}$, p-TsOH, EtOH, rt, $12 \mathrm{~h}$

2) $\mathrm{Et}_{2} \mathrm{NH}, \mathrm{CF}_{3} \mathrm{CH}_{2} \mathrm{OH}, \mathrm{rt}$

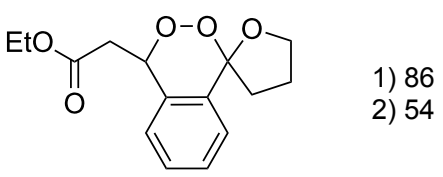

[325-327]<smiles>[R]C1CCOC12CCC(CC(=O)OCC)OO2</smiles>

1) $72-80$

2) $40-52$<smiles>[R]C1CCCOC12CCC(CC(=O)OCC)OO2</smiles>

1) $70-93$

2) $42-65$

[328]
It was found that cesium hydroxide can be used as a base for the cyclization to give $\mathbf{2 3 2}$ and 234. Compared to Scheme 65, the method is suitable for the cyclization of hydroperoxides $\mathbf{2 3 1}$ and 233, which are no ketone derivatives (Scheme 66) [264]. $\mathrm{Et}_{3} \mathrm{~N}$ in $\mathrm{MeOH}$ can also be used as catalyst for this type of cyclization [263].<smiles>[R]C(O)CC/C=C/C(=O)OC</smiles><smiles>COC(=O)/C=C/CCC(O)c1ccc(C)o1</smiles>

$\mathrm{CsOH}$ $\left(\mathrm{CF}_{3}\right)_{2} \mathrm{CHOH} / \mathrm{MeOH}(7: 3)$

$\mathrm{Et}_{2} \mathrm{NH}$ $\mathrm{CF}_{3} \mathrm{CH}_{2} \mathrm{OH} / \mathrm{MeOH}(7: 3)$<smiles>[R]C1CCC(CC(=O)OC)OO1</smiles>

232a $\mathrm{R}=\mathrm{H}, 35 \%$

232b $\mathrm{R}=\mathrm{Me}, 41 \%$<smiles>COC(=O)CC1CC(c2ccc(C)o2)OOC1(C)C</smiles> 
The synthesis of peroxyplakoric acid methyl ethers A and D 238a and $\mathbf{2 3 8 b}$, which are natural peroxides isolated from marine sponges exhibiting fungicidal and antitumor activities $[329,330]$ is an interesting example of the synthesis of complex structures. The polyunsaturated compound $(E)$-methyl 6-methyleneundec-2-en-10-ynoate (235) was subjected to ozonolysis to obtain methoxyhydroperoxide, $(E)$-methyl 6-hydroperoxy-6methoxyundec-2-en-10-ynoate (236), whose cyclization afforded methyl 2-(6-methoxy-6-(pent-4-inyl)-1,2-dioxan-3yl)acetate (237), in which the triple bond is easily modified by palladium-catalyzed cross-coupling reactions to form the target 1,2-dioxanes 238a,b (Scheme 67).

Initially, an attempt was made to synthesize diethyl 2,2'(1,2,7,8-tetraoxaspiro[5.5] undecane-3,9-diyl)diacetate (241) by cyclization of $(2 E, 9 E)$-diethyl 6,6-dihydroperoxyundeca-2,9dienedioate bis(hydroperoxide) (240) (the bishydroperoxidation product of $(2 E, 9 E)$-diethyl 6,6-dimethoxyundeca-2,9dienedioate (239)) with $\mathrm{Et}_{2} \mathrm{NH}$ in $\mathrm{CF}_{3} \mathrm{CH}_{2} \mathrm{OH}$. However, these attempts failed. Spiroperoxide $\mathbf{2 4 1}$ was prepared in satisfactory yield by reaction of $\mathbf{2 4 0}$ with the use of mercury (II) acetate
(Scheme 68) [331]. The intermediate mercury-containing peroxide produced by the cyclization of bis(hydroperoxide) 240 was reduced with $\mathrm{NaBH}_{4}$ in an alkaline medium [331].

\subsection{Synthesis of 1,2-dioxanes from 1,4-dicarbonyl compounds}

The reaction of 1,4-diketones 242 (cyclohexanone derivatives) with hydrogen peroxide in a neutral medium produced 3,6-dihydroxydioxanes $\mathbf{2 4 3}$ albeit without reported yields (Scheme 69). The resulting compounds exhibit a broad spectrum of antiparasitic activities against causative agents of malaria, trypanosomiasis, and leishmaniasis [208-212].

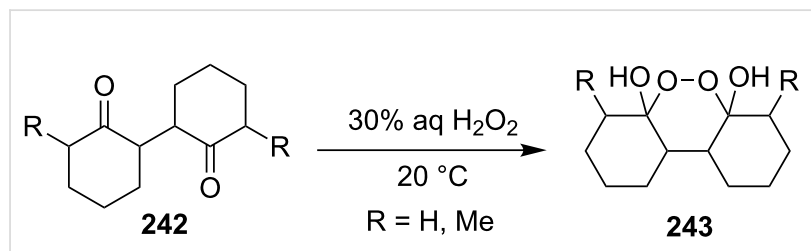

Scheme 69: Reaction of 1,4-diketones 242 with hydrogen peroxide.<smiles>C#CCCCC(=C)CC/C=C/C(=O)OC</smiles>

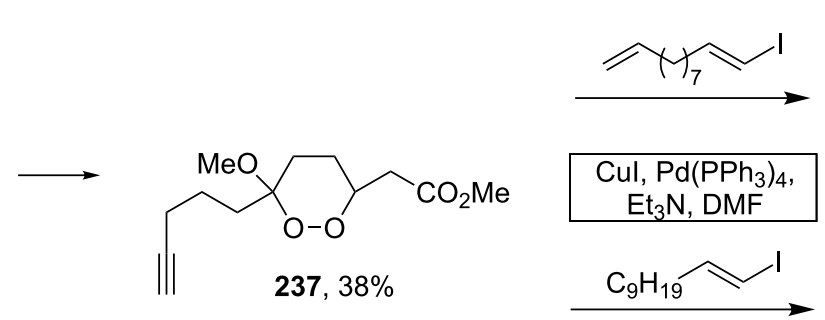

238a, $41 \%$<smiles></smiles>

238b, $46 \%$

Scheme 67: Preparation of peroxyplakoric acid methyl ethers A and D.

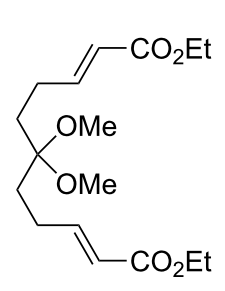

239

$\mathrm{O}_{2} \mathrm{Et}$

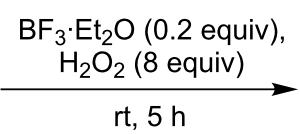

$\mathrm{rt}, 5 \mathrm{~h}$<smiles>CCOC/C=C/CCC(O)(O)CC/C=C/C(=O)OCC</smiles>

240, $45 \%$

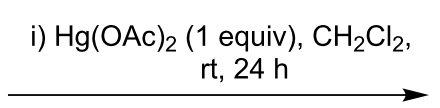

ii) $\mathrm{NaBH}_{4}$ (4 equiv), $\mathrm{NaOH}$, $0{ }^{\circ} \mathrm{C}, 1 \mathrm{~h}$<smiles>CCOC(=O)CC1CCC2(CCC(CC(=O)OCC)OO2)OO1</smiles>

$241,35 \%$ 


\subsection{Methods for the synthesis of 1,2-dioxanes from hydroperoxides}

Compounds containing a $\mathrm{C}=\mathrm{C}$ group and an oxygen-containing ring are convenient starting materials for the synthesis of cyclic peroxides [250-252,332]. For example, the ozonolysis of the double bond in the oxetane-containing compound, 2-methyl-2(3-methylbut-3-enyl)oxetane (244) afforded 2-(3-hydroperoxy3-methoxybutyl)-2-methyloxetane (245), which underwent recyclization in the presence of ytterbium triflate to give 2-(6methoxy-3,6-dimethyl-1,2-dioxan-3-yl)ethanol (246) along with the seven-membered compound 2-hydroperoxy-5-methoxy-2,5dimethyloxepane (247) (Scheme 70) [250].

Spirodioxane 227, whose synthesis by the Isayama-Mukaiyama method was described above (Scheme 64), could also be synthesized via the ozonolysis of alkene $\mathbf{2 4 8}$ in the presence of hydrogen peroxide followed by the cyclization of bis(hydroperoxide) $\mathbf{2 4 9}$ with potassium tert-butoxide (Scheme 71) [252].

An approach to the cyclization based on an intramolecular nucleophilic substitution was used also for the synthesis of diastereomers of dioxanes $\mathbf{2 5 2 a}$, b containing triple bonds. Hydroperoxides 251a,b that were synthesized by the ozonolysis of $\mathbf{2 5 0}$ were treated with potassium tert-butoxide. One of the diastereomers, 252a, was then modified first via the stereoselective hydrozirconation and iodination to 253a and then by the Negishi cross coupling to produce silylated product 254a, which was desilylated to obtain alcohol $255 a$ (Scheme 72). 1,2Dioxane 255a is structurally similar to natural peroxyplakoric acids having fungicidal and antimalarial activities [332].

\subsection{Use of halonium ions in the cyclization}

This approach to the synthesis of 1,2-dioxane rings is based on the intramolecular cyclization of hydroperoxides containing a $\mathrm{C}=\mathrm{C}$ group. In the first step, the addition of a halonium ion to the double bond results in the formation of a carbocation, which is subjected to the intramolecular attack of the hydroperoxide group.

The treatment of unsaturated monoperoxyketals $\mathbf{2 5 7}, \mathbf{2 6 0}$, and $\mathbf{2 6 3}$ (prepared by ozonolysis of 256, 259, and 262 in methanol, respectively) with such donors of halonium ions such as $N$-iodosuccinimide (NIS), $\mathrm{I}_{2} / t$-BuOK, or bis(symcollidine)iodonium hexafluorophosphate gave iodine-containing 1,2-dioxanes 258, 261, and 264, in moderated yields (Scheme 73) [333]. It should be noted that attempts to synthesize related peroxides with $N$-bromosuccinimide failed [333].

In the studies [334,335] iodine-containing 1,2-dioxanes 266a-c, 268, and 270a,b were synthesized from the corresponding hydroperoxyalkenes 265a-c, 267, and 269a,b with bis(symcollidine)iodonium hexaflulorophosphate (BCIH) in the cyclization step (Scheme 74).

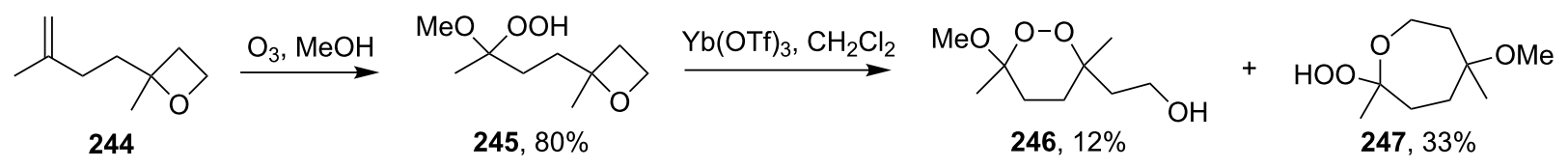

Scheme 70: Inramolecular cyclization with oxetane-ring opening.

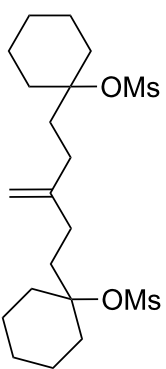

248
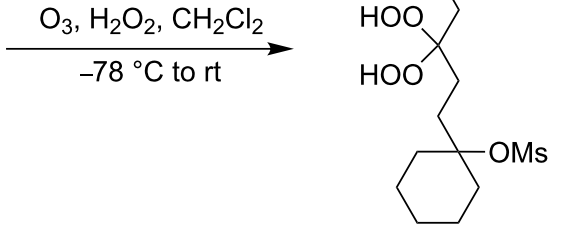

$249,76 \%$

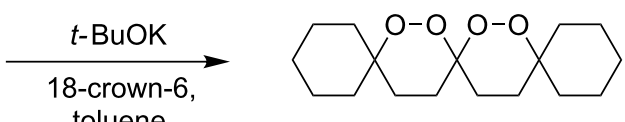

$227,80 \%$ 


$$
\begin{aligned}
& \overbrace{2}^{\stackrel{\mathrm{OMs}}{\stackrel{\mathrm{OPr}}{3} \mathrm{SiO}}} \underset{\begin{array}{c}
-78^{\circ} \mathrm{C} \text { to rt } \\
8 \%
\end{array}}{\stackrel{\mathrm{O}_{3}, \mathrm{MeOH}, \mathrm{CH}_{2} \mathrm{Cl}_{2}}{\longrightarrow}} \\
& 250
\end{aligned}
$$$$
\overbrace{2}^{\mathrm{iPr}} \mathrm{SiO}
$$$$
\underset{\substack{18 \text {-crown-6, } \\ \text { toluene }}}{\stackrel{t \text {-BuOK }}{\longrightarrow}}
$$

251a<smiles>C#CCC(OC)(OC)OCC(C)COCCCC</smiles>

252a, $79 \%$

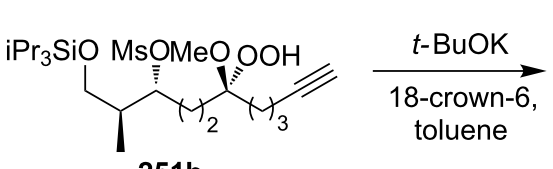

251b

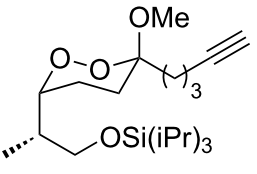

252b, $86 \%$

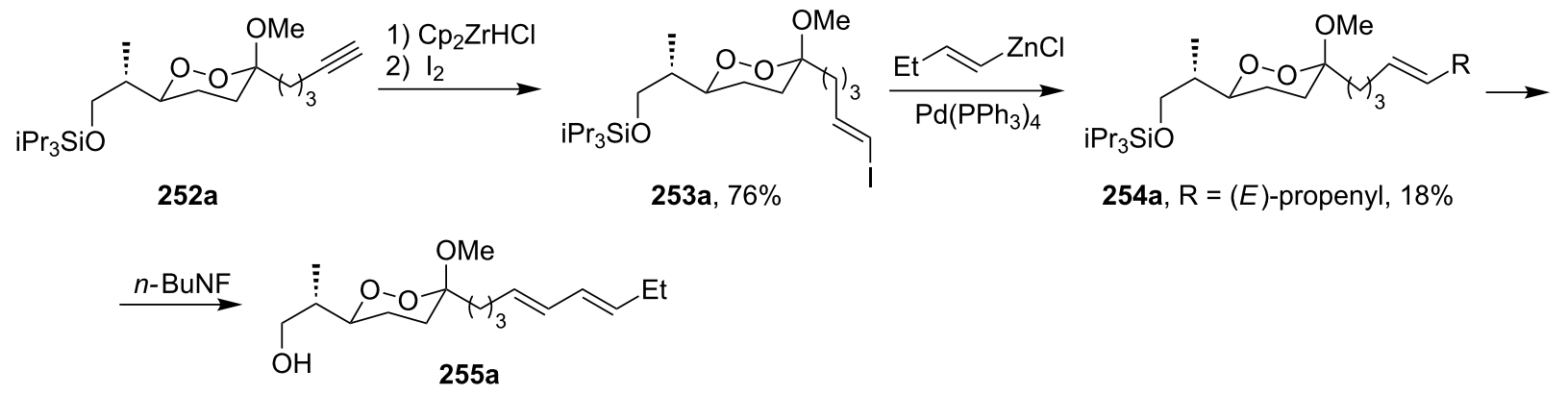

$\mathrm{Cp}_{2} \mathrm{ZrHCl}$ - zirconocene chloride hydride (Schwartz's reagent)

Scheme 72: Synthesis of 1,2-dioxane $\mathbf{2 5 5 a}$, a structurally similar compound to natural peroxyplakoric acids.<smiles>C=C(C)CC1CCCCC1=COC</smiles>

256<smiles>C=C(C)CC1CCCCC1(O)OC</smiles>

$257,76 \%$

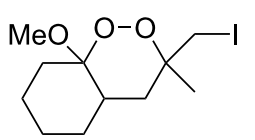

258 $1^{\oplus}$ source:

$\mathrm{N}$-iodosuccinimide $\mathrm{I}_{2} / t-\mathrm{BuOK}$ bis-(sym-collidine)iodine(I) hexafluorophosphate
Yield 258

$14 \%$

$14 \%$

$29 \%$<smiles>C=C(C)CCC(C)=COC(C)OC(C)C</smiles>

259<smiles>C=C(C)CCC(C)(OC)OO</smiles>

$260,69 \%$
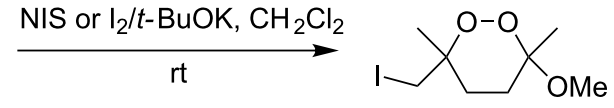

261, 28\%

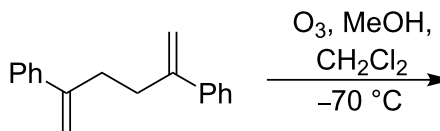

262

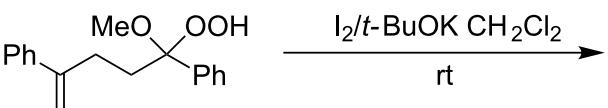

263, $42 \%$<smiles>COC1(c2ccccc2)CCC(CI)(c2ccccc2)OO1</smiles>

$264,30 \%$ 
<smiles>[R]C1CCC(C(=C)C)CC1([R])OO</smiles>

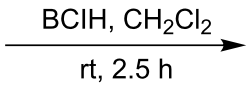

a: $\mathrm{R}_{1}=\mathrm{H}, \mathrm{R}_{2}=\mathrm{MeO}$

b: $\mathrm{R}_{1}=\mathrm{Me}, \mathrm{R}_{2}=\mathrm{MeO}$

c: $R_{1}=H, R_{2}=M e$<smiles>CC(=O)CC1CCCCC1O</smiles>

267
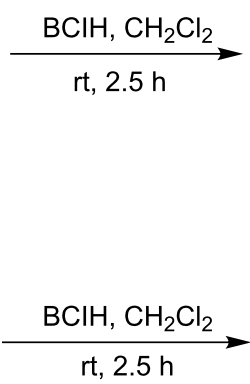

a: $\mathrm{R}_{3}=\mathrm{CO}_{2} \mathrm{Et}$

b: $\mathrm{R}_{3}=\mathrm{H}$

$\mathrm{rt}, 2.5 \mathrm{~h}$

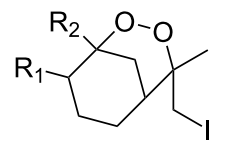

266a, $26 \%$

266b, 33\%

266c, $23 \%$<smiles>[R3]C=C1CCCC(C(C)(C)O)C1</smiles>

269a,b

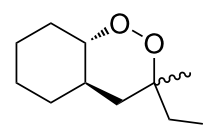

$268,43 \%$

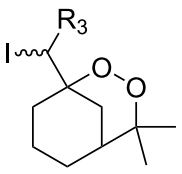

270a, $53 \%$ 270b, $52 \%$
Scheme 74: Use of $\mathrm{BCIH}$ in the intramolecular cyclization.

\section{9. $\mathrm{Pd}(\mathrm{II})$-catalyzed cyclization}

The palladium-catalyzed cyclization of $\delta$-unsaturated hydroperoxides 271 represents a new route to 1,2-dioxane cyclic compounds 272 (Scheme 75). The cyclization was performed in toluene, 1,4-dioxane, or 1,2-dichloroethane at $80^{\circ} \mathrm{C}$ for $3 \mathrm{~h}$ in the presence of $p$-benzoquinone or silver carbonate as the oxidizing agent for $\operatorname{Pd}(0)$ that was formed in the catalytic cycle. To the best of our knowledge, this method is the first example of a palladium acetate-catalyzed synthesis of cyclic peroxides [336].

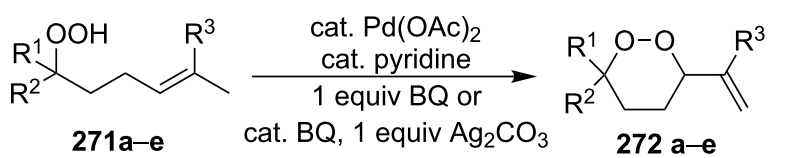

a: $\mathrm{R}^{1}=\mathrm{PhCH}_{2} \mathrm{CH}_{2}, \mathrm{R}^{2}=\mathrm{Me}, \mathrm{R}^{3}=\mathrm{Me} \quad 35 \%$

b: $\mathrm{R}^{1}=\mathrm{PhCH}_{2} \mathrm{CH}_{2}, \mathrm{R}^{2}=\mathrm{OMe}, \mathrm{R}^{3}=\mathrm{H} \quad 34 \%$

c: $\mathrm{R}^{1}=4-\mathrm{MeC}_{6} \mathrm{H}_{4}, \mathrm{R}^{2}=\mathrm{Me}, \mathrm{R}^{3}=\mathrm{Me} \quad 30 \%$

$\mathrm{d}: \mathrm{R}^{1}=\mathrm{Me}, \mathrm{R}^{2}=\mathrm{Me}, \mathrm{R}^{3}=\mathrm{CO}_{2} \mathrm{Et} \quad 31 \%$

e: $R^{1}=\mathrm{Me}, \mathrm{R}^{2}=\mathrm{OMe}, \mathrm{R}^{3}=\mathrm{CO}_{2} \mathrm{Et} \quad 30 \%$

Scheme 75: Palladium-catalyzed cyclization of $\delta$-unsaturated hydroperoxides 271 a-e.

\subsection{Acid-mediated cyclizations of peroxides}

The intramolecular cyclization of unsaturated peroxyacetals 273a-d in the presence of $\mathrm{TiCl}_{4}$ or $\mathrm{SnCl}_{4}$ occurs via formation of peroxycarbenium ions to give methoxy- and chlorinecontaining dioxanes $\mathbf{2 7 4 a - d}$ as the reaction products (Scheme 76) [257].

The treatment of endoperoxides 275a-d with allyltrimethylsilane in the presence of catalytic amounts of trimethylsilyl triflate or $\mathrm{SnCl}_{4}$ gave bicyclic 1,2-dioxanes $276 \mathbf{a}-\mathbf{d}$ (Scheme 77) [337].<smiles>[R16]C([R2])([R2])OCCC=C(C)C</smiles>

$\begin{array}{llllllc} & \mathrm{R}^{1} & \mathrm{R}^{2} & \mathrm{R}^{3} & \mathrm{M} & \mathrm{X} & \text { Yield 274 } \\ \text { a: } & \mathrm{Me} & \mathrm{Me} & \mathrm{Me} & \mathrm{Sn} & \mathrm{Cl} & 73 \% \\ \text { b: } & \mathrm{Me} & \mathrm{Me} & \mathrm{Et} & \mathrm{Ti} & \mathrm{Cl} & 46 \% \\ \text { c: } & \mathrm{Bu} & \mathrm{H} & \mathrm{Me} & \mathrm{Sn} & \mathrm{OMe} & 68 \% \\ \text { d: } & \mathrm{PhCH}_{2} & \mathrm{H} & \mathrm{Me} & \mathrm{Ti} & \mathrm{OMe} & 20 \%\end{array}$

Scheme 76: Intramolecular cyclization of unsaturated peroxyacetals $\mathbf{2 7 3 a - d . ~}$

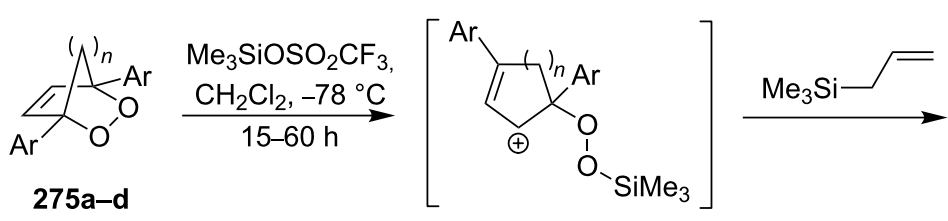

276a $n=1, \mathrm{Ar}=\mathrm{Ph}, 53 \%$

276b $n=1, \mathrm{Ar}=4-\mathrm{FC}_{6} \mathrm{H}_{4}, 60 \%$

276c $n=2, \mathrm{Ar}=\mathrm{Ph}, 10 \%$

276d $n=2, \mathrm{Ar}=4-\mathrm{FC}_{6} \mathrm{H}_{4}, 48 \%$ 
The electrophilic center of the peroxycarbenium ion produced by the decomposition of molozonide can be trapped by the hydroperoxide group of the molecule. This type of cyclization was used as the basis for the synthesis of hydroperoxidecontaining 1,2-dioxanes. The ozonolysis of 1-hydroperoxy-1methoxy-2-methyl-5-(prop-1-en-2-yl)cyclohexane (277) in a trifluoroethanol/dichloromethane mixture through formation of molozonide 278 and peroxycarbenium ion 279 finally afforded (6S)-6-hydroperoxy-1-methoxy-2,6-dimethyl-7,8dioxabicyclo[3.3.1]nonane (280) (Scheme 78) [334]. The intramolecular cyclization of intermediate $\mathbf{2 7 9}$ is only possible if the hydroperoxide group is in a particular spatial arrangement [334].

Under these conditions, ethyl 2-(3-(2-hydroperoxypropan-2yl)cyclohexylidene)acetate hydroperoxide (281) and ethyl 2-(3(1-hydroperoxy-1-methoxyethyl)cyclohexylidene)acetate hydroperoxide $\mathbf{( 2 8 3 )}$ react to form dioxanes, $(1 S, 5 S)-1$ - hydroperoxy-4,4-dimethyl-2,3-dioxabicyclo[3.3.1]nonane (282), (1S,4S,5S)-1-hydroperoxy-4-methoxy-4-methyl-2,3-dioxabicyclo[3.3.1]nonane (284a), and (1S,4R,5S)-1-hydroperoxy-4methoxy-4-methyl-2,3-dioxabicyclo[3.3.1]nonane (284b) (Scheme 79) [338].

Under similar conditions, the reaction of 5-hydroperoxy-5-(2methoxyethoxy)-2-methylhex-1-ene (285) in $\mathrm{AcOH} / \mathrm{CH}_{2} \mathrm{Cl}_{2}$ produced 3-hydroperoxy-6-(2-methoxyethoxy)-3,6-dimethyl1,2-dioxane (286) (Scheme 80) [270].

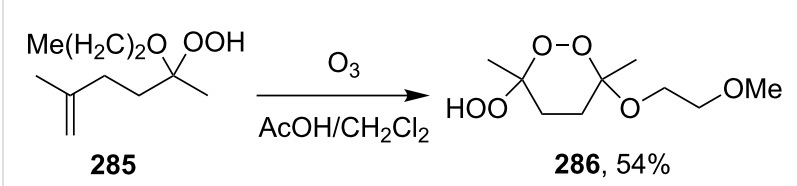

Scheme 80: Preparation of 1,2-dioxane 286.<smiles>C=C(C)C1CCC(C)C(O)(O)C1C</smiles>

277

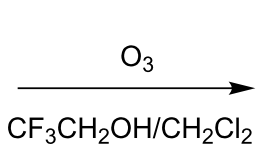

$\mathrm{CF}_{3} \mathrm{CH}_{2} \mathrm{OH} / \mathrm{CH}_{2} \mathrm{Cl}_{2}$

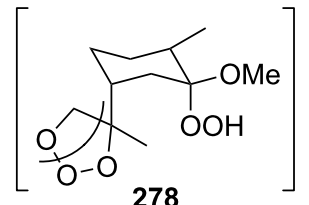

278<smiles>COC(O)(O)[C@H]1CC[C@@H](CC=O)CC1C</smiles>

279

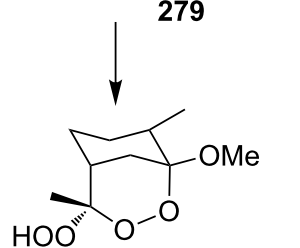

$280,42 \%$

Scheme 78: Intramolecular cyclization using the electrophilic center of the peroxycarbenium ion 279<smiles>CCOC(=O)C=C1CCCC(C(C)(C)O)C1</smiles>

281<smiles>CCOC(=O)C=C1CCCC(C(C)(O)OC)C1</smiles>

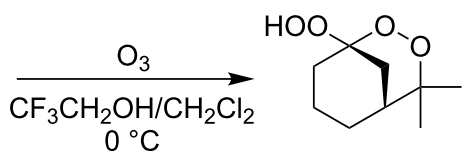

$282,91 \%$

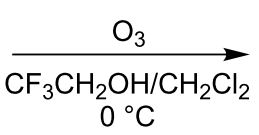

$\mathrm{O}^{\circ} \mathrm{C}$
$\mathrm{HOO}$<smiles>CO[C@]1(C)OOC23CCCC(C2)C[C@]1(C)O3</smiles>

284a, $38 \%$<smiles>CO[C@H]1C[C@@H]2CCCC(O)(C2)OO1</smiles>

$284 b, 43 \%$ 


\subsection{Other methods for the synthesis of 1,2-diox-} anes

The di(tert-butyl)peroxalate-initiated radical cyclization of unsaturated 2 - (3-hydroperoxypropyl)-6,6dimethylbicyclo[3.1.1]hept-2-ene hydroperoxide (287) in the presence of oxygen gave 1,2-dioxane (289). The reaction proceeds through formation of compound $\mathbf{2 8 8}$ containing a hydroperoxide group, which is transformed into a carbonyl group by treatment with $\mathrm{Ac}_{2} \mathrm{O} /$ pyridine (Scheme 81) [232]. The yield of $\mathbf{2 8 9}$ was $14 \%$ based on $\mathbf{2 8 7}$.

The original cyclization occurs during the oxidation of 1,4betaines 291a-d prepared from dienones 290a-d containing an azide group in the side chain. The reaction yields peroxidebridged indolizinediones 292a-d (Scheme 82) [339].

\subsection{Structural modifications, in which 1,2-dioxane ring remains intact}

This section deals with syntheses of compounds exhibiting high antimalarial activity that is comparable with or higher than that of artemisinin.

$N$-(2-(7-Chloroquinolin-4-ylamino)ethyl)-2-((S)-6,6-dimethyl1,2-dioxan-3-yl)propanamide (294) containing the aminoquinoline moiety that is characteristic for antiparasitic compounds was synthesized by the following series of steps: reduction of the double bond in the presence of the peroxide group (transformation of ethyl 2-(6,6-dimethyl-1,2-dioxan-3-yl)acrylate (272d) into ethyl 2-((S)-6,6-dimethyl-1,2-dioxan-3-yl)propanoate $(\mathbf{2 9 3}))$, alkaline hydrolysis, and amidation (Scheme 83) [336].<smiles>OCCCC1=CCC2CC1C2</smiles>

287
$\mathrm{O}_{2}$, $\underset{\text { benzene }}{\stackrel{\text { di-tert-butyl peroxalate }}{\longrightarrow}}$<smiles>OOC1CCCC[C@]12CCCCO2</smiles>
$\mathrm{Ac}_{2} \mathrm{O} /$ pyridine

288<smiles>C[C@]12CCC(CC1=O)OC21CCCOO1</smiles>

289

Scheme 81: Di(tert-butyl)peroxalate-initiated radical cyclization of unsaturated hydroperoxide 287.<smiles>[R]C=C([R10])C(=O)C(=C)CCCN</smiles>

a: $R^{1}=M e, R^{2}=P h$

b: $R^{1}=M e, R^{2}=H$

c: $R^{1}=R^{2}=-\left(\mathrm{CH}_{2}\right)_{3}-$

d: $R^{1}=R^{2}=-\left(\mathrm{CH}_{2}\right)_{4}-$

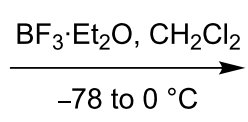

-78 to $0^{\circ} \mathrm{C}$

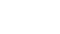
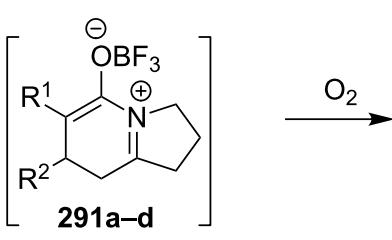

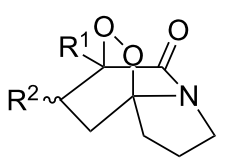

292a, $72 \%$

292b, $69 \%$

292c, $36 \%$

292d, $60 \%$

Scheme 82: Oxidation of 1,4-betaines 291a-d<smiles>C=C(CC)C1CCC(C)(C)OO1</smiles><smiles>[X]OC(=O)/N=N/C(=O)O[Na]</smiles>

272d
$\mathrm{EtO}_{2} \mathrm{C}$<smiles>CC(C)C1(C(F)F)CCC(C)(C)OO1</smiles>

$293,80 \%$
1) $1 \mathrm{M} \mathrm{LiOH}, \mathrm{MeOH}$

2) $\mathrm{EtN}=\mathrm{C}=\mathrm{N}\left(\mathrm{CH}_{2}\right)_{3} \mathrm{NMe}_{2} \quad \mathrm{H}_{2} \mathrm{~N} \sim \mathrm{NH}$<smiles>[Y]c1ccc2c(c1)nnn2O</smiles><smiles>CC(C(=O)NCCNc1ccnc2cc(Cl)ccc12)[C@@]1(C)CCC(C)(C)OO1</smiles> 
The synthesis of the sulfonyl-containing 1,2-dioxane 2-(benzyloxy)-2,6-dimethyl-6-(phenylsulfonylmethyl)-7,8dioxabicyclo[3.3.1]nonane )297a), included the following steps: oxidation of the sulfide group in 2,6-dimethyl-6-(phenylthiomethyl)-7,8-dioxabicyclo[3.3.1]nonan-2-ol (295) to form 2,6di me thy $1-6-($ p he ny 1 s u 1 fon y 1 m e thy 1$)-7,8-$ dioxabicyclo[3.3.1] nonan-2-ol (296) followed by the isolation of the isomer (6R)-2,6-dimethyl-6-(phenylsulfonylmethyl)-7,8dioxabicyclo[3.3.1]nonan-2-ol (296a) and benzylation of the latter to obtain the target peroxide 297a (Scheme 84) [107].

Methyl 2-(6-methoxy-6-pentyl-1,2-dioxan-3-yl)acetate (298) was enzymatically hydrolyzed to 2-(6-methoxy-6-pentyl-1,2dioxan-3-yl)acetic acid (299). The next step in the synthesis of target compound $\mathbf{3 0 1}$ involved the two-step amidation via the intermediate formation of perfluorophenyl 2-(6-methoxy-6pentyl-1,2-dioxan-3-yl)acetate (300) (Scheme 85) [110].

The enzymatic hydrolysis step was necessary because attempts to hydrolize ester 298 under alkaline conditions ( $\mathrm{LiOH}$ in dimethyl sulfoxide) failed and led to peroxide ring-opening [110].

\section{Synthesis of 1,2-dioxenes}

\subsection{Reaction of 1,3-dienes with singlet oxygen}

The reaction of singlet oxygen with the 1,3-diene system can proceed by the following pathways: the $[4+2]$-cycloaddition, the singlet-oxygen-ene reaction, and the $[2+2]$-cycloaddition to form dioxetanes. The reaction pathway depends on the nature of the solvent, and on electronic and steric factors. However, the $[4+2]$-cycloaddition $\left(\mathbf{3 0 2}+{ }^{1} \mathrm{O}_{2}\right)$ occurs in most cases, and this reaction is frequently used for the synthesis of the 1,2dioxene system 303 (Scheme 86). Table 18 gives examples of 1,2-dioxenes synthesized by the reaction of singlet oxygen with 1,3-diene systems.
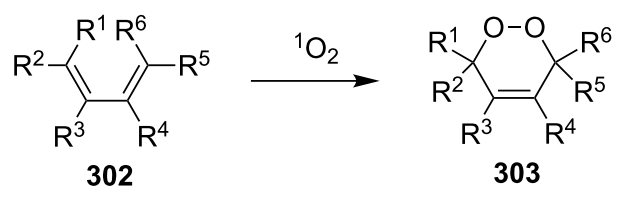

Scheme 86: Reaction of singlet oxygen with the 1,3-diene system 302.

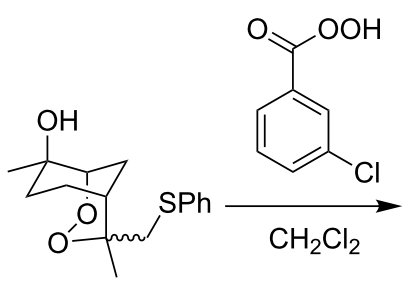

295

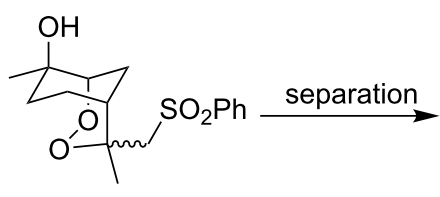

296, $94 \%$

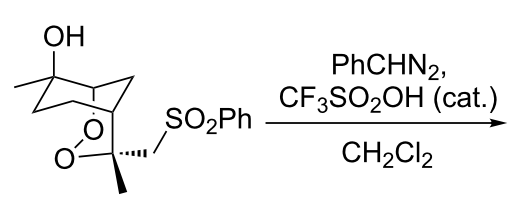

296a

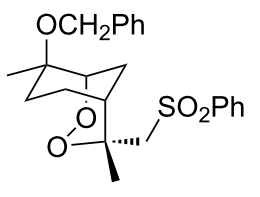

$297 a, 86 \%$

Scheme 84: Synthesis of the sulfonyl-containing 1,2-dioxane.<smiles>CCCCC1(OC)CCC(CC(=O)OC)OO1</smiles>

298

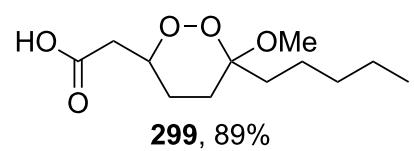

$299,89 \%$

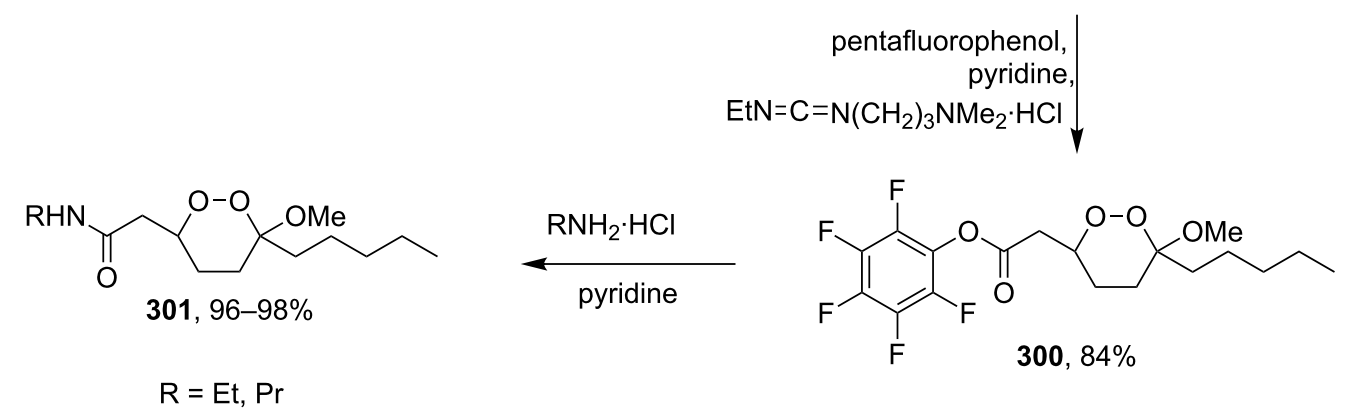


Table 18: Examples of the use of ${ }^{1} \mathrm{O}_{2}$ in the synthesis of 1,2-dioxenes.

Alkene 302

$\mathrm{R}$<smiles>Cn1ccc(C2=C([Te])C(C)(C)CO2)cc1=O</smiles>

$\mathrm{R}=\mathrm{PhCH}_{2}, \mathrm{H}, \mathrm{Me}$

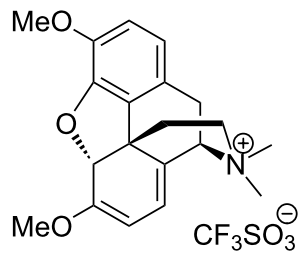<smiles>Cc1ccc(C)c2nonc12</smiles><smiles></smiles>

$\mathrm{X}=\mathrm{O}, \mathrm{CH}=\mathrm{CH}$<smiles>CCOC(=O)C1C=CC2=C(C=C1)OCO2</smiles><smiles>[R]c1ccc2ccccc2c(=O)c1</smiles>

$\mathrm{R}=\mathrm{H}, \mathrm{CO}_{2} \mathrm{Et}$<smiles>C1=CC2=C(C=CC1)OCCO2</smiles><smiles>O=c1ccc2c(cc1)OCCO2</smiles><smiles>[R]C1=CCc2ccccc2C=C1</smiles>

$\mathrm{R}=\mathrm{CO}_{2} \mathrm{Et}, \mathrm{CH}_{3}$
$\mathrm{O}_{2}, h \mathrm{v}$

tetraphenylporphyrin, $\mathrm{CH}_{2} \mathrm{Cl}_{2},-78^{\circ} \mathrm{C}, 1 \mathrm{~h}$

$\mathrm{O}_{2}, h \mathrm{v}$

tetraphenylporphyrin, $\mathrm{CH}_{2} \mathrm{Cl}_{2},-78{ }^{\circ} \mathrm{C}, 2 \mathrm{~h}$

$\mathrm{O}_{2}, \mathrm{hv}$, fullerene $\mathrm{C}_{60}$

$\mathrm{O}_{2}, h \mathrm{v}$

tetraphenylporphyrin, $\mathrm{CCl}_{4}$

$\mathrm{O}_{2}, h \mathrm{v}$

tetraphenylporphyrin, $\mathrm{CCl}_{4}, \mathrm{rt}, 30 \mathrm{~min}$

$\mathrm{O}_{2}, h \mathrm{v}$

tetraphenylporphyrin, $\mathrm{CCl}_{4}, \mathrm{rt}, 18-20 \mathrm{~h}$

$\mathrm{O}_{2}, h \mathrm{v}$,

tetraphenylporphyrin, $\mathrm{CCl}_{4}, 10^{\circ} \mathrm{C}, 1.5 \mathrm{~h}$

$\mathrm{O}_{2}, h \mathrm{v}$,

tetraphenylporphyrin, $\mathrm{CHCl}_{3}, 10^{\circ} \mathrm{C}, 45 \mathrm{~min}$

$\mathrm{O}_{2}, h \mathrm{v}$

tetraphenylporphyrin, $\mathrm{CCl}_{4}, \mathrm{rt}, 24 \mathrm{~h}$ to $9 \mathrm{~d}$

$\mathrm{O}_{2}, h \mathrm{v}$

tetraphenylporphyrin,

$\mathrm{CH}_{2} \mathrm{Cl}_{2},-10{ }^{\circ} \mathrm{C}, 6 \mathrm{~h}$ $\mathrm{CDCl}_{3}, 0^{\circ} \mathrm{C}, 2 \mathrm{~h}$

1,2-Dioxene 303<smiles>[R]N1C=CC2=C3OCC(C)(C)C3([Y18])OOC2C1=O</smiles>

100

[340]

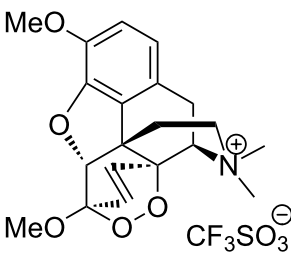

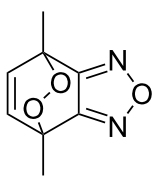

[342]

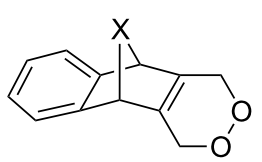

75

[343]<smiles>CCOC(=O)C1C=CC23COC(=CC2O1)OO3</smiles><smiles>[R]C1=CC2OOC1C(=O)c1ccccc12</smiles><smiles>C1=CC23OCCOC2=CC(O1)OO3</smiles><smiles>O=C1C=CC23OCCOC2=CC(OO3)O1</smiles><smiles>[R]C1=CC2OOC1Cc1ccccc12</smiles>
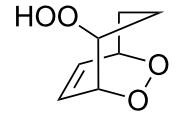

1) $\mathrm{O}_{2}, h v$, Rose Bengal,<smiles>CC/C=C/[C@H](CC)C[C@H](C)C/C(=C/C(=C/CC(=O)O)CC)CC</smiles><smiles>CC/C=C/[C@H](CC)C[C@H](C)C[C@]1(CC)C=C(CC)C(CC(=O)OC)OO1</smiles> 
Table 18: Examples of the use of ${ }^{1} \mathrm{O}_{2}$ in the synthesis of 1,2-dioxenes. (continued)

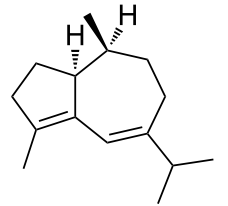<smiles>[R]C1CC=C(C=C)CCON1C(=O)OCC</smiles>

$m=1,2$

$n=0,1,2$

$\mathrm{R}=\mathrm{H}, \mathrm{Me}, \mathrm{Ph}$

$\mathrm{PhCH}_{2} \mathrm{OCH}_{2}$<smiles>C=C(CO[Pb](C)(C)C)C1=CC=CN(C(=O)OC(C)C)OC1</smiles>

$n=1,2$<smiles>[R]C=CC=CCCC([R])([R])O</smiles>

$\mathrm{R}^{1}=\mathrm{Ph}, p-\mathrm{MeOC}_{6} \mathrm{H}_{4}$,

$p-\mathrm{BrC}_{6} \mathrm{H}_{4}$, naphthyl

$\mathrm{R}^{2}=\mathrm{H}, \mathrm{Me}, \mathrm{Ph}$

$\mathrm{R}^{3}=\mathrm{H}, \mathrm{Me}, \mathrm{Ph}$<smiles>C[C@H]1C(=O)O[C@@H]2[C@H]3C=CC=C[C@]3(C)CC[C@@H]21</smiles><smiles>CC(/C=C/C1=CCCCC1(C)C)=C\C=C\C(C)=C\C(=O)O</smiles>

retinoic acid

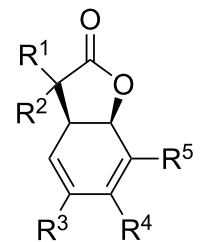

$\mathrm{R}^{1}, \mathrm{R}^{2}=-\left(\mathrm{CH}_{2}\right)_{5^{-}}, \mathrm{CH}_{3}$

$\mathrm{R}^{3}=\mathrm{H}$, iPr, $t-\mathrm{Bu}, \mathrm{PhO}$

$\mathrm{R}^{4}=\mathrm{Me}_{3} \mathrm{Si}$

$\mathrm{R}^{5}=\mathrm{H}, \mathrm{PhO}$

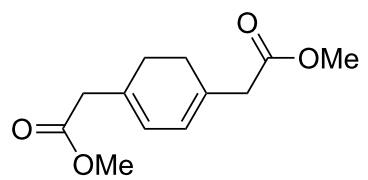

1) $\mathrm{O}, h \mathrm{v}$ methylene blue, $\mathrm{CH}_{2} \mathrm{Cl}_{2}, 15^{\circ} \mathrm{C}$,

$30 \mathrm{~min}$

2) $\mathrm{PPh}_{3}$, acetone, rt $40 \mathrm{~min}$

$\mathrm{O}_{2}, h v$, Rose Bengal, $\mathrm{MeCN}, 0{ }^{\circ} \mathrm{C}, 6-16 \mathrm{~h}$

, hv, Rose Bengal, $\mathrm{MeOH} / \mathrm{CH}_{2} \mathrm{Cl}_{2}$ (1/19), $0{ }^{\circ} \mathrm{C}, 6 \mathrm{~h}$

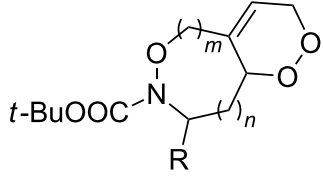

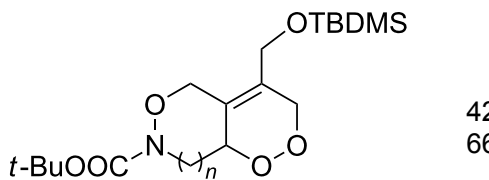

$$
n=1,2
$$

$\mathrm{O}_{2}$, hv, Rose Bengal, $\mathrm{CH}_{2} \mathrm{Cl}_{2}, 6 \mathrm{~h}$<smiles>[R]C1C=C[C@@H](CCC([R])([R])O)OO1</smiles><smiles>C[C@H]1C(=O)O[C@@H]2[C@H]3[C@@H]4C=CC(OO4)[C@]3(C)CC[C@@H]21</smiles>
tetraphenylporphyrin, benzene, $18 \mathrm{~h}$<smiles>CC(/C=C/C=C(\C)[C@H]1C=C2C(C)(C)CCC[C@]2(C)OO1)=C([Hg])C(=O)O</smiles>

[186-190]

, hv, Rose Benga $\mathrm{EtOH}, 10^{\circ} \mathrm{C}, 70 \mathrm{~min}$

$\mathrm{O}_{2}, h \mathrm{v}$,

tetraphenylporphyrin, $\mathrm{CH}_{2} \mathrm{Cl}_{2}$

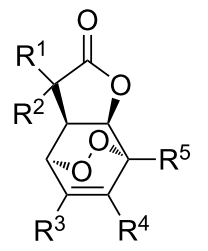

13-95

[191-195]

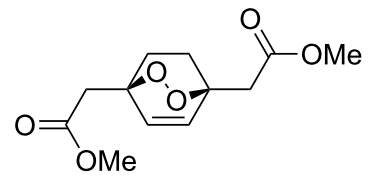

89

[354]

$\mathrm{CH}_{2} \mathrm{Cl}_{2}$ 
<smiles>[R]C1=CC([R])=C([R])C(OC)(OC)C1=O</smiles>

$\mathrm{R}^{1}=\mathrm{H}, \mathrm{Me}, \mathrm{MeO}$

$\mathrm{R}^{2}=\mathrm{H}$, iPr, $t-\mathrm{Bu}$,

$\left(\mathrm{OCH}_{2} \mathrm{C}\left(\mathrm{CH}_{3}\right)_{2} \mathrm{CH}_{2} \mathrm{O}\right) \mathrm{CH}$

$\mathrm{R}^{3}=\mathrm{H}, \mathrm{Me}, t-\mathrm{Bu}$
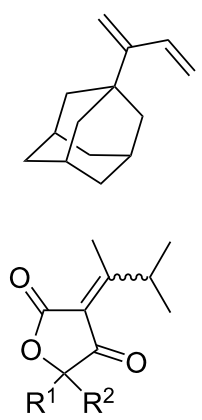

$\mathrm{R}^{1}, \mathrm{R}^{2}=-\left(\mathrm{CH}_{2}\right)_{5}^{-}$

$\mathrm{R}^{1}, \mathrm{R}^{2}=-\left(\mathrm{CH}_{2}\right)_{4}-$

$\mathrm{R}^{1}, \mathrm{R}^{2}=\mathrm{Ph}, \mathrm{H}$<smiles>[R]C([R])C=C1C(=O)C(C)(C)C(=O)C(C)(C)C1=O</smiles>

$\mathrm{R}^{1}=\mathrm{Me}, \mathrm{CH}_{2} \mathrm{OSit}-\mathrm{Bu}(\mathrm{Ph})_{2}$

$\mathrm{R}^{2}=\mathrm{Me}, \mathrm{Ph}, \mathrm{CH}_{2} \mathrm{OSit}-\mathrm{Bu}(\mathrm{Ph})_{2}$<smiles>CC1(C)C(=O)C(C=C2CC3C=CC2C3)=C(O)C(C)(C)C1=O</smiles><smiles>CC1(C)OCC(C=C2C(=O)C(C)(C)C(=O)C(C)(C)C2=O)O1</smiles><smiles>[R]C1([R2])OC2OC3OC2OC3C1/C=C/C(C)=O</smiles>

$\mathrm{R}^{1}=\mathrm{Me}, \mathrm{CCl}_{3}, \mathrm{H}$

$\mathrm{R}^{2}=\mathrm{Me}, \mathrm{CCl}_{3}, \mathrm{H}$

$\mathrm{R}^{3}=\mathrm{Ac}, \mathrm{Me}$
$\mathrm{O}_{2}, h \mathrm{v}$,

tetraphenylporphyrin,

$\mathrm{CHCl}_{3}$ or Rose

Bengal, $\mathrm{MeOH},-15$

to $0{ }^{\circ} \mathrm{C}, 1-4 \mathrm{~h}$

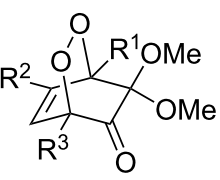

70-92

[355]

$\mathrm{O}_{2}, h v$, Rose Bengal, $\mathrm{CH}_{2} \mathrm{Cl}_{2}, 6 \mathrm{~h}$

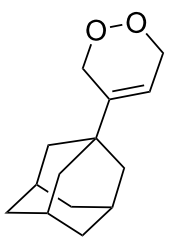

91

[356]

air, sunlight, $\mathrm{CHCl}_{3}$, rt, $5 \mathrm{~d}$ or $\mathrm{O}_{2}, h \mathrm{v}$, $\mathrm{CH}_{2} \mathrm{Cl}_{2}, \mathrm{CuSO}_{4}$, $\mathrm{TsOH}, 1 \mathrm{~h}$

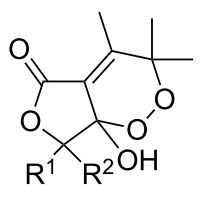

53-80

$[357,358]$

air, sunlight, $\mathrm{CHCl}_{3}$, rt, $3 \mathrm{~d}$<smiles>[R]C1([R])C=C2C(=O)C(C)(C)C(=O)C(C)(O)C2(O)OO1</smiles>

60-85

$[359,360]$<smiles>CC1(C)C(=O)C2=C[C@]3(C[C@H]4C=C[C@H]3C4)OO[C@]2(O)C(C)(C)C1=O</smiles>
$\mathrm{rt}, 3 \mathrm{~d}$

air, sunlight, $\mathrm{CHCl}_{3}$, rt, $6 \mathrm{~d}$<smiles>CC1(C)OCC2(C=C3C(=O)C(C)(C)C(=O)C(C)(C)C3(O)OO2)O1</smiles>

15

[119]

air, sunlight, $\mathrm{CCl}_{4}$, rt $160 \mathrm{~h}$

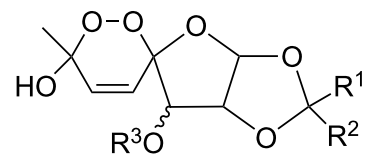


(+)-Premnalane A is a natural compound of plant origin exhibiting pronounced antimicrobial activity. The synthesis of this compound includes the following steps: oxidation of the furan ring of compound 304, the singlet-oxygen-ene reaction of the double bond-containing bicyclic compound 305, and acidinduced ketalization (Scheme 87) [362].

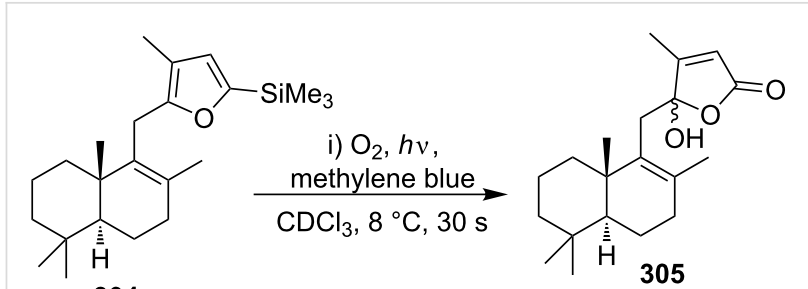
304

ii) $\mathrm{O}_{2}, h v$, tetraphenylporphine, $\mathrm{CDCl}_{3}, 2.5 \mathrm{~min}, 8^{\circ} \mathrm{C}$ iii) $p-\mathrm{TsOH}$ or $\mathrm{SiO}_{2}, 30 \mathrm{~min}$<smiles>C=C1CC[C@H]2C(C)(C)CCC[C@]2(C)[C@@]12C=C(C)[C@@]1(C2)OC(=O)C=C1C</smiles>

306<smiles>CC1=CC(=O)O[C@]12C=C1[C@H]3CCCC(C)(C)[C@@H]3CC[C@]1(C)OO2</smiles>

(+)-premnalane A and
Scheme 87: Synthesis of (+)-premnalane A and 8-epi-premnalane A.

This synthesis produced a 1:1 mixture of diastereomeric $(+)$ premnalane A and 8-epi-premnalane A in 24\% combined yield and diastereomeric 1,2-dioxolanes 306 in $49 \%$ yield. Pure (+)premnalane A was isolated by column chromatography.

\subsection{Structural modifications, in which 1,2-dioxene ring remains intact}

Diazo-containing 1,2-dioxenes 309a-e were synthesized starting from the corresponding acids $\mathbf{3 0 7} \mathbf{a}-\mathbf{e}$, which were transformed into acid chlorides $\mathbf{3 0 8}-\mathbf{a}-\mathbf{e}$ and then subjected to diazotization (Scheme 88) [363]. The 1,2-dioxenes 309a-e were used for the intramolecular insertion of carbenes, that were produced by decomposition of the diazo group, into the -O-O-bond [363].

6-Epiplakortolide $\mathrm{E}$ is a bicyclic peroxylactone that was isolated in low yield $(0.0003 \%)$ from the marine sponge Plakortis sp. The structurally related plakortolide E (Figure 4) exhibits high cytotoxicity against cancer cells and shows also activity against Toxoplasma gondii, which is the causative agent of toxoplasmosis [184,185].

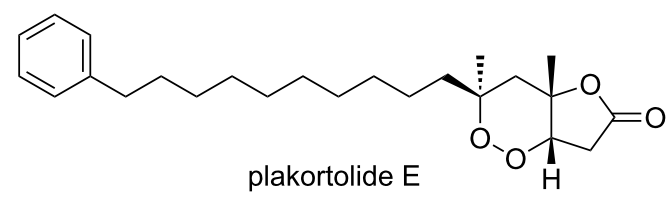

Figure 4: Plakortolide E.

6-Epiplakortolide E was synthesized by the multistep synthesis involving the oxidation of diene $\mathbf{3 1 0}$ with singlet oxygen to give two isomeric 1,2-dioxenes $311 \mathbf{a}, \mathbf{b}$, the isolation of dioxene 311a, its silyl deprotection to form alcohol 312, the oxidation of the latter to 1,2-dioxenic acid 313, the $\mathrm{I}^{+}$-induced lactonization to produce 314, and the deiodination to obtain the target product (Scheme 89) $[184,185]$. It should be noted that the cyclic peroxide compound $\mathbf{3 1 4}$ remains intact under the reductive conditions in the presence of tributylstannane; this step occurs in good yield (68\%) [184,185].

More recently, a similar approach was used for the preparation of tetrahydrofuran-containing bicyclic peroxides 318a,b. It involves the synthesis of 1,2-dioxenes 316 from dienes 315, the cation-initiated cyclization to give bicyclic compounds 317 , and the reduction with $\mathrm{Bu}_{3} \mathrm{SnH}$. $N$-Bromo- and iodosuccinimides (NBS and NIS, respectively) were used as donors of halogenide ions. Additionallay, the cyclization was successfully performed with the use of phenylselenyl chloride as the donor of $\mathrm{PhSe}^{+}$cation (Scheme 90) [364].

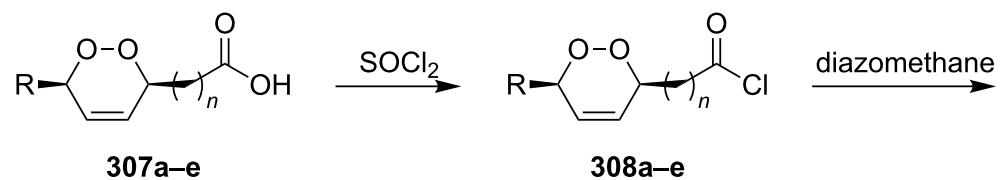

$307 a-e$

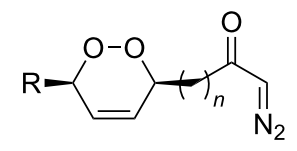

309a $\mathrm{R}=\mathrm{Me}, n=1,50 \%$

309b R $=\mathrm{Ph}, n=1,54 \%$

309c $\mathrm{R}=\mathrm{H}, n=1,55 \%$

309d $\mathrm{R}=\mathrm{Me}, n=2,61 \%$

309e $\mathrm{R}=\mathrm{Ph}, n=2,49 \%$ 
<smiles>[R]C(C)=CC(C)=CCOCC</smiles>

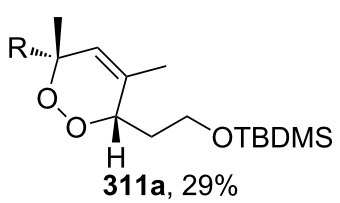

311 a, $29 \%$

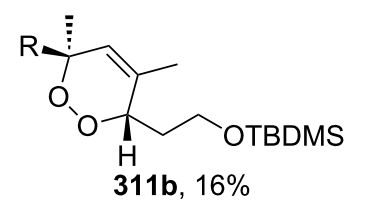

311b, $16 \%$

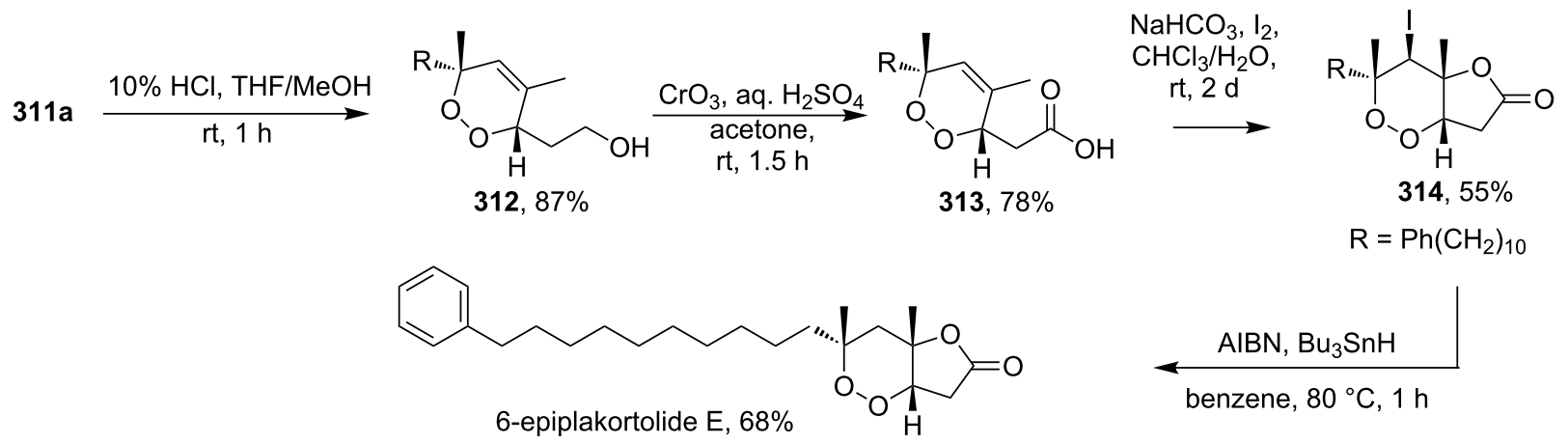

Scheme 89: Synthesis of 6-epiplakortolide E.

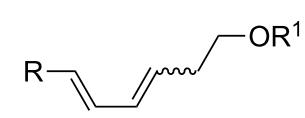

315a, $R=M e, R^{1}=$ TBDMS

315b, $R=P h, R^{1}=H$

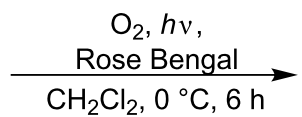

$\mathrm{CH}_{2} \mathrm{Cl}_{2}, 0^{\circ} \mathrm{C}, 6 \mathrm{~h}$

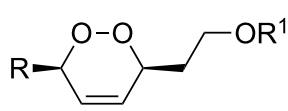

316a, $\mathrm{R}=\mathrm{Me}, \mathrm{R}^{1}=\mathrm{TBDMS}, 39 \%$

316b, $R=P h, R^{1}=H, 52 \%$

316c, $R=M e, R^{1}=H, 76 \%$
$\mathrm{MeOH}$, cat. $\mathrm{HCl}$
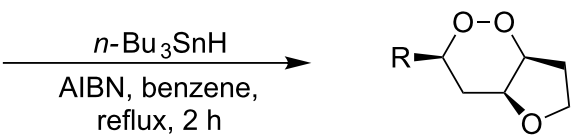

318a, $\mathrm{R}=\mathrm{Me}, 46-89 \%$

318b, R = Ph, 0-67\%

$$
\begin{aligned}
& \text { 317a, } R=M e, X=B r, 64 \% \\
& \text { 317b, } R=M e, X=I, 62 \% \\
& \text { 317c, } R=M e, X=S e P h, 85 \% \\
& \text { 317d, } R=P h, X=B r, 51 \% \\
& \text { 317e, } R=P h, X=I, 71 \% \\
& \text { 317f, } R=P h, X=S e P h, 38 \%
\end{aligned}
$$

Scheme 90: Application of $\mathrm{Bu}_{3} \mathrm{SnH}$ for the preparation of tetrahydrofuran-containing bicyclic peroxides $318 \mathbf{a}, \mathbf{b}$

Acids 307a and 307b were synthesized by oxidation of the corresponding alcohols with the bis(acetoxy)iodobenzene/ 2,2,6,6-tetramethyl-1-piperidinyl oxyl (BAIB/TEMPO) system. The cyclization to bicyclic peroxides $319 \mathbf{a}-\mathbf{f}$ containing the lactone ring was performed with the use of N-bromo- and iodosuccinimides and $\mathrm{PhSeCl}$ (Scheme 91) [364]. As in the above-considered case, the peroxide ring remains unchanged upon the reduction of the $\mathrm{C}-\mathrm{X}$ bond in compounds $\mathbf{3 1 9} \mathbf{a}-\mathbf{f}$ with $\mathrm{Bu}_{3} \mathrm{SnH}$ [364].

The double bond in the 1,2-dioxene ring of $\mathbf{3 2 1}$ was subjected to dihydroxylation with osmium tetroxide (Scheme 92) $[354,365]$. The reaction was performed in aqueous tert-butanol, acetone, or acetonitrile at room temperature. Several methods were used for the oxidation. For example, the commercially available AD-mix, a mixture consisting of $\mathrm{K}_{2} \mathrm{OsO}_{2}(\mathrm{OH})_{4}$ (catalytic amounts, a source of $\mathrm{OsO}_{4}$ ) and $\mathrm{K}_{3} \mathrm{Fe}(\mathrm{CN})_{6}$ (oxidizer), was employed for this purpose. In this reaction, $\mathrm{K}_{2} \mathrm{OsO}_{4}(0.5 \mathrm{~mol} \%)$ combined with oxidizers $\left(\mathrm{K}_{3} \mathrm{Fe}(\mathrm{CN})_{6}\right.$, $\mathrm{N}$-methylmorpholine $\mathrm{N}$-oxide, citric acid, or $\mathrm{KClO}_{3}$ ) was also used [354,365].

The epoxidation of 1,2-dioxenes $\mathbf{3 2 4}$ produced by the addition of singlet oxygen to dienes $\mathbf{3 2 3}$ was performed by treatment with $m$-chlorobenzoic acid (Scheme 93). It was shown that epoxidized dioxanes $\mathbf{3 2 5}$ and $\mathbf{3 2 6}$, as well as dioxenes 324, have 


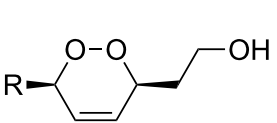

$316 b, R=P h$ 316c, $R=M e$

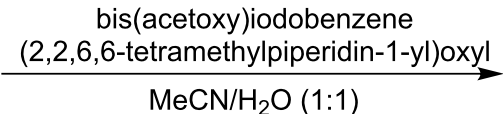

$\mathrm{MeCN} / \mathrm{H}_{2} \mathrm{O}(1: 1)$

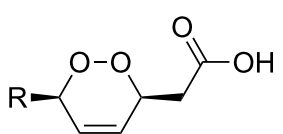

$307 a, R=M e, 84 \%$

307b, R = Ph, $81 \%$

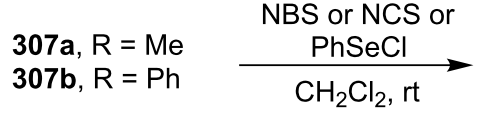

$307 a, R=M e$
$307 b, R=P h$

$\mathrm{CH}_{2} \mathrm{Cl}_{2}$, r

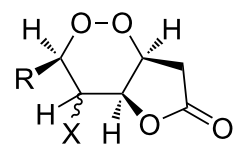

319a, $R=M e, X=B r, 69 \%$

319b, $R=M e, X=I, 76 \%$

319c, $\mathrm{R}=\mathrm{Me}, \mathrm{X}=\mathrm{SePh}, 57 \%$

319d, $R=P h, X=B r, 56 \%$

319e, $R=P h, X=I, 56 \%$

319f, $\mathrm{R}=\mathrm{Ph}, \mathrm{X}=\mathrm{SePh}, 55 \%$

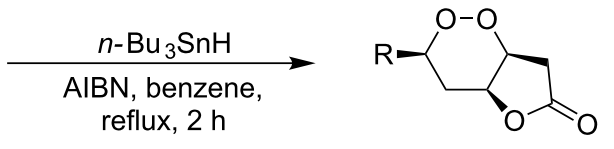

320a-f, $45-81 \%$

Scheme 91: Application of $\mathrm{Bu}_{3} \mathrm{SnH}$ for the preparation of lactone-containing bicyclic peroxides $320 \mathrm{a}-\mathbf{f}$

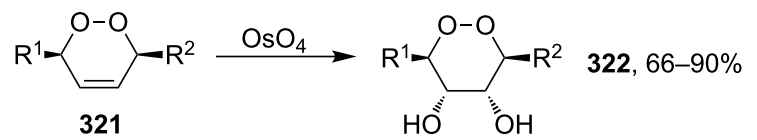

$\mathrm{R}^{1}=\mathrm{Me}$, cyclopentyl, cyclohexyl, $n$ - $\mathrm{Pr}, \mathrm{CH}_{2} \mathrm{OTBDMS}, \mathrm{CH}_{2} \mathrm{Br}, \mathrm{Ph}$ $\mathrm{R}^{2}=\mathrm{Me}, \mathrm{H}, n-\mathrm{Pr}, \mathrm{CH}_{2} \mathrm{OTBDMS}, \mathrm{CH}_{2} \mathrm{Br}, \mathrm{Ph}$

Scheme 92: Dihydroxylation of the double bond in the 1,2-dioxene ring 321 with $\mathrm{OsO}_{4}$

inhibiting activity against the causative agents of candidiasis infections Candida albicans, Candida krusei, and Candida tropicalis, that are in some cases comparable with the activity of the currently used amphotericin B, ketonazole, and nystatin [218-228]. In addition, these compounds exhibit pronounced antimalarial activity, although lower than that of artemisinin [366,367].
The cyclopropanation of the double bond in endoperoxides $\mathbf{3 2 7}$ was performed by the reaction with diazomethane in the presence of $\mathrm{Pd}(\mathrm{OAc})_{2}$ to produce 328a,b (Scheme 94) [368].

Pyridazine-containing bicyclic endoperoxides 334a-c were synthesized by the inverse-electron-demand Diels-Alder cycloaddition of dimethyl 1,2,4,5-tetrazine-3,6-dicarboxylate (329) to 1,2-dioxenes $\mathbf{3 3 0}$ followed by the elimination of dinitrogen from $331 \mathbf{a}-\mathbf{c}$ to give $332 \mathbf{a}-\mathbf{c}$, the isomerization to $333 \mathbf{a}-\mathbf{c}$, and the oxidation (Scheme 95) [369].

\section{Synthesis of 1,2,4-trioxanes}

This part is devoted to methods for the synthesis of the 1,2,4trioxane ring by the singlet-oxygen ene reaction with unsaturated alcohols, the photooxidation of enol ethers and vinyl sulfides, the [4+2]-cycloaddition of singlet oxygen to the pyran system, the Isayama-Mukaiyama peroxysilylation of unsatu-<smiles>[R]/C=C\C([R])=C/[R]</smiles>

323<smiles>[R]C1=C([R])[C@H]([R])OO[C@H]1[R]</smiles>

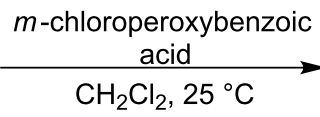

$324,27-74 \%$<smiles>[R]C1COO[C@H]([R2])[C@@]2([R2])O[C@H]12</smiles>

$325,26-68 \%$<smiles>[R][C@H]1OOC([R])([R2])[C@@H]2O[C@]21[R2]</smiles>

326, $17-41 \%$

$\mathrm{R}^{1}, \mathrm{R}^{2}, \mathrm{R}^{3}=\mathrm{H}, \mathrm{Me}$, adamantyl (Ad), $\mathrm{CH}_{2} \mathrm{Ad}, \mathrm{Ph}$, alkyl, cycloalkyl, $\mathrm{CH}_{2} \mathrm{OH}, \mathrm{CH}_{2} \mathrm{OCOAd}, \mathrm{CH}_{2} \mathrm{OCOCH}_{2} \mathrm{Ad}$, $\left(\mathrm{CH}_{2}\right)_{3} \mathrm{OH}, \mathrm{CH}_{2} \mathrm{OCH}_{2} \mathrm{Ph}, \mathrm{F}-\mathrm{Ph}, \mathrm{Cl}-\mathrm{Ph}, \mathrm{Br}-\mathrm{Ph}$, I-Ph, MeOPh 
<smiles></smiles>

327

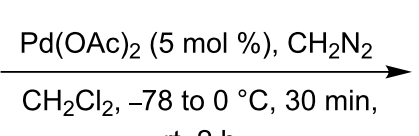

$\mathrm{rt}, 2 \mathrm{~h}$

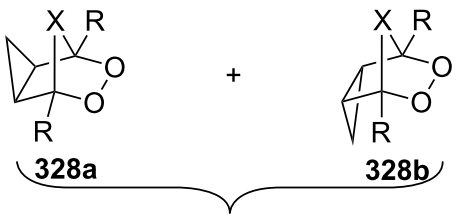

$\mathrm{R}=\mathrm{H}, \mathrm{X}=\mathrm{CH}_{2}, 58 \%(\mathbf{a}: \mathbf{b}=100: 0)$

$\mathrm{R}=\mathrm{Ph}, \mathrm{X}=\mathrm{CH}_{2}, 82 \%(\mathbf{a}: \mathbf{b}=90: 10)$

$\mathrm{R}=\mathrm{Me}, \mathrm{X}=\mathrm{CH}_{2}, 73 \%(\mathbf{a}: \mathbf{b}=100: 0)$

$\mathrm{R}=\mathrm{H}, \mathrm{X}=\mathrm{CH}_{2} \mathrm{CH}_{2}, 78 \%(\mathbf{a}: \mathbf{b}=40: 60)$

$\mathrm{R}=\mathrm{H}, \mathrm{X}=\mathrm{CH}_{2} \mathrm{CH}_{2} \mathrm{CH}_{2}, 69 \%(\mathbf{a}: \mathbf{b}=0: 100)$

$\mathrm{R}=\mathrm{H}, \mathrm{X}=\mathrm{CH}=\mathrm{CHCH}_{2}, 57 \%(\mathbf{a}: \mathbf{b}=0: 100)$

$\mathrm{R}=\mathrm{H}, \mathrm{X}=\left(\mathrm{CH}_{2}\right)_{4}, 85 \%(\mathbf{a}: \mathbf{b}=0: 100)$

$\mathrm{R}=\mathrm{Me}, \mathrm{X}=\mathrm{C}=\mathrm{C}, 92 \%(\mathbf{a}: \mathbf{b}=100: 0)$

Scheme 94: Cyclopropanation of the double bond in endoperoxides 327.

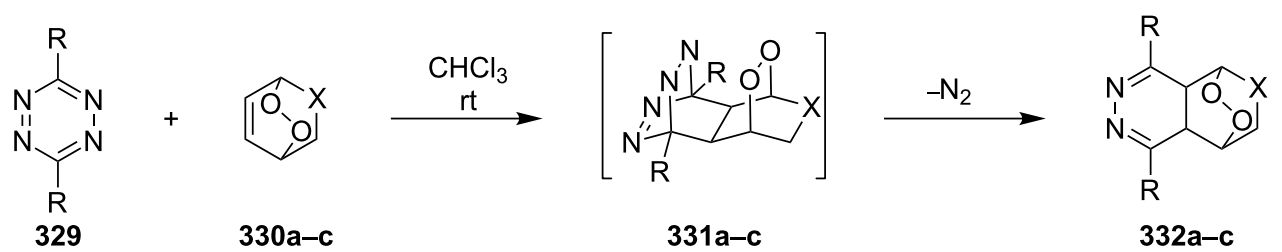

334a, $\mathrm{X}=\mathrm{CH}_{2}, 83 \%$

334b, $X=\left(\mathrm{CH}_{2}\right)_{2}, 43 \%$

334c, $\mathrm{X}=-\mathrm{CH}=\mathrm{CH}-, 19 \%$

$\mathrm{R}=\mathrm{COOMe}$

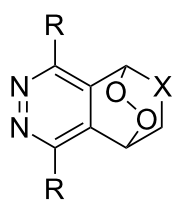

phenyliodine(III)

bis(trifluoroacetate) $\downarrow$ H-shift<smiles>[X]OC1C2OCC1C1C([R])=NNC([R])=C21</smiles>

$333 a-c$

Scheme 95: Preparation of pyridazine-containing bicyclic endoperoxides 334a-c

rated alcohols, reactions with hydrogen peroxide, and the intramolecular Kobayashi cyclization.

\subsection{Use of singlet oxygen in the synthesis of $1,2,4-$} trioxane

One of the widely used approaches to the synthesis of the 1,2,4trioxane ring $\mathbf{3 3 7}$ is based on the hydroperoxidation of unsaturated alcohols $\mathbf{3 3 5}$ with singlet oxygen (the singlet-oxygen ene reaction) and the acid-catalyzed condensation of the resulting vicinal hydroxy hydroperoxides $\mathbf{3 3 6}$ with ketones or aldehydes (acetals, orthoesters) (Scheme 96, Table 19).

The method was described for the first time by Singh in 1990 [370]. Due to a wide structural series of prepared 1,2,4-trioxane systems and the use of readily available inexpensive reagents, this is an efficient method for their synthesis.

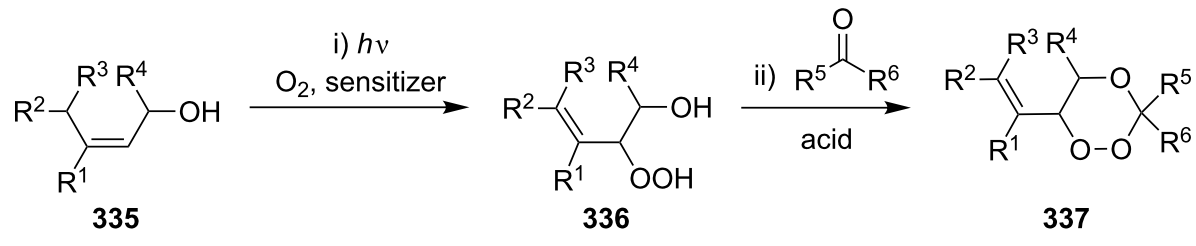

Scheme 96: Synthesis of 1,2,4-trioxanes 337 by the hydroperoxidation of unsaturated alcohols 335 with ${ }^{1} \mathrm{O}_{2}$ and the condensation of the hydroxy hydroperoxides $\mathbf{3 3 6}$ with carbonyl compounds. 
Table 19: Examples of 1,2,4-trioxanes synthesized by the singlet oxygen ene reaction.

\begin{tabular}{|c|c|c|c|c|c|}
\hline Alkene 335 & Carbonyl compound & $\begin{array}{l}\text { Reaction } \\
\text { conditions }^{a}\end{array}$ & Product 337 & $\begin{array}{l}\text { Yield } \\
\text { i) } 336, \% \\
\text { ii) } 337, \%\end{array}$ & Reference \\
\hline
\end{tabular}<smiles>CC(C)=CC(C)O</smiles><smiles>CC(C)=CCCC(C)=CCO</smiles><smiles>CC(C)=CCO</smiles>

$\mathrm{Ar}=\mathrm{Ph}, 4-\mathrm{PhC}_{6} \mathrm{H}_{4}$ 4- $\mathrm{ClC}_{6} \mathrm{H}_{4}, 4-\mathrm{MeOC}_{6} \mathrm{H}_{4}$ 1-naphthyl,

2-naphthyl,

2-phenanthrenyl,

3-phenanthrenyl, 2-fluorenyl

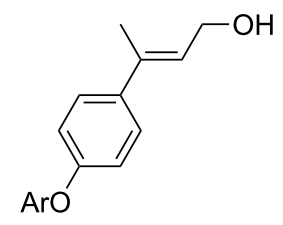

$\mathrm{Ar}=\mathrm{Ph}, 1-$ naphthyl, 2-naphthyl<smiles>[CH2]/C(C)=C\CO</smiles>

$$
\begin{gathered}
\mathrm{R}^{1}=\mathrm{R}^{2}=\mathrm{Me}, \mathrm{Et}, c-\mathrm{C}_{5} \mathrm{H}_{9}, \\
c-\mathrm{C}_{6} \mathrm{H}_{11} \\
\mathrm{R}^{1}=\mathrm{Me}, \mathrm{R}^{2}=\mathrm{Et}, \mathrm{OMe} ; \\
\mathrm{R}^{1}=\mathrm{H}, \mathrm{R}^{2}=\mathrm{Me}, \mathrm{Et}, \mathrm{Ph}
\end{gathered}
$$

1) $\mathrm{O}_{2}, h v, \mathrm{TPP}$ 2) $\mathrm{BF}_{3} \cdot \mathrm{Et}_{2} \mathrm{O}$ $\mathrm{CH}_{2} \mathrm{Cl}_{2}$<smiles>[R]C1([R])OOC(C(=C)C)C(C)O1</smiles>

i) $88-94$

ii) $63-78$

[371]

1) $\mathrm{O}_{2}, h v$,

methylene blue,

$\mathrm{MeCN}$,

$0{ }^{\circ} \mathrm{C}$,

4-6 h

2) $\mathrm{TsOH}, \mathrm{CH}_{2} \mathrm{Cl}_{2}$,

$\mathrm{rt}, 1 \mathrm{~h}$

1) $\mathrm{O}_{2}, h \mathrm{v}$,

methylene blue,

$\mathrm{MeCN},-10^{\circ} \mathrm{C}$

2) acid

3) $\mathrm{NaBH}_{4}, \mathrm{MeOH}$<smiles>[R]C1([R])OCC(C(=C)CCC(O)[Al])OO1</smiles>

i) $30-45$

ii) $50-74$

[372]

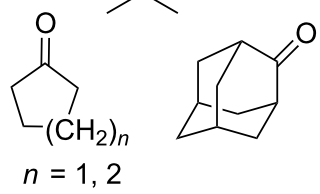<smiles>[R]C1([R])OCC(C(=C)CCC(O)C(=C)C)OO1</smiles>

The yield

was not<smiles>[R]C1([R])OCC(C(=C)CCCO)OO1</smiles>

determined
1) $\mathrm{O}_{2}, h \mathrm{v}$,

methylene blue,

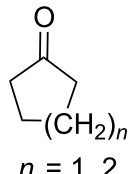

$\mathrm{MeCN}$,

$0{ }^{\circ} \mathrm{C}$,

4-6 h

2) $\mathrm{HCl}, 5^{\circ} \mathrm{C}, 18 \mathrm{~h}$<smiles>[R]C1([R])OCC(C(=C)[Al])OO1</smiles>

22-51

[374-379]
1) $\mathrm{O}_{2}, h v$,

methylene blue,

$\mathrm{MeCN}$,

$0{ }^{\circ} \mathrm{C}$,

2) $\mathrm{HCl}, \mathrm{rt}, 1 \mathrm{~h}$<smiles>[R]C1([R])COC(C(=C)c2ccc(Oc3ccccc3)cc2)CO1</smiles>

45-70

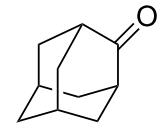

$n=1,2$<smiles>O=C1CCCC1</smiles><smiles>O=C1C2CC3CC(C2)CC1C3</smiles>

1) $\mathrm{O}_{2}, h \mathrm{v}$

methylene blue, $\mathrm{MeCN}$,

$0^{\circ} \mathrm{C}, 6 \mathrm{~h}$

2) $\mathrm{TsOH}, \mathrm{CH}_{2} \mathrm{Cl}_{2}$,

rt, $1 \mathrm{~h}$
$\overbrace{\mathrm{H}-\mathrm{O}}^{\mathrm{O}} \mathrm{X}_{\mathrm{R}^{2}}^{\mathrm{R}^{1}}$

i) 43

ii) $65-76$ 
Table 19: Examples of 1,2,4-trioxanes synthesized by the singlet oxygen ene reaction. (continued)<smiles>CC(C=O)=CCO</smiles><smiles>OC1C=C(Br)CCC1</smiles>
$\mathrm{Ar}=\mathrm{Ph}, 4-\mathrm{ClC}_{6} \mathrm{H}_{4}$, 4- $\mathrm{PhC}_{6} \mathrm{H}_{4}$<smiles>C/C(=C\CO)C1CC1</smiles><smiles>CC(=CCO)C1CCCCC1</smiles><smiles>[R]C(O)C=C(C)C</smiles>

$\mathrm{R}=\mathrm{Me}, \mathrm{Et}, \mathrm{iPr}, t-\mathrm{Bu}$ $n-\mathrm{Pr}, \mathrm{CH}_{2}-\mathrm{iPr}, c-\mathrm{Pr}$, cyclohexyl<smiles>O=C1CCCCC1</smiles><smiles>O=C1C2CC3CC(C2)CC1C3</smiles>
$n=1,2$<smiles>[R]C([R])=O</smiles>

$\mathrm{R}^{1}=\mathrm{Me}, \mathrm{R}^{2}=\mathrm{Me}$; $\mathrm{R}^{1}=\mathrm{Ph}, \mathrm{R}^{2}=\mathrm{H}$<smiles>O=C1CCCC1</smiles>

$\left(\mathrm{CH}_{2}\right)_{n}$<smiles>O=C1C2CC3CC(C2)CC1C3</smiles>
1) $\mathrm{O}_{2}, h \mathrm{v}$, methylene blue, $\mathrm{MeCN}$,

$0{ }^{\circ} \mathrm{C}, 18 \mathrm{~h}$

2) $\mathrm{HCl}, \mathrm{CH}_{2} \mathrm{Cl}_{2}$, $0{ }^{\circ} \mathrm{C}, 3-6 \mathrm{~h}$<smiles>[R]C1([R])OOC2C(Br)=CCCC2O1</smiles>

i) 37

ii) $46-59$

[381]

$0{ }^{\circ} \mathrm{C}, 6 \mathrm{~h}$

$\mathrm{sOH}, \mathrm{CH}_{2} \mathrm{Cl}_{2}$

$\mathrm{HO}\left(\mathrm{CH}_{2}\right)_{4} \mathrm{O}-\mathrm{O} \mathrm{R}^{2}$
i) $22-35$
i) 22-35

[382]

1) $\mathrm{O}_{2}, h \mathrm{v}$,

methylene blue $\mathrm{MeCN}$,

$0{ }^{\circ} \mathrm{C}, 6 \mathrm{~h}$

2) $\mathrm{TsOH}, \mathrm{CH}_{2} \mathrm{Cl}_{2}$,<smiles>O=C1CCCCC1</smiles>

rt, $2 \mathrm{~h}$<smiles>[R]C1([R])OCC(C(=C)C2CC2)OO1</smiles>

i) 50

ii) $31-75$

[383]

1) $\mathrm{O}_{2}, h \mathrm{v}$,

methylene blue, $\mathrm{MeCN}$,<smiles>O=C1CCCC1</smiles>
$\mathrm{R}^{1}=\mathrm{Ph}, \mathrm{R}^{2}=\mathrm{H}$

$0{ }^{\circ} \mathrm{C}, 6 \mathrm{~h}$;<smiles>O=C1C2CC3CC(C2)CC1C3</smiles>

2) $\mathrm{TsOH}, \mathrm{CH}_{2} \mathrm{Cl}_{2}$,

rt, $2 \mathrm{~h}$<smiles>[R]C1([R])OCC(C(=C)C2CCCCC2)OO1</smiles>

i) 35

ii) $57-83$

[383]

$n=1,2$<smiles>[R]C([R])=O</smiles>

$\mathrm{R}^{1}=\mathrm{Et}, \mathrm{R}^{2}=\mathrm{Me}$;

$\mathrm{R}^{1}=\mathrm{Et}, \mathrm{R}^{2}=\mathrm{H}$;

$\mathrm{R}^{1}=\beta$-naphthyl, $\mathrm{R}^{2}=\mathrm{H}$;

$\mathrm{R}^{1}=2-\mathrm{Fu}, \mathrm{R}^{2}=\mathrm{H}$;

$\mathrm{R}^{1}=\mathrm{Ph}, \mathrm{R}^{2}=\mathrm{H}$;

$\mathrm{R}^{1}=\mathrm{o}-\mathrm{CIPh}, \mathrm{R}^{2}=\mathrm{H}$; $\mathrm{HC}(\mathrm{OEt})_{3}$

1) $\mathrm{O}_{2}, h v$, TPP

2) $\mathrm{BF}_{3} \cdot \mathrm{Et}_{2} \mathrm{O}$,<smiles>O=C1CCCC1</smiles>

$\mathrm{Et}_{2} \mathrm{O}, 0^{\circ} \mathrm{C}$<smiles>[R]C1OC([R])([R])OOC1C(=C)C</smiles>

i) $54-97$

ii) $8-78$

[384-387]<smiles>O=C1CCC(=O)CC1</smiles><smiles>CC(C)(C)OC(=O)N1CCC(=O)CC1</smiles> 
Table 19: Examples of 1,2,4-trioxanes synthesized by the singlet oxygen ene reaction. (continued)<smiles>COC(C)=CCO</smiles><smiles>O=C1C2CC3CC(C2)CC1C3</smiles><smiles>O=C1CCC(=O)CC1</smiles><smiles>COC(=O)C(C)=CCO</smiles><smiles>C/C(=C/CO)C12CC3CC(CC(C3)C1)C2</smiles><smiles>[R]c1ccc(/C(C)=C/CO)cc1</smiles>

$\mathrm{R}=\mathrm{H}, \mathrm{OMe}, \mathrm{Me}$, $\mathrm{F}, \mathrm{Cl}, \mathrm{Br}$

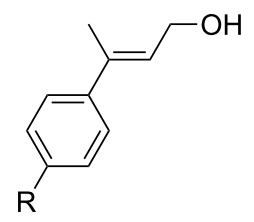

$\mathrm{R}=\mathrm{H}, \mathrm{OMe}, \mathrm{Me}$, $\mathrm{F}, \mathrm{Cl}, \mathrm{Br}$

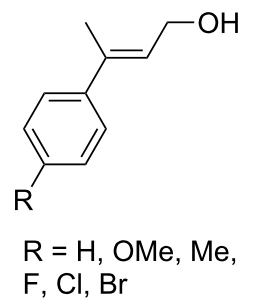

1) $\mathrm{O}_{2}, h v$, TTP, polystyrene 2) $\mathrm{BF}_{3} \cdot \mathrm{Et}_{2} \mathrm{O}$, $\mathrm{CH}_{2} \mathrm{Cl}_{2}$<smiles>[R]C1([R])OCC(C(=C)OC)OO1</smiles>
20-86 385,387 , 388]<smiles>C=C(C(C)=O)C1COOC2(CCC3(CC2)OCC(C(=C)C(C)=O)OO3)OC1</smiles>
20 [389]

PS-DVB-based 2) $\mathrm{BF}_{3} \cdot \mathrm{Et}_{2} \mathrm{O}$, $\mathrm{CH}_{2} \mathrm{Cl}_{2}$

1) $\mathrm{O}_{2}, h \mathrm{v}$,

methylene blue, $\mathrm{MeCN}, 0^{\circ} \mathrm{C}$,

4-5 h

2) $\mathrm{HCl}, \mathrm{CH}_{2} \mathrm{Cl}_{2}$, rt, $1 \mathrm{~h}$<smiles>[R]C1([R])OCC(C(=C)C23CC4CC(CC(C4)C2)C3)OO1</smiles>
38-54 [390]<smiles>[R]C1([R])OCC(C(=C)[Al])OO1</smiles>
23-69 [125-127] MeCN $0^{\circ}$ blue 2) $\mathrm{HCl}, \mathrm{MeCN}, \mathrm{rt}$, $3 \mathrm{~h}$

1) $\mathrm{O}_{2}, h v$, methylene blue, $\mathrm{MeCN}$,

$0{ }^{\circ} \mathrm{C}, 5 \mathrm{~h}$

2) $\mathrm{HCl}, \mathrm{MeCN}, \mathrm{rt}$, $3 \mathrm{~h}$<smiles>[R]C1([R])OCC(C(=C)[Al])OO1</smiles>

40-87

[125-127]<smiles>CC1CCC2C1CCC1[C@@H]2CCC2CC(=O)CC[C@@]21C</smiles>

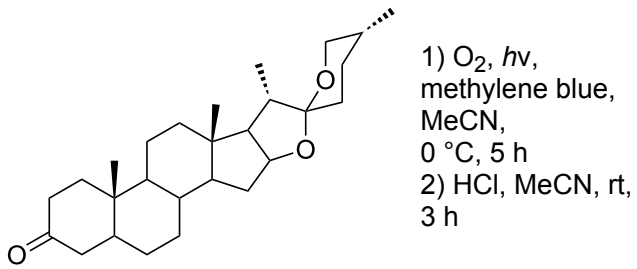


Table 19: Examples of 1,2,4-trioxanes synthesized by the singlet oxygen ene reaction. (continued)<smiles>[R]C(O)C=C(C)C</smiles>

$\mathrm{R}=n-\mathrm{Bu}, n-\mathrm{Pr}$ $\mathrm{iPr}$, iBu, allyl

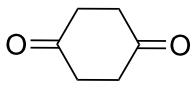<smiles>[R]C1(CCC(O)C(O)C(=C)C)OCCO1</smiles>

$\mathrm{R}=\mathrm{Me}, \mathrm{Et}$<smiles>[R][R]([R])([Y9])C(O)C(O)C=C(C)C</smiles>

$\mathrm{R}^{1} \mathrm{C}(\mathrm{OMe})_{3}$ $\mathrm{R}^{1}=\mathrm{Me}, \mathrm{Et}, n-\mathrm{Pr}, \mathrm{Ph}$

$\mathrm{R}=\mathrm{Me}, \mathrm{H}$<smiles>CC(C)=CC(O)C(C)(C)O</smiles>

$\mathrm{MeC}(\mathrm{OMe})_{3}$<smiles>CCOC(=O)CC(O)CC(O)C=C(C)C</smiles>

1) $\mathrm{O}_{2}, h v$, TTP or

TPP

PS-DVB-based

2) $\mathrm{BF}_{3} \cdot \mathrm{Et}_{2} \mathrm{O}$,

$\mathrm{CH}_{2} \mathrm{Cl}_{2}$<smiles>[R]C1OC2(CCC3(CC2)OOC(C(=C)C)C(C(=C)C)OO3)OC1[R]</smiles>

4-19

[389]

1) $\mathrm{O}_{2}, h \mathrm{v}$, TTP or

TPP

PS-DVB-based

2) $\mathrm{BF}_{3} \cdot \mathrm{Et}_{2} \mathrm{O}$,

$\mathrm{CH}_{2} \mathrm{Cl}_{2}$<smiles>[R]C12CCC(OO1)[C@H](C(=C)C)O2</smiles>

i) $84-91$

ii) $12-19$

[391]

1) $\mathrm{O}_{2}, h v, T P P$,

$\mathrm{CCl}_{4}, 10^{\circ} \mathrm{C}$

2) PPTS, $\mathrm{CH}_{2} \mathrm{Cl}_{2}$<smiles>[R]C12OCC([R])([R])C(OO1)C(C(=C)C)OO2</smiles>

i) 94-99

ii) $21-30$

[391]

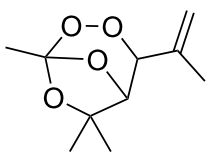

i) 83

$\mathrm{CCl}_{4}, 10^{\circ} \mathrm{C}$

2) PPTS, $\mathrm{CH}_{2} \mathrm{Cl}_{2}$

1) $\mathrm{O}_{2}, h v, T P P$,

$\mathrm{CCl}_{4}$, rt

2) $\mathrm{TsOH}, \mathrm{CH}_{2} \mathrm{Cl}_{2}$,

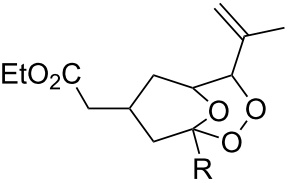

83

ii) $18-55$

aTPP is tetraphenylporphyrin; TTP is tetratolylporphyrin; PPTS is pyridinium para-toluenesulfonate.

A similar approach based on the co-oxidation of hydroxyalkenes 338 and thiols (TOCO-reaction, thiol-olefin co-oxygenation) was applied to the synthesis of sulfurcontaining 1,2,4-trioxanes 339 (Scheme 97).

$$
\begin{aligned}
& \mathrm{R}^{1} \mathrm{OH} \underset{\text { ii) ketone, } \mathrm{TsOH}, \mathrm{MeCN}}{\stackrel{\text { i) } \mathrm{AlBN}, \mathrm{ArSH}, \mathrm{O}_{2}, h v, 0^{\circ} \mathrm{C}}{\longrightarrow}} \mathrm{ArS} \underset{\mathrm{R}^{1}}{\stackrel{\mathrm{O}}{\mathrm{O}}} \stackrel{\mathrm{O}}{\mathrm{R}_{\mathrm{R}^{3}}^{\mathrm{R}^{2}}} \\
& 338 \\
& \begin{array}{l}
\mathrm{R}^{1}=\mathrm{Me}, \mathrm{Ph} \\
\mathrm{Ar}=\mathrm{Ph}, p-\mathrm{ClC}_{6} \mathrm{H}_{4}
\end{array}
\end{aligned}
$$

Scheme 97: Synthesis of sulfur-containing 1,2,4-trioxanes 339.

Azobisisobutyronitrile (AIBN) was used as the initiator of the radical reaction. In the second step (condensation), cyclopentanone, cyclohexanone, tert-butylcyclohexanone, 1,4-cyclohexanedione, cyclododecanone, and adamantanone were employed. 1,2,4-Trioxanes 339 were prepared in 25-68\% yields in two steps $[120,393]$.
The formation of peroxyketals 342a-g from vicinal hydroxyhydroperoxides 341 (oxidation products of unsaturated alcohols 340 ) in the presence of boron trifluoride is a convenient approach to the synthesis of the 1,2,4-trioxane ring (Scheme 98) [385].

The approach to the synthesis of 1,2,4-trioxanes proposed by Jefford and co-workers in 1993 [394] is based on the photooxidation of enol ethers or vinyl sulfides 343 with oxygen followed by the rearrangement of the resulting 1,2-dioxetanes in the presence of trialkylsilyl triflates. The resulting bicyclic compound 344 is structurally similar to artemisinin. Another version of this synthesis is based on the use of the ozone/triphenylphosphite in the oxidation step 1) (Scheme 99, Table 20).

This method was applied to the synthesis of tricyclic peroxide 346 (containing one carbon atom less in the mono-oxygen ring compared to structures 344) from the enol ether, 1-(2(methoxymethylene)cyclohexyl)-3-phenylpropan-2-one (345) (Scheme 100) [207]. 


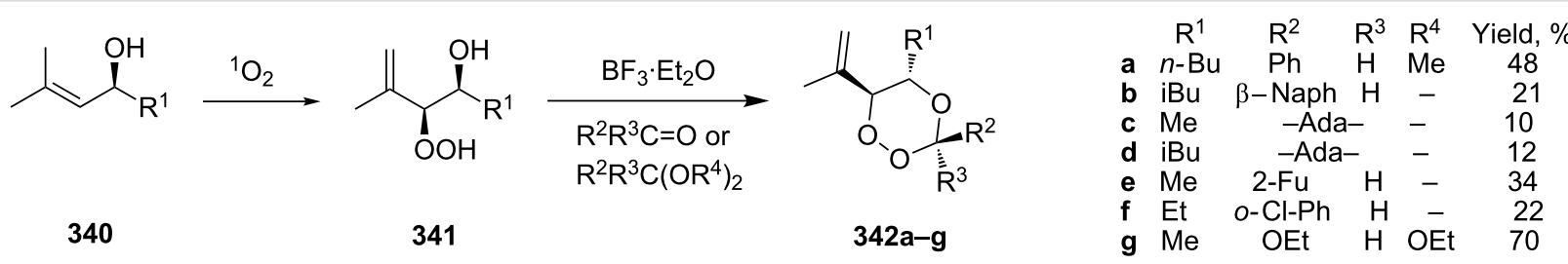

Scheme 98: $\mathrm{BF}_{3} \cdot \mathrm{Et}_{2} \mathrm{O}$-catalyzed synthesis of the 1,2,4-trioxanes $\mathbf{3 4 2 a - g}$.

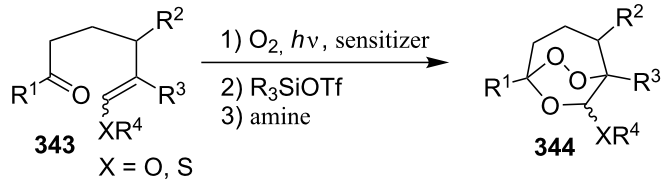

Scheme 99: Photooxidation of enol ethers or vinyl sulfides 343

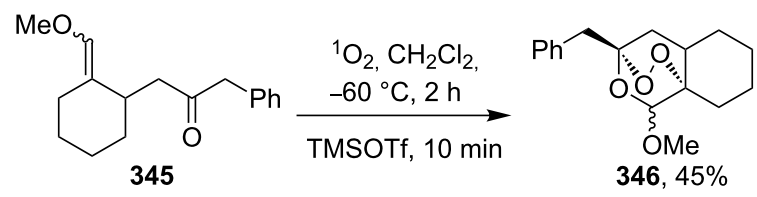

Scheme 100: Synthesis of tricyclic peroxide 346.

Table 20: Examples of 1,2,4-trioxanes synthesized by oxidation of enol ethers or vinyl sulfides.

Enol ether or vinyl sulfide $\mathbf{3 4 3}$ Reaction conditions Product $\mathbf{3 4 4}$

Yield, \% Reference<smiles>CC(=O)CCC1CCCCC1=C[GeH2][GeH2]</smiles>

1) $\mathrm{O}_{2}, h v$, methylene blue, $\mathrm{CH}_{2} \mathrm{Cl}_{2}$,

$-78^{\circ} \mathrm{C}$

2) TBDMSOTf, $\mathrm{CH}_{2} \mathrm{Cl}_{2}$,

$-78{ }^{\circ} \mathrm{C}$

3) $\mathrm{Et}_{3} \mathrm{~N}, \mathrm{CH}_{2} \mathrm{Cl}_{2},-78{ }^{\circ} \mathrm{C}$ to $-15{ }^{\circ} \mathrm{C}$<smiles>[R]O[SH](=O)(CC(=O)CCC1CCCCC1=CCOC)OC</smiles>

$\mathrm{R}=t-\mathrm{Bu}, \mathrm{Ph}$<smiles>CO/C=C1\CCCCC1CCC(=O)c1cccc(S(C)(=O)=O)c1</smiles><smiles>COC=C1CCCCC1CCC(=O)c1ccc(S(C)(=O)=O)cc1</smiles>

1) $\mathrm{O}_{3}$

1) $\mathrm{O}_{3},(\mathrm{PhO})_{3} \mathrm{P}, \mathrm{CH}_{2} \mathrm{Cl}_{2}$

$-78^{\circ} \mathrm{C}$

2) $\mathrm{Et}_{3} \mathrm{SiOTf}, \mathrm{CH}_{2} \mathrm{Cl}_{2},-78^{\circ} \mathrm{C}$

3) $\mathrm{Et}_{3} \mathrm{~N}, \mathrm{CH}_{2} \mathrm{Cl}_{2},-78{ }^{\circ} \mathrm{C}$ to $\mathrm{rt}$

1) $\mathrm{O}_{3},(\mathrm{PhO})_{3} \mathrm{P}, \mathrm{CH}_{2} \mathrm{Cl}_{2}$,

$-78{ }^{\circ} \mathrm{C}$

2) $\mathrm{Me}_{3} \mathrm{SiOTf}, \mathrm{CH}_{2} \mathrm{Cl}_{2},-78{ }^{\circ} \mathrm{C}$

3) $\mathrm{Et}_{3} \mathrm{~N}, \mathrm{CH}_{2} \mathrm{Cl}_{2},-78{ }^{\circ} \mathrm{C}$ to rt

MeS<smiles>C=Cc1ccc(C(=O)CCC2CCCCC2=COC)cc1</smiles>

3) $\mathrm{Et}_{3} \mathrm{~N}, \mathrm{CH}_{2} \mathrm{Cl}_{2},-78{ }^{\circ} \mathrm{C}$ to rt

1) Air, $h v$, methylene blue, $\mathrm{CH}_{2} \mathrm{Cl}_{2}$,

$-90{ }^{\circ} \mathrm{C}$

2) $\mathrm{Me}_{3} \mathrm{SiOTf}, \mathrm{CH}_{2} \mathrm{Cl}_{2}$,

$-90{ }^{\circ} \mathrm{C}, 1 \mathrm{~h}$

3) 1- ethylpiperidine, $\mathrm{CH}_{2} \mathrm{Cl}_{2}$,

$-78^{\circ} \mathrm{C}$ to $\mathrm{rt}$

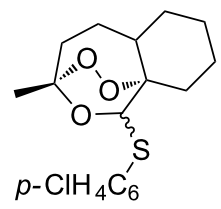

$47(12-\alpha)$

$47(12-\beta)$

[395]

$p-\mathrm{ClH}_{4} \mathrm{C}_{6}$<smiles>[R6]SC[C@]12CC[C@H]3CCCC[C@]3(OO1)[C@H](OC)O2</smiles>

30-38

[395]<smiles>CO[C@H]1O[C@]2(c3cccc(S(C)(=O)=O)c3)CC[C@@H]3CCCC[C@]31OO2</smiles>

7

[395]

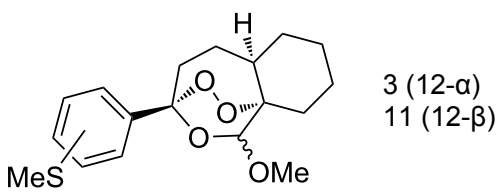

[395]

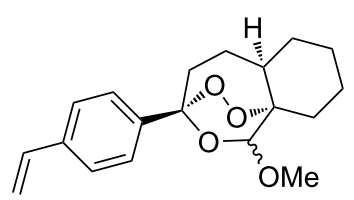

$36(12-\alpha)$

$15(12-\beta)$

[396]

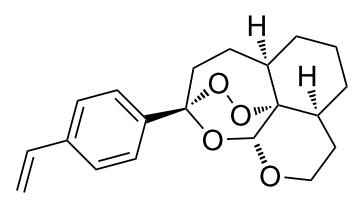

33

[397]

$-78^{\circ} \mathrm{C}, 1 \mathrm{~h}$

2) $\mathrm{Me}_{3} \mathrm{SiOTf}, \mathrm{CH}_{2} \mathrm{Cl}_{2}$,

$-78^{\circ} \mathrm{C}, 2 \mathrm{~h}$

3) 1-ethylpiperidine, $\mathrm{CH}_{2} \mathrm{Cl}_{2}$,

$-78^{\circ} \mathrm{C}$ to rt 


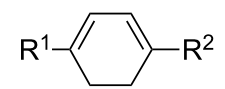

347a: $R^{1}=R^{2}=H$

347b: $R^{1}=M e, R^{2}=i P r$
$\underset{\mathrm{CH}_{2} \mathrm{Cl}_{2}, 5^{\circ} \mathrm{C}}{\stackrel{\mathrm{O}_{2}, h v, \mathrm{TPP}}{\longrightarrow}}$

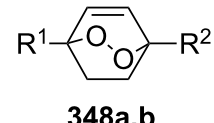

$348 \mathrm{a}, \mathrm{b}$

$80 \%$

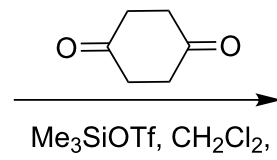

$-78^{\circ} \mathrm{C}$

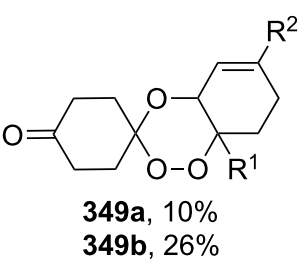

Scheme 101: Reaction of endoperoxides $348 \mathbf{a}, \mathbf{b}$ derived from cyclohexadienes $347 \mathbf{a}, \mathbf{b}$ with 1,4 -cyclohexanedione.

The reaction of endoperoxides $\mathbf{3 4 8 a}, \mathbf{b}$ derived from cyclohexadienes 347a,b with 1,4-cyclohexanedione produced trioxanes $\mathbf{3 4 9}$ a,b containing a keto group which is useful for further transformations (Scheme 101) [398].

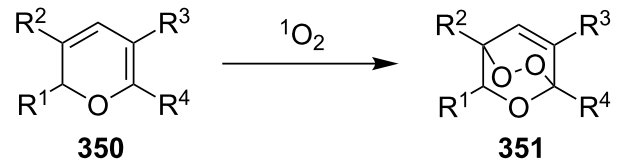

Scheme 102: [4 + 2]-Cycloaddition of singlet oxygen to $2 \mathrm{H}$-pyrans 350 .

Table 21: Examples of 1,2,4-trioxanes synthesized by oxidation of $2 \mathrm{H}$-pyrans

Pyran 350

Reaction conditions

1,2,4-Trioxane 351

Yield, \%

Reference<smiles>CC1(C)CCCC2(C)OC(/C=C/[Al])=CC=C12</smiles>

$\mathrm{O}_{2}, h v$, benzene

$\mathrm{Ar}=\mathrm{Ph}, p-\mathrm{MeC}_{6} \mathrm{H}_{4}$

$p-\mathrm{ClC}_{6} \mathrm{H}_{4}, p-\mathrm{BrC}_{6} \mathrm{H}_{4}$<smiles>CC1(C)C=CC2=C(CCCC2=O)O1</smiles>

Air, Rose Bengal, $h v$, THF, $-78^{\circ} \mathrm{C}$<smiles>CC1(C)C=CC2(/C=C/[Al])CC(C)(CCC1)OO2</smiles>

85-90 [399]

\subsection{Synthesis of 1,2,4-trioxanes by the} Isayama-Mukaiyama method

The Isayama-Mukaiyama peroxysilylation of unsaturated alcohols $\mathbf{3 5 2}$ is a new route to hydroxy silyl peroxides $\mathbf{3 5 3}$, whose condensation with ketones in an acidic medium affords 1,2,4trioxanes 354 (Scheme 103, Table 22).

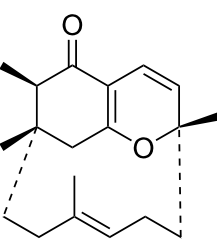

Air, Rose Bengal, $h v, \mathrm{CH}_{2} \mathrm{Cl}_{2}$, $-78^{\circ} \mathrm{C}$

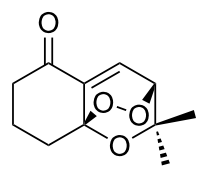

94

[400]

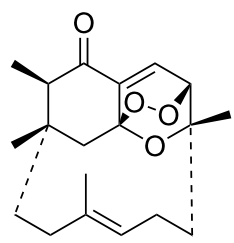

65

[401]

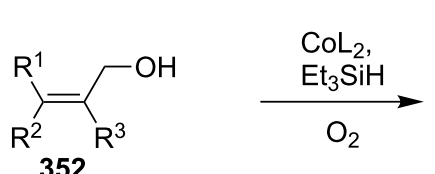

352<smiles>[R]C([R])C([R1])(CO)OOCC</smiles>

353

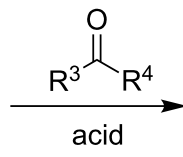<smiles>[R]C([R])C1([R1])COC([R])([R])OO1</smiles>

Scheme 103: Synthesis of 1,2,4-trioxanes 354 using peroxysilylation stage. 


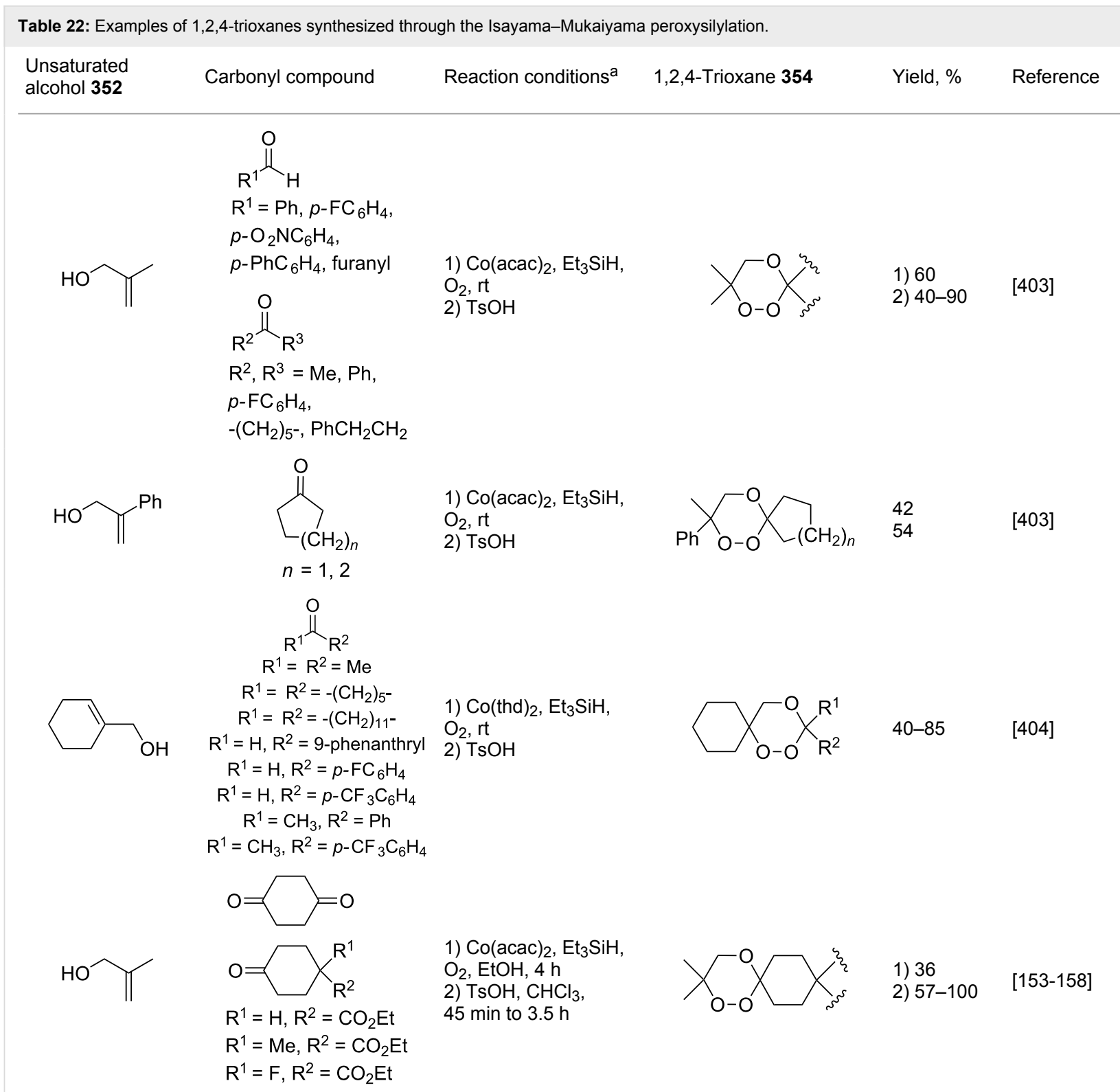

${ }^{\mathrm{a}}\left(\mathrm{Co}(\mathrm{III})(\text { thd })_{2}\right)$ is bis(2,2,6,6-tetramethyl-3,5-heptanedionato)cobalt (II).

\subsection{Use of epoxides as starting reagents in the syn-} thesis of 1,2,4-trioxanes

An important approach to the synthesis of 1,2,4-trioxanes 357 is based on the epoxide-ring opening in $\mathbf{3 5 5}$ with hydrogen peroxide in the presence of a catalyst followed by the condensation of the vicinal hydroxy hydroperoxides $\mathbf{3 5 6}$ with ketones (Scheme 104, Table 23). The drawbacks of this method are generally low yields of $\mathbf{3 5 6}$ in the step of the epoxide-ring opening and difficulties of their isolation from the reaction mixture.

The reaction of unsaturated ketones 358 with $\mathrm{H}_{2} \mathrm{O}_{2} / \mathrm{CF}_{3} \mathrm{COOH} /$ $\mathrm{H}_{2} \mathrm{SO}_{4}$ in dichloromethane produced 1,2,4-trioxanes 359 in $25-95 \%$ yields (Scheme 105). It is assumed that in the first step,

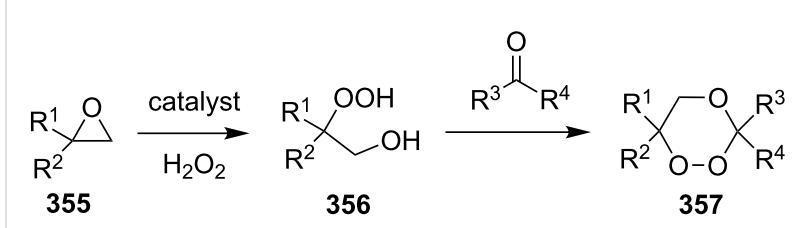

Scheme 104: Epoxide-ring opening in 355 with $\mathrm{H}_{2} \mathrm{O}_{2}$ followed by the condensation of hydroxy hydroperoxides 356 with ketones.

the hydroperoxidation of the keto group in $\mathbf{3 5 8}$ and the epoxidation of the double bond occur followed by the acid-induced intramolecular cyclization to form bicyclic compound 359 [408]. 


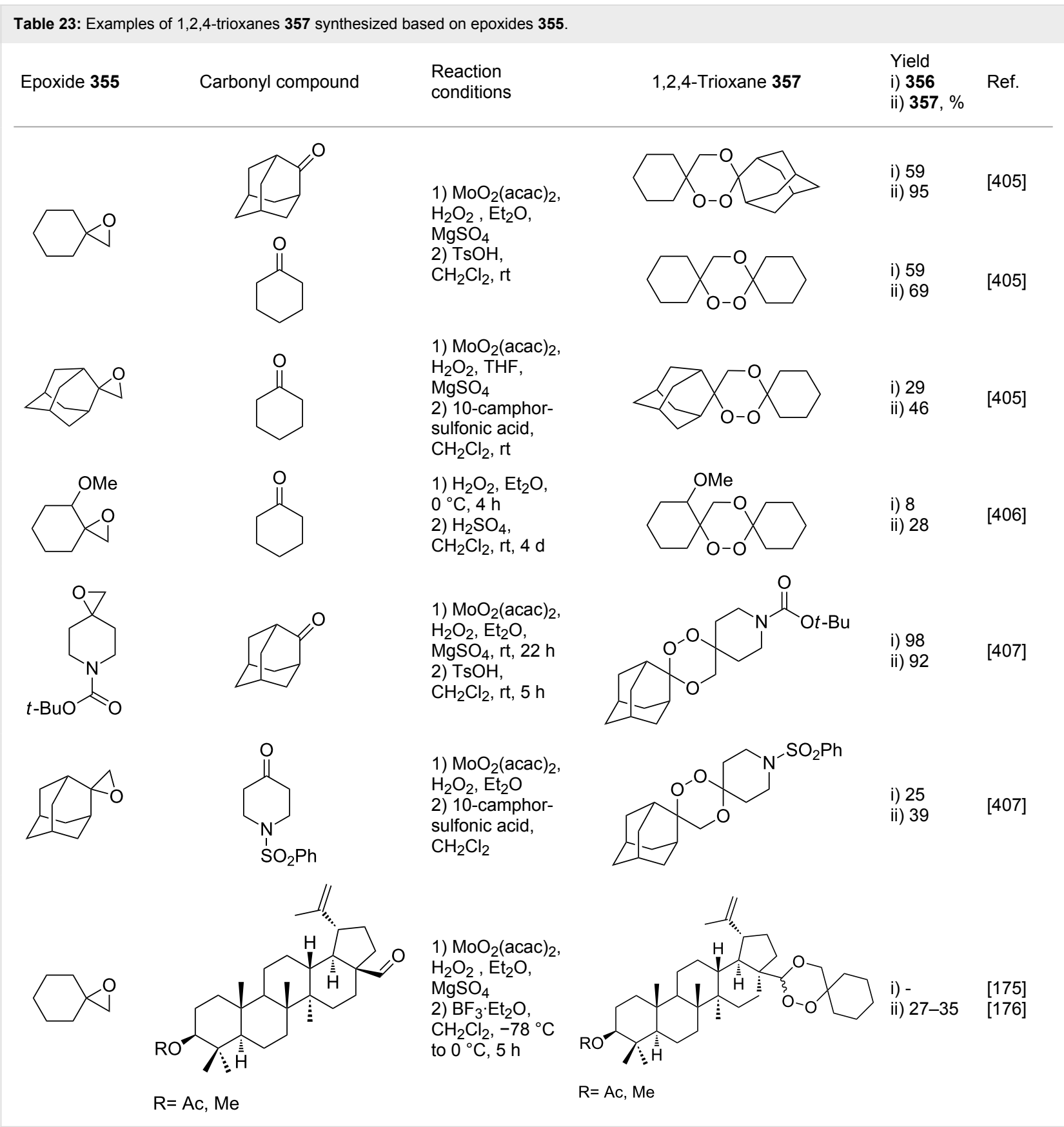

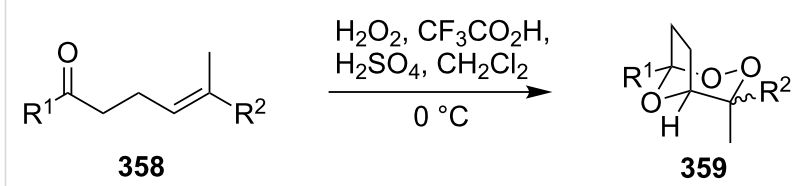

$\mathrm{R}^{1}=\mathrm{Me}, \mathrm{Et}, n-\mathrm{Pr}$, allylCH $\mathrm{CH}_{2}, \mathrm{PhCH}_{2} \mathrm{OCH}_{2} \mathrm{CH}_{2} \mathrm{CH}_{2}$ $\mathrm{R}^{2}=\mathrm{Me}, \mathrm{CH}_{2} \mathrm{OH}$

Scheme 105: Peroxidation of unsaturated ketones 358 with the $\mathrm{H}_{2} \mathrm{O}_{2}$ / $\mathrm{CF}_{3} \mathrm{COOH} / \mathrm{H}_{2} \mathrm{SO}_{4}$ system.

\subsection{Synthesis of 1,2,4-trioxanes by the Kobayashi} method

A convenient method for the synthesis of bicyclic trioxanes 362 was developed based on the hydroperoxidation of polyfunctional compounds $\mathbf{3 6 0}$ with the urea-hydrogen peroxide complex followed by the base-mediated intramolecular cyclization of 361 (Scheme 106). The yield of hydroperoxides 361 was 86-90\%. In the second step, the intramolecular cyclization was performed in the presence of a catalytic amount of diethylamine. The yields of trioxanes $\mathbf{3 6 2}$ are in the range of $10-35 \%$ $[409,410]$. 


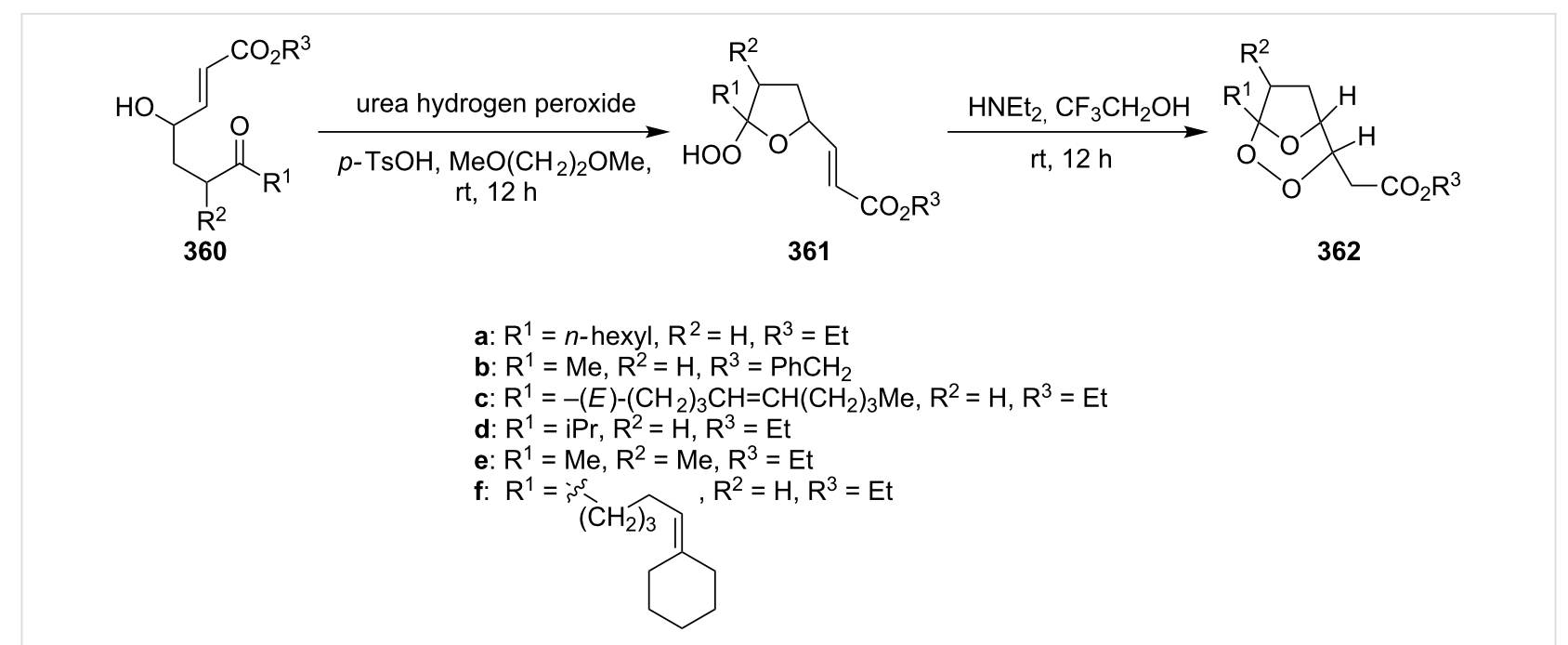

Scheme 106: Synthesis of 1,2,4-trioxanes 362 through $\mathrm{Et}_{2} \mathrm{NH}$-catalyzed intramolecular cyclization.

\subsection{Structural modifications, in which 1,2,4-trioxane ring remains intact}

The possibility of the reduction of the double bond in tricyclic peroxides 363 by hydrogen with the use of the mixed platinum-rhodium catalyst to form products, in which the $1,2,4$ trioxane moiety remains intact, was exemplified by the synthesis of peroxides 364 (Scheme 107) [411].

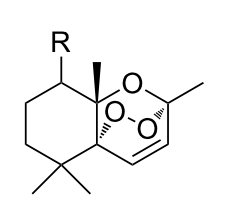

363

$\mathrm{R}=\mathrm{H}, \mathrm{OH}, \mathrm{OAC}$

Scheme 107: Reduction of the double bond in tricyclic peroxides 363

1,2,4-Trioxane esters 366 were synthesized in high yield from 1,2,4-trioxane ketones $\mathbf{3 6 5}$ by the Horner-Wadsworth-Emmons reaction in the presence of sodium hydride as the base (Scheme 108) [375]. Compounds 366 exhibit antimalarial activity comparable with that of artemisinin.
Peroxide dyad 369 consisting of 1,2,4-trioxane moieties of different types was synthesized by the esterification of artesunic acid with 2-((3S,6R)-1-methyl-6-(prop-1-en-2-yl)-7,8,9trioxabicyclo[3.3.1]nonan-3-yl)ethanol (368) (obtained by the reduction of ethyl 2-((3S,6R)-1-methyl-6-(prop-1-en-2-yl)7,8,9-trioxabicyclo[3.3.1]nonan-3-yl)acetate (367)) in the presence of $N, N^{\prime}$-dicyclohexylcarbodiimide (DCC) (Scheme 109) [392]. The particular structural feature of compound 369 is that it contains a natural peroxide moiety (artesunic acid) combined with the synthetic 1,2,4-trioxane moiety.

Trioxaquines are hybrid compounds containing the 1,2,4trioxane and aminoquinoline moieties. They attracted interest because of a dual mode of action on Plasmodium. One of these compounds, PA1103/SAR116242, was selected as a drug candidate. The final step of its synthesis involves the reductive amination of keto-containing 1,2,4-trioxane 370 with $N^{1}$-(7chloroquin-4-yl)cyclohexane-1,4-diamine (371) (Scheme 110) [86].

Trioxaferroquines, ferrocene-containing compounds, belong to a new type of hybrid molecules exhibiting high antimalarial activity. The last step of the synthesis of one of these com-

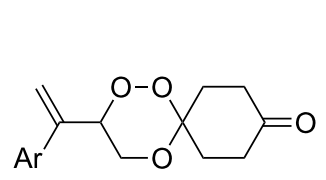

365

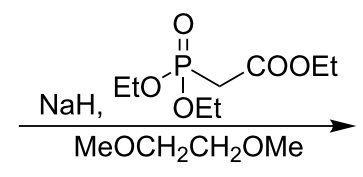

$$
\text { 366, 93\% }
$$

$\mathrm{Ar}=\mathrm{Ph}, 4-\mathrm{Ph}-\mathrm{C}_{6} \mathrm{H}_{4}$ 
<smiles>C=C(C)C1OOC2(C)CC(CC(=O)OCC)CC1C2</smiles>

367<smiles>C=C(C)[C@H]1OOC2(C)C[C@H](CCO)CC1O2</smiles>

$368,86 \%$

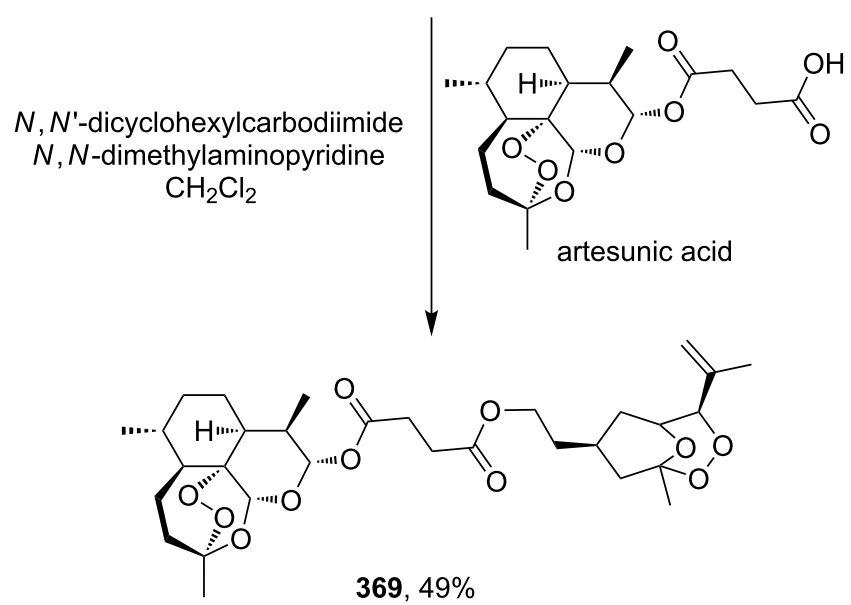

Scheme 109: Reduction of ester group by $\mathrm{LiBH}_{4}$ in the presence of 1,2,4-trioxane moiety.

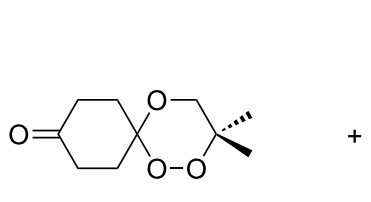

370

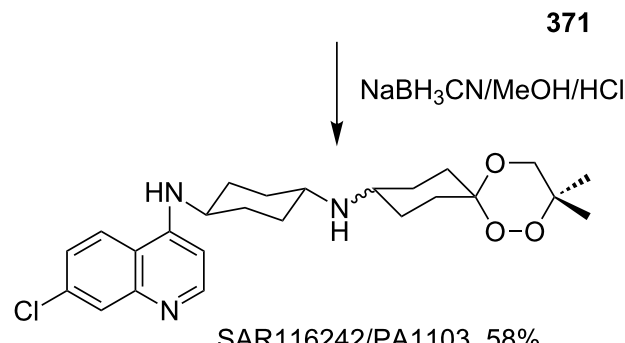

SAR116242/PA1103, 58\%

Scheme 110: Reductive amination of keto-containing 1,2,4-trioxane 370.

pounds (373) based on the reductive amination of ketone $\mathbf{3 7 0}$ with amine $\mathbf{3 7 2}$ is shown in Scheme 111. The unusual fact is that compound $\mathbf{3 7 3}$ bearing the peroxide bond and a Fe-containing moiety is stable [412].

\section{Synthesis fo 1,2,4,5-tetraoxanes}

The most widely used approaches to the synthesis of 1,2,4,5tetraoxanes are based on the reaction of ketones and aldehydes with hydrogen peroxide or gem-bishydroperoxides catalyzed by protic or aprotic acids, $\mathrm{MeReO}_{3}, \mathrm{Re}_{2} \mathrm{O}_{7}$, and iodine. These

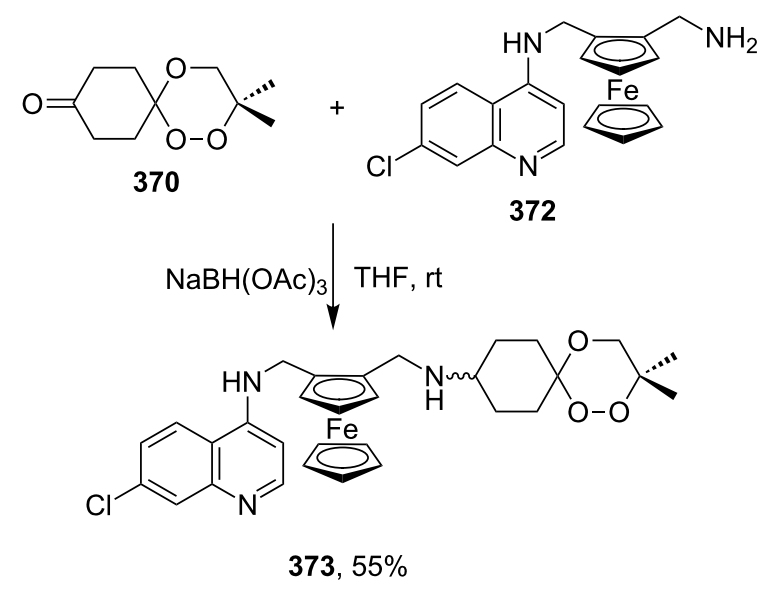

Scheme 111: Reductive amination of keto-containing 1,2,4-trioxane and a Fe-containing moiety.

methods were used for the synthesis of a wide range of symmetrical and unsymmetrical 1,2,4,5-tetraoxanes.

\subsection{Acid-catalyzed cyclocondensation of ketones and aldehydes with hydrogen peroxide}

This cyclocondensation is the simplest route to some symmetrical (containing identical substituents in positions 3 and 6) 1,2,4,5-tetraoxanes 375 starting from ketones 374 (Scheme 112, Table 24). The acid-catalyzed reactions of hydrogen peroxide with dialkyl ketones, cycloalkanones, and substituted mediumsize cycloalkanones produce symmetrical 1,2,4,5-tetraoxanes in 
moderate to high yields. The drawback of this method is the high sensitivity of the yields of the target peroxides to the structure of the starting carbonyl compounds.

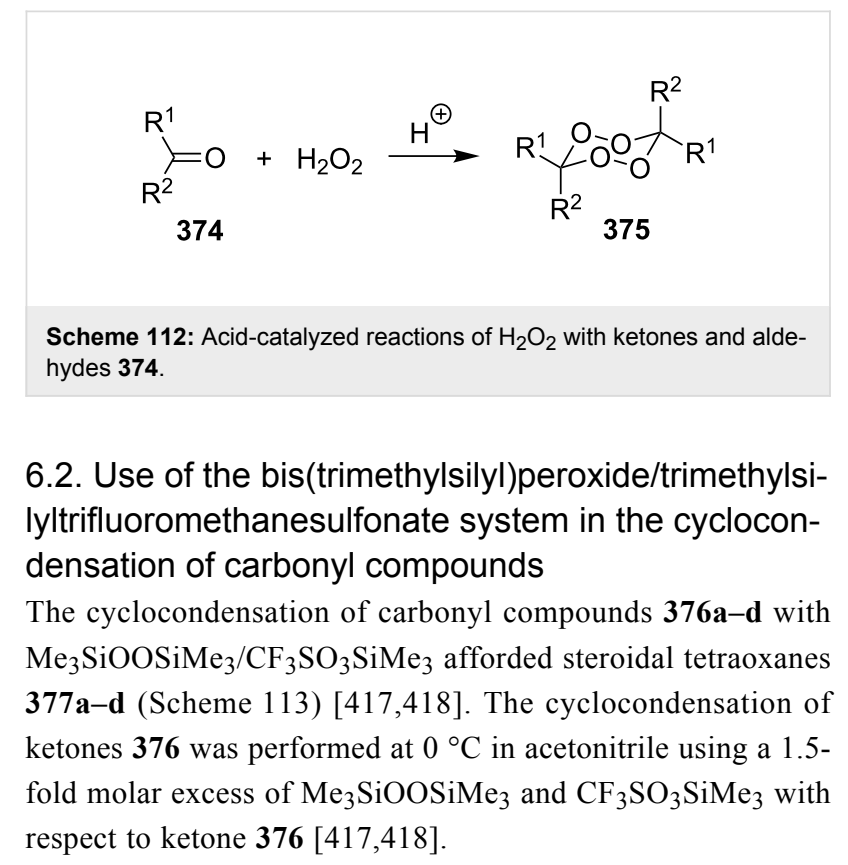

\section{3. $\mathrm{MeReO}_{3}$-catalyzed peroxidation of ketones}

1,1-Dihydroperoxy-4-methylcyclohexane (379) and symmetrical tetraoxane $\mathbf{3 8 0}$ were selectively synthesized in high yields from 4-methylcyclohexanone (378) with the use of the $30 \%$ $\mathrm{H}_{2} \mathrm{O}_{2} / \mathrm{MeReO}_{3}$ /fluorinated alcohol system (Scheme 114) [419].

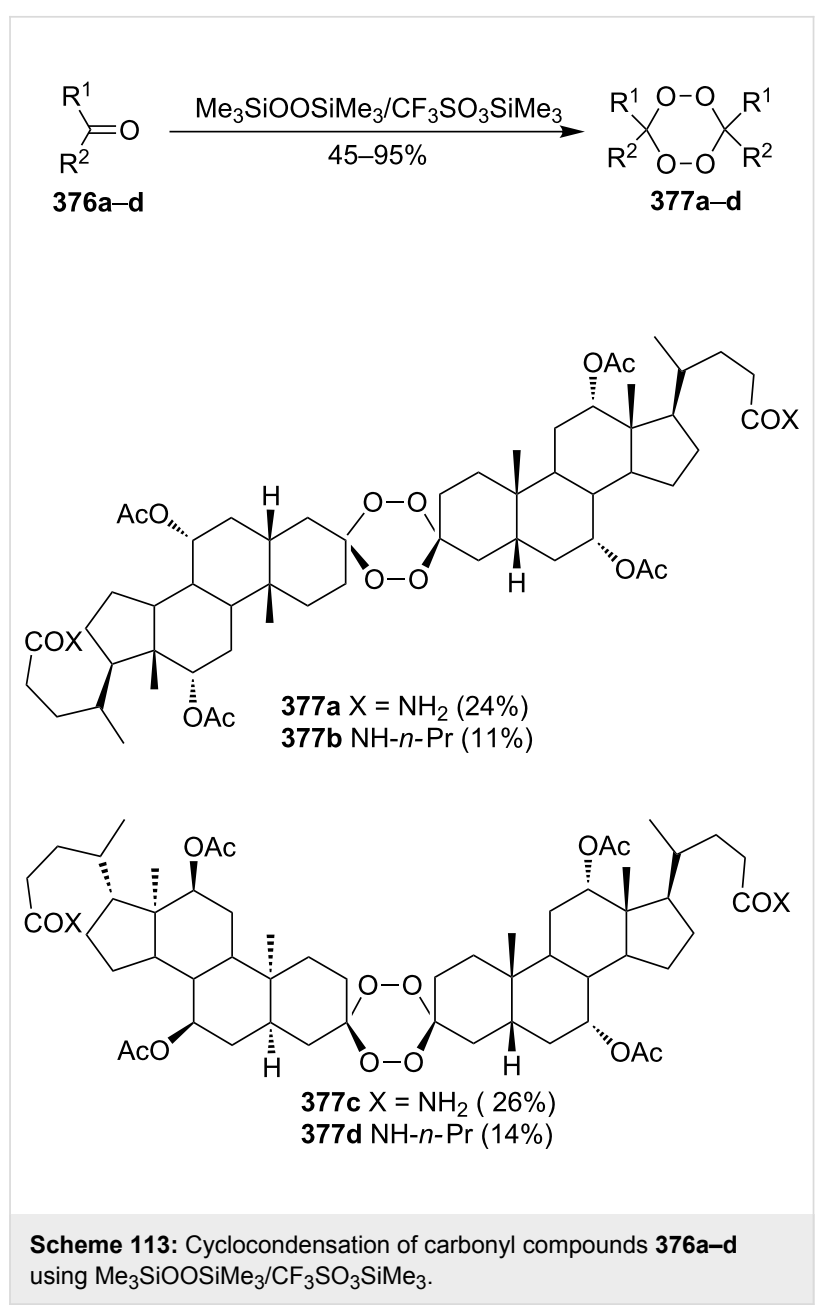

Table 24: Examples of symmetrical 1,2,4,5-tetraoxanes $\mathbf{3 7 5}$ synthesized by the acid-catalyzed cyclocondensation of ketones and aldehydes with $\mathrm{H}_{2} \mathrm{O}_{2}$.

\begin{tabular}{|c|}
\hline Tetraoxane $375 ; R^{1}, R^{2}$ \\
\hline$-\mathrm{CH}(\mathrm{Et})\left(\mathrm{CH}_{2}\right)_{4}-$ \\
\hline$-\mathrm{CH}(\mathrm{Pr})\left(\mathrm{CH}_{2}\right)_{4}-$ \\
\hline$-\mathrm{CH}_{2} \mathrm{CH}(\mathrm{Me})\left(\mathrm{CH}_{2}\right)_{3}-$ \\
\hline$-\mathrm{CH}(\mathrm{Me}) \mathrm{CH}(\mathrm{Me})\left(\mathrm{CH}_{2}\right)_{3}-$ \\
\hline$-\mathrm{CH}(\mathrm{Me}) \mathrm{CH}_{2} \mathrm{CH}(\mathrm{Me})\left(\mathrm{CH}_{2}\right)_{2}-$ \\
\hline$-\mathrm{CH}(\mathrm{Me})\left(\mathrm{CH}_{2}\right)_{2} \mathrm{CH}(\mathrm{Me}) \mathrm{CH}_{2}-$ \\
\hline$-\left(\mathrm{CH}_{2}\right)_{2} \mathrm{C}(\mathrm{Me})_{2}\left(\mathrm{CH}_{2}\right)_{2}-$ \\
\hline$-\mathrm{CH}(\mathrm{iPr})\left(\mathrm{CH}_{2}\right)_{2} \mathrm{CH}(\mathrm{Me}) \mathrm{CH}_{2}-$ \\
\hline$-\mathrm{CH}(\mathrm{Me})\left(\mathrm{CH}_{2}\right)_{2} \mathrm{CH}(\mathrm{iPr}) \mathrm{CH}_{2}-$ \\
\hline$-\mathrm{CH}(\mathrm{Me}) \mathrm{CH}_{2} \mathrm{C}(\mathrm{Me})_{2}\left(\mathrm{CH}_{2}\right)_{2}-$ \\
\hline$-\mathrm{CH}_{2} \mathrm{C}(\mathrm{Me})_{2} \mathrm{CH}_{2} \mathrm{C}(\mathrm{Me})_{2} \mathrm{CH}_{2}-$ \\
\hline$-\mathrm{C}(\mathrm{Me})_{2}\left(\mathrm{CH}_{2}\right)_{4}-$ \\
\hline$-\mathrm{CH}(\mathrm{Me})\left(\mathrm{CH}_{2}\right)_{3} \mathrm{CH}(\mathrm{Me})-$ \\
\hline$-\left(\mathrm{CH}_{2}\right)_{5}-$ \\
\hline$-\left(\mathrm{CH}_{2}\right)_{5}-$ \\
\hline $\mathrm{H},-\left(\mathrm{CH}_{2}\right)_{3} \mathrm{CHO}$ \\
\hline
\end{tabular}

Reaction conditions

Yield, \%

Reference

$\begin{array}{lll} & 24 \\ & 7 & \\ & 32 & \\ & 4 & \\ \mathrm{H}_{2} \mathrm{O}_{2}, \mathrm{MeCN}, \mathrm{H}_{2} \mathrm{SO}_{4},-20^{\circ} \mathrm{C}, 48 \mathrm{~h} & 20 \\ & 26 & \\ & 29 & \\ & 20 \\ & 26 \\ \mathrm{H}_{2} \mathrm{O}_{2}, \mathrm{EtOH} / \mathrm{H}_{2} \mathrm{O}, \mathrm{H}_{2} \mathrm{SO}_{4}, 0{ }^{\circ} \mathrm{C} & 34 \\ \mathrm{H}_{2} \mathrm{O}_{2},(\mathrm{CF} & \left.{ }_{2}\right)_{2} \mathrm{CHOH} & 68 \\ \mathrm{H}_{2} \mathrm{O}_{2}, \mathrm{EtOH} / \mathrm{H}_{2} \mathrm{O}, \mathrm{H}_{2} \mathrm{SO}_{4},-10^{\circ} \mathrm{C}, 1 \mathrm{~h} & 26 \\ & 18 \\ & 90 \\ & \approx 100 \\ & 80\end{array}$




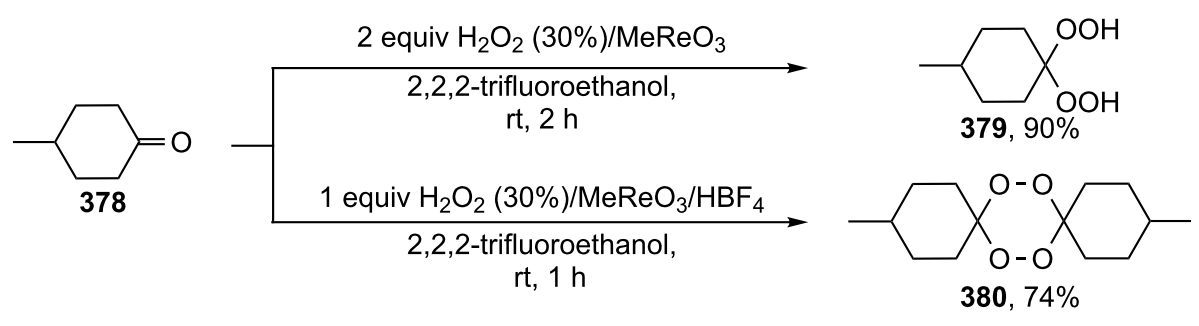

Scheme 114: Peroxidation of 4-methylcyclohexanone (378).

The use of fluorinated alcohols as the solvent results in an increase in the selectivity of the synthesis. Under similar conditions, symmetrical 3,6-diphenyl- and 3,6-di-( $n$-heptyl)-1,2,4,5tetraoxanes 382a,b were synthesized from benzaldehyde (381a) and $n$-octanal (381b), respectively (Scheme 115) [419].

Unsymmetrical tetraoxanes 383a-d were prepared from 4-methylcyclohexanone (378) by the reaction with ketones $\left(\mathrm{R}^{1} \mathrm{COR}^{2}\right.$ ) using of 1 equiv of $\mathrm{HBF}_{4}, 2$ equiv of $\mathrm{H}_{2} \mathrm{O}_{2}$, and $0.1 \mathrm{~mol} \% \mathrm{MeReO}_{3}$ in $\mathrm{CF}_{3} \mathrm{CH}_{2} \mathrm{OH}$ (TFE) at room temperature. The unsymmetrical tetraoxane, 3,3-dibutyl-6heptyl-1,2,4,5-tetraoxane (384), was synthesized from octanal (381b) with the use of $\mathrm{CH}_{3} \mathrm{CHOHCF}_{3}$ (HFIP) (Scheme 116) [419].
This method was applied to the synthesis of 3,3,6,6-tetraalkyl1,2,4,5-tetraoxanes 386a-c and 388a-i from cyclic 385a-c and acyclic ketones $\mathbf{3 8 7} \mathbf{a}-\mathbf{i}$ (Scheme 117) [420], as well as of dispiro-1,2,4,5-tetraoxanes 390a-c from 4-substituted cyclohexanones 389a-c (Scheme 118) [421].

The use of the $30 \% \mathrm{H}_{2} \mathrm{O}_{2} / \mathrm{MeReO}_{3}$ (MTO)/fluorinated alcohol system enabled the synthesis of symmetrical compounds 392 from aldehydes 391 and unsymmetrical tetraoxanes 393 containing aryl (peroxide-destabilizing) substituents from aldehydes 391 (and cycloalkanones) (Scheme 119) [422].

Unsymmmetrical 1,2,4,5-tetraoxanes containing adamantane (395a-i) and cyclodecane moieties (396a-d) exhibiting high

$$
\begin{aligned}
& \left.\mathrm{R}-\mathrm{CHO} \stackrel{1 \text { equiv } \mathrm{H}_{2} \mathrm{O}_{2}(30 \%) / \mathrm{MeReO}_{3} / \mathrm{HBF}_{4}}{\longrightarrow} \mathrm{R}-\mathrm{O}_{\mathrm{O}}^{\mathrm{O}-\mathrm{O}}\right\rangle_{\mathrm{R}} \\
& \text { 381a: } R=P h \quad \text { 2,2,2-trifluoroethanol, } \quad \text { 382a, } 77 \% \\
& \mathrm{rt}, 1 \mathrm{~h} \\
& \text { 381b: } \mathrm{R}=\mathrm{C}_{7} \mathrm{H}_{15} \quad \text { 1,1,1,3,3,3-hexafluoro-2-propanol, } \quad 3 \mathbf{3 8 2 b}, 86 \% \\
& \text { rt, } 1 \mathrm{~h}
\end{aligned}
$$

Scheme 115: Synthesis of symmetrical tetraoxanes $382 a, b$ from aldehydes $381 a, b$.

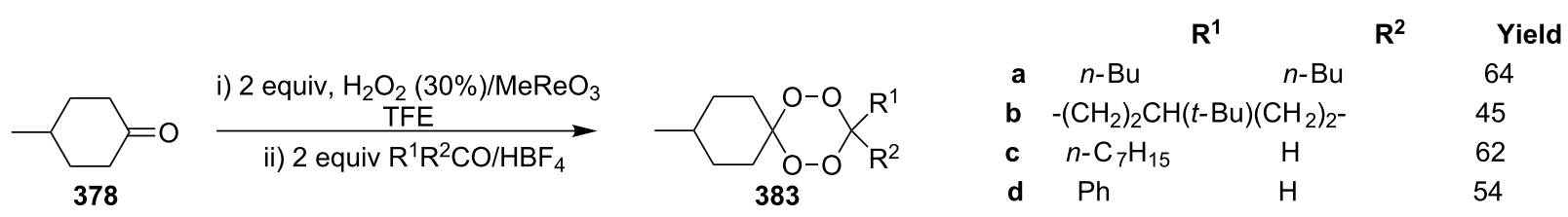

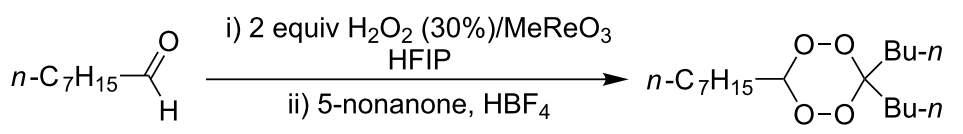

$381 b$

384, $51 \%$ 

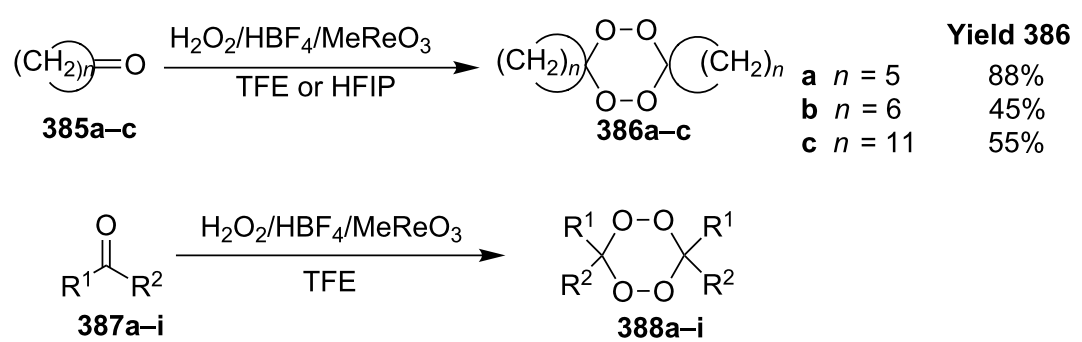

\begin{tabular}{|c|c|c|c|}
\hline \multicolumn{2}{|c|}{ Yield 388} & \multicolumn{2}{|c|}{ Yield 388} \\
\hline $\mathbf{a} \mathrm{R}^{1}=\mathrm{Et}, \mathrm{R}^{2}=\mathrm{Et}$ & $57 \%$ & f $\mathrm{R}^{1}=\mathrm{Et}, \mathrm{R}^{2}=n-\mathrm{C}_{5} \mathrm{H}_{11}$ & $59 \%$ \\
\hline b $\mathrm{R}^{1}=n-\operatorname{Pr}, \mathrm{R}^{2}=n-\operatorname{Pr}$ & $45 \%$ & $\mathbf{g} \mathrm{R}^{1}=\mathrm{Et}, \mathrm{R}^{2}=n-\mathrm{C}_{6} \mathrm{H}_{13}$ & $55 \%$ \\
\hline $\mathrm{c}^{1}=n-\mathrm{Bu}, \mathrm{R}^{2}=n-\mathrm{Bu}$ & $44 \%$ & h $\mathrm{R}^{1}=\mathrm{Et}, \mathrm{R}^{2}=n-\mathrm{C}_{7} \mathrm{H}_{15}$ & $57 \%$ \\
\hline $\mathbf{d} \mathrm{R}^{1}=\mathrm{Et}, \mathrm{R}^{2}=n-\mathrm{Pr}$ & $56 \%$ & i $\mathrm{R}^{1}=\mathrm{Me}, \mathrm{R}^{2}=n-\mathrm{C}_{7} \mathrm{H}_{15}$ & $72 \%$ \\
\hline e $\mathrm{R}^{1}=\mathrm{Et}, \mathrm{R}^{2}=n=\mathrm{Bu}$ & $55 \%$ & & \\
\hline
\end{tabular}

Scheme 117: Synthesis of symmetrical tetraoxanes using of $\mathrm{MeReO}_{3}$.

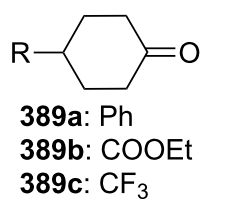
$\mathrm{MeReO}_{3} / \mathrm{H}_{2} \mathrm{O}_{2} / \mathrm{HBF}_{4} / \mathrm{Et}_{2} \mathrm{O}$
HFIP,
$\mathrm{rt}, 5 \mathrm{~min}$

389c: $\mathrm{CF}_{3}$

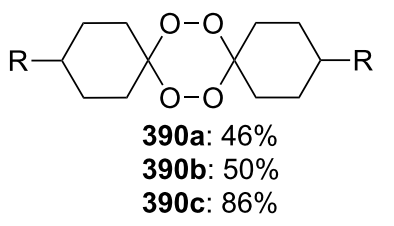

390c: $86 \%$

Scheme 118: Synthesis of symmetrical tetraoxanes using of $\mathrm{MeReO}_{3}$.

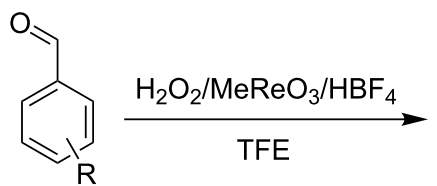

391

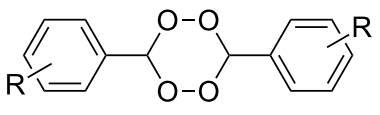

392

a $\mathrm{R}=p-\mathrm{CH}_{3} ; \quad$ b $\mathrm{R}=m-\mathrm{CH}_{3}$

c $\mathrm{R}=0-\mathrm{CH}_{3} ;$ d $\mathrm{R}=p-\mathrm{Br}$

e $\mathrm{R}=m-\mathrm{Br} ; \quad$ f $\mathrm{R}=0-\mathrm{Br}$

g $\mathrm{R}=p-\mathrm{Cl} ; \quad$ h $\mathrm{R}=m-\mathrm{Cl}$

i $\mathrm{R}=0-\mathrm{Cl} ; \quad$ j $\mathrm{R}=p-\mathrm{F}$

k $\mathrm{R}=p-\mathrm{CF}_{3} ; \quad$ I $\mathrm{R}=m-\mathrm{CF}_{3}$

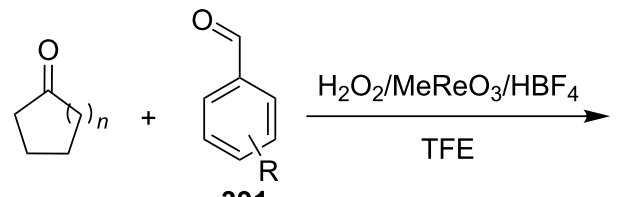

391

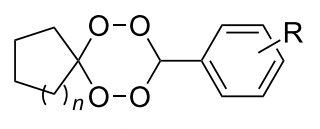

393
a $\mathrm{R}=\mathrm{H}, n=1$;
b $\mathrm{R}=p-\mathrm{Br}, n=$ '
c $\mathrm{R}=p-\mathrm{Cl}, n=1 ; \quad$ d $\mathrm{R}=\mathrm{H}, n=2$
e $\mathrm{R}=p-\mathrm{Cl}, n=2 ;$ f $\mathrm{R}=m-\mathrm{Cl}, n=$
g $\mathrm{R}=0-\mathrm{Cl}, n=2 ; \quad$ h $\mathrm{R}=p-\mathrm{Br}, n=$
i $\mathrm{R}=\mathrm{H}, n=3$;
j $\mathrm{R}=p-\mathrm{Br}, n=$
k $\mathrm{R}=p-\mathrm{Cl}, n=3$ 


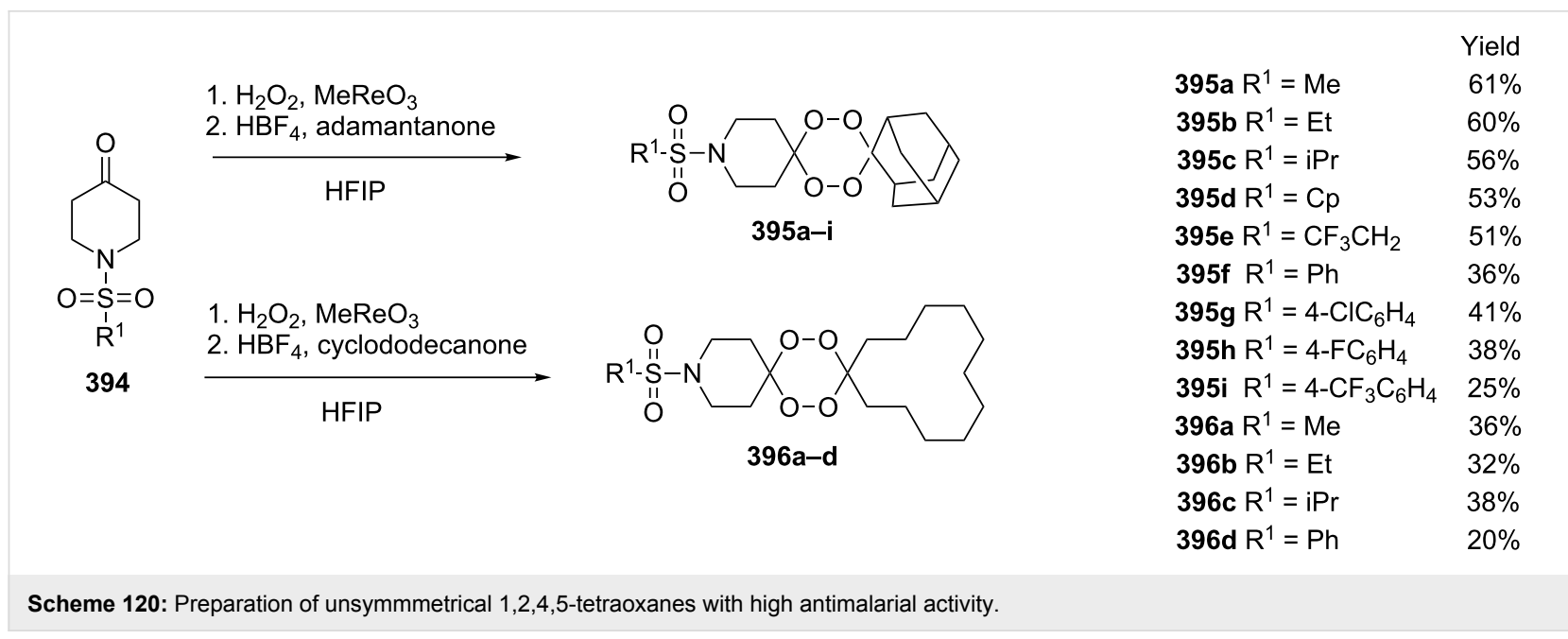

antimalarial activity (Scheme 120) were prepared from sulfonylpiperidones 394 [138].

\section{4. $\mathrm{Re}_{2} \mathrm{O}_{7}$-Catalyzed cyclocondensation of gem- bishydroperoxides with ketones}

$\mathrm{Re}_{2} \mathrm{O}_{7}$ is an efficient catalyst for the addition of hydroperoxide groups to ketones and aldehydes. Due to these properties, $\mathrm{Re}_{2} \mathrm{O}_{7}$ can be used in the one-pot synthesis of unsymmetrical 1,2,4,5-tetraoxanes 398 from ketones $\mathbf{3 9 7}$ in good yields (Scheme 121, Table 25) [423].

\subsection{Protic acid-catalyzed cyclocondensation of gem-bishydroperoxides with ketones}

Unsymmetrical steroidal tetraoxanes $\mathbf{4 0 1}$ were synthesized by the hydroperoxidation of methyl 3-oxo-7 $\alpha, 12 \alpha$-diacetoxy-5 $\beta$ cholan-24-oate (399) in the presence of $\mathrm{HCl}$ followed by the

$$
\begin{aligned}
& \stackrel{\mathrm{O}}{\stackrel{\text { 1) } \mathrm{Re}_{2} \mathrm{O}_{7}(3 \%), 50 \% \mathrm{H}_{2} \mathrm{O}_{2}, \mathrm{CH}_{3} \mathrm{CN}}{\mathrm{R}^{1}}} \stackrel{\text { 2) } \left.\mathrm{R}^{3} \mathrm{C}(\mathrm{O}) \mathrm{R}^{4} \text { (ketone } \mathrm{B}\right), \mathrm{Re}_{2} \mathrm{O}_{7}(2 \%),}{\longrightarrow} \\
& \mathrm{CH}_{2} \mathrm{Cl}_{2} \text { or TFE } \\
& { }_{\mathrm{R}^{1}}^{\mathrm{R}_{\mathrm{R}}^{3}}
\end{aligned}
$$

Scheme 121: $\mathrm{Re}_{2} \mathrm{O}_{7}$-Catalyzed synthesis of tetraoxanes 398 .

condensation of bishydroperoxide $\mathbf{4 0 0}$ with the corresponding ketone in the presence of $\mathrm{H}_{2} \mathrm{SO}_{4}$ (Scheme 122) $[128,132,141,142]$.

\begin{tabular}{|c|c|c|c|c|}
\hline Ketone A, 397 & Ketone B & Reaction conditions & Tetraoxane 398 & Yield, \% \\
\hline$t-\mathrm{Bu}$ & & $\begin{array}{l}\text { 1) } \mathrm{H}_{2} \mathrm{O}_{2} \text { ( } 2 \text { equiv), } 0.5 \mathrm{~h} \text {, } \\
0{ }^{\circ} \mathrm{C} \\
\text { 2) Ketone } \mathrm{B} \text { ( } 2 \text { equiv), } \\
\mathrm{CH}_{2} \mathrm{Cl}_{2}, 1 \mathrm{~h}, \mathrm{rt}\end{array}$ & & 67 \\
\hline & & $\begin{array}{l}\text { 1) } \mathrm{H}_{2} \mathrm{O}_{2} \text { (4 equiv), } 0.5 \mathrm{~h} \text {, } \\
\mathrm{rt} \\
\text { 2) Ketone } \mathrm{B} \text { (4 equiv), } \\
\text { 2,2,2-trifluoroethanol, } \\
\mathrm{Re}_{2} \mathrm{O}_{7}, 0.5 \mathrm{~h}, \mathrm{rt}\end{array}$ & & 69 \\
\hline & & $\begin{array}{l}\text { 1) } \mathrm{H}_{2} \mathrm{O}_{2} \text { (4 equiv), } 6 \mathrm{~h} \text {, rt } \\
\text { 2) Ketone } \mathrm{B} \text { (4 equiv), } \\
\text { 2,2,2-trifluoroethanol, } \\
\mathrm{Re}_{2} \mathrm{O}_{7}, 2 \mathrm{~h}, \mathrm{rt}\end{array}$ & & 49 \\
\hline
\end{tabular}

Structurally more simple ketones, for example, acetone, are also involved in the cyclocondensation with bishydroperoxide $\mathbf{4 0 0}$ [141]. 
<smiles>CC(=O)OCCC(C)C1CCC2C3C(OC(C)=O)CC4CC(=O)CC[C@]4(C)C3C[C@H](OC(C)=O)C12C</smiles>

399 i: $\mathrm{H}_{2} \mathrm{O}_{2}, \mathrm{HCl}$, $\mathrm{CH}_{2} \mathrm{Cl}_{2}, \mathrm{MeCN}$

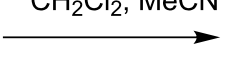

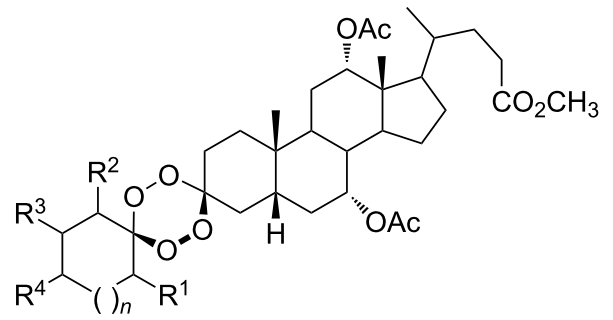

401a-m<smiles>CC(=O)OCCC(C)C1CCC2C3C(OC(C)=O)C[C@H]4CC(O)(O)CC[C@]4(C)C3CC(O)C12C</smiles>

ii: ketone, $\mathrm{H}_{2} \mathrm{SO}_{4}, \mathrm{CH}_{2} \mathrm{Cl}_{2}$ $\mathrm{MeCN}, 0^{\circ} \mathrm{C}, 15 \mathrm{~min}$

401a: $\mathrm{R}^{1}=\mathrm{R}^{2}=\mathrm{R}^{3}=\mathrm{R}^{4}=\mathrm{H} ; n=0 ; 26 \%$

401b: $\mathrm{R}^{1}=\mathrm{R}^{2}=\mathrm{R}^{3}=\mathrm{R}^{4}=\mathrm{H} ; n=1 ; 31 \%$

401c: $\mathrm{R}^{1}=\mathrm{R}^{2}=\mathrm{R}^{3}=\mathrm{R}^{4}=\mathrm{H} ; n=3 ; 34 \%$

$n=1$

401d: $\mathrm{R}^{1}=\mathrm{CH}_{3}, \mathrm{R}^{2}=\mathrm{R}^{3}=\mathrm{R}^{4}=\mathrm{H} ; 38 \%$

401e: $R^{1}=R^{2}=C_{3}, R^{3}=H ; 25 \%$

401f: $R^{1}=i P r, R^{3}=C_{3}, R^{2}=R^{4}=H ; 19 \%$

401g: $\mathrm{R}^{4}=(4 " R) \mathrm{CH}_{3}, \mathrm{R}^{1}=\mathrm{R}^{2}=\mathrm{R}^{3}=\mathrm{H} ; 12 \%$

401h: $R^{4}=(4 " S) \mathrm{CH}_{3}, \mathrm{R}^{1}=\mathrm{R}^{2}=\mathrm{R}^{3}=\mathrm{H} ; 12 \%$

401i: $R^{4}=(4 " R$ or $S) \mathrm{CH}_{3} \mathrm{CH}_{2}, \mathrm{R}^{1}=\mathrm{R}^{2}=\mathrm{R}^{3}=\mathrm{H} ; 15 \%$

401j: $\mathrm{R}^{4}=\left(4 " S\right.$ or $R$ ) $\mathrm{CH}_{3} \mathrm{CH}_{2}, \mathrm{R}^{1}=\mathrm{R}^{2}=\mathrm{R}^{3}=\mathrm{H} ; 15 \%$

401k: $\mathrm{R}^{4}=(4 " R$ or $S) t-\mathrm{Bu}, \mathrm{R}^{1}=\mathrm{R}^{2}=\mathrm{R}^{3}=\mathrm{H} ; 11 \%$

401I: $\mathrm{R}^{4}=\left(4\right.$ " $S$ or $R$ ) $t-\mathrm{Bu}, \mathrm{R}^{1}=\mathrm{R}^{2}=\mathrm{R}^{3}=\mathrm{H} ; 28 \%$

401m: $R^{1}=R^{2}=R^{3}=H, R^{4}=$ COOMe; $33 \%$

Scheme 122: $\mathrm{H}_{2} \mathrm{SO}_{4}$-Catalyzed synthesis of steroidal tetraoxanes 401 .

The synthesis of keto-containing tetraoxane $\mathbf{4 0 3}$ was also performed in two steps [144]. Thus the intermediate 1,1-dihydroperoxycyclohexane $\mathbf{4 0 2}$ was prepared from cyclohexanone in a neutral medium, and its condensation with 1,4-cyclohexanedione was carried out in the presence of $\mathrm{HBF}_{4}$ (Scheme 123).

\subsection{Cyclocondensation of bishydroperoxides with acetals and enol ethers}

The method for the synthesis of 1,2,4,5-tetraoxanes $\mathbf{4 0 7}$ and $\mathbf{4 0 8}$ is based on the boron trifluoride etherate-catalyzed reaction of gem-bishydroperoxides $\mathbf{4 0 4}$ with enol ethers $\mathbf{4 0 5}$ and acetals
406 under mild conditions. More than two dozens of tetraoxanes were synthesized in yields from 45 to $95 \%$ according to this method (Scheme 124). The advantage of this method is the use of readily available starting compounds, such as acetals, enol ethers, and boron trifluoride etherate [424,425].

The bishydroperoxidation of 1,3-dioxolane 409 was carried out in the presence of $\mathrm{H}_{2} \mathrm{WO}_{4}$. The following $\mathrm{HBF}_{4}$-catalyzed condensation of bishydroperoxide $\mathbf{4 1 0}$ with ketones gave 1,2,4,5tetraoxanes 411a-c containing the ester group (Scheme 125) [144].

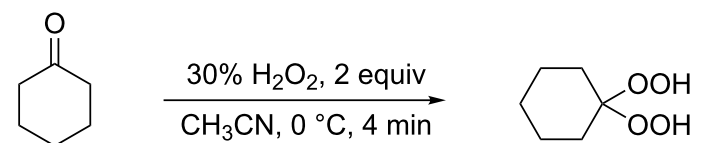

402, 76\%
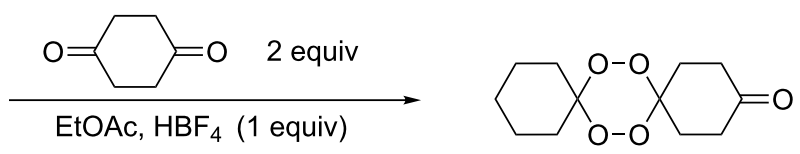

403, $38 \%$ 


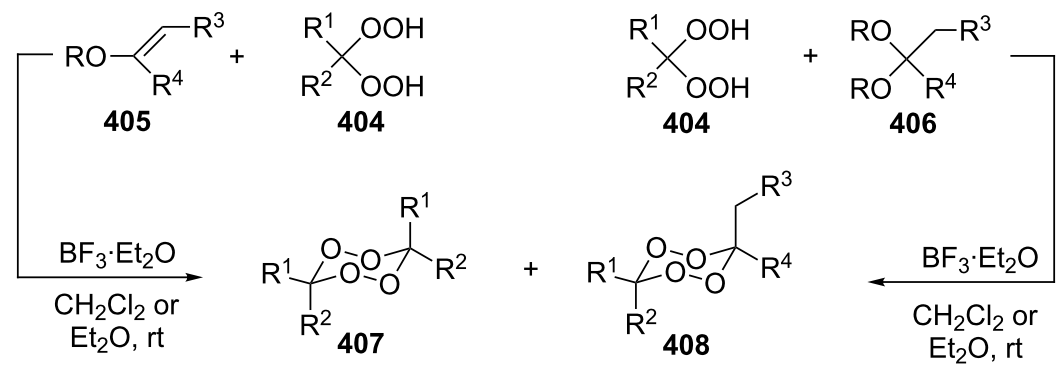

Scheme 124: $\mathrm{BF}_{3} \cdot \mathrm{Et}_{2} \mathrm{O}$-Catalyzed reaction of $g e m$-bishydroperoxides 404 with enol ethers 405 and acetals 406 .

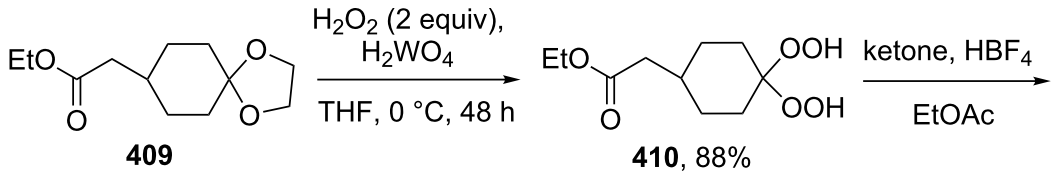

411a $\mathrm{R}^{1}=\mathrm{R}^{2}=-\left(\mathrm{CH}_{2}\right)_{5^{-}}, 75 \%$

411b $\mathrm{R}^{1}=\mathrm{R}^{2}=-\left(\mathrm{CH}_{2}\right)_{11}-, 66 \%$

411c $R^{1}=R^{2}=$ adamantylidene, $87 \%$

Scheme 125: $\mathrm{HBF}_{4}$-Catalyzed cyclocondensation of bishydroperoxide 410 with ketones.

6.7. lodine-catalyzed one-pot synthesis of symmetrical and unsymmetrical tetraoxanes

The reaction of substituted benzaldehyde $\mathbf{4 1 2}$ with hydrogen peroxide in the presence of the Lewis acid $\mathrm{I}_{2}$ produced geminal bishydroperoxide, whose condensation with the starting or another substituted benzaldehyde gave tetraoxane $\mathbf{4 1 3}$ (Scheme 126, Table 26) [426,427].

The iodine-catalyzed one-pot synthesis of symmetrical and unsymmetrical tetraoxanes from substituted benzaldehydes has some advantages over other methods. Thus, it can be performed with the use of mild reagents (which do not decompose peroxide) and it does not need an excess of hydrogen peroxide and substituted benzaldehyde.

\subsection{Acid-catalyzed condensation of $\beta$-diketones with hydrogen peroxide}

The acid-catalyzed condensation of $\beta$-diketones $414 a-l$ with hydrogen peroxide is a simple and facile method for the synthesis of bridged 1,2,4,5-tetraoxanes 415a-l. This method enables the synthesis of these compounds on the multigram scale in $47-77 \%$ yields (Scheme 127). The high concentration of a strong acid, such as $\mathrm{H}_{2} \mathrm{SO}_{4}, \mathrm{HBF}_{4}$, or $\mathrm{HClO}_{4}(2 \mathrm{~g}$ of the acid per $5 \mathrm{~mL}$ of the solvent) is the key factor determining the yield and selectivity of the synthesis of 1,2,4,5-tetraoxanes. Under these conditions, the targeted compounds are produced selectively even in the presence of an excess of hydrogen peroxide [428]. Unlike many compounds with the $\mathrm{O}-\mathrm{O}$ bond, which are rearranged in acidic media, the resulting cyclic peroxides are fairly stable under these reaction conditions.

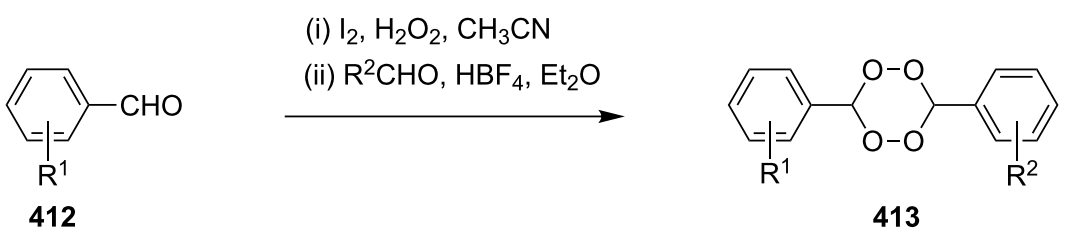


Table 26: lodine-catalyzed one-pot synthesis of tetraoxanes 413.

\begin{tabular}{|c|c|c|c|c|c|}
\hline \multicolumn{2}{|c|}{ Tetraoxane 413} & \multirow{2}{*}{ Yield, \% } & \multicolumn{2}{|c|}{ Tetraoxane 413} & \multirow{2}{*}{ Yield, \% } \\
\hline $\mathrm{R}^{1}$ & $\mathrm{R}^{2}$ & & $\mathrm{R}^{1}$ & $\mathrm{R}^{2}$ & \\
\hline o-Me & o-Me & 42 & $p-(t-B u)$ & $p-(n-\operatorname{Pr})$ & 32 \\
\hline o-Me & $m-\mathrm{Me}$ & 33 & $p-(t-\mathrm{Bu})$ & $p-(\mathrm{iPr})$ & 38 \\
\hline$p-\mathrm{Me}$ & $p-\mathrm{Me}$ & 54 & $p-(n-\operatorname{Pr})$ & $p-(\mathrm{iPr})$ & 28 \\
\hline$p-\mathrm{Me}$ & $p-(\mathrm{iPr})$ & 33 & $p-(t-\mathrm{Bu})$ & $p$-OMe & 22 \\
\hline$p-\mathrm{Me}$ & $p-(t-\mathrm{Bu})$ & 46 & $p-(\mathrm{iPr})$ & $p$-OMe & 24 \\
\hline$p-\mathrm{Me}$ & $p$-OMe & 25 & $p$-Et & $p-\mathrm{Me}$ & 41 \\
\hline$p-\mathrm{Me}$ & $p-\mathrm{CO}_{2} \mathrm{Me}$ & 37 & $p$-Et & $m-\mathrm{Me}$ & 39 \\
\hline$p-\mathrm{Me}$ & $\mathrm{o}-\mathrm{Me}$ & 25 & $p$-Et & $p-(\mathrm{iPr})$ & 37 \\
\hline$p-\mathrm{Me}$ & $m-\mathrm{Me}$ & 38 & $p$-Et & $p-(t-B u)$ & 25 \\
\hline$p-\mathrm{Me}$ & $p-(n-\operatorname{Pr})$ & 37 & $p-(n-\operatorname{Pr})$ & $p$-OMe & 24 \\
\hline$p-\mathrm{Me}$ & $\mathrm{H}$ & 43 & $p-\mathrm{Cl}$ & $p-\mathrm{Cl}$ & 25 \\
\hline$p-\mathrm{Me}$ & $p-\mathrm{CHO}$ & 31 & $p-\mathrm{Br}$ & $p-\mathrm{Br}$ & 22 \\
\hline$p-(n-\mathrm{Bu})$ & $p-(n-\mathrm{Bu})$ & 40 & $p-\mathrm{F}$ & $p-\mathrm{F}$ & 29 \\
\hline$p-(t-\mathrm{Bu})$ & $p-(t-\mathrm{Bu})$ & 53 & $p$-OMe & $p$-OMe & 27 \\
\hline$m-\mathrm{Me}$ & $m-\mathrm{Me}$ & 51 & $p$-Et & $p$-Et & 44 \\
\hline$m-\mathrm{Me}$ & $\mathrm{H}$ & 30 & $p-(n-\operatorname{Pr})$ & $p-(n-\operatorname{Pr})$ & 38 \\
\hline$m-\mathrm{Me}$ & $p$-OMe & 29 & $p-(\mathrm{iPr})$ & $p-(\mathrm{iPr})$ & 41 \\
\hline
\end{tabular}

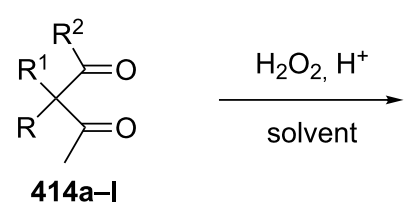

a: $R=B u, R^{1}=H, R^{2}=M e$

b: $R=B u, R^{1}=M e, R^{2}=M e$

c: $\mathrm{R}=\mathrm{CH}_{2}-\mathrm{CH}=\mathrm{CH}_{2}, \mathrm{R}^{1}=\mathrm{H} ; \mathrm{R}^{2}=\mathrm{Me}$

d: $\mathrm{R}=\mathrm{CH}_{2} \mathrm{CH}_{2} \mathrm{CN}, \mathrm{R}^{1}=\mathrm{H} ; \mathrm{R}^{2}=\mathrm{Me}$

e: $\mathrm{R}=\mathrm{CH}_{2} \mathrm{CH}_{2}$ COOEt, $\mathrm{R}^{1}=\mathrm{H}, \mathrm{R}^{2}=\mathrm{Me}$

f: $R=1$-adamantyl, $R^{1}=H, R^{2}=M e$

g: $\mathrm{R}=\mathrm{CH}_{2} \mathrm{Ph}, \mathrm{R}^{1}=\mathrm{H}, \mathrm{R}^{2}=\mathrm{Me}$

h: $\mathrm{R}=m-\mathrm{MePhCH}_{2}, \mathrm{R}^{1}=\mathrm{H}, \mathrm{R}^{2}=\mathrm{Me}$

i: $\mathrm{R}=p-\mathrm{MePhCH}_{2}, \mathrm{R}^{1}=\mathrm{H}, \mathrm{R}^{2}=\mathrm{Me}$

j: $\mathrm{R}=\mathrm{o}-\mathrm{MeOPhCH}_{2}, \mathrm{R}^{1}=\mathrm{H}, \mathrm{R}^{2}=\mathrm{Me}$

k: $\mathrm{R}=p-\mathrm{NO}_{2} \mathrm{PhCH}_{2}, \mathrm{R}^{1}=H, \mathrm{R}^{2}=\mathrm{Me}$

I: $R=R^{2}=-\left(\mathrm{CH}_{2}\right)_{4}-, \mathrm{R}^{1}=\mathrm{H}$

Scheme 127: Synthesis of bridged 1,2,4,5-tetraoxanes 415a-I from $\beta$-diketones 414a-I and $\mathrm{H}_{2} \mathrm{O}_{2}$.

It was found that phosphomolybdic acid and phosphotungstic acid efficiently catalyze the addition of $\mathrm{H}_{2} \mathrm{O}_{2}$ to $\beta$-diketones resulting in the selective formation of bridged 1,2,4,5-tetraoxanes. The use of these catalysts made it possible to obtain bridged tetraoxanes from easily oxidizable benzoylacetone derivatives and $\alpha$-unsubstituted $\beta$-diketones [429].

\subsection{Synthesis of symmetrical 1,2,4,5-tetraoxanes} by the ozonolysis of unsaturated compounds

The dimerization of zwitterions $\mathbf{4 1 7}$ produced by decomposition of ozonides 416 affords symmetrical tetraoxanes 418 (Scheme 128).

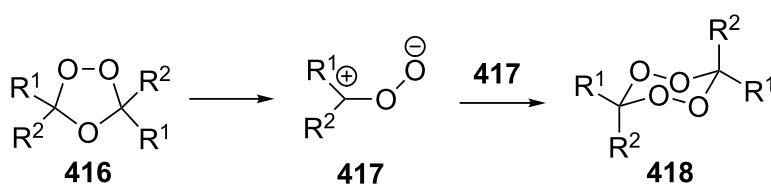

Scheme 128: Dimerization of zwitterions 417.

For example, the ozonolysis of verbenone 419 via the formation of zwitterioninc structures $\mathbf{4 2 0}$ and $\mathbf{4 2 1}$ gives a mixture of two symmetrical 1,2,4,5-tetraoxanes $\mathbf{4 2 2}$ and $\mathbf{4 2 3}$ (Scheme 129) [430]. Peroxides $\mathbf{4 2 2}$ and $\mathbf{4 2 3}$ are unstable due to the presence of carbonyl groups adjacent to the $\mathrm{O}-\mathrm{O}$ group, and they almost completely decompose as the temperature is raised.

3,3,6,6-Tetrapentyl-1,2,4,5-tetraoxane (425) was synthesized in a similar way by the ozonolysis of undecan-6-one O-methyl oxime (424) (Scheme 130) [431,432]. It should be noted that this approach is not widely used because of a limited number of appropriate structures and low yields of the target products. 

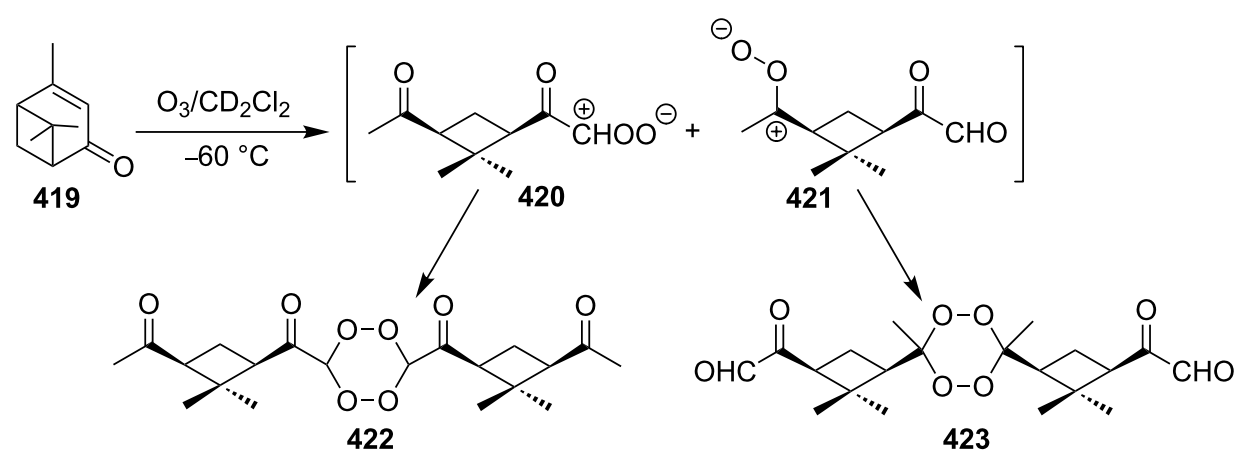

Scheme 129: Ozonolysis of verbenone 419

$$
\underset{\mathrm{C}_{5} \mathrm{H}_{11}}{\mathrm{C}_{5} \mathrm{H}_{11}} \underset{\mathrm{N}^{\mathrm{O}}}{\mathrm{O}-\mathrm{Me}} \frac{\mathrm{O}_{3}}{\mathrm{CCl}_{4}} \underset{\mathrm{C}_{5} \mathrm{H}_{11} \mathrm{O}-\mathrm{O}}{\mathrm{C}_{5} \mathrm{H}_{11}} X_{\mathrm{C}_{5} \mathrm{H}_{11}}^{\mathrm{O}-\mathrm{O}}
$$

424

$425,14 \%$

Scheme 130: Ozonolysis of O-methyl oxime 424.

\subsection{Other methods for the synthesis of $1,2,4,5-$ tetraoxanes}

The peroxidation of 1,1,1-trifluorododecan-2-one (426) with oxone afforded the symmetrical tetraoxane, 3,6-didecyl-3,6bis(trifluoromethyl)-1,2,4,5-tetraoxane (427) (Scheme 131) [433].

The synthesis of unsymmetrical steroidal tetraoxane $\mathbf{4 2 9}$ in $19 \%$ yield was performed by the intramolecular cyclization of dialdehyde $\mathbf{4 2 8}$ with hydrogen peroxide under acidic conditions (Scheme 132) [434].
In the synthesis of geminal bishydroperoxides by $\mathrm{BF}_{3} \cdot \mathrm{Et}_{2} \mathrm{O}$ or $\mathrm{BF}_{3} \cdot \mathrm{MeOH}$-catalyzed reactions of ketals 430-432 with hydrogen peroxide in $\mathrm{Et}_{2} \mathrm{O}$ tetraoxanes 433-435 (Scheme 133) are obtained as by-products in $12 \%, 6 \%$, and $19 \%$ yields, respectively [435].

Scheme 134 shows the synthesis of 3,3,6,6-tetramethyl-1,2,4,5tetraoxane (437) in $90 \%$ yield by the transformation of the intermediate 3,3,6,6,9,9-hexamethyl-1,2,4,5,7,8-hexaoxononane (436) in acetone [436]. This method is suitable for the preparation of the target product in amounts of only several hundred milligrams.

6.11. Structural modifications, in which 1,2,4,5tetraoxane ring remains intact

In the last two decades, 1,2,4,5-tetraoxanes were considered as the most promising compounds for the design of antiparasitic drugs. This is due, first, to the high activity of their derivatives

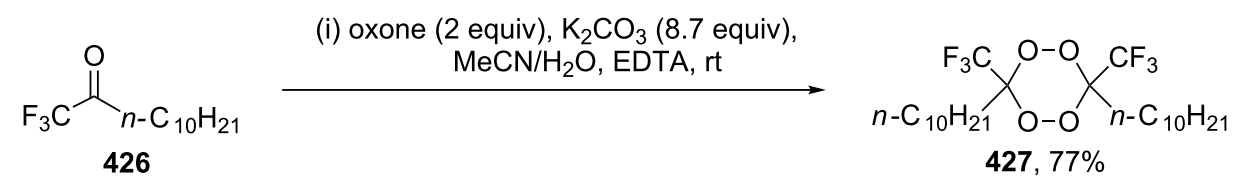

Scheme 131: Peroxidation of 1,1,1-trifluorododecan-2-one 426 with oxone.

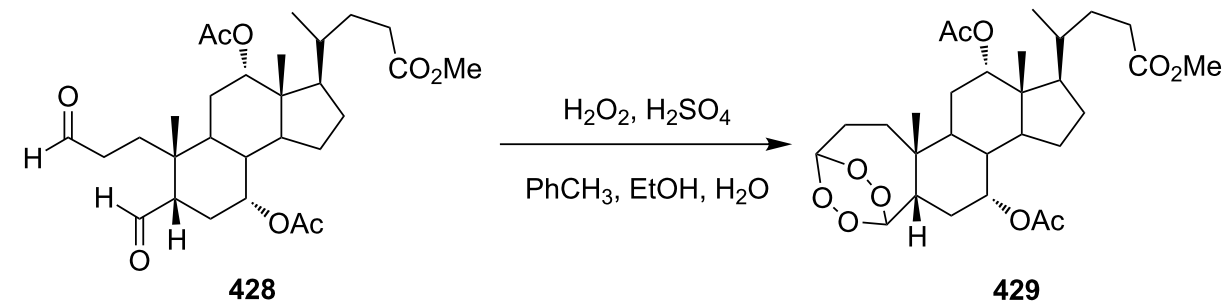

Scheme 132: Intramolecular cyclization of dialdehyde 428 with $\mathrm{H}_{2} \mathrm{O}_{2}$. 


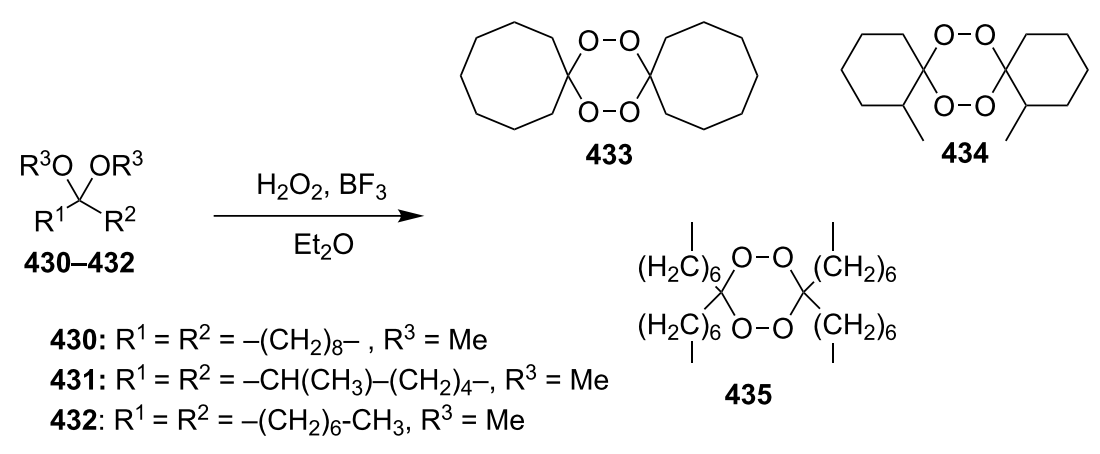

Scheme 133: Tetraoxanes $\mathbf{4 3 3 - 4 3 5}$ as by-products in peroxidation of ketals $\mathbf{4 3 0 - 4 3 2 . ~}$

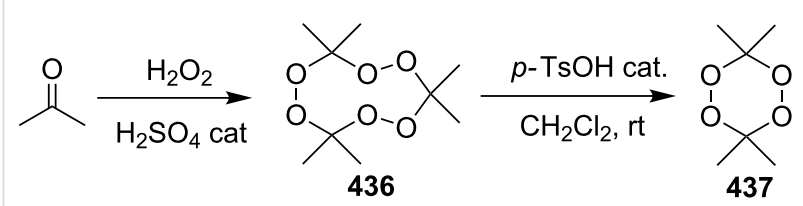

Scheme 134: Transformation of triperoxide 436 in diperoxide 437. and, second, to a wide scope of structural modifications, in which the tetraoxane ring remains intact.

Amides 440a,b and amines 444a,b, and 446 active against various strains of P.falciparum were synthesized from methyl 7,8,15,16-tetraoxadispiro[5.2.5.2] hexadecane-3-carboxylate (438) containing the ester group (Scheme 135) [135,437]. To prepare aminoquinoline derivatives $440 \mathrm{a}, \mathrm{b}$, ester 438 was

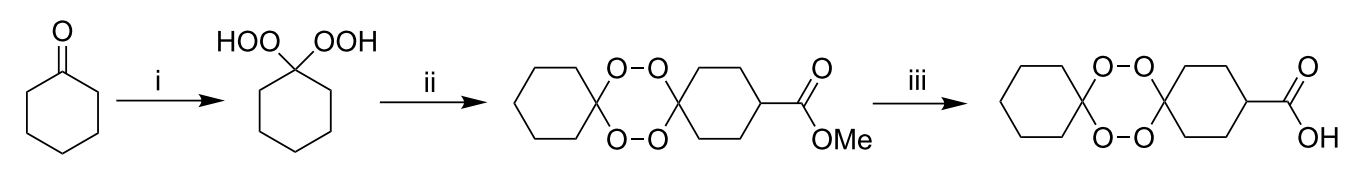

$402,50 \%$

$438,28 \%$
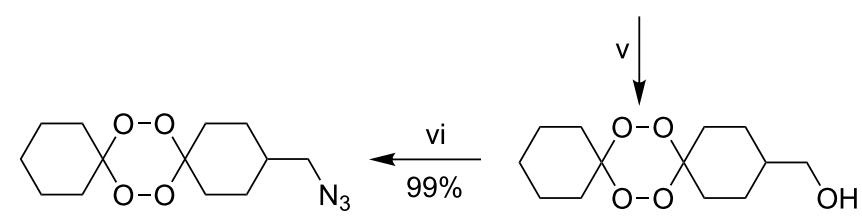

$442,99 \%$

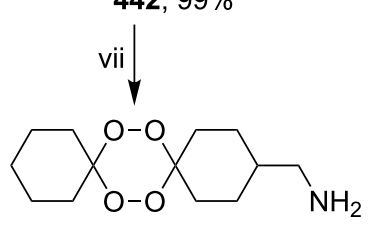

$443,60 \%$

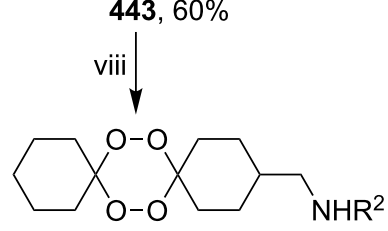

444a $\mathrm{R}^{2}=\mathrm{C}_{6} \mathrm{H}_{11}, 48 \%$

444b $R^{2}=i \operatorname{Pr}, 67 \%$
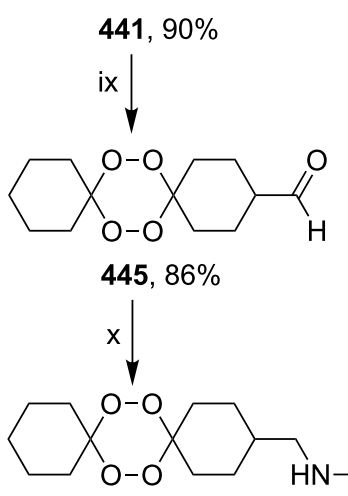

446, $64 \%$

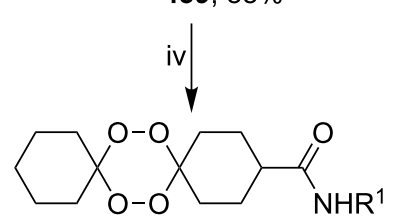

$440 \mathrm{a} \mathrm{R}{ }^{1}=\left(\mathrm{CH}_{2}\right)_{2} \mathrm{NMe}_{2}, 90 \%$

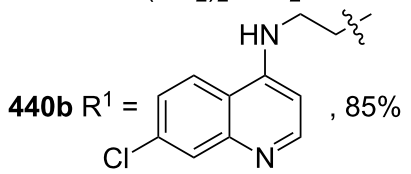

(i) $30 \% \mathrm{H}_{2} \mathrm{O}_{2} / \mathrm{HCl}, \mathrm{CH}_{3} \mathrm{CN} / \mathrm{CH}_{2} \mathrm{Cl}_{2}$; (ii) methyl 4-oxocyclohexanecarboxylate, $\mathrm{CH}_{2} \mathrm{Cl}_{2}, \mathrm{H}_{2} \mathrm{SO}_{4} / \mathrm{CH}_{3} \mathrm{CN}$;

(iii) $\mathrm{NaOH}$, iPrOH/ $\mathrm{H}_{2} \mathrm{O} /$ reflux; (iv) $\mathrm{ClCO}_{2} \mathrm{Et} / \mathrm{Et} 3 \mathrm{~N}$, amine, $\mathrm{CH}_{2} \mathrm{Cl}_{2}$; (v) $\mathrm{LiAlH}_{4}, \mathrm{Et}_{2} \mathrm{O}$;

(vi) (1) $\mathrm{MeSO}_{2} \mathrm{Cl}$, pyridine, (2) $\mathrm{NaN}_{3}$, DMF; (vii) $\mathrm{LiAlH}_{4}, \mathrm{Et}_{2} \mathrm{O}$;

(viii) carbonyl compound, $\mathrm{NaBH}(\mathrm{OAc})_{3}, \mathrm{CH}_{2} \mathrm{Cl}_{2}$; (ix) pyridinium chlorochromate, $\mathrm{CH}_{2} \mathrm{Cl}_{2}$;

(x) amine, $\mathrm{NaBH}(\mathrm{OAc})_{3}, \mathrm{CH}_{2} \mathrm{Cl}_{2}$ 
hydrolyzed to 7,8,15,16-tetraoxadispiro[5.2.5.2] hexadecane-3carboxylic acid (439) followed by the amidation of the latter. The synthesis of products $\mathbf{4 4 4 a , b}$ and $\mathbf{4 4 6}$ was performed with a wide range of classical reagents for organic synthesis with the intermediate formation of compounds containing such groups as hydroxy 441 , azide 442 , amino 443 , and aldehyde 445 .

An interesting feature of the synthesis according to Scheme 135 is the use of such strong reducing agents as $\mathrm{LiAlH}_{4}$ and $\mathrm{NaBH}(\mathrm{OAc})_{3}$, with the products retaining the peroxide ring.

Steroidal tetraoxane $\mathbf{4 4 8}$, which is approximately six times more active that Artelinic acid and 2.4 times as active as arteether against $P$. falciparum, was also synthesized by the alkaline hydrolysis of ester $\mathbf{4 0 1} \mathrm{g}$ followed by the amidation of acid 447 (Scheme 136) [128].

Compounds containing a fluorescent moiety are of interest in terms of the mechanism of antiparasitic action of peroxides. For example, 1,2,4,5-tetraoxane $\mathbf{4 5 4}$ containing the 4-chloro-7methylbenzo[c][1,2,5]oxadiazole moiety was synthesized according to Scheme 137. In the first step, ketone 449 was transformed in tetraoxane $\mathbf{4 5 0}$, whose ester group was subjected to the alkaline hydrolysis to form acid $\mathbf{4 5 1}$ followed by the amidation to give $\mathbf{4 5 2}$ and the hydrolysis to obtain hydrochlo- ride 453. Then the reaction of the latter with 4-chloro-7nitrobenzo[ $c][1,2,5]$ oxadiazole afforded the target compound 454 [138].

The synthesis of tetraoxane $\mathbf{4 5 8}$ (RKA182) exhibiting the in vitro and in vivo activity comparable with that of artemisinin was performed on the kilogram scale according to Scheme 138. This compound is a promising malaria drug candidate [82,83]. The key steps in this synthesis are the preparation of adamantane-containing tetraoxane $\mathbf{4 5 6}$ from ethyl 2-(4oxocyclohexyl)acetate (455), the hydrolysis of $\mathbf{4 5 6}$, and the purification to obtain acid $\mathbf{4 5 7}$. The amidation of the latter affords target product $\mathbf{4 5 8}$.

\section{Conclusion}

The review summarizes and generalizes studies on the synthesis of five- and six-membered cyclic peroxides published last decade (since 2000 to present). Most of the currently established methods for the synthesis of these compounds are based on the use of such key oxidizing agents as oxygen, ozone, and hydrogen peroxide. The Isayama-Mukaiyama and Kobayashi methods are widely used in the synthesis of 1,2-dioxolanes, 1,2dioxanes, and 1,2,4-trioxanes. The reactions with the participation of peroxycarbenium ions play an important role in the synthesis of peroxides.

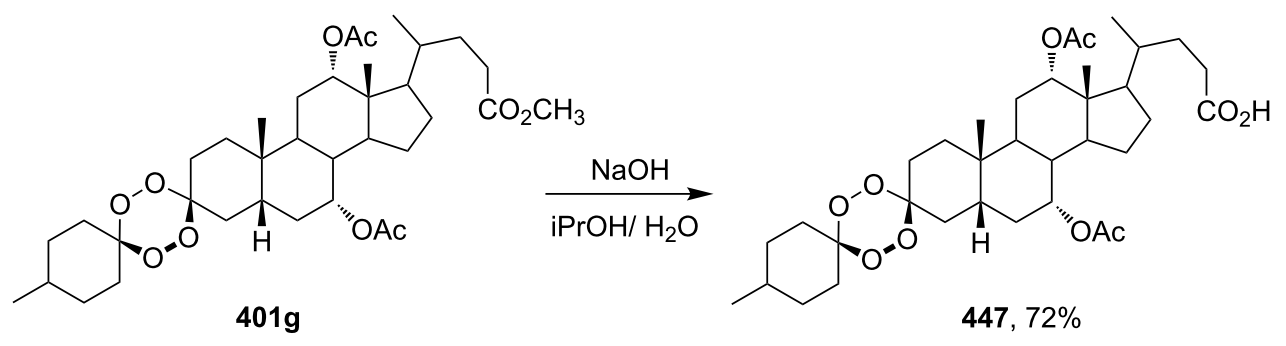

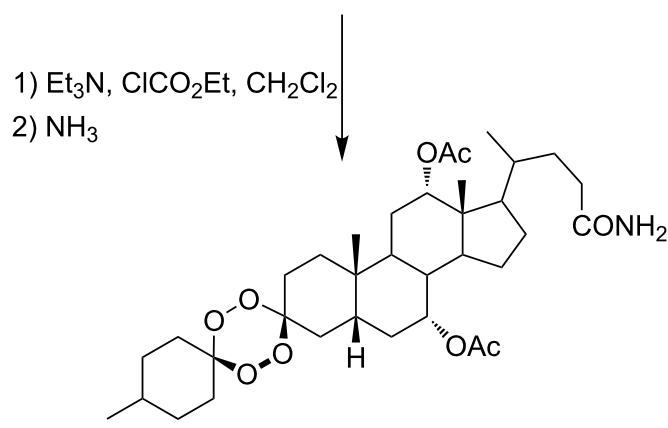

448, $74 \%$ 


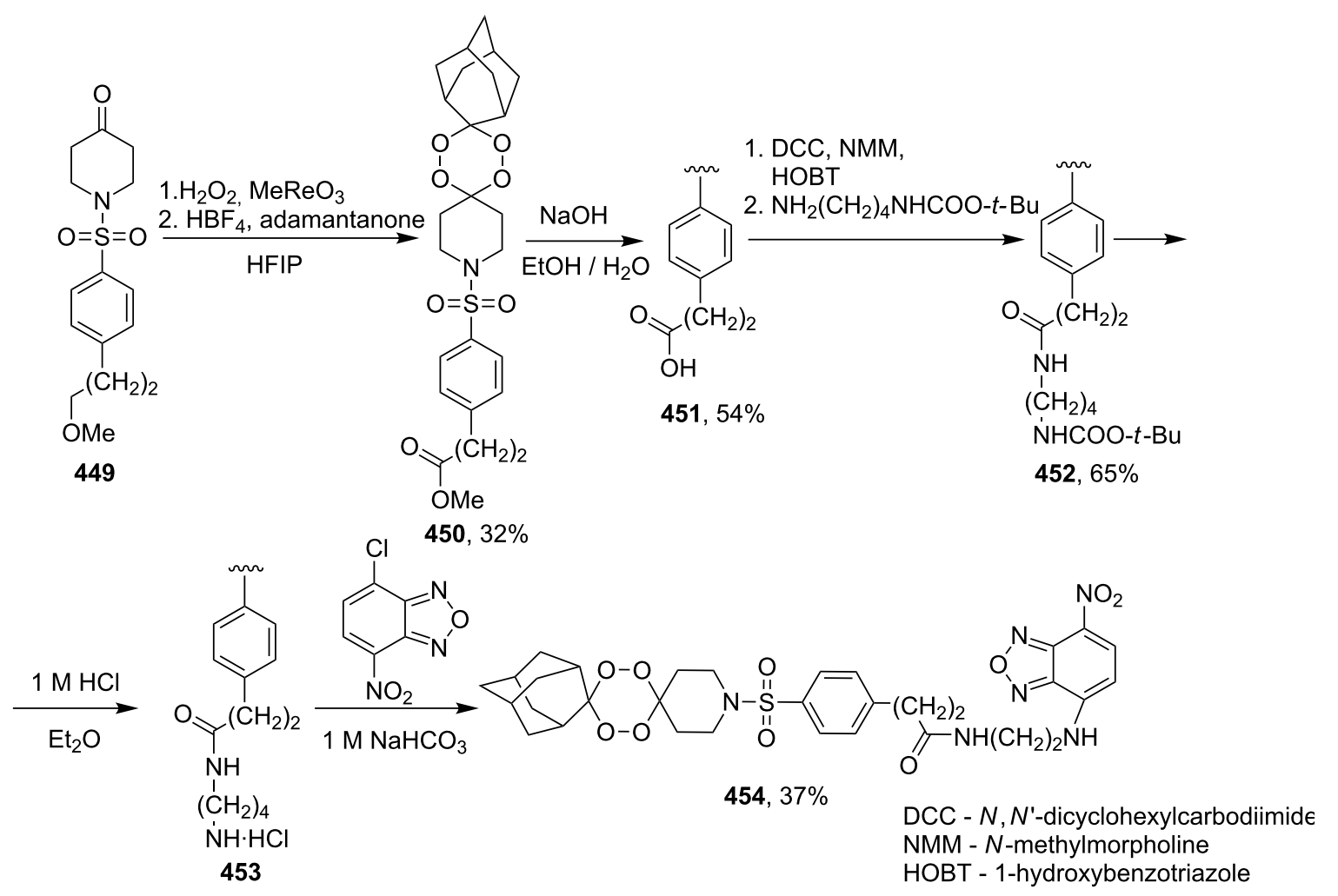

Scheme 137: Synthesis of 1,2,4,5-tetraoxane 454 containing the fluorescent moiety.
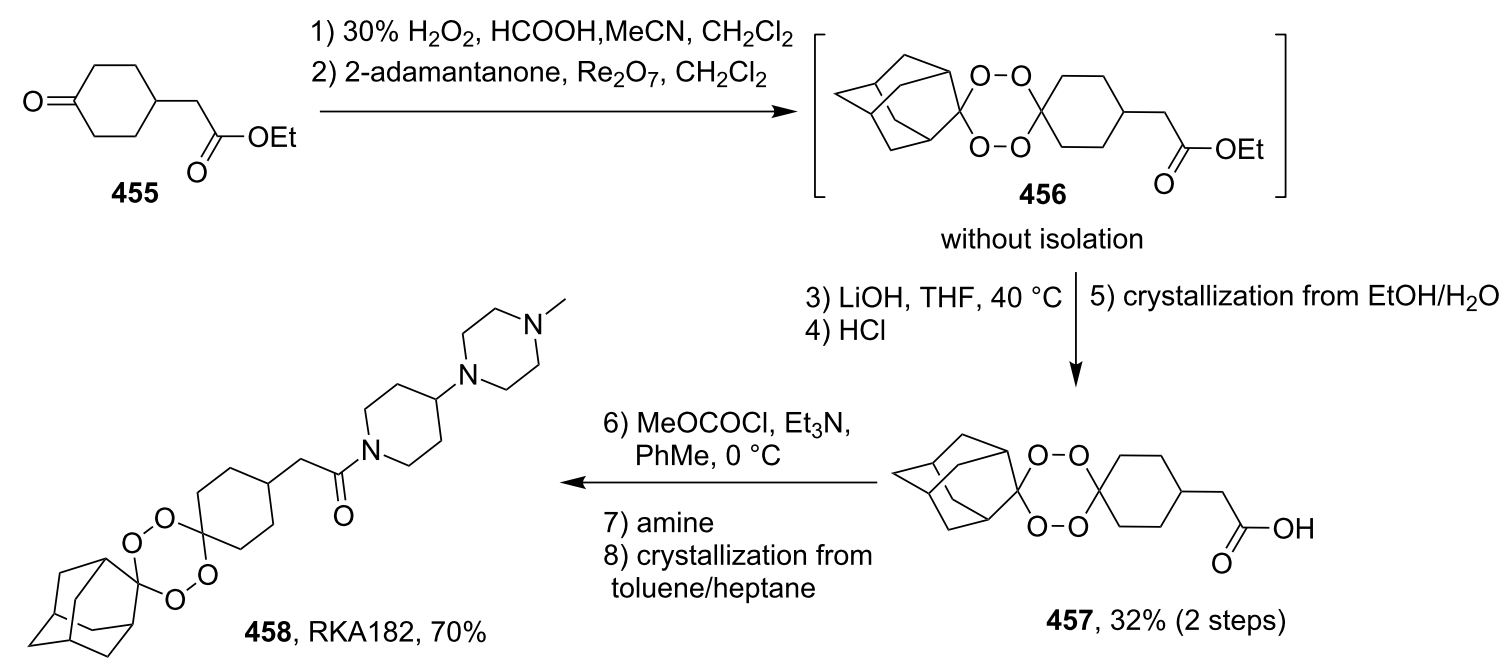

6) $\mathrm{MeOCOCl}, \mathrm{Et}_{3} \mathrm{~N}$, $\mathrm{PhMe}, 0^{\circ} \mathrm{C}$

7) amine
8) crystallization from
toluene/heptane

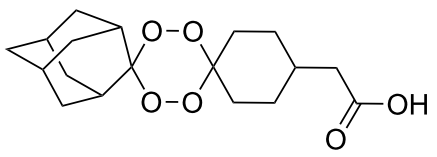

457, 32\% (2 steps)

Scheme 138: Synthesis of tetraoxane 458 (RKA182).

The Griesbaum coozonolysis of ketones and O-alkyl oximes is the most flexible and efficient method for the synthesis of unsymmetrical 1,2,4-trioxolanes. The [4+2]-cycloaddition of oxygen to a 1,3-diene system is, in fact, the only route to 1,2dioxenes.
Methods for the synthesis of 1,2,4,5-tetraoxanes are based on reactions of ketones, aldehydes, and their dialkyloxy derivatives with hydrogen peroxide or gem-bishydroperoxides catalyzed by protic and aprotic acids, such as $\mathrm{MeReO}_{3}, \mathrm{Re}_{2} \mathrm{O}_{7}$, and iodine. 
Modifications of functional groups to form peroxide ringretaining products are applicable to the synthesis of cyclic peroxides of various structural types. This approach can be used to prepare complex peroxides exhibiting antiparasitic and antitumor activities.

Carbonyl compound are generally employed as the starting reagents in the synthesis of cyclic peroxides. These methods can be used for the selective peroxidation of monocarbonyl compounds. In the case of dicarbonyl compounds, there are a limited number of efficient procedures for the synthesis of cyclic peroxides.

\section{Acknowledgements}

This work is supported by the Russian Foundation for Basic Research (Grant 14-03-00237-a), the Program for Basic Research of the Presidium of the Russian Academy of Sciences, and the Ministry of Education and Science of the Russian Federation (Grant 8651).

\section{References}

1. McCullough, K. J.; Nojima, M. Curr. Org. Chem. 2001, 5, 601. doi:10.2174/1385272013375346

2. Korshin, E. E.; Bachi, M. D. Synthesis of cyclic peroxides. In The Chemistry of Peroxides; Rappoport, Z., Ed.; John Wiley \& Sons, Ltd: Chichester, 2006; Vol. 2, Part 1, pp $189 \mathrm{ff}$. doi:10.1002/0470862769.ch5

3. Tang, Y.; Dong, Y.; Vennerstrom, J. L. Med. Res. Rev. 2004, 24, 425. doi:10.1002/med.10066

4. O'Neill, P. M.; Posner, G. H. J. Med. Chem. 2004, 47, 2945 doi:10.1021/jm030571c

5. Slack, R. D.; Jacobine, A. M.; Posner, G. H. Med. Chem. Commun. 2012, 3, 281. doi:10.1039/c2md00277a

6. Masuyama, A.; Wu, J.-M.; Nojima, M.; Kim, H.-S.; Wataya, Y. Mini-Rev. Med. Chem. 2005, 5, 1035. doi:10.2174/138955705774575255

7. Van Ornum, S. G.; Champeau, R. M.; Pariza, R. Chem. Rev. 2006, 106, 2990. doi:10.1021/cr040682z

8. Jefford, C. W. Drug Discovery Today 2007, 12, 487. doi:10.1016/j.drudis.2007.04.009

9. Jefford, C. W. Curr. Top. Med. Chem. 2012, 12, 373. doi:10.2174/156802612799362940

10. Dembitsky, V. M. Eur. J. Med. Chem. 2008, 43, 223. doi:10.1016/j.ejmech.2007.04.019

11. Siddiq, A.; Dembitsky, V. Anti-Cancer Agents Med. Chem. 2008, 8, 132. doi:10.2174/187152008783497073

12. Dembitsky, V. M.; Levitsky, D. O. Nat. Prod. Commun. 2006, 1, 405.

13. Dembitsky, V. M. Lipids 2006, 41, 883 doi:10.1007/s11745-006-5044-3

14. Dembitsky, V. M. Lipids 2005, 40, 869. doi:10.1007/s11745-005-1449-2

15. Dembitsky, V. M. Chem. Biodiversity 2004, 1, 673. doi:10.1002/cbdv.200490060

16. Opsenica, D. M.; Šolaja, B. A. J. Serb. Chem. Soc. 2009, 74, 1155. doi:10.2298/JSC09111550
17. Muraleedharan, K. M.; Avery, M. A. Drug Discovery Today 2009, 14, 793. doi:10.1016/j.drudis.2009.05.008

18. Kim, B. J.; Sasaki, T. Org. Prep. Proced. Int. 2006, 38, 1. doi:10.1080/00304940609355981

19. Baby, J.; Sujatha, S. J. Nat. Prod. (Gorakhpur, India) 2011, 4, 5.

20. Hepworth, J. D.; Heron, B. M. Prog. Heterocycl. Chem. 1996, 8, 277. doi:10.1016/S0959-6380(96)80017-1

21. Kabal'nova, N. N.; Khursan, S. L.; Shereshovets, V. V.; Tolstikov, G. A. Kinet. Catal. 1999, 40, 207.

22. Terent'ev, A. O.; Platonov, M. M.; Levitsky, D. O.; Dembitsky, V. M. Russ. Chem. Rev. 2011, 80, 807. doi:10.1070/RC2011v080n09ABEH004189

23. Baader, W. J.; Bastos, E. L. Sci. Synth. 2008, 38, 345-378.

24. Baader, W. J.; Bastos, E. L. Sci. Synth. 2008, 38, 379-395.

25. Baader, W. J.; Bastos, E. L. Sci. Synth. 2008, 38, 397-420.

26. Kumar, N.; Singh, R.; Rawat, D. S. Med. Res. Rev. 2012, 32, 581-610. doi:10.1002/med.20223

27. Zmitek, K.; Zupan, M.; Iskra, J. Org. Biomol. Chem. 2007, 5, 3895. doi:10.1039/b711647k

28. Trullinger, T. K. Ph.D. Thesis, University of Nebraska, Lincoln, NE, USA, 2002; pp $195 \mathrm{ff}$. Diss. Abstr. Int., B 2003, 63, 5855.

29. Dai, P. Ph.D. Thesis, University of Nebraska, Lincoln, NE, USA, 2004; pp $186 \mathrm{ff}$. Diss. Abstr. Int., B 2005, 66, 281.

30. Ramirez, A. P. Ph.D. Thesis, University of California, Irvine, CA, USA, 2007; pp 224 ff.

Diss. Abstr. Int., B 2007, 67, 6412.

31. Pena-Quevedo, A. J. Ph.D. Thesis, University of Puerto Rico, Mayaguez, P. R., 2009; pp $159 \mathrm{ff}$. Diss. Abstr. Int., B 2010, 70, 4186.

32. Yao, G. Ph.D. Thesis, Boston University, Boston, MA, USA, 1999; pp $243 \mathrm{ff}$. Diss. Abstr. Int., B 1999, 60, 193.

33. Morgan, N. N. Int. J. Phys. Sci. 2009, 4, 885.

34. Odinokov, V. N.; Tolstikov, G. A. Russ. Chem. Rev. 1981, 50, 636. doi:10.1070/RC1981v050n07ABEH002658

35. Razumovskii, S. D.; Zaikov, G. E. Russ. Chem. Rev. 1980, 49, 1163. doi:10.1070/RC1980v049n12ABEH002535

36. Schmidt-Szalowski, K. Przem. Chem. 2000, 79, 115.

37. Capon, R. J. Stud. Nat. Prod. Chem. 1991, 9, 15.

38. Cafferata, L. F. R. Trends Org. Chem. 1993, 4, 773.

39. Tolstikov, G. A.; Tolstikov, A. G.; Tolstikova, O. V. Russ. Chem. Rev. 1996, 65, 769. doi:10.1070/RC1996v065n09ABEH000240

40. McCullough, K. J. Contemp. Org. Synth. 1995, 2, 225. doi:10.1039/co9950200225

41. Adam, W. Acc. Chem. Res. 1979, 12, 390. doi:10.1021/ar50143a002

42. Opsenica, D. M.; Šolaja, B. A. Maced. J. Chem. Chem. Eng. 2012, 31, 137.

43. Sawwan, N.; Greer, A. Chem. Rev. 2007, 107, 3247. doi:10.1021/cr0400717

44. Clennan, E. L.; Foote, C. In Organic Peroxides; Ando, E., Ed.; Wiley: New York, 1992.

45. Balci, M. Chem. Rev. 1981, 81, 91. doi:10.1021/cr00041a005

46. Clennan, E. L. Tetrahedron 1991, 47, 1343. doi:10.1016/S0040-4020(01)86413-9

47. Doerig, C. D. Nat. Chem. Biol. 2008, 4, 334. doi:10.1038/nchembio0608-334

48. Vangapandu, S.; Jain, M.; Kaur, K.; Patil, P.; Patel, S. R.; Jain, R. Med. Res. Rev. 2007, 27, 65. doi:10.1002/med.20062 
49. Tu, Y. Nat. Med. (N. Y., NY, U. S.) 2011, 17, 1217. doi:10.1038/nm.2471

50. Kumar, N.; Sharma, M.; Rawat, D. S. Curr. Med. Chem. 2011, 18, 3889. doi:10.2174/092986711803414340

51. Liao, F. Molecules 2009, 14, 5362. doi:10.3390/molecules 14125362

52. Morris, C. A.; Duparc, S.; Borghini-Fuhrer, I.; Jung, D.; Shin, C.-S.; Fleckenstein, L. Malar. J. 2011, 10, 263. doi:10.1186/1475-2875-10-263

53. Robert, A.; Dechy-Cabaret, O.; Cazalles, J.; Meunier, B. Acc. Chem. Res. 2002, 35, 167-174. doi:10.1021/ar990164o

54. Hombhanje, F. W.; Huang, Q. Pharmaceuticals 2010, 3, 3581. doi:10.3390/ph3123581

55. Kano, S. J. Infect. Chemother. 2010, 16, 375. doi:10.1007/s10156-010-0077-1

56. Li, Q.; Weina, P. Pharmaceuticals 2010, 3, 2322. doi:10.3390/ph3072322

57. Wright, C. W. Nat. Prod. Rep. 2010, 27, 961. doi:10.1039/c002196m

58. Kaur, H.; Green, M. D.; Hostetler, D. M.; Fernandez, F. M.; Newton, P. N. Therapy 2010, 7, 49. doi:10.2217/thy.09.84

59. Medhi, B.; Patyar, S.; Rao, R. S.; Byrav, D. S. P.; Prakash, A. Pharmacology 2009, 84, 323. doi:10.1159/000252658

60. Eastman, R. T.; Fidock, D. A. Nat. Rev. Microbiol. 2009, 7, 864. doi:10.1038/nrmicro2239

61. Ehrhardt, S.; Meyer, C. G. Ther. Clin. Risk Manage. 2009, 5, 805. doi:10.2147/TCRM.S5375

62. Gautam, A.; Ahmed, T.; Paliwal, J.; Batra, V. Curr. Drug Metab. 2009, 10, 289. doi:10.2174/138920009787846323

63. Bathurst, I.; Hentschel, C. Trends Parasitol. 2006, 22, 301. doi:10.1016/j.pt.2006.05.011

64. White, N. J. Science 2008, 320, 330. doi:10.1126/science.1155165

65. Nakase, I.; Lai, H.; Singh, N. P.; Sasaki, T. Int. J. Pharm. 2008, 354, 28. doi:10.1016/j.ijpharm.2007.09.003

66. Nosten, F.; White, N. J. Am. J. Trop. Med. Hyg. 2007, 77 (Suppl. 6), 181.

67. Stocks, P. A.; Bray, P. G.; Barton, V. E.; Al-Helal, M.; Jones, M.; Araujo, N. C.; Gibbons, P.; Ward, S. A.; Hughes, R. H.; Biagini, G. A.; Davies, J.; Amewu, R.; Mercer, A. E.; Ellis, G.; ONeill, P. M. Angew. Chem., Int. Ed. 2007, 46, 6278. doi:10.1002/anie.200604697

68. Checkley, A. M.; Whitty, C. J. M. Expert Rev. Anti-Infect. Ther. 2007, 5, 199. doi:10.1586/14787210.5.2.199

69. Tilley, L.; Davis, T. M. E.; Bray, P. G. Future Microbiol. 2006, 1, 127. doi:10.2217/17460913.1.1.127

70. Gelb, M. H. Curr. Opin. Chem. Biol. 2007, 11, 440. doi:10.1016/j.cbpa.2007.05.038

71. Namdeo, A. G.; Mahadik, K. R.; Kadam, S. S. Pharm. Mag. 2006, 2, 106.

72. Haynes, R. K. Curr. Top. Med. Chem. (Sharjah, United Arab Emirates) 2006, 6, 509. doi:10.2174/156802606776743129

73. Begue, J.-P.; Bonnet-Delpon, D. Drugs Future 2005, 30, 509. doi:10.1358/dof.2005.030.05.901987

74. Rosenthal, A. S.; Chen, X.; Liu, J. O.; West, D. C.; Hergenrother, P. J.; Shapiro, T. A.; Posner, G. H. J. Med. Chem. 2009, 52, 1198. doi:10.1021/jm801484v

75. Nagelschmitz, J.; Voith, B.; Wensing, G.; Roemer, A.; Fugmann, B.; Haynes, R. K.; Kotecka, B. M.; Rieckmann, K. H.; Edstein, M. D. Antimicrob. Agents Chemother. 2008, 52, 3085. doi:10.1128/AAC.01585-07

76. Van der Meersch, H. J. Pharm. Belg. 2005, 60, 23.
77. Vennerstrom, J. L.; Arbe-Barnes, S.; Brun, R.; Charman, S. A.; Chiu, F. C. K.; Chollet, J.; Dong, Y.; Dorn, A.; Hunziker, D.; Matile, H.; McIntosh, K.; Padmanilayam, M.; Santo Tomas, J.; Scheurer, C.; Scorneaux, B.; Tang, Y.; Urwyler, H.; Wittlin, S.; Charman, W. N. Nature 2004, 430, 900. doi:10.1038/nature02779

78. Valecha, N.; Looareesuwan, S.; Martensson, A.; Abdulla, S. M.; Krudsood, S.; Tangpukdee, N.; Mohanty, S.; Mishra, S. K.; Tyagi, P. K.; Sharma, S. K.; Moehrle, J.; Gautam, A.; Roy, A.; Paliwal, J. K.; Kothari, M.; Saha, N.; Dash, A. P.; Bjorkman, A. Clin. Infect. Dis. 2010, 51, 684. doi:10.1086/655831

79. Uhlemann, A. C.; Wittlin, S.; Matile, H.; Bustamante, L. Y.; Krishna, S. Antimicrob. Agents Chemother. 2007, 51, 667. doi:10.1128/AAC.01064-06

80. Gupta, A.; Singh, Y.; Srinivas, K. S.; Jain, G.; Sreekumar, V. B.; Semwal, V. P. J. Pharm. BioAllied Sci. 2010, 2, 32. doi:10.4103/0975-7406.62706

81. Dong, Y.; Wittlin, S.; Sriraghavan, K.; Chollet, J.; Charman, S. A.; Charman, W. N.; Scheurer, C.; Urwyler, H.; Santo Tomas, J.; Snyder, C.; Creek, D. L.; Morizzi, J.; Koltun, M.; Matile, H.; Wang, X.; Padmanilayam, M.; Tang, Y.; Dorn, A.; Brun, R.; Vennerstrom, J. L. J. Med. Chem. 2010, 53, 481. doi:10.1021/jm901473s

82. O'Neill, P. M.; Amewu, R. K.; Nixon, G. L.; ElGarah, F. B.; Mungthin, M.; Chadwick, J.; Shone, A. E.; Vivas, L.; Lander, H.; Barton, V.; Muangnoicharoen, S.; Bray, P. G.; Davies, J.; Park, B. K.; Wittlin, S.; Brun, R.; Preschel, M.; Zhang, K.; Ward, S. A. Angew. Chem., Int. Ed. 2010, 49, 5693. doi:10.1002/anie.201001026

83. Bousejra-El Garah, F.; Wong, M. H.-L.; Amewu, R. K.; Muangnoicharoen, S.; Maggs, J. L.; Stigliani, J.-L.; Park, B. K.; Chadwick, J.; Ward, S. A.; O'Neill, P. M. J. Med. Chem. 2011, 54, 6443. doi:10.1021/jm200768h

84. Posner, G. H.; O'Neill, P. M. Acc. Chem. Res. 2004, 37, 397. doi:10.1021/ar020227u

85. Sonnet, P.; Mullié, C. Exp. Parasitol. 2011, 128, 26. doi:10.1016/j.exppara.2011.01.018

86. Coslédan, F.; Fraisse, L.; Pellet, A.; Guillou, G.; Mordmüller, M.; Kremsner, P.; Moreno, A.; Mazier, D.; Maffrand, J.-P.; Meunier, B. Proc. Natl. Acad. Sci. U. S. A. 2008, 105, 17579. doi:10.1073/pnas.0804338105

87. Meunier, B.; Robert, A. Acc. Chem. Res. 2010, 43, 1444. doi:10.1021/ar100070k

88. Martyn, D. C.; Ramirez, A. P.; Beattie, M. J.; Cortese, J. F.; Patel, V.; Rush, M. A.; Woerpel, K. A.; Clardy, J. Bioorg. Med. Chem. Lett. 2008, 18, 6521. doi:10.1016/j.bmcl.2008.10.083

89. Schiaffo, C. E.; Rottman, M.; Wittlin, S.; Dussault, P. H. ACS Med. Chem. Lett. 2011, 2, 316.

90. Wang, X.; Dong, Y.; Wittlin, S.; Creek, D.; Chollet, J.; Charman, S. A.; Santo Tomas, J.; Scheurer, C.; Snyder, C.; Vennerstrom, J. L. J. Med. Chem. 2007, 50, 5840. doi:10.1021/jm0707673

91. Hartwig, C. L.; Lauterwasser, E. M. W.; Mahajan, S. S.; Hoke, J. M.; Cooper, R. A.; Renslo, A. R. J. Med. Chem. 2011, 54, 8207. doi:10.1021/jm2012003

92. Dong, Y.; Chollet, J.; Matile, H.; Charman, S. A.; Chiu, F. C. K.; Charman, W. N.; Scorneaux, B.; Urwyler, H.; Santo Tomas, J.; Scheurer, C.; Snyder, C.; Dorn, A.; Wang, X.; Karle, J. M.; Tang, Y.; Wittlin, S.; Brun, R.; Vennerstrom, J. L. J. Med. Chem. 2005, 48, 4953. doi:10.1021/jm049040u 
93. Dong, Y.; Tan, Y.; Chollet, J.; Matile, H.; Wittlin, S.; Charman, S. A.; Charman, W. N.; Tomas, J. S.; Scheurer, C.; Snyder, C.; Scorneaux, B.; Bajpai, S.; Alexander, S. A.; Wang, X.; Padmanilayam, M.; Cheruku, S. R.; Brun, R.; Vennerstrom, J. L. Bioorg. Med. Chem. 2006, 14, 6368. doi:10.1016/j.bmc.2006.05.041

94. Padmanilayam, M.; Scorneaux, B.; Dong, Y.; Chollet, J.; Matile, H.; Charman, S. A.; Creek, D. J.; Charman, W. N.; Tomas, J. S.; Scheurer, C.; Wittlin, S.; Brun, R.; Vennerstrom, J. L. Bioorg. Med. Chem. Lett. 2006, 16, 5542. doi:10.1016/j.bmcl.2006.08.046

95. Yadav, G. C.; Dorwal, H. N.; Tanwar, P.; Gahlot, U. B. S. A process for the preparation of 1, 2, 4-trioxolane antimalarials. PCT Int. Appl. WO2010119425 A1, Oct 21, 2010.

96. Tang, Y.; Dong, Y.; Wittlin, S.; Charman, S. A.; Chollet, J.; Chiu, F. C. K.; Charman, W. N.; Matile, H.; Urwyler, H.; Dorn, A.; Bajpai, S.; Wang, X.; Padmanilayam, M.; Karle, J. M.; Brun, R.; Vennerstrom, J. L. Bioorg. Med. Chem. Lett. 2007, 17, 1260. doi:10.1016/j.bmcl.2006.12.007

97. Tang, Y.; Wittlin, S.; Charman, S. A.; Chollet, J.; Chiu, F. C. K.; Morizzi, J.; Johnson, L. M.; Santo Tomas, J.; Scheurer, C.; Snyder, C.; Zhou, L.; Dong, Y.; Charman, W. N.; Matile, H.; Urwyler, H.; Dorn, A.; Vennerstrom, J. L. Bioorg. Med. Chem. Lett. 2010, 20, 563. doi:10.1016/j.bmcl.2009.11.088

98. Arora, V. K.; Madan, S.; Trehan, A.; Tyagi, P. Stable dosage forms of spiro and dispiro 1,2,4-trioxolane antimalarials. PCT Int. Appl. WO 2006123314 A2, Nov 23, 2006.

99. Vennerstrom, J. L.; Dong, Y.; Chollet, J.; Matile, H.; Wang, X.; Sriraghavan, K.; Charman, W. N. Spiro and dispiro 1,2,4-trioxolane antimalarials. U. S. Pat. Appl. US 20050256185 A1, Nov 17, 2005

100.Cazelles, J.; Cosledan, F.; Meunier, B.; Pellet, A. Dual molecules containing peroxy derivative, the synthesis and therapeutic applications thereof. Patent Fr. Demande FR 2862304 A1, May 20, 2005.

101.Vennerstrom, J. L.; Dong, Y.; Chollet, J.; Matile, H.; Padmanilayam, H.; Tang, Y.; Charman, N. W. Spiro and dispiro 1,2,4-trioxolane antimalarials. U.S. Pat. Appl. US 20040186168 A1, Sept 23, 2004.

102. O'Neill, P. M.; Stocks, P. A.; Pugh, M. D.; Araujo, N. C.; Korshin, E. E.; Bickley, J. F.; Ward, S. A.; Bray, P. G.; Pasini, E.; Davies, J.; Verissimo, E.; Bachi, M. D. Angew. Chem., Int. Ed. 2004, 43, 4193. doi:10.1002/anie.200453859

103.Fattorusso, C.; Persico, M.; Calcinai, B.; Cerrano, C.; Parapini, S.; Taramelli, D.; Novellino, E.; Romano, A.; Scala, F.; Fattorusso, E.; Taglialatela-Scafati, O. J. Nat. Prod. 2010, 73, 1138. doi:10.1021/np100196b

104.Kawanishi, M.; Kotoku, N.; Itagaki, S.; Horii, T.; Kobayashi, M. Bioorg. Med. Chem. 2004, 12, 5297. doi:10.1016/j.bmc.2004.04.051

105.Taglialatela-Scafati, O.; Fattorusso, E.; Romano, A.; Scala, F.; Barone, V.; Cimino, P.; Stendardo, E.; Catalanotti, B.; Persico, M.; Fattorusso, C. Org. Biomol. Chem. 2010, 8, 846. doi:10.1039/b918600j

106. Christoffers, J.; Werner, T.; Roessle, M. Catal. Today 2007, 121, 22. doi:10.1016/j.cattod.2006.11.008

107.Bachi, M. D.; Korshin, E. E.; Hoos, R.; Szpilman, A. M.; Ploypradith, P.; Xie, S.; Shapiro, T. A.; Posner, G. H. J. Med. Chem. 2003, 46, 2516. doi:10.1021/jm020584a

108.Fattorusso, C.; Campiani, G.; Catalanotti, B.; Persico, M.; Basilico, N.; Parapini, S.; Taramelli, D.; Campagnuolo, C.; Fattorusso, E.; Romano, A. J. Med. Chem. 2006, 49, 7088. doi:10.1021/jm060899g
109. Murakami, N.; Kawanishi, M.; Itagaki, S.; Horii, T.; Kobayashi, M. Bioorg. Med. Chem. Lett. 2002, 12, 69. doi:10.1016/S0960-894X(01)00673-4

110.Murakami, N.; Kawanishi, M.; Mostaqul, H. M.; Li, J.; Itagaki, S.; Horii, T.; Kobayashi, M. Bioorg. Med. Chem. Lett. 2003, 13, 4081. doi:10.1016/j.bmcl.2003.08.073

111.Liu, H.-H.; Zhang, Q.; Jin, H.-X.; Shen, X.; Wu, Y.-K. Chin. J. Chem. 2006, 24, 1180. doi:10.1002/cjoc.200690221

112.Liu, H.-H.; Jin, H.-X.; Zhang, Q.; Wu, Y.-K.; Kim, H.-S.; Wataya, Y. Chin. J. Chem. 2005, 23, 1469. doi:10.1002/cjoc.200591469

113. Givelet, C.; Bernat, V.; Danel, M.; André-Barrès, C.; Vial, H. Eur. J. Org. Chem. 2007, 3095. doi:10.1002/ejoc.200700086 114.Rudi, A.; Talpir, R.; Kashman, Y.; Benayahu, Y.; Schleyer, M. J. Nat. Prod. 1993, 56, 2178. doi:10.1021/np50102a023

115.Ruiz, J.; Tuccio, B.; Lauricella, R.; Maynadier, M.; Vial, H.; André-Barrès, C. Tetrahedron 2013, 69, 6709. doi:10.1016/j.tet.2013.05.099

116.Kamata, M.; Hagiwara, J.-i.; Hokari, T.; Suzuki, C.; Fujino, R.; Kobayashi, S.; Kim, H.-S.; Wataya, Y. Res. Chem. Intermed. 2013, 39, 127. doi:10.1007/s11164-012-0637-3

117.Najjar, F.; Gorrichon, L.; Baltas, M.; André-Barrès, C.; Vial, H. Org. Biomol. Chem. 2005, 3, 1612. doi:10.1039/b503402g

118. Kondo, K.; Matsumoto, M.; Hatsutani, M. Patent Jpn. Kokai Tokkyo Koho JP 49061179 A, June 13, 1974.

119. Bernat, V.; Saffon, N.; Maynadier, M.; Vial, H.; André-Barrès, C. Tetrahedron 2009, 65, 7372. doi:10.1016/j.tet.2009.07.030

120.Amewu, R.; Gibbons, P.; Mukhtar, A.; Stachulski, A. V.; Ward, S. A. Hall, C.; Rimmer, K.; Davies, J.; Vivas, L.; Bacsa, J.; Mercer, A. E.; Nixon, G.; Stocks, P. A.; O'Neill, P. M. Org. Biomol. Chem. 2010, 8 , 2068. doi:10.1039/b924319d

121. Chauhan, S. S.; Sharma, M.; Chauhan, P. M. S. Drug News Perspect 2010, 23, 632. doi:10.1358/dnp.2010.23.10.1468390

122. Fernandez, I.; Robert, A. Org. Biomol. Chem. 2011, 9, 4098. doi:10.1039/c1ob05088e

123.Singh, C.; Verma, V. P.; Naikade, N. K.; Singh, A. S.; Hassam, M.; Puri, S. K. J. Med. Chem. 2008, 51, 7581. doi:10.1021/jm801006v

124. Brown, G. D. Molecules 2010, 15, 7603. doi:10.3390/molecules 15117603

125. Singh, C.; Sharma, U.; Saxena, G.; Puri, S. Bioorg. Med. Chem. Lett. 2007, 17, 4097. doi:10.1016/j.bmcl.2007.05.055

126. Singh, C.; Singh, A. S.; Naikade, N. K.; Verma, V. P.; Hassam, M.; Gupta, N.; Pandey, S. Synthesis 2010, 1014. doi:10.1055/s-0029-1218639

127. Hencken, C. P.; Kalinda, A. S.; Gaetano D'Angelo, J. Annu. Rep. Med. Chem. 2009, 44, 359. doi:10.1016/S0065-7743(09)04418-2

128.Šolaja, B. A.; Terzić, N.; Pocsfalvi, G.; Gerena, L.; Tinant, B.; Opsenica, D.; Milhous, W. K. J. Med. Chem. 2002, 45, 3331. doi:10.1021/jm020891g

129. Kirchhofer, C.; Vargas, M.; Braissant, O.; Dong, Y.; Wang, X.; Vennerstrom, J. L.; Keiser, J. Acta Trop. 2011, 118, 56. doi:10.1016/j.actatropica.2011.02.003

130. Vennerstrom, J. L.; Fu, H. N.; Ellis, W. Y.; Ager, A. L., Jr.; Wood, J. K. Andersen, S. L.; Gerena, L.; Milhous, W. K. J. Med. Chem. 1992, 35, 3023. doi:10.1021/jm00094a015

131. Hamann, H.-J.; Hecht, M.; Bunge, A.; Gogol, M.; Liebscher, J. Tetrahedron Lett. 2011, 52, 107. doi:10.1016/j.tetlet.2010.10.151 
132. Opsenica, I.; Terzić, N.; Opsenica, D.; Angelovski, G.; Lehnig, L.; Eilbracht, P.; Tinant, B.; Juranić, Z.; Smith, K. S.; Yang, Y. S.; Diaz, D. S.; Smith, P. L.; Milhous, W. K.; Doković, D.; Šolaja, B. A. J. Med. Chem. 2006, 49, 3790. doi:10.1021/jm050966r

133.Dong, Y.; McCullough, K. J.; Wittlin, S.; Chollet, J.; Vennerstrom, J. L. Bioorg. Med. Chem. Lett. 2010, 20, 6359. doi:10.1016/j.bmcl.2010.09.113

134.Cvijetic, I. N.; Zizak, Z. P.; Stanojkovic, T. P.; Juranic, Z. D.; Terzic, N.; Opsenica, I. M.; Opsenica, D. M.; Juranic, I. O.; Drakulic, B. J. Eur. J. Med. Chem. 2010, 45, 4570. doi:10.1016/j.ejmech.2010.07.019

135. Opsenica, I.; Opsenica, D.; Lanteri, C. A.; Anova, L.; Milhous, W. K.; Smith, K. S.; Solaja, B. A. J. Med. Chem. 2008, 51, 6216. doi:10.1021/jm8006905

136. Bhattacharjee, A. K.; Carvalho, K. A.; Opsenica, D.; Solaja, B. A. J. Serb. Chem. Soc. 2005, 70, 329. doi:10.2298/JSC0503329B

137. Tonmunphean, S.; Wijitkosoom, A.; Tantirungrotechai, Y. Bioorg. Med. Chem. 2004, 12, 2005. doi:10.1016/j.bmc.2004.03.003

138. Ellis, G. L.; Amewu, R.; Sabbani, S.; Stocks, P. A.; Shone, A.; Stanford, D.; Gibbons, P.; Davies, J.; Vivas, L.; Charnaud, S.; Bongard, E.; Hall, C.; Rimmer, K.; Lozanom, S.; Jesús, M.; Gargallo, D.; Ward, S. A.; O'Neill, P. M. J. Med. Chem. 2008, 51, 2170. doi:10.1021/jm701435h

139.Liu, H.-H.; Wu, Y.-K.; Shen, X. Chin. J. Chem. 2003, 21, 875. doi:10.1002/cjoc.20030210731

140.Dong, Y. Mini-Rev. Med. Chem. 2002, 2, 113.

141.Opsenica, D. M.; Terzić, N.; Smith, P. L.; Yang, Y.; Anova, L.; Smith, K. S.; Solaja, B. A. Bioorg. Med. Chem. 2008, 16, 7039. doi:10.1016/j.bmc.2008.05.017

142.Terzić, N.; Opsenica, D.; Milić, D.; Tinan, B.; Smith, K. S.; Milhous, W. K.; Šolaja, B. A. J. Med. Chem. 2007, 50, 5118. doi:10.1021/jm070684m

143.Pis Diez, R.; Jubert, A. H. J. Mol. Struct.: THEOCHEM 2000, 499, 85. doi:10.1016/S0166-1280(99)00281-X

144.Amewu, R.; Stachulski, A. V.; Ward, S. A.; Berry, N. G.; Bray, P. G.; Davies, J.; Labat, G.; Vivas, L.; O’Neill, P. M. Org. Biomol. Chem. 2006, 4, 4431. doi:10.1039/b613565j

145.Dong, Y.; Matile, H.; Chollet, J.; Kaminsky, R.; Wood, J. K.; Vennerstrom, J. L. J. Med. Chem. 1999, 42, 1477. doi:10.1021/jm980698f

146. Kumura, N.; Furukawa, H.; Kobayashi, M.; Onyango, A. N.; Izumi, M.; Nakajima, S.; Kim, H.-S.; Wataya, Y.; Baba, N. Biosci., Biotechnol., Biochem. 2009, 73, 217. doi:10.1271/bbb.80571

147.Ingram, K.; Schiaffo, C. E.; Sittiwong, W.; Benner, E.; Dussault, P. H.; Keiser, J. J. Antimicrob. Chemother. 2012, 67, 1979. doi:10.1093/jac/dks141

148.Dong, Y.; Chollet, J.; Vargas, M.; Mansour, N. R.; Bickle, Q.; Alnouti, Y.; Huang, J.; Keiser, J.; Vennerstrom, J. L. Bioorg. Med. Chem. Lett. 2010, 20, 2481. doi:10.1016/j.bmcl.2010.03.001

149.Mohamed, A. E.-H. H.; El-Sayed, M. A.; Hegazy, M. E.; Helaly, S. E.; Esmail, A. M.; Mohamed, N. S. Rec. Nat. Prod. 2010, 4, 1.

150.Yang, Z.-S.; Wu, W.-M.; Li, Y.; Wu, Y.-L. Helv. Chim. Acta 2005, 88 2865. doi:10.1002/hlca.200590229

151.Keiser, J.; Utzinger, J. Adv. Parasitol. 2010, 73, 197. doi:10.1016/S0065-308X(10)73008-6

152.Dembitsky, V.; Shkrob, I.; Hanus, L. O. Biomed. Pap. 2008, 152, 209. doi:10.5507/bp.2008.032
153.Laurent, S. A.-L.; Boissier, J.; Coslédan, F.; Gornitzka, H.; Robert, A.; Meunier, B. Eur. J. Org. Chem. 2008, 895. doi:10.1002/ejoc.200700975

154.Jung, M.; Lee, K.; Kim, H.; Park, M. Curr. Med. Chem. 2004, 11, 1265 doi:10.2174/0929867043365233

155.Xiao, S.-h.; Mei, J.-y.; Jiao, P.-y. Parasitol. Res. 2011, 108, 431. doi:10.1007/s00436-010-2084-7

156. Boissier, J.; Coslédan, F.; Robert, A.; Meunier, B. Antimicrob. Agents Chemother. 2009, 53, 4903. doi:10.1128/AAC.00640-09

157.Pradines, V.; Portela, J.; Boissier, J.; Cosledan, F.; Meunier, B.; Robert, A. Antimicrob. Agents Chemother. 2011, 55, 2403. doi:10.1128/AAC.00082-11

158. Maurya, R.; Soni, A.; Anand, D.; Ravi, M.; Raju, K. S. R.; Taneja, I.; Naikade, N. K.; Puri, S. K.; Wahajuddin, K.; Anojiya, S.; Yadav, P. P. Med. Chem. Lett. 2013, 4, 165. doi:10.1021/ml300188t

159. Ingram, K.; Yaremenko, I. A.; Krylov, I.; Hofer, L.; Terent'ev, A. O.; Keiser, J. J. Med. Chem. 2012, 55, 8700. doi:10.1021/jm3009184

160.Keiser, J.; Brun, R.; Fried, B.; Utzinger, J. Antimicrob. Agents Chemother. 2006, 50, 803. doi:10.1128/AAC.50.2.803-805.2006

161. Vennervald, B. J.; Polman, K. Parasite Immunol. 2009, 31, 686. doi:10.1111/j.1365-3024.2009.01163.x

162. Yajima, A.; Gabrielli, A. F.; Montresor, A.; Engels, D. Trans. R. Soc. Trop. Med. Hyg. 2011, 105, 68. doi:10.1016/j.trstmh.2010.11.003

163. Keiser, J.; Utzinger, J.; Tanner, M.; Dong, Y.; Vennerstrom, J. L. J. Antimicrob. Chemother. 2006, 58, 1193. doi:10.1093/jac/dkl408

164. Cooper, P. J.; Ayre, G.; Martin, C.; Rizzo, J. A.; Ponte, E. V.; Cruz, A. A. Allergy (Oxford, U. K.) 2008, 63, 409.

165.Vandemark, L. M.; Jia, T.-W.; Zhou, X.-N. Adv. Parasitol. 2010, 73, 137. doi:10.1016/S0065-308X(10)73006-2

166. Keiser, J.; Utzinger, J. Trends Parasitol. 2007, 23, 555. doi:10.1016/j.pt.2007.07.012

167.Brooker, S.; Akhwale, W.; Pullan, R.; Estambale, B.; Clarke, S. E.; Snow, R. W.; Hotez, P. J. Am. J. Trop. Med. Hyg. 2007, 77 (Suppl. 6), 88.

168.Lv, S.; Zhang, Y.; Steinmann, P.; Zhou, X.-N.; Utzinger, J. Adv. Parasitol. 2010, 72, 351. doi:10.1016/S0065-308X(10)72012-1

169.Xiao, S.-H.; Keiser, J.; Chollet, J.; Utzinger, J.; Dong, Y.; Endriss, Y.; Vennerstrom, J. L.; Tanner, M. Antimicrob. Agents Chemother. 2007, 51, 1440. doi:10.1128/AAC.01537-06

170. Cooper, P. J.; Nutman, T. B. Lung Biol. Health Dis. 2002, 164, 409.

171. Brooker, S. Int. J. Parasitol. 2010, 40, 1137. doi:10.1016/j.ijpara.2010.04.004

172.Keiser, J.; Utzinger, J. Curr. Opin. Infect. Dis. 2007, 20, 605. doi:10.1097/QCO.0b013e3282f19ec4

173. Feldmeier, H.; Chitsulo, L. Arzneim. Forsch. 1999, 49, 557.

174. Thun, M. J.; Henley, S. J.; Gansler, T. Novartis Found. Symp. 2004, 256, 6. doi:10.1002/0470856734.ch2

175. Niesen, A.; Barthel, A.; Kluge, R.; Köwitzsch, A.; Ströhl, D.; Schwarz, S.; Csuk, R. Arch. Pharm. Chem. Life Sci. 2009, 342, 569. doi:10.1002/ardp.200900051

176. Sawant, S. S.; Youssef, D. T. A.; Sylvester, P. W.; Wali, V.; El Sayed, K. A. Nat. Prod. Commun. 2007, 2, 117.

177.Csuk, R.; Niesen-Barthel, A.; Barthel, A.; Kluge, R.; Ströhl, D. Eur. J. Med. Chem. 2010, 45, 3840. doi:10.1016/j.ejmech.2010.05.036 
178.Rudi, A.; Afanii, R.; Gravalos, L. G.; Aknin, M.; Gaydou, E.; Vacelet, J.; Kashman, Y. J. Nat. Prod. 2003, 66, 682. doi:10.1021/np020589a

179.Szpilman, A. M.; Korshin, E. E.; Rozenberg, H.; Bachi, M. D. J. Org. Chem. 2005, 70, 3618. doi:10.1021/j0050074z

180.Berrue, F.; Thomas, O. P.; Funel-Le Bon, C.; Reyes, F.; Amade, P. Tetrahedron 2005, 61, 11843. doi:10.1016/j.tet.2005.09.077

181.Rudi, A.; Kashman, Y. J. Nat. Prod. 1993, 56, 1827. doi:10.1021/np50100a027

182. Yao, G.; Steliou, K. Org. Lett. 2002, 4, 485. doi:10.1021/ol016943y

183. Jung, M.; Ham, J.; Song, J. Org. Lett. 2002, 4, 2763. doi:10.1021/ol026285x

184.Wijeratne, E. M. K.; Liu, M. X.; Kantipudi, N. B.; Brochini, C. B.; Gunatilaka, A. A. L.; Canfield, L. M. Bioorg. Med. Chem. 2006, 14, 7875. doi:10.1016/j.bmc.2006.07.057

185.Aldeco-Pérez, E.; Rudler, H.; Parlier, A.; Alvarez, C.; Apan, M. T.; Herson, P.; Toscano, A. Tetrahedron Lett. 2006, 47, 9053. doi:10.1016/j.tetlet.2006.10.093

186. Dembitsky, V. M.; Gloriozova, T. A.; Poroikov, V. V. Mini-Rev. Med. Chem. 2007, 7, 571. doi:10.2174/138955707780859396

187. Hang, T. T. N.; Hu'o'ng, L. M.; Ha, T. T. H.; Ha, L. M. Tap Chi Duoc Hoc 2009, 49, 47.

188.Ma, Y.-M.; Feng, C.-L. Youji Huaxue 2008, 28, 1697.

189.Dai, J.; Liu, Y.; Zhou, Y.-D.; Nagle, D. G. J. Nat. Prod. 2007, 70, 130. doi:10.1021/np0604883

190.Rubush, D. M.; Morges, M. A.; Rose, B. J.; Thamm, D. H.; Rovis, T. J. Am. Chem. Soc. 2012, 134, 13554. doi:10.1021/ja3052427

191.Dembitsky, V. M.; Gloriozova, T. A.; Poroikov, V. V. Mini-Rev. Med. Chem. 2005, 5, 319. doi:10.2174/1389557053175362

192. Matsugo, S.; Kayamori, N.; Konishi, T. Niigata Yakka Daigaku Kenkyu Hokoku 1986, 6, 23.

193.Ryden, A.-M.; Kayser, O. Top. Heterocycl. Chem. 2007, 9, 1. doi:10.1007/7081_2007_085

194. Roshchina, V. V. Uspekhi Sovrem. Biol. 2006, 126, 366.

195. Bradley, D. Drug Discovery Today 2000, 5, 44. doi:10.1016/S1359-6446(99)01453-1

196. Jiménez, M. S.; Garznm, S. P.; Rodríguez, A. D. J. Nat. Prod. 2003, $66,655$.

197.Casteel, D. A. Nat. Prod. Rep. 1999, 16, 55. doi:10.1039/a705725c

198. Casteel, D. A. Nat. Prod. Rep. 1992, 9, 289. doi:10.1039/np9920900289

199.Lee, K. R. Saengyak Hakhoechi 1991, 22, 145.

200.Kasozi, D. M.; Rahlfs, S.; Becker, K. Drug Discovery Infect. Dis. 2011, $2,413$.

201.Denisov, E. T.; Solodova, S. L.; Denisova, T. G. Russ. Chem. Rev. 2010, 79, 981. doi:10.1070/RC2010v079n11ABEH004143

202.Davies-Coleman, M. T. Stud. Nat. Prod. Chem. 2005, 32, 61. doi:10.1016/S1572-5995(05)80054-7

203. Mancini, I.; Guella, G.; Defant, A. Mini-Rev. Med. Chem. 2008, 8 , 1265. doi:10.2174/138955708786141007

204.Lupulescu, A. Prostaglandins, Leukotrienes Essent. Fatty Acids 1996, 54, 83. doi:10.1016/S0952-3278(96)90064-2

205. Ridley, R. G.; Hudson, A. T. Curr. Opin. Infect. Dis. 1998, 11, 691. doi:10.1097/00001432-199812000-00008

206.Mohammed, R.; Peng, J.; Kelly, M.; Yousaf, M.; Winn, E.; Odde, S.; Bie, Z.; Xie, A.; Doerksen, R. J.; Hamann, M. T. Aust. J. Chem. 2010, 63, 877. doi:10.1071/CH09665
207. Camuzat-Dedenis, B.; Provot, O.; Cointeaux, L.; Perroux, V.; Berrien, J.-F.; Bories, C.; Loiseau, P. M.; Mayrargue, J. Eur. J. Med. Chem. 2001, 36, 837. doi:10.1016/S0223-5234(01)01278-8

208. Howarth, J.; Wilson, D. Bioorg. Med. Chem. Lett. 2003, 13, 2013. doi:10.1016/S0960-894X(03)00326-3

209. Van Assche, T.; Deschacht, M.; Inocencio da Luz, R. A.; Maes, L.; Cos, P. Free Radical Biol. Med. 2011, 51, 337. doi:10.1016/j.freeradbiomed.2011.05.011

210.Lim, C.-W.; Kim, Y.-K.; Jang, M. S.; Park, J.-I.; Park, H.-Y. J. Fish. Sci. Technol. 2006, 9, 175.

211. Oguri, H.; Hiruma, T.; Yamagishi, Y.; Oikawa, H.; Ishiyama, A.; Otoguro, K.; Yamada, H.; Omura, S. J. Am. Chem. Soc. 2011, 133, 7096. doi:10.1021/ja200374q

212.Feng, Y.-J.; Davis, R. A.; Sykes, M.; Avery, V. M.; Camp, D.; Quinn, R. J. J. Nat. Prod. 2010, 73, 716. doi:10.1021/np900535z

213. Macreadie, P.; Avery, T.; Greatrex, B.; Taylor, D.; Macreadie, I. Bioorg. Med. Chem. Lett. 2006, 16, 920. doi:10.1016/j.bmcl.2005.10.101

214. Manzo, E.; Ciavatta, M. L.; Melck, D.; Schupp, P.; de Voogd, N.; Gavagnin, M. J. Nat. Prod. 2009, 72, 1547. doi:10.1021/np900310j

215. Dembitsky, V. M. Tetrahedron 2003, 59, 4701. doi:10.1016/S0040-4020(03)00701-4

216.Dembitsky, V. M.; Srebnik, M. Eurasian Chem.-Technol. J. 2002, 4, 221.

217.Chen, Y.; Chilson, K.; Killday, K. B.; Harmody, D.; McCarthy, P. J.; Pomponi,, S. A.; Schimoler, R.; Selitrennikoff, C.; Wright, A. E. Cyclic peroxides as novel antifungal agents. U. S. Patent US 6521661 B1, Feb 18, 2003.

218.Avery, T. D.; Macreadie, P. I.; Greatrex, B. W.; Robinson, T. V.; Taylor, D. K.; Macreadie, I. G. Bioorg. Med. Chem. 2007, 17, 36. doi:10.1016/j.bmc.2006.10.021

219.Dembitsky, V. M.; Srebnik, M. Prog. Lipid Res. 2002, 41, 315. doi:10.1016/S0163-7827(02)00003-6

220.Fattorusso, E.; Parapini, S.; Campagnuolo, C.; Basilico, N.; Taglialatela-Scafati, O.; Taramelli, D. J. Antimicrob. Chemother. 2002, 50, 883. doi:10.1093/jac/dkg008

221. Macreadie, I. G.; Avery, T. D.; Robinson, T. V.; Macreadie, P.; Barraclough, M.; Taylor, D. K.; Tiekink, E. R. T. Tetrahedron 2008, 64, 1225. doi:10.1016/j.tet.2007.11.071

222. Kishi, M.; Maeno, K.; Natsuhara, M.; Kususe, M. Mold removal agent composition. Patent Jpn. Kokai Tokkyo Koho JP 11166196 A, June 22, 1999.

223. Gunasekera, S. P.; Gunasekera, M.; Gunawardana, G. P.; McCarthy, P.; Burres, N. J. Nat. Prod. 1990, 53, 669. doi:10.1021/np50069a021

224.Phillipson, D. W.; Rinehart, K. L., Jr. J. Am. Chem. Soc. 1983, 105, 7735. doi:10.1021/ja00364a045

225. Rugutt, J. K.; Rugutt, K. J. Nat. Prod. Lett. 2002, 16, 107. doi:10.1080/10575630290020000

226. Modi, I. A.; Ghosh, P. K.; Bhardwaj, D.; Desai, N. M.; Khamar, B. M. P38 inhibitors. PCT Int. Appl. WO 2008114119 A2, Sept 25, 2008.

227.Kyle, D. E.; Milhous, W.; Opsenica, D. M.; Pocsfalvi, G.; Solaja, B Mixed steroidal 1,2,4,5-tetraoxane compounds and methods of making and using thereof. PCT Int. Appl. WO 2003068736 A2, Aug 21, 2003.

228.Chen, L.-W.; Cheng, M.-J.; Peng, C.-F.; Chen, I.-S. Chem. Biodiversity 2010, 7, 1814. doi:10.1002/cbdv.200900227

229. Stratakis, M.; Orfanopoulos, M. Tetrahedron 2000, 56, 1595. doi:10.1016/S0040-4020(99)00950-3 
230.Clennan, E. L.; Pace, A. Tetrahedron 2005, 61, 6665. doi:10.1016/j.tet.2005.04.017

231.Frimer, A. A.; Afri, M.; Baumel, S. D.; Gilinsky-Sharon, P.; Rosenthal, Z.; Gottlieb, H. E. J. Org. Chem. 2000, 65, 1807. doi:10.1021/jo991803b

232. Cointeaux, L.; Berrien, J.-F.; Mayrargue, J. Tetrahedron Lett. 2002, 43, 6275. doi:10.1016/S0040-4039(02)01122-X

233.Adam, W.; Peters, K.; Peters, E.-M.; Schambony, S. J. Am. Chem. Soc. 2000, 122, 7610. doi:10.1021/ja001113।

234.Barnier, J.-P.; Morisson, V.; Blanco, L. Synth. Commun. 2001, 31, 349. doi:10.1081/SCC-100000523

235. Kirihara, M.; Kakuda, H.; Ichinose, M.; Ochiai, Y.; Takizawa, S.; Mokuya, A.; Okubo, K.; Hatano, A.; Shiro, M. Tetrahedron 2005, 61, 4831. doi:10.1016/j.tet.2005.03.033

236. Kulinkovich, O. G.; Astashko, D. A.; Tyvorskii, V. I.; Ilyina, N. A. Synthesis 2001, 1453. doi:10.1055/s-2001-16089

237. Wimalasena, K.; Wickman, H. B.; Mahindaratne, M. P. D. Eur. J. Org. Chem. 2001, 3811. doi:10.1002/1099-0690(200110)2001:20<3811::AID-EJOC3811>3.0.C 0;2-6

238. Ouhamou, N.; Six, Y. Org. Biomol. Chem. 2003, 1, 3007. doi:10.1039/b306719j

239. Madelaine, C.; Buzas, A. K.; Kowalska-Six, J. A.; Six, Y.; Crousse, B. Tetrahedron Lett. 2009, 50, 5367. doi:10.1016/j.tetlet.2009.07.031

240.Zhao, Q.; Wong, H. N. C. Tetrahedron 2007, 63, 6296. doi:10.1016/j.tet.2007.02.121

241.Ikeda, H.; Akiyama, K.; Takahashi, Y.; Nakamura, T.; Ishizaki, S.; Shiratori, Y.; Ohaku, H.; Goodman, J. L.; Houmam, A.; Wayner, D. D. M.; Tero-Kubota, S.; Miyashi, T. J. Am. Chem. Soc. 2003, 125, 9147. doi:10.1021/ja0277982

242. Ikeda, H.; Hoshi, Y.; Miyashi, T. Tetrahedron Lett. 2001, 42, 8485. doi:10.1016/S0040-4039(01)01786-5

243.Abe, M.; Kawanami, S.; Masuyama, A.; Hayashi, T. J. Org. Chem. 2006, 71, 6607. doi:10.1021/jo060587।

244.Gbur, R. K.; Little, R. D. J. Org. Chem. 2012, 77, 2134-2141. doi:10.1021/jo300297u

245. Tsubusaki, T.; Nishino, H. Tetrahedron 2009, 65, 3745. doi:10.1016/j.tet.2009.02.045

246. Isayama, S.; Mukaiyama, T. Chem. Lett. 1989, 573. doi:10.1246/cl.1989.573

247.Isayama, S. Bull. Chem. Soc. Jpn. 1990, 63, 1305. doi:10.1246/bcsj.63.1305

248. Tokuyasu, T.; Kunikawa, S.; Masuyama, A.; Nojima, M. Org. Lett. 2002, 4, 3595. doi:10.1021/ol0201299

249. Tokuyasu, T.; Kunikawa, S.; McCullough, K. J.; Masuyama, A.; Nojima, M. J. Org. Chem. 2005, 70, 251. doi:10.1021/jo048359j

250.Dai, P.; Dussault, P. H. Org. Lett. 2005, 7, 4333. doi:10.1021/ol051407h

251.Barnych, B.; Vatèle, J.-M. Tetrahedron 2012, 68, 3717. doi:10.1016/j.tet.2012.03.024

252.Ghorai, P.; Dussault, P. H.; Hu, C. Org. Lett. 2008, 10, 2401. doi:10.1021/ol800657m

253.Kumar, D. N.; Sudhakar, N.; Rao, B. V.; Kishore, K. H.; Murty, U. S. Tetrahedron Lett. 2006, 47, 771. doi:10.1016/j.tetlet.2005.11.107

254. Hamann, H.-J.; Wlosnewski, A.; Greco, T.; Liebscher, J. Eur. J. Org. Chem. 2006, 2174. doi:10.1002/ejoc.200500803

255.Stewart, S. G.; Ghisalberti, E. L.; Skelton, B. W.; Heath, C. H. Org. Biomol. Chem. 2010, 8, 3563. doi:10.1039/c003742g

256. Dussault, P. H.; Lee, H.-J.; Liu, X. J. Chem. Soc., Perkin Trans. 1 2000, 3006. doi:10.1039/B001391I
257.Dussault, P. H.; Lee, I. Q.; Lee, H.-J.; Lee, R. J.; Niu, Q. J.; Schultz, J. A.; Zope, U. R. J. Org. Chem. 2000, 65, 8407. doi:10.1021/jo991714z

258.Zhao, Q.; Vargas, M.; Dong, Y.; Zhou, L.; Wang, X.; Sriraghavan, K.; Keiser, J.; Vennerstrom, J. L. J. Med. Chem. 2010, 53, 4223. doi:10.1021/jm100226t

259. Ramirez, A.; Woerpel, K. A. Org. Lett. 2005, 7, 4617. doi:10.1021/ol051703u

260. Dai, P.; Trullinger, T. K.; Liu, X.; Dussault, P. H. J. Org. Chem. 2006, 71, 2283. doi:10.1021/jo0522254

261.Lu, X.; Liu, Y.; Sun, B.; Cindric, B.; Deng, L. J. Am. Chem. Soc. 2008, 130, 8134. doi:10.1021/ja802982h

262. Reisinger, C. M.; Wang, X.; List, B. Angew. Chem., Int. Ed. 2008, 47, 8112. doi:10.1002/anie.200803238

263. Silva, E. M. P.; Pye, R. J.; Brown, G. D.; Harwood, L. M. Eur. J. Org. Chem. 2012, 1209. doi:10.1002/ejoc.201101477

264. Guerra, F. M.; Zubia, E.; Ortega, M. J.; Moreno-Dorado, F. J.; Massanet, G. M. Tetrahedron 2010, 66, 157. doi:10.1016/j.tet.2009.11.026

265.Singh, C.; Srivastav, N. C.; Srivastava, N.; Puri, S. K. Tetrahedron Lett. 2005, 46, 2757. doi:10.1016/j.tetlet.2005.02.158

266. Kishali, N.; Sahin, E.; Kara, Y. Org. Lett. 2006, 8, 1791. doi:10.1021/ol060272s

267.Dussault, P. H.; Xu, C. Tetrahedron Lett. 2004, 45, 7455. doi:10.1016/j.tetlet.2004.08.059

268. Criegee, R. Angew. Chem., Int. Ed. Engl. 1975, 87, 745. doi:10.1002/anie.197507451

269. Geletneky, C.; Berger, S. Eur. J. Org. Chem. 1998, 1625. doi:10.1002/(SICI)1099-0690(199808)1998:8<1625::AID-EJOC1625> 3.0.CO;2-L

270. Tokuyasu, T.; Ito, T.; Masuyama, A.; Nojima, M. Heterocycles 2000, 53, 1293. doi:10.3987/COM-00-8874

271.Nicolaou, K. C.; Rodriguez, R. M.; Mitchell, H. J.; Suzuki, H.; Fylaktakidou, K. C.; Baudoin, O.; van Delft, F. L. Chem.-Eur. J. 2000, 6, 3095.

doi:10.1002/1521-3765(20000901)6:17<3095::AID-CHEM3095>3.0.C $0 ; 2-4$

272.Hon, Y.-S.; Lu, L.; Chang, R.-C.; Lin, S.-W.; Sun, P.-P.; Lee, C.-F. Tetrahedron 2000, 56, 9269. doi:10.1016/S0040-4020(00)00903-0

273. Odinokov, V. N.; Akhmetova, V. R.; Savchenko, R. G.; Bazunova, M. V.; Paramonov, E. A.; Khalilov, L. M. Russ. Chem. Bull. 2000, 49, 1103. doi:10.1007/BF02494903

274. Odinokov, V. N.; Akhmetova, V. R.; Bazunova, M. V.; Savchenko, R. G.; Paramonov, E. A.; Khalilov, L. M. Russ. J. Org. Chem. 2001, 37, 321. doi:10.1023/A:1012311903712

275.Dussault, P. H.; Raible, J. M. Org. Lett. 2000, 2, 3377. doi:10.1021/ol006478p

276. Jung, I. C. Eur. J. Org. Chem. 2001, 1899. doi:10.1002/1099-0690(200105)2001:10<1899::AID-EJOC1899>3.0.C O;2-L

277. Caronna, T.; Gabbiadini, S.; Mele, A.; Recupero, F. Helv. Chim. Acta 2002, 85, 1. doi:10.1002/1522-2675(200201)85:1<1::AID-HLCA1>3.0.CO;2-C

278. Kiryukhin, D. P.; Barkalov, I. M.; Ismoilov, I. L. Russ. J. Appl. Chem. 2001, 74, 1740. doi:10.1023/A:1014829924249

279. Chen, L.; Wiemer, D. F. J. Org. Chem. 2002, 67, 7561. doi:10.1021/jo020362k

280.Rücker, G.; Manns, D.; Schenkel, E. P.; Hartmann, R.; Heinzmann, B. M. Arch. Pharm. Pharm. Med. Chem. 2003, 336, 205. doi:10.1002/ardp.200300740 
281. Hitchcock, P. B.; Papadopoulos, K.; Young, D. W. Org. Biomol. Chem. 2003, 1, 2670. doi:10.1039/b304607a

282.Wattanasereekul, S.; Maier, M. E. Adv. Synth. Catal. 2004, 346, 855. doi:10.1002/adsc.200404004

283.Schank, K.; Beck, H.; Pistorius, S. Helv. Chim. Acta 2004, 87, 2025. doi:10.1002/hlca.200490182

284.Laventine, D. M.; Davies, M.; Evinson, E. L.; Jenkins, P. R.; Cullis, P. M.; Fawcett, J. Tetrahedron Lett. 2005, 46, 307. doi:10.1016/j.tetlet.2004.11.032

285.Laventine, D. M.; Davies, M.; Evinson, E. L.; Jenkins, P. R.; Cullis, P. M.; Garcia, M. D. Tetrahedron 2009, 65, 4766. doi:10.1016/j.tet.2009.04.011

286.Wang, C.; Liu, J.; Ji, Y.; Zhao, J.; Li, L.; Zhang, H. Org. Lett. 2006, 8, 2479. doi:10.1021/ol060382z

287.Schwartz, C.; Raible, J.; Mott, K.; Dussault, P. H. Org. Lett. 2006, 8, 3199. doi:10.1021/ol061001k

288.Schwartz, C.; Raible, J.; Mott, K.; Dussault, P. H. Tetrahedron 2006, 62, 10747. doi:10.1016/j.tet.2006.08.092

289.Schiaffo, C. E.; Dussault, P. H. J. Org. Chem. 2008, 73, 4688. doi:10.1021/j0800323x

290.Percy, J. M.; Roig, R.; Singh, K. Eur. J. Org. Chem. 2009, 1058. doi:10.1002/ejoc. 200801130

291.Shin, H. S.; Lee, C.; Lee, J. Y.; Huh, T. S. Eur. J. Org. Chem. 2000, 335. doi:10.1002/(SICI)1099-0690(200001)2000:2<335::AID-EJOC335>3.0 .CO;2-2

292.Park, S. H.; Lee, J. Y.; Huh, T. S. Eur. J. Org. Chem. 2001, 3083. doi:10.1002/1099-0690(200108)2001:16<3083::AID-EJOC3083>3.0.C O;2-K

293.Kawamura, S.-i.; Yamakoshi, H.; Abe, M.; Masuyama, A.; Nojima, M. Tetrahedron 2002, 58, 891. doi:10.1016/S0040-4020(01)01183-8

294.Griesbaum, K.; Frank, A.; McCullough, K. J. Eur. J. Org. Chem. 2006, 1978. doi:10.1002/ejoc.200500806

295.Griesbaum, K.; Bikem, Ö.; Huh, T. S.; Dong, Y. Liebigs Ann. 1995, 1571. doi:10.1002/jlac.1995199508217

296.Araújo, N. C. P.; Barton, V.; Jones, M.; Stocks, P. A.; Ward, S. A.; Davies, J.; Bray, P. G.; Shone, A. E.; Cristiano, M. L. S.; O’Neill, P. M. Bioorg. Med. Chem. Lett. 2009, 19, 2038. doi:10.1016/j.bmcl.2009.02.013

297.Tang, Y.; Dong, Y.; Karle, J. M.; DiTusa, C. A.; Vennerstrom, J. L. J. Org. Chem. 2004, 69, 6470. doi:10.1021/jo040171c

298.Zhou, L.; Alker, A.; Ruf, A.; Wang, X.; Chiu, F. C. K.; Morizzi, J.; Charman, S. A.; Charman, W. N.; Scheurer, C.; Wittlin, S.; Dong, Y.; Hunziker, D.; Vennerstrom, J. L. Bioorg. Med. Chem. Lett. 2008, 18, 1555. doi:10.1016/j.bmcl.2008.01.087

299. Kamata, M.; Komatsu, K.-i.; Akaba, R. Tetrahedron Lett. 2001, 42, 9203. doi:10.1016/S0040-4039(01)01972-4

300.Li, Y.; Hao, H.-D.; Zhang, Q.; Wu, Y. Org. Lett. 2009, 11, 1615. doi:10.1021/ol900262t

301.Kamata, M.; Ohta, M.; Komatsu, K.-i.; Kim, H.-S.; Wataya, Y. Tetrahedron Lett. 2002, 43, 2063. doi:10.1016/S0040-4039(02)00166-1

302.Parrish, J. D.; Ischay, M. A.; Lu, Z.; Guo, S.; Peters, N. R.; Yoon, T. P. Org. Lett. 2012, 14, 1640. doi:10.1021/ol300428q

303. La Clair, J. J. Angew. Chem., Int. Ed. 2006, 45, 2769. doi:10.1002/anie.200504033

304.Griesbeck, A. G.; Cho, M. Tetrahedron Lett. 2009, 50, 121. doi:10.1016/j.tetlet.2008.10.094

305. Iwahama, T.; Sakaguchi, S.; Ishii, Y. Chem. Commun. 2000, 2317. doi:10.1039/b007182j
306. Kumabe, R.; Nishino, H.; Yasutake, M.; Nguyen, V.-H.; Kurosawa, K. Tetrahedron Lett. 2001, 42, 69. doi:10.1016/S0040-4039(00)01884-0

307.Christoffers, J.; Werner, T.; Frey, W.; Baro, A. Eur. J. Org. Chem. 2003, 4879. doi:10.1002/ejoc.200300439

308. Rössle, M.; Werner, T.; Frey, W.; Christoffers, J. Eur. J. Org. Chem. 2005, 5031. doi:10.1002/ejoc.200500487

309. Kumabe, R.; Nishino, H. Tetrahedron Lett. 2004, 45, 703. doi:10.1016/j.tetlet.2003.11.054

310.Asahi, K.; Nishino, H. Tetrahedron 2005, 61, 11107. doi:10.1016/j.tet.2005.09.029

311.Asahi, K.; Nishino, H. Tetrahedron 2008, 64, 1620. doi:10.1016/j.tet.2007.12.017

312. Asahi, K.; Nishino, H. Eur. J. Org. Chem. 2008, 2404 doi:10.1002/ejoc.200701232

313.Beckwith, A. L. J.; Wagner, R. D. J. Am. Chem. Soc. 1979, 101, 7099. doi:10.1021/ja00517a069

314.Beckwith, A. L. J.; Wagner, R. D. J. Chem. Soc., Chem. Commun. 1980, 485. doi:10.1039/C39800000485

315.Korshin, E. E.; Hoos, R.; Szpilman, A. M.; Konstantinovski, L.; Posner, G. H.; Bachi, M. D. Tetrahedron 2002, 58, 2449. doi:10.1016/S0040-4020(02)00126-6

316. O'Neill, P. M.; Verissimo, E.; Ward, S. A.; Davies, J.; Korshin, E. E.; Araujo, N.; Pugh, M. D.; Cristiano, M. L. S.; Stocks, P. A.; Bachi, M. D. Bioorg. Med. Chem. Lett. 2006, 16, 2991. doi:10.1016/j.bmcl.2006.02.059

317.Kim, J.; Li, H. B.; Rosenthal, A. S.; Sang, D.; Shapiro, T. A.; Bachi, M. D.; Posner, G. H. Tetrahedron 2006, 62, 4120. doi:10.1016/j.tet.2006.02.008

318. Tokuyasu, T.; Kunikawa, S.; Abe, M.; Masuyama, A.; Nojima, M.; Kim, H.-S.; Begum, K.; Wataya, Y. J. Org. Chem. 2003, 68, 7361. doi:10.1021/jo030107f

319.Wu, J.-M.; Kunikawa, S.; Tokuyasu, T.; Masuyama, A.; Nojima, M.; Kim, H.-S.; Wataya, Y. Tetrahedron 2005, 61, 9961. doi:10.1016/j.tet.2005.08.025

320.Gemma, S.; Martí, F.; Gabellieri, E.; Campiani, G.; Novellino, E.; Butini, S. Tetrahedron Lett. 2009, 50, 5719. doi:10.1016/j.tetlet.2009.07.137

321. Gemma, S.; Gabellieri, E.; Coccone, S. S.; Martí, F.; Taglialatela-Scafati, O.; Novellino, E.; Campiani, G.; Butini, S. J. Org. Chem. 2010, 75, 2333. doi:10.1021/j01001559

322. Murakami, N.; Kawanishi, M.; Itagaki, S.; Horii, T.; Kobayashi, M. Tetrahedron Lett. 2001, 42, 7281. doi:10.1016/S0040-4039(01)01493-9

323. Murakami, N.; Kawanishi, M.; Itagaki, S.; Horii, T.; Kobayashi, M. Bioorg. Med. Chem. Lett. 2002, 12, 69. doi:10.1016/S0960-894X(01)00673-4

324. Murakami, N.; Kawanishi, M.; Itagaki, S.; Horii, T.; Kobayashi, M. Bioorg. Med. Chem. Lett. 2004, 14, 3513. doi:10.1016/j.bmcl.2004.04.086

325.Jin, H.-X.; Liu, H.-H.; Zhang, Q.; Wu, Y. Tetrahedron Lett. 2005, 46, 5767. doi:10.1016/j.tetlet.2005.06.110

326. Jin, H.-X.; Zhang, Q.; Kim, H.-S.; Wataya, Y.; Liu, H.-H.; Wu, Y. Tetrahedron 2006, 62, 7699. doi:10.1016/j.tet.2006.05.065

327.Jin, H.-X.; Liu, H.-H.; Zhang, Q.; Wu, Y. J. Org. Chem. 2005, 70, 4240. doi:10.1021/jo050139y

328. Li, Y.; Zhang, Q.; Wittlin, S.; Jin, H.-X.; Wu, Y. Tetrahedron 2009, 65, 6972. doi:10.1016/j.tet.2009.06.050

329.Xu, C.; Raible, J. M.; Dussault, P. H. Org. Lett. 2005, 7, 2509. doi:10.1021/ol050291m 
330.Fontana, A.; d'Ippolito, G.; D'Souza, L.; Mollo, E.; Parameswaram, P. S.; Cimino, G. J. Nat. Prod. 2001, 64, 131. doi:10.1021/np0002435

331.Zhang, Q.; Li, Y.; Wu, Y.-K. Chin. J. Chem. 2007, 25, 1304. doi:10.1002/cjoc.200790242

332.Xu, C.; Schwartz, C.; Raible, J.; Dussault, P. H. Tetrahedron 2009, 65, 9680. doi:10.1016/j.tet.2009.09.068

333. Tokuyasu, T.; Masuyama, A.; Nojima, M.; McCullough, K. J. J. Org. Chem. 2000, 65, 1069. doi:10.1021/jo991499m

334.Tokuyasu, T.; Masuyama, A.; Nojima, M.; Kim, H.-S.; Wataya, Y. Tetrahedron Lett. 2000, 41, 3145. doi:10.1016/S0040-4039(00)00372-5

335.Kim, H.-S.; Begum, K.; Ogura, N.; Wataya, Y.; Tokuyasu, T.; Masuyama, A.; Nojima, M.; McCullough, K. J. J. Med. Chem. 2002, 45, 4732. doi:10.1021/jm020208q

336. Harris, J. R.; Waetzig, S. R.; Woerpel, K. A. Org. Lett. 2009, 11, 3290. doi:10.1021/ol901046z

337. O’Neill, P. M.; Rawe, S. L.; Storr, R. C.; Ward, S. A.; Posner, G. H. Tetrahedron Lett. 2005, 46, 3029. doi:10.1016/j.tetlet.2005.03.022

338. Tokuyasu, T.; Masuyama, A.; Nojima, M.; McCullough, K. J.; Kim, H.-S.; Wataya, Y. Tetrahedron 2001, 57, 5979. doi:10.1016/S0040-4020(01)00557-9

339.Rostami, A.; Wang, Y.; Arif, A. M.; McDonald, R.; West, F. G. Org. Lett. 2007, 9, 703. doi:10.1021/ol070053m

340. Matsumoto, M.; Nasu, S.; Takeda, M.; Murakami, H.; Watanabe, N. Chem. Commun. 2000, 821. doi:10.1039/b002161j

341.López, D.; Quiñoá, E.; Riguera, R. J. Org. Chem. 2000, 65, 4671. doi:10.1021/jo000288a

342. Takabatake, T.; Miyazawa, T.; Hasegawa, M.; Foote, C. S. Tetrahedron Lett. 2001, 42, 987. doi:10.1016/S0040-4039(00)02216-4

343. Özen, R.; Kormalı, F.; Balci, M.; Atasoy, B. Tetrahedron 2001, 57, 7529. doi:10.1016/S0040-4020(01)00702-5

344.Daştan, A.; Saracoglu, N.; Balci, M. Eur. J. Org. Chem. 2001, 3519. doi:10.1002/1099-0690(200109)2001:18<3519::AID-EJOC3519>3.0.C O;2-2

345.Güney, M.; Daştan, A.; Balci, M. Helv. Chim. Acta 2005, 88, 830. doi:10.1002/hlca.200590061

346. Daştan, A.; Balci, M. Tetrahedron 2006, 62, 4003. doi:10.1016/j.tet.2006.02.026

347.Güney, M.; Ceylan, Z. C.; Daştan, A.; Balci, M. Can. J. Chem. 2005, 83, 227. doi:10.1139/v05-046

348.Gu, X.; Zhang, W.; Salomon, R. G. J. Am. Chem. Soc. 2007, 129, 6088. doi:10.1021/ja0689785

349.Blay, G.; Garcia, B.; Molina, E.; Pedro, J. R. Org. Lett. 2005, 7, 3291. doi:10.1021/ol0511023

350.Yang, Y.-K.; Lee, S.; Tae, J. Bull. Korean Chem. Soc. 2004, 25, 1307. doi:10.5012/bkcs.2004.25.9.1307

351.Yang, Y.-K.; Choi, J.-H.; Tae, J. J. Org. Chem. 2005, 70, 6995. doi:10.1021/jo050957q

352.Avery, T. D.; Caiazza, D.; Culbert, J. A.; Taylor, D. K.; Tiekink, E. R. T. J. Org. Chem. 2005, 70, 8344. doi:10.1021/j0050806n

353.Van der Westhuyzen, C. W.; Parkinson, C. J. S. Afr. J. Chem. 2005, $58,41$.

354. Valente, P.; Avery, T. D.; Taylor, D. K.; Tiekink, E. R. T. J. Org. Chem. 2009, 74, 274. doi:10.1021/jo8020506

355.Kao, T.-C.; Chuang, G. J.; Liao, C.-C. Angew. Chem., Int. Ed. 2008, 120, 7435-7437. doi:10.1002/anie.200802130

356.Robinson, T. V.; Pedersen, D. S.; Taylor, D. K.; Tiekink, E. R. T. J. Org. Chem. 2009, 74, 5093-5096. doi:10.1021/jo900669u
357.Schobert, R.; Siegfried, S.; Weingärtner, J.; Nieuwenhuyzen, M. J. Chem. Soc., Perkin Trans. 1 2001, 2009. doi:10.1039/B104227K 358.Schobert, R.; Stehle, R.; Milius, W. J. Org. Chem. 2003, 68, 9827. doi:10.1021/jo030270a

359. Gavrilan, M.; André-Barrès, C.; Baltas, M.; Tzedakis, T.; Gorrichon, L. Tetrahedron Lett. 2001, 42, 2465. doi:10.1016/S0040-4039(01)00199-X

360.Najjar, F.; Baltas, M.; Gorrichon, L.; Moreno, Y.; Tzedakis, T.; Vial, H.; André-Barrès, C. Eur. J. Org. Chem. 2003, 3335. doi:10.1002/ejoc.200300165

361. Çetin, F.; Yenil, N.; Yüceer, L. Carbohydr. Res. 2005, 340, 2583. doi:10.1016/j.carres.2005.09.006

362. Margaros, I.; Montagnon, T.; Vassilikogiannakis, G. Org. Lett. 2007, 9, 5585. doi:10.1021/ol702575a

363.Zvarec, O.; Avery, T. D.; Taylor, D. K. J. Org. Chem. 2010, 75, 450. doi:10.1021/jo902290g

364.Zvarec, O.; Avery, T. D.; Taylor, D. K.; Tiekink, E. R. T. Tetrahedron 2010, 66, 1007. doi:10.1016/j.tet.2009.11.068

365. Robinson, T. V.; Taylor, D. K.; Tiekink, E. R. T. J. Org. Chem. 2006, 71, 7236. doi:10.1021/jo060949p

366. Taylor, D. K.; Avery, T. D.; Greatrex, B. W.; Tiekink, E. R. T.; Macreadie, I. G.; Macreadie, P. I.; Humphries, A. D.; Kalkanidis, M.; Fox, E. N.; Klonis, N.; Tilley, L. J. Med. Chem. 2004, 47, 1833. doi:10.1021/jm0305319

367.del Pilar Crespo, M.; Avery, T. D.; Hanssen, E.; Fox, E.; Robinson, T. V.; Valente, P.; Taylor, D. K.; Tilley, L. Antimicrob. Agents Chemother. 2008, 52, 98. doi:10.1128/AAC.00609-07

368. Emerzian, M. A.; Davenport, W.; Song, J.; Li, J.; Erden, I. Adv. Synth. Catal. 2009, 351, 999. doi:10.1002/adsc.200800804

369. Özer, G.; Saraçoğlu, N.; Balci, M. J. Org. Chem. 2003, 68, 7009. doi:10.1021/j00345300

370.Singh, C. Tetrahedron Lett. 1990, 31, 6901. doi:10.1016/S0040-4039(00)97202-2

371. Griesbeck, A. G.; El-Idreesy, T. T.; Fiege, M.; Brun, R. Org. Lett. 2002, 4, 4193. doi:10.1021/ol026916n

372.Singh, C.; Gupta, N.; Puri, S. K. Bioorg. Med. Chem. Lett. 2003, 13, 3447. doi:10.1016/S0960-894X(03)00782-0

373.Singh, C.; Gupta, N.; Puri, S. K. Bioorg. Med. Chem. Lett. 2002, 12, 1913. doi:10.1016/S0960-894X(02)00320-7

374.Singh, C.; Malik, H.; Puri, S. K. Bioorg. Med. Chem. Lett. 2004, 14, 459. doi:10.1016/j.bmcl.2003.10.051

375.Singh, C.; Malik, H.; Puri, S. K. Bioorg. Med. Chem. Lett. 2005, 15 , 4484. doi:10.1016/j.bmcl.2005.07.013

376.Singh, C.; Malik, H. Org. Lett. 2005, 7, 5673. doi:10.1021/ol052378d

377.Singh, C.; Malik, H.; Puri, S. K. Bioorg. Med. Chem. 2004, 12, 1177. doi:10.1016/j.bmc.2003.11.021

378.Singh, C.; Kanchan, R.; Srivastava, N. C.; Puri, S. K. Bioorg. Med. Chem. Lett. 2006, 16, 584. doi:10.1016/j.bmcl.2005.10.044

379.Singh, C.; Malik, H.; Puri, S. K. J. Med. Chem. 2006, 49, 2794. doi:10.1021/jm051130r

380.Singh, C.; Verma, V. P.; Naikade, N. K.; Singh, A. S.; Hassam, M.; Puri, S. K. Bioorg. Med. Chem. Lett. 2010, 20, 4459. doi:10.1016/j.bmcl.2010.06.045

381. Singh, C.; Gupta, N.; Puri, S. K. Bioorg. Med. Chem. 2004, 12, 5553. doi:10.1016/j.bmc.2004.08.005

382.Singh, C.; Gupta, N.; Puri, S. K. Tetrahedron Lett. 2005, 46, 205. doi:10.1016/j.tetlet.2004.11.078 
383.Singh, C.; Srivastava, N. C.; Puri, S. K. Bioorg. Med. Chem. 2004, 12, 5745. doi:10.1016/j.bmc.2004.08.042

384.Griesbeck, A. G.; El-Idreesy, T. T.; Höinck, L.-O.; Lex, J.; Brun, R. Bioorg. Med. Chem. Lett. 2005, 15, 595. doi:10.1016/j.bmcl.2004.11.043

385.Bartoschek, A.; El-Idreesy, T. T.; Griesbeck, A. G.; Höinck, L.-O.; Lex, J.; Miara, C.; Neudörfl, J. M. Synthesis 2005, 2433. doi:10.1055/s-2005-872103

386. Griesbeck, A. G.; El-Idreesy, T. T.; Lex, J. Tetrahedron 2006, 62, 10615. doi:10.1016/j.tet.2006.05.093

387.Sabbani, S.; La Pensée, L.; Bacsa, J.; Hedenström, E.; O’Neill, P. M. Tetrahedron 2009, 65, 8531. doi:10.1016/j.tet.2009.08.020

388. Griesbeck, A. G.; Höinck, L.-O.; Neudörfl, J. M. Beilstein J. Org. Chem. 2010, 6, No. 61. doi:10.3762/bjoc.6.61

389.Griesbeck, A. G.; Höinck, L.-O.; Lex, J.; Neudörfl, J.; Blunk, D.; El-Idreesy, T. T. Molecules 2008, 13, 1743. doi:10.3390/molecules13081743

390.Singh, C.; Kanchan, R.; Sharma, U.; Puri, S. K. J. Med. Chem. 2007, 50, 521. doi:10.1021/jm0610043

391.Griesbeck, A. G.; Blunk, D.; El-Idreesy, T. T.; Raabe, A. Angew. Chem., Int. Ed. 2007, 46, 8883. doi:10.1002/anie.200701397

392. Griesbeck, A. G.; Raabe, A. Synlett 2009, 1514. doi:10.1055/s-0029-1216740

393. O'Neill, P. M.; Mukhtar, A.; Ward, S. A.; Bickley, J. F.; Davies, J.; Bachi, M. D.; Stocks, P. A. Org. Lett. 2004, 6, 3035. doi:10.1021/ol0492142

394.Jefford, C. W.; Velarde, J. A.; Bernardinelli, G.; Bray, D. H.; Warhurst, D. C.; Milhous, W. K. Helv. Chim. Acta 1993, 76, 2775. doi:10.1002/hlca.19930760804

395.Posner, G. H.; Maxwell, J. P.; O'Dowd, H.; Krasavin, M.; Xie, S.; Shapiro, T. A. Bioorg. Med. Chem. 2000, 8, 1361. doi:10.1016/S0968-0896(00)00079-1

396.Posner, G. H.; Jeon, H. B.; Parker, M. H.; Krasavin, M.; Paik, I.-H.; Shapiro, T. A. J. Med. Chem. 2001, 44, 3054. doi:10.1021/jm0102396

397.Posner, G. H.; Jeon, H. B.; Ploypradith, P.; Paik, I.-H.; Borstnik, K.; Xie, S.; Shapiro, T. A. J. Med. Chem. 2002, 45, 3824. doi:10.1021/jm020210h

398.Dechy-Cabaret, O.; Benoit-Vical, F.; Loup, C.; Robert, A.; Gornitzka, H.; Bonhoure, A.; Vial, H.; Magnaval, J.-F.; Séguéla, J.-P.; Meunier, B. Chem.-Eur. J. 2004, 10, 1625 doi:10.1002/chem.200305576

399.Singh, R.; Ishar, M. P. S. Tetrahedron Lett. 2003, 44, 1943. doi:10.1016/S0040-4039(03)00086-8

400. Cole, K. P.; Hsung, R. P. Chem. Commun. 2005, 5784. doi:10.1039/b511338e

401.Tang, Y.; Cole, K. P.; Buchanan, G. S.; Li, G.; Hsung, R. P. Org. Lett. 2009, 11, 1591. doi:10.1021/ol900237e

402.Borsarelli, C. D.; Mischne, M.; La Venia, A.; Morán Vieyra, F. E. Photochem. Photobiol. 2007, 83, 1313. doi:10.1111/j.1751-1097.2007.00147.x

403. O’Neil, P. M.; Pugh, M.; Davies, J.; Ward, S. A.; Park, B. K. Tetrahedron Lett. 2001, 42, 4569. doi:10.1016/S0040-4039(01)00791-2

404.O'Neill, P. M.; Hindley, S.; Pugh, M. D.; Davies, J.; Bray, P. G.; Park, B. K.; Kapu, D. S.; Ward, S. A.; Stocks, P. A. Tetrahedron Lett. 2003, 44, 8135. doi:10.1016/j.tetlet.2003.09.033

405.Tang, Y.; Dong, Y.; Wang, X.; Sriraghavan, K.; Wood, J. K.; Vennerstrom, J. L. J. Org. Chem. 2005, 70, 5103. doi:10.1021/j0050385+
406. Erhardt, S.; Macgregor, S. A.; McCullough, K. J.; Savill, K.; Taylor, B. J. Org. Lett. 2007, 9, 5569. doi:10.1021/ol702534d 407.Sabbani, S.; Stocks, P. A.; Ellis, G. L.; Davies, J.; Hedenstrom, E.; Ward, S. A.; O'Neill, P. M. Bioorg. Med. Chem. Lett. 2008, 18, 5804. doi:10.1016/j.bmcl.2008.09.052

408. Ramirez, A. P.; Thomas, A. M.; Woerpel, K. A. Org. Lett. 2009, 11, 507. doi:10.1021/ol8022853

409.Zhang, Q.; Jin, H.-X.; Wu, Y. Tetrahedron 2006, 62, 11627. doi:10.1016/j.tet.2006.09.061

410.Zhang, Q.; Wu, Y. Tetrahedron 2007, 63, 10189. doi:10.1016/j.tet.2007.07.090

411. Riveira, M. J.; La-Venia, A.; Mischne, M. P. Tetrahedron Lett. 2010, 51, 804. doi:10.1016/j.tetlet.2009.11.135

412.Bellot, F.; Coslédan, F.; Vendier, L.; Brocard, J.; Meunier, B.; Robert, A. J. Med. Chem. 2010, 53, 4103. doi:10.1021/jm100117e

413. Vennerstrom, J. L.; Dong, Y.; Andersen, S. L.; Ager, A. L.; Fu, H.; Miller, R. E.; Wesche, D. L.; Kyle, D. E.; Gerena, L.; Walters, S. M.; Wood, J. K.; Edwards, G.; Holme, A. D.; McLean, W. G.; Milhous, W. K. J. Med. Chem. 2000, 43, 2753. doi:10.1021/jm0000766

414. McCullough, K. J.; Wood, J. K.; Bhattacharjee, A. K.; Dong, Y.; Kyle, D. E.; Milhous, W. K.; Vennerstrom, J. L. J. Med. Chem. 2000, 43, 1246. doi:10.1021/jm990530+

415.Berkessel, A.; Andreae, M. R. M.; Schmickler, H.; Lex, J. Angew. Chem., Int. Ed. 2002, 41, 4481. doi:10.1002/1521-3773(20021202)41:23<4481::AID-ANIE4481>3.0.C O;2-7

416.Ayala, D. A.; Romero, J. M.; Jorge, N. L.; Gómez-Vara, M. E.; Jubert, A. H.; Castro, E. A. Spectrochim. Acta, Part A: Mol. Biomol. Spectrosc. 2006, 64, 717. doi:10.1016/j.saa.2005.06.046

417. Opsenica, D.; Pocsfalvi, G.; Juranić, Z.; Tinant, B.; Declercq, J.-P.; Kyle, D. E.; Milhous, W. K.; Šolaja, B. A. J. Med. Chem. 2000, 43, 3274. doi:10.1021/jm000952f

418. Opsenica, D.; Angelovski, G.; Pocsfalvi, G.; Juranić, Z.; Žižak, Ž.; Kyle, D.; Milhous, W. K.; Šolaja, B. A. Bioorg. Med. Chem. 2003, 11, 2761. doi:10.1016/S0968-0896(03)00224-4

419. Iskra, J.; Bonnet-Delpon, D.; Bégué, J. P. Tetrahedron Lett. 2003, 44, 6309. doi:10.1016/S0040-4039(03)01472-2

420.Žmitek, K.; Stavber, S.; Zupan, M.; Bonnet-Delpon, D.; Charneau, S.; Grellier, P.; Iskra, J. Bioorg. Med. Chem. 2006, 14, 7790. doi:10.1016/j.bmc.2006.07.069

421.Žmitek, K.; Stavber, S.; Zupan, M.; Bonnet-Delpon, D.; Iskra, J. Tetrahedron 2006, 62, 1479. doi:10.1016/j.tet.2005.11.022

422. Atheaya, H.; Khan, S. I.; Mamgain, R.; Rawat, D. S. Bioorg. Med. Chem. Lett. 2008, 18, 1446. doi:10.1016/j.bmcl.2007.12.069

423. Ghorai, P.; Dussault, P. H. Org. Lett. 2009, 11, 213. doi:10.1021/ol8023874

424. Terent'ev, A. O.; Kutkin, A. V.; Starikova, Z. A.; Antipin, M. Y.; Ogibin, Y. N.; Nikishin, G. I. Synthesis 2004, 2356. doi:10.1055/s-2004-831171

425. Terent'ev, A. O.; Kutkin, A. V.; Platonov, M. M.; Vorontsov, I. I.; Antipin, M. Y.; Ogibin, Y. N.; Nikishin, G. I. Russ. Chem. Bull. 2004, 53, 681. doi:10.1023/B:RUCB.0000035657.58776.cc

426.Kumar, N.; Khan, S. I.; Sharma, M.; Atheaya, H.; Rawat, D. S. Bioorg. Med. Chem. Lett. 2009, 19, 1675. doi:10.1016/j.bmcl.2009.01.103 
427. Kumar, N.; Khan, S. I.; Beena, R.; Rajalakshmi, G.; Kumaradhas, P.; Rawat, D. S. Bioorg. Med. Chem. 2009, 17, 5632.

doi:10.1016/j.bmc.2009.06.020

428. Terent'ev, A. O.; Borisov, D. A.; Chernyshev, V. V.; Nikishin, G. I.

J. Org. Chem. 2009, 74, 3335. doi:10.1021/jo900226b

429. Terent'ev, A. O.; Yaremenko, I. A.; Vil', V. A.; Moiseev, I. K.;

Kon'kov, S. A.; Dembitsky, V. M.; Levitsky, D. O.; Nikishin, G. I.

Org. Biomol. Chem. 2013, 11, 2613-2623. doi:10.1039/c3ob27239g

430. Kukovinets, O. S.; Zvereva, T. I.; Kabalnova, N. N.; Kasradze, V. G.; Salimova, E. V.; Khalitova, L. R.; Abdullin, M. I.; Spirikhin, L. V. Mendeleev Commun. 2009, 19, 106.

doi:10.1016/j.mencom.2009.03.019

431.Dong, Y.; Vennerstrom, J. L. J. Heterocycl. Chem. 2001, 38, 463. doi:10.1002/jhet.5570380224

432.Dong, Y.; Vennerstrom, J. L. J. Org. Chem. 1998, 63, 8582. doi:10.1021/jo981261i

433.Song, C. E.; Lim, J. S.; Kim, S. C.; Lee, K.-J.; Chi, D. Y. Chem. Commun. 2000, 2415. doi:10.1039/b005604i

434. Opsenica, D.; Pocsfalvi, G.; Milhous, W. K.; Šolaja, B. A. J. Serb. Chem. Soc. 2002, 67, 465. doi:10.2298/JSC0207465O

435. Terent'ev, A. O.; Kutkin, A. V.; Platonov, M. M.; Ogibin, Y. N.; Nikishin, G. I. Tetrahedron Lett. 2003, 44, 7359. doi:10.1016/S0040-4039(03)01844-6

436.Dubnikova, F.; Kosloff, R.; Almog, J.; Zeiri, Y.; Boese, R.; Itzhaky, H.; Alt, A.; Keinan, E. J. Am. Chem. Soc. 2005, 127, 1146. doi:10.1021/ja0464903

437. Opsenica, I.; Opsenica, D.; Smith, K. S.; Milhous, W. K.; Šolaja, B. A. J. Med. Chem. 2008, 51, 2261. doi:10.1021/jm701417a

\section{License and Terms}

This is an Open Access article under the terms of the Creative Commons Attribution License (http://creativecommons.org/licenses/by/2.0), which permits unrestricted use, distribution, and reproduction in any medium, provided the original work is properly cited.

The license is subject to the Beilstein Journal of Organic Chemistry terms and conditions:

(http://www.beilstein-journals.org/bjoc)

The definitive version of this article is the electronic one which can be found at: doi:10.3762/bjoc. 10.6 